\title{
Frazemi biblijskoga podrijetla u talijanskome i hrvatskome jeziku
}

\section{Mišetić, Damir}

\section{Doctoral thesis / Disertacija}

2021

Degree Grantor / Ustanova koja je dodijelila akademski / stručni stupanj: University of Zagreb, Faculty of Humanities and Social Sciences / Sveučilište u Zagrebu, Filozofski fakultet

https://doi.org/10.17234/diss.2021.8599

Permanent link / Trajna poveznica: https://urn.nsk.hr/urn:nbn:hr:131:802331

Rights / Prava: In copyright/Zaštićeno autorskim pravom.

Download date / Datum preuzimanja: 2023-04-26

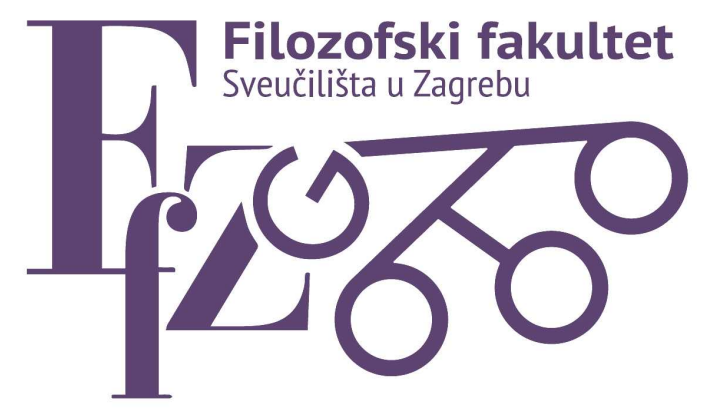

Repository / Repozitorij:

ODRAZ - open repository of the University of Zagreb Faculty of Humanities and Social Sciences
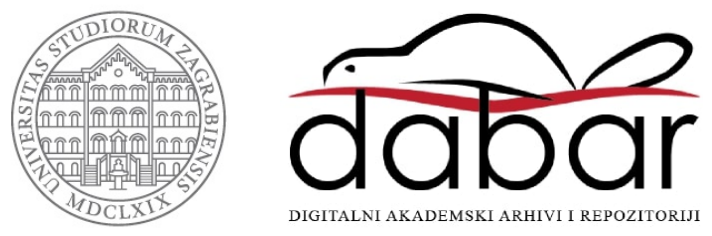


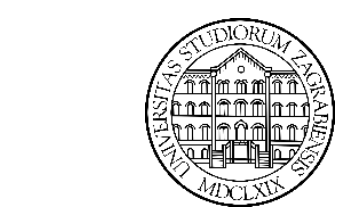

Sveučilište u Zagrebu

Filozofski fakultet

Damir Mišetić

\section{FRAZEMI BIBLIJSKOGA PODRIJETLA U TALIJANSKOME I HRVATSKOME JEZIKU}

DOKTORSKI RAD

Zagreb, 2021. 


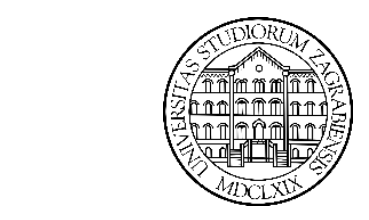

Sveučilište u Zagrebu

Filozofski fakultet

Damir Mišetić

\title{
FRAZEMI BIBLIJSKOGA PODRIJETLA U TALIJANSKOME I HRVATSKOME JEZIKU
}

\author{
DOKTORSKI RAD
}

\author{
Mentor: \\ prof. dr. Maslina Ljubičić
}

Zagreb, 2021. 


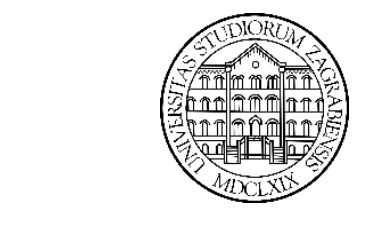

Sveučilište u Zagrebu

Faculty of Humanities and Social Sciences

Damir Mišetić

\title{
IDIOMS OF BIBLICAL ORIGIN IN ITALIAN AND CROATIAN LANGUAGE
}

\author{
DOCTORAL THESIS
}

Supervisor:

Professor Maslina Ljubičić, PhD

Zagreb, 2021. 


\section{O MENTORU}

Maslina Ljubičić rođena je 1955. godine u Splitu. Nakon završene zagrebačke Klasične gimnazije, na Filozofskome fakultetu Sveučilišta u Zagrebu diplomirala je talijanski i španjolski jezik i književnost, te kao paralelan studij engleski i francuski jezik i književnost. Bila je dobitnica Rektorove nagrade 1976. godine. Na istome fakultetu magistrirala je 1981., a doktorirala 1989. godine. Od 1980. zaposlena je na Katedri za talijanski jezik Odsjeka za talijanistiku Filozofskoga fakulteta Sveučilišta u Zagrebu, najprije kao asistent, od 1981. kao znanstveni asistent, od 1990. kao docent. Od 1994. do 1998. živjela je u Njemačkoj, dok joj je radni staž mirovao. U zvanje izvanrednoga profesora izabrana je 2000., od 2005. redoviti je profesor, a od 2011. redoviti profesor u trajnome zvanju. Pod njezinim je mentorstvom izrađeno osamdesetak diplomskih i završnih radova.

Bila je pročelnica Odsjeka za talijanistiku (2007. - 2009.), zamjenica pročelnika (1987. - 1989., 1999. - 2000., 2013. - 2017.) i predstojnica Katedre za talijanski jezik (1990. - 1994., 1999. - 2000. i 2011. - 2019.). U većem broju mandata bila je članica Fakultetskoga vijeća. Godine 2000. bila je koordinatorica poslijediplomskoga doktorskog studija lingvistike. Od 2005. do 2009. bila je član Vijeća područja društvenih i humanističkih znanosti Sveučilišta u Zagrebu. Od 2017. član je Matičnoga odbora za polje filologije Nacionalnoga vijeća za znanost, visoko obrazovanje i tehnološki razvoj, a od 2021. potpredsjednica je za znanost istoga Matičnog odbora.

Od 1990. sudjeluje u nastavi poslijediplomskoga studija lingvistike na Filozofskome fakultetu u Zagrebu, a od 2012. na Filozofskome fakultetu u Splitu. Osim mentorstava doktorskih disertacija u Zagrebu i Splitu, od 2014. do 2019. bila je mentorica pri pisanju disertacije iz talijanske leksikologije i frazeologije na Doktorskome studiju iz lingvistike Univerziteta u Sarajevu.

Neko je vrijeme sudjelovala u radu na Osmojezičnome rječniku Leksikografskoga zavoda "Miroslav Krleža" kao suradnica za talijanski jezik (god. 1993./94.). Godine 2000./01. bila je suradnicom na III. knjizi Hrvatske enciklopedije Leksikografskoga zavoda za područje talijanistike. Bila je recenzentica sveučilišnih i srednjoškolskih nastavnih programa, članaka u znanstvenim časopisima i zbornicima, sveučilišnih udžbenika i znanstvenih knjiga. 
Tiskane su joj dvije znanstvene knjige (Studije o prevođenju, 2000.; Posuđenice i lažni parovi. Hrvatski, talijanski i jezično posredovanje, 2011.) te jedna u digitalnome izdanju (ponovljeno izdanje druge knjige). U domaćim i stranim publikacijama objavila je preko 70 znanstvenih radova, a sudjelovala je s izlaganjima na stotinjak znanstvenih skupova.

Do 2002. godine surađivala je na znanstvenome projektu Hrvatsko-talijanske književne veze (voditelj Mate Zorić). Od 2002. do 2006. bila je voditeljica projekta MZOŠ Supostavna analiza hrvatskoga i talijanskoga jezika i konzultantica na projektu MZOS Jezici u kontaktu na području Istre i Dalmacije (voditeljica Smiljka Malinar), od 2007. do 2008. suradnica projekta Romanizmi u onomastici grada Splita (voditeljica Marina Marasović-Alujević) u okviru programa Studia Mediterranea (voditelj Joško Božanić), od 2007. do 2013. voditeljica projekta Talijanski i hrvatski u kontaktu i kontrastu u okviru programa Jezični i kulturni transferi kontakti i kontrastiranje (voditeljica Zrinjka Glovacki-Bernardi). Zatim je bila voditeljica istraživačkih institucijskih projekata Filozofskoga fakulteta Sveučilišta u Zagrebu (2013./2014. Talijanski i hrvatski varijeteti: dodiri i usporedba, 2015./2016. Usporedbe talijanskih i hrvatskih varijeteta u europskome kontekstu, 2017. Talijanski i hrvatski u kontaktu s drugim europskim jezicima, 2018. - 2020. Hrvatsko-talijanski jezični dodiri: standardni jezik i dijalekti). Od 2005. godine bila je suradnica međunarodnoga znanstvenog projekta Widespread Idioms in Europe and Beyond: A Cross-Linguistic and Cross-Cultural Research Project, a od 2016. Widespread Idiomatic and Formulaic Constructions (voditeljica Elisabeth Piirainen, Steinfurt, Njemačka). Od 2018. suradnica je projekta HRZZ Govori Makarskoga primorja - dijakronija i sinkronija (voditeljica Ivana Kurtović Budja).

Od 1987. član je uredništva časopisa Studia Romanica et Anglica Zagrabiensia, od 1987. do 1994. bila je tajnica uredništva, a od 2002. godine glavna je urednica.

U listopadu 1991. u Pisi dodijeljena joj je nagrada za promicanje talijanske kulture Premio Ascarelli zaklade Galileo Galilei dei Rotary Club Italiani.

Od znanstvenih udruga, članica je Hrvatskoga filološkoga društva, Associaçăo Internacional de Paremiologia / International Association of Paremiology (AIP-IAP) i Associazione Italiana di Fraseologia e Paremiologia (Phrasis). 


\section{SAŽETAK}

U ovome radu istražuju se i uspoređuju frazemi biblijskoga podrijetla u talijanskome i hrvatskome jeziku. Budući da spadaju u internacionalizme odnosno interfrazeologizme, frazemi biblijskoga podrijetla važna su skupina unutar frazeologije svakoga jezika. Kako potječu iz istoga izvora, iz Biblije ili Svetoga pisma, njihova raščlamba na međujezičnoj razini omogućuje bolje razumijevanje njihove dubinske strukture.

Premda talijanski i hrvatski nisu genetski srodni jezici, hrvatski jezik spada u Slavia Romana (Slavia Latina), pa je zbog toga, ali i zbog drugih razloga zamjetan utjecaj latinskoga na talijansku i hrvatsku frazeologiju, a u dvama jezicima uočava se i različita recepcija frazema biblijskoga podrijetla. Pripadanje istoj vjeroispovijesti i istoj obrednoj skupini bitno je utjecalo na frazeme biblijskoga podrijetla u obama jezicima: relativno velik broj potpunih jednakovrijednica u obama jezicima pokazuje snažan utjecaj tradicionalnoga Rimskog obreda u vjerskome, ali i kulturnome životu obaju naroda te privilegirano mjesto Vulgate, latinskoga prijevoda Biblije sv. Jeronima Dalmatinca. Manji broj djelomičnih jednakovrijednica u usporedbi s drugim supostavnim međujezičnim raščlambama također ide u prilog ovoj tezi. Velik broj primjera nulte ekvivalentnosti, odnosno nepostojanja jednakovrijednica zorno pokazuje kulturno-semantičku nepodudarnost između dvaju jezika i kultura, što pak svjedoči o Živosti recepcije biblijskih tekstova na svoj originalan način ne samo u substandardnim varijetetima hrvatskoga, nego i u standardnoj inačici gdje je frazeologija biblijskoga podrijetla osobito u prošlome stoljeću prolazila svoj „,dall'osanna al crucifigge“.

Ova sinkronijska supostavna raščlamba frazema biblijskoga podrijetla u talijanskome i hrvatskome jeziku pokazuje podudarnosti i razlike na strukturnoj, sintaktičkoj i semantičkoj razini te njihovu ekvivalentnost na međujezičnoj razini.

Ključne riječi: frazeologija; supostavna raščlamba; frazemi biblijskoga podrijetla; internacionalizmi; interfrazeologizmi; strukturna raščlamba; paradigmatičnost; varijantnost; semantička raščlamba; ekvivalentnost talijanskih i hrvatskih frazema. 


\section{SUMMARY}

This thesis deals with research and comparison of the idioms of biblical origin in the Italian and Croatian language. Since the biblical origin idioms belong to internationalisms, i.e. interphraseologisms, they represent an important group within the phraseology of each language. As they originate from the same source, i.e. from the Bible or the Holy Scripture, their analysis at interlingual level enables a better comprehension of their in-depth structure. Italian and Croatian are not genetically related languages, the Croatian language belongs to Slavia Romana (Slavia Latina), though, and for this as well as for other reasons there is a discernable influence of Latin on Italian and Croatian phraseology, respectively. However, different reception of the biblical origin idioms has been perceived in these two languages.

The theoretical framework of this thesis is a comparative phraseology. For this purpose phraseologically contrastive papers in the Croatian, German, Italian and Spanish language in general, and contrastive papers on the biblical origin idioms, in particular, were collected and studied. The corpus of this research are the idioms of biblical origin that we obtained by excerpting examples from Italian and Croatian phraseological dictionaries (monolingual, bilingual, printed and online). Methodology consisted of a contrastive analysis of excerpted idioms, where we mostly focused at the synchronic level bearing in mind that in each comparative analysis there is a diachronic aspect within sociocultural framework as well as an intercultural comparison. As the idioms are linguistic units established mainly secondarily, contrastive analysis uses particularly induction to describe these units derived from the units of the primary systems (vocabulary, syntax and morphology), and therefore it is always necessary to analyze the lexical, structural-syntactic and structural-semantic aspects. We also used a quantitative approach as much as possible and relevant in this study.

The aim of this contrastive analysis has been mainly to determine phraseological equivalents in both languages. We divided the equivalence into full, partial, purely semantic and zero, and possible idiomatic false friends were taken in consideration within this subsystem. This synchronous contrastive analysis of the idioms of biblical origin in the Italian and Croatian language indicates similarities and differences at the structural, syntactic and semantic levels, and their equivalence at interlingual level. This thesis represents the attempt to fill the gap in contrastive analysis of the idioms of biblical origin in the Italian and Croatian language and thus contribute to the development of comparative phraseology in general as well as to the 
research of the biblical origin idioms that have a strong influence in these two languages, both in the past and today, not only in standard language and in regional versions, but also in regional and local dialects.

The corpus of biblical idioms in Italian contains 209 examples, and 170 in Croatian, respectively. Contrastive analysis was approached from different points of view, using the methods of the Zagreb phraseological school and methods of phraseologists who write in German, as well. A relatively large number of idioms with full equivalence (80 examples) indicates most probably a strong influence of the same source, Latin translation of the Bible, i.e. Vulgata in both languages, as well as their belonging to the same religious denomination and ritual group, while does not confirm the results of numerous contrastive analyses of other microsystems in languages. The number of examples of partial equivalence, 45 in both corpora, differs from much contrastive analysis of phraseological microsystems of two or more languages. Equivalent idioms often exceed the number of congruent ones, but in regard to the aforementioned reasons such a distribution is not particularly surprising. There is only one example of purely semantic equivalence in which significant lexical and semantic differences are discernible, while the picture itself is different. Furthermore, both languages also have a significant number of idioms that have no equivalent in (that) other language, respectively: 83 idioms in Italian and 44 in Croatian. This indicates the cultural-semantic discrepancy in these two languages, different influences in the phraseological treasure, and the vitality of both languages, as well. In this way the power of the phraseology of small nations has been revealed, even in terms of the idioms that traditionally belong to internationalisms.

Strong influence and privileged place of Latin in the liturgy as well as in the culture and public life of both nations, had left the traces in phraseological treasure of both Italian and Croatian - in each of them in a special way - and marked other phraseological microsystems, in particular the idioms of biblical origin. And biblical origin idioms, whose stylistic values does not differ significantly, still today have a strong influence on the Croatian literary and spoken language, in its standard version, in all substandard varieties, as well, and significantly contribute to the peculiarity of the Croatian language, particularly from the point of view of speaker identification criteria. While this is not the case in Italian where there is a completely different dynamics in relation to other Romance languages. Perhaps only diachronic and areal phraseological research will shed some light on this richness and peculiarity of Croatian and its millennial tradition of using the idioms and paremias of biblical origin. This comparative analysis also shows all the complexity of the idioms regarding both expression and content, and 
their particularity. Certainly, we do not avoid reflecting on the need of structural language analysis at three abstract levels, i.e. the need for triple articulation in order to understand more seriously and explore more thoroughly the phraseology of European languages, but also to approach analytically more strictly to a more pronounced interest in the words connections that have been perceived in linguistics in recent decades.

Keywords: phraseology; contrastive analysis; idioms of biblical origin; internationalisms; interphraseologisms; structural analysis; paradigmaticity; variance; semantic analysis; equivalence of Italian and Croatian idioms. 


\section{SADRŽAJ}

1. UVOD 1

1.1. Cilj istraživanja

1.2. Ustrojstvo istraživanja

1.3. Važnost istraživanja za akademsku zajednicu

2. FRAZEOLOŠKA PROMIŠLJANJA 6

2.1. O frazeologiji kao (mladoj) jezikoslovnoj disciplini - teorijska promišljanja 6

2.2. Mjesto frazeologije unutar jezikoslovlja 13

2.3. Frazeologija u užemu i širemu smislu 20

2.4. Zadaće kontrastivne (poredbene) frazeologije 23

2.5. (Neprepoznata) važnost povijesne frazeologije 29

3. O POVIJESTI DOSADAŠNJIH ISTRAŽIVANJA

3.1. O povijesti istraživanja u Hrvatskoj 34

3.2. O povijesti istraživanja u Italiji 35

4. DEFINICIJA FRAZEMA 39

5. TEMELJNA OBILJEŽJA FRAZEMA

5.1. Polileksikalnost 50

5.2. Ustaljenost (stabilnost strukture, čvrstoća) 52

5.3. Idiomatičnost 56

5.4. Leksikaliziranost i reproduktivnost $\quad 60$

6. BIBLIJA - KNJIGA KOJA JE DUBOKO PROŽELA TALIJANSKU I 62 HRVATSKU KULTURU - NEPRESUŠAN IZVOR FRAZEMA 
6.2. Biblizmi kao internacionalizmi 76

6.3. Nastanak biblijskih frazema 82

6.3.1. Frazemi preuzeti izravno iz biblijskih tekstova 85

6.3.2. Frazemi nastali prevođenjem biblijskih tekstova 85

6.3.3. Frazemi nastali pod utjecajem biblijskih tekstova, ali nisu izravno 85 preuzeti iz njih

6.3.4. Frazemi nastali prema biblijskim predodžbama ili uzorcima, no bez 86 neposrednoga odnosa prema Novome ili Starome zavjetu

$\begin{array}{ll}\text { 7. METODOLOGIJA RADA } & 87\end{array}$

8. PREDSTAVLJANJE KORPUSA

9. STRUKTURNA RAŠČLAMBA FRAZEMA BIBLIJSKOGA 92 PODRIJETLA U TALIJANSKOME I HRVATSKOME JEZIKU

9.1. Fonetska riječ ili minimalni frazem 92

9.2. Sveza riječi 93

9.3. Frazemska rečenica 96

10. PARADIGMATIČNOST TALIJANSKIH I HRVATSKIH FRAZEMA 100 BIBLIJSKOGA PODRIJETLA

$\begin{array}{ll}\text { 10.1. Frazemi nulte paradigmatičnosti } & 101\end{array}$

10.2. Frazemi djelomične paradigmatičnosti 103

10.3. Frazemi potpune paradigmatičnosti 104

11. VARIJANTNOST TALIJANSKIH I HRVATSKIH FRAZEMA 106 BIBLIJSKOGA PODRIJETLA

11.1. Fonetske inačice 108 
$\begin{array}{ll}\text { 11.3. Sintaktičke inačice } & 109\end{array}$

11.4. Leksičke inačice 109

11.5. Leksičko-kvantitativne inačice 110

11.6. Kombinacija više vrsta inačica unutar jednoga frazema 111

12. SEMANTIČKA RAŠČLAMBA TALIJANSKIH I HRVATSKIH 116 FRAZEMA BIBLIJSKOGA PODRIJETLA

12.1. Načini čitanja frazema 117

12.1.1. Samo jedno čitanje $\quad 118$

12.1.2. Dva čitanja koja se jedno prema drugome odnose disjunktivno 118

12.1.3. Dva čitanja koja se ostvaruju, odnosno mogu ostvarivati istodobno 119

$\begin{array}{ll}\text { 12.1.4. Mješoviti tip } & 120\end{array}$

$\begin{array}{ll}\text { 12.2. Motiviranost frazema } & 121\end{array}$

12.2.1. Motiviranost na temelju značenja i mogućnost motiviranja $\quad 121$

$\begin{array}{ll}\text { 12.2.2. Remotiviranje ili ambigvitet } & 125\end{array}$

$\begin{array}{lr}\text { 12.3. Semantička autonomija sastavnica } & 127\end{array}$

$\begin{array}{ll}\text { 12.4. Semantičke značajke frazema } & 128\end{array}$

$\begin{array}{ll}\text { 12.4.1. Polisemija } & 129\end{array}$

$\begin{array}{ll}\text { 12.4.2. Sinonimija } & 130\end{array}$

12.4.3. Složenost 132

$\begin{array}{ll}\text { 12.4.4. Neodređenost } & 133\end{array}$

$\begin{array}{ll}\text { 12.4.5. Ekspresivnost } & 134\end{array}$ 

BIBLIJSKOGA PODRIJETLA

13.1. Pojam ekvivalentnosti

13.2. Razine međujezične usporedbe 138

13.2.1. Denotativno značenje

13.2.2. Doslovno značenje

13.2.3. Struktura

140

13.2.4. Stilska vrijednost

142

13.2.5. Zaključne napomene

13.3. Tipovi ekvivalentnosti

13.3.1. Potpuna ekvivalentnost

13.3.2. Djelomična ekvivalentnost

13.3.3. Čisto semantička ekvivalentnost

166

13.3.4. Nulta ekvivalentnost

166

13.4. Rezultati međujezične supostavne raščlambe frazema biblijskoga 180 podrijetla

14. ZAKLJUČNE NAPOMENE 


\section{UVOD}

\subsection{Cilj istraživanja}

Bavljenje supostavnom raščlambom frazema dvaju jezika jest bavljenje tematikom koja je, sudeći barem prema broju objavljenih radova o toj temi, iznimno zastupljena u suvremenim frazeološkim istraživanjima. Budući da frazeološke teme, osobito u germanističkim i slavističkim istraživanjima, predstavljaju vrlo živo područje istraživanja s pravom se može reći da frazeologija nipošto nije samo marginalna pojava u jezikoslovlju, nego se drži ,,središnjom granom suvremenoga jezikoslovnog istraživanja i nauka“ (Donalies 2009, § 1.).

U ovome radu istražuju se i uspoređuju frazemi biblijskoga podrijetla u talijanskome i hrvatskome jeziku. Budući da spadaju u internacionalizme odnosno interfrazeologizme, frazemi biblijskoga podrijetla važna su skupina unutar frazeologije svakoga jezika. Kako potječu iz istoga izvora, iz Biblije ili Svetoga pisma, njihova raščlamba na međujezičnoj razini omogućuje bolje razumijevanje njihove dubinske strukture.

Premda talijanski i hrvatski nisu genetski srodni jezici, hrvatski jezik spada u Slavia Romana (Slavia Latina), pa je zbog toga, ali i zbog drugih razloga zamjetan utjecaj latinskoga na hrvatsku kao i na talijansku frazeologiju, a u dvama jezicima uočava se i različita recepcija frazema biblijskoga podrijetla.

Cilj je ove sinkronijske supostavne raščlambe frazema biblijskoga podrijetla u talijanskome i hrvatskome jeziku odrediti podudarnosti i razlike na strukturnoj, sintaktičkoj i semantičkoj razini te njihovu jednakovrijednost na međujezičnoj razini.

\subsection{Ustrojstvo istraživanja}

Teorijski okvir ovoga rada jest komparativna (poredbena) ${ }^{1}$ frazeologija. U tu svrhu prikupljeni su i proučeni frazeološki kontrastivni radovi na hrvatskome, njemačkome, talijanskome i španjolskome jeziku općenito te posebice kontrastivni radovi o frazemima biblijskoga podrijetla.

Korpus ovoga istraživanja bit će frazemi biblijskoga podrijetla koje ćemo dobiti ekscerpiranjem primjera iz talijanskih i hrvatskih frazeoloških rječnika kao što su: Giuseppe

\footnotetext{
${ }^{1}$ Usp. $<$ http://struna.ihjj.hr/search-do/?q=poredbena+lingvistika\#container $>$ (15.1.2021.).
} 
Pittano, Dizionario dei modi di dire (2014); Paola Sorge, Dizionario dei modi di dire della lingua italiana (1997) te Antica Menac, Željka Fink-Arsovski, Radomir Venturin, Hrvatski frazeološki rječnik (Menac; Fink-Arsovski; Venturin 2014) te iz prikupljenih frazeoloških radova o spomenutoj temi.

Metodologija rada sastojat će se od supostavne analize ekscerpiranih frazema, pri čemu ćemo se uglavnom zadržati na sinkronijskoj razini, ne zaboravljajući pri tome da je u svakoj supostavnoj analizi prisutan i dijakronijski vid unutar sociokulturnoga okvira kao i interkulturalna usporedba.

Kako su frazemi jezične jedinice nastale uglavnom sekundarno, supostavna raščlamba služi se poglavito indukcijom kako bi opisala ove jedinice koje su nastale od jedinica primarnih sustava (leksika, sintakse i morfologije) te je stoga uvijek potrebno analizirati leksički aspekt, strukturno-sintaktički i strukturno-semantički. Koliko bude moguće i relevantno, pristupat će se kvantitativno.

Ne ćemo uzeti u obzir poslovice, u kojima je utjecaj Biblije u većini europskih jezika iznimno jak jer bi to iziskivalo zasebno istraživanje. Također ne ćemo proučavati ni mnogobrojne frazeme koji se odnose na kršćanstvo općenito, tzv. kristijanizme, na liturgiju ili papinstvo (primjerice tal. la fumata bianca - hrv. bijeli dim i sl.), nego ćemo istražiti frazeme kojima ishodište nalazimo u Starome i Novome zavjetu.

Rad će se sastojati od dvaju glavnih dijelova: prvoga teorijskog dijela (o frazeologiji, utjecaju Biblije na jezik, posebice frazeologije) te od raščlambe talijanskih i hrvatskih frazema biblijskoga podrijetla i zaključnoga dijela.

U teorijskome dijelu ponajprije ćemo nastojati produbiti dosadašnje teorijske spoznaje o frazeologiji, njezinu mjestu unutar jezikoslovlja te o frazeologiji u užemu i širemu smislu. Razmotrit ćemo i razvoj kontrastivne frazeologije te njezin doprinos jezikoslovlju i kulturi uopće. Spomenut ćemo i najnovije spoznaje i istraživanja s područja historijske frazeologije, osobito na njemačkome govornom području i naglasiti važnost upravo toga zapostavljenog dijela frazeologije. Pri tome ćemo poglavito slijediti pristup frazeologa njemačkoga govornog područja kao što su Harald Burger (2015) i njegovi suradnici.

Osvrnut ćemo se na dosadašnja istraživanja i spoznaje u Hrvatskoj. Pri tome ćemo uzeti u obzir spoznaje Zagrebačke frazeološke škole i radova Antice Menac (2007) i Željke FinkArsovski (2002) te kontrastivna istraživanja talijanskih i hrvatskih frazema, pri čemu ćemo se 
posebno osvrnuti na radove Josipa Jerneja (1996) i Masline Ljubičić (1994) kao i frazeološke radove jezikoslovaca na talijanskome govornom području (Casadei 1994).

Pri definiranju frazema polazit ćemo od već uvriježenih definicija na hrvatskome i proširiti ih saznanjima poznatih frazeologa njemačkoga govornog područja kao što je ponajprije Harald Burger (2015), čije ćemo radove uzeti kao polazište, te ostalih znamenitih frazeologa kao što su Wolfgang Fleischer (1997), Christine Palm (1997), Elke Donalies (2009), Elisabeth Piirainen (2012a) i drugi.

Osobito ćemo razmotriti temeljne značajke frazema kao što su polileksikalnost, ustaljenost i idiomatičnost te leksikaliziranost i reproduktivnost.

$\mathrm{Na}$ osnovi radova naših lingvista i bibličara naznačit ćemo utjecaj Biblije, Svetoga pisma Staroga i Novoga zavjeta na hrvatski jezik i književnost u okviru europskoga kulturnog kruga (Botica 1995).

Opisat ćemo specifičnosti frazema biblijskoga podrijetla kao internacionalizama. Pri tome ćemo iznositi rezultate istraživanja naših lingvista, primjerice Maje Opašić (2013), Marije Turk (1994), Ivane Vidović Bolt (2011) i frazeologa koji su pisali na njemačkome kao što su Czaba Földes (1990) i Elisabeth Piirainen (2012a) te španjolskih frazeologa kao primjerice Lucía Luque Nadal (2010) i Carmen Mellado Blanco (2017).

Osvrnut ćemo se na nastanak biblijskih frazema razlikujući četiri skupine: frazeme izravno preuzete iz biblijskih tekstova, frazeme nastale prevođenjem biblijskih tekstova, frazeme nastale pod utjecajem biblijskih tekstova koji nisu preuzeti izravno iz biblijskih tekstova te frazeme nastale prema biblijskim predodžbama i uzorcima, no bez neposredne veze sa Starim i Novim zavjetom.

U drugome dijelu disertacije, posvećenomu raščlambi talijanskih i hrvatskih biblijskih frazema, najprije ćemo predstaviti metodologiju rada, a potom i korpus koji ćemo sastaviti poglavito ekscerpiranjem iz talijanskih i hrvatskih frazeoloških rječnika, online frazeoloških rječnika, frazeoloških radova o ovoj temi te iz ostale građe koja nam bude na raspolaganju.

Do sada još nisu sustavno analizirani i uspoređeni talijanski i hrvatski biblijski frazemi, premda u obama jezicima predstavljaju važnu i zamjetnu skupinu frazema kojima je jedinstven izvor - Biblija ili Sveto pismo, što omogućuje dublji uvid u njihovo značenje i mjesto unutar suvremenoga talijanskog i hrvatskog jezika. 
Najprije ćemo analizirati strukturu talijanskih i hrvatskih biblijskih frazema i podijeliti ih na fonetske riječi ili minimalne frazeme, sveze riječi i frazemske rečenice prema načelima radova Antice Menac (2007).

Posvetit ćemo pozornost i paradigmatičnosti talijanskih i hrvatskih biblijskih frazema i podijeliti ih na frazeme nulte paradigmatičnosti, djelomične paradigmatičnosti i frazeme potpune paradigmatičnosti.

Glede varijantnosti talijanskih i hrvatskih frazema biblijskoga podrijetla razmotrit ćemo fonetske, tvorbene, leksičke i leksičko-kvantitativne inačice kao i kombinacije više inačica.

U semantičkoj raščlambi talijanskih i hrvatskih biblijskih frazema, polazeći od teorijskih spoznaja Haralda Burgera (2015), analizirat ćemo načine čitanja frazema: samo jedan način čitanja, dva načina čitanja koji se jedan prema drugome odnose disjunktivno, dva načina čitanja koji se mogu istodobno ostvarivati te mješoviti tip.

Posvetit ćemo pozornost motiviranosti frazema, remotiviranju, semantičkoj autonomiji sastavnica i semantičkim značajkama frazema kao što su polisemija, sinonimija, složenost, neodređenost i ekspresivnost.

Na kraju ćemo analizirati ekvivalentnost talijanskih i hrvatskih biblijskih frazema, što je ujedno i glavni cilj kontrastivne raščlambe.

U skladu sa spoznajama Haralda Burgera (2015) najprije ćemo se osvrnuti na pojam ekvivalentnosti te na razine međujezične supostavne analize: denotativno značenje, doslovno značenje, strukturu i stilsku vrijednost.

Potom ćemo razmotriti modele ekvivalentnosti i tipove ekvivalentnosti: potpunu, djelomičnu i nultu ekvivalentnost talijanskih i hrvatskih biblijskih frazema. U obzir ćemo uzeti i mogućnost čisto semantičke ekvivalentnosti.

U zaključnome dijelu sabrat ćemo rezultate spoznaja dobivenih supostavnom raščlambom talijanskih i hrvatskih biblijskih frazema i njihove podudarnosti, razlike i varijantnost. 


\subsection{Važnost istraživanja za akademsku zajednicu}

Očekuje se da će predloženo istraživanje pridonijeti upoznavanju talijanskih i hrvatskih frazema biblijskoga podrijetla, njihovu boljem razumijevanju unutar današnjega talijanskog i hrvatskog jezika jer kao internacionalizmi kojima je zajednički izvor Biblija pružaju osobitu mogućnost usporedbe tih dvaju jezičnih sustava, njihovih međusobnih utjecaja i kulturnih posebnosti. U frazemima jezik i kultura najuže su povezani i isprepleteni, što daje mogućnost uvida u duhovnu kulturu obaju naroda. Rezultati analize pridonijet će istraživanjima na području supostavne frazeologije, frazeografije, traduktologije, glotodidaktike i etnolingvistike. 


\section{FRAZEOLOŠKA PROMIŠLJANJA}

\subsection{O frazeologiji kao (mladoj) jezikoslovnoj disciplini - teorijska promišljanja}

Frazeologija je jezikoslovna disciplina koja se bavi frazemima. Riječ frazeologija potječe od grčke riječi $\varphi \rho \alpha ́ \delta \omega$ ('izložiti') e $\lambda o ́ \gamma o \varsigma$ ('riječ, govor'). Prema Hrvatskoj enciklopediji frazeologija je:

„1. Znanstvena disciplina (dio lingvistike) u kojoj se proučavaju i opisuju frazemi ili frazeologizmi, tj. ustaljeni višečlani izrazi u jeziku koji se u govoru reproduciraju kao cjelina i kod kojih značenje nije zbroj značenja pojedinih sastavnica, npr. jabuka razdora, baciti koplje u trnje, ići grlom u jagode, prevesti žedna preko vode i sl.

2. Način i tehnika izražavanja, odnosno strukturiranja teksta koji su svojstveni nekomu piscu.“2

No osim značenja znanosti koja proučava frazeološka sredstva jezika, frazeologija predstavlja i ,sveukupnost frazeoloških sredstava jezika“ (Menac 2007).

Njezino je značenje dakle dvostruko, slično kao i značenje riječi „gramatika“ koja predstavlja i „gramatiku jednoga jezika“ kao i znanost o tome (Burger 2015, 12).

Na to upozorava i Vidović Bolt koja kaže: „Sam je naziv frazeologija (grč. phrásis: 'izraz' + lógos: 'riječ, govor') prije svega poliseman jer označuje samostalnu jezikoslovnu disciplinu koja unutar jednoga ili više jezika proučava jezične jedinice, frazeme, koje karakterizira čvrsta struktura“ $(2011,13)$. Međutim, uz to značenje istodobno se tim istim pojmom nazivaju i ,jedinice jednoga jezika koje čine zasebnu cjelovitu podskupinu frazeologije, pa je tako moguće razlikovati zoonimsku frazeologiju, somatsku frazeologiju; nacionalnu, internacionalnu; regionalnu, dijalektnu frazeologiju; frazeologiju nekog pisca itd. (Fink 2002, 5; Lewicki i Pajdzińska 2001, 315)“ (isto).

I sam naziv frazeologija nedvojbeno je i u romanskome, slavenskome i germanskome jezikoslovlju najbolje prihvaćen od svih drugih pojmova, tako da primjerice i u talijanskome (fraseologia), hrvatskome (frazeologija), njemačkome (Phraseologie), francuskome

\footnotetext{
${ }^{2}<$ http://www.enciklopedija.hr/Natuknica.aspx?ID=20523> (24.8.2018.).
} 
(phraséologie) i španjolskome (fraseologia) isti pojam vrlo jasno određuje gore spomenuta značenja.

Glede zadaća frazeologije postoje različita mišljenja koja se uglavnom nadopunjuju jer se frazeologiji pristupa s različitih stajališta i sve više interdisciplinarno, a težište se stavlja uglavnom na ono što se proučava.

Prema Mokienku (2009a, 793) zadaće frazeologije jesu: „određivanje kategorijalnih značajki ustaljenih sveza riječi, istraživanje frazeološkoga blaga jednoga jezika kao sustava te unutarnjih zakonitosti njihova razvoja i njihova funkcioniranja te $\mathrm{k}$ tome omeđivanje discipline frazeologije, klasifikacija različitih tipova frazema, određivanja njihovih semantičkih, gramatičkih, funkcionalno-semantičkih i stilskih karatkeristika““ ${ }^{3}$ Predmet frazeologije prema tome je ,istraživanje čvrstih sveza riječi određenih jezika u usporedbi s drugim jezicima, utvrđivanje kulturološkoga fonda i nacionalne specifičnosti frazeoloških jedinica, način stvaranja frazeoloških jedinica, raščlamba povijesti i etimologije frazema“ (isto).

Prema Ruiz Gurillo (1997, § 1.) frazeologija je oduvijek bila „ničija zemlja“, a tijekom stoljeća jedini doprinos njezinoj raščlambi sastojao se u „općim i posebnim leksikografskim zbirkama“" (isto).

Premda su filozofi i učenjaci još od klasične starine zamjećivali te djelomično i proučavali pojave kojima se danas bavi frazeologija, od humanizma počinje ozbiljnije proučavanje i prikupljanje izreka i poslovica (usp. Ruiz Gurillo 1997, § 1.).

U šesnaestome je stoljeću već „u raznim europskim zemljama otpočelo prikupljanje narodnih uzrečica i izreka svih vrsta, kao i citata iz djela značajnih autora“ (Matešić 1978, 211).

Međutim, početke frazeologije kao jezikoslovne discipline u modernome smislu riječi smješta se tek na početak prošloga stoljeća.

Švicarski strukturalist Charles Bally još davne 1909. godine objavljuje djelo Traité de stylistique française, čime je udario temelje za istraživanje frazeoloških fenomena. Bally nastavlja s produbljivanjem ,malobrojnih, ali fundamentalnih izjava svoga učitelja Ferdinanda de Saussurea“ (Burger 2005, 20).

\footnotetext{
${ }^{3}$ Navode iz knjiga na njemačkome jeziku, a nešto manje i na talijanskome i španjolskome preveo je autor disertacije.
} 
Bally daje prve definicije koje se kasnije produbljuju, primjerice govoreći o unité phraséologique napominje da ,un groupe forme une unité lorsque les mots que le composent perdent toute signification et que l'ensemble seul en a une; il faut en outre que cette signification soit nouvelle et n'équivale pas simplement à la somme des significations des éléments“ (Bally 1909, 74). Navodi primjerice i prve upute kako prepoznati frazem i dijeli ih na ,indices extérieurs et intérieurs“(Bally 1909, 75).

Bally je već, iako ne sustavno, opažao mnoštvo kriterija kako bi se svezu riječi moglo prepoznati kao frazeološku, primjerice: grafički rastavljene sastavnice, nepromjenjiv redoslijed sastavnica, nemogućnost stranih elemenata da prodru u sastavnice, ${ }^{4}$ značenje sastavnica koje nije svjesno (oubli), ${ }^{5}$ postojanje arhaizama u izrazima ${ }^{6}$ itd. (usp. Burger 2005, 23).

Ballyjevo djelo pisano je jasnim i razumljivim jezikom i zanimljivo je za čitanje i vrlo korisno za produbljivanje znanja o frazeologiji te po našoj prosudbi zaslužuje da ga se više spominje i istražuje nego što se to dosad u našemu jezikoslovlju činilo.

Njegova istraživanja pak nisu dugo imala odjeka ni u romanističkome, a ni u germanističkome jezikoslovlju.

Međutim, tim je svojim djelom stvorio „konceptualnu okosnicu“ (Burger 2015, 9) za istraživanje frazeoloških fenomena i time položio kamen temeljac lingvističkoj disciplini koja je doživjela procvat poglavito nastankom i širenjem strukturalizma ponajprije u bivšemu Sovjetskom Savezu te potom počevši od sedamdesetih godina prošloga stoljeća i u germanističkim jezikoslovnim istraživanjima. Danas frazeologija spada u najistraživaniji dio jezika posebice u slavističkim i germanističkim istraživanjima, što se pak ne može reći za romanistička, osim djelomično za hispanistiku, iako je u posljednjih nekoliko godina zamjetan sve veći interes za frazeološka istraživanja i u romanistici.

\footnotetext{
$\left.{ }^{4}, 1\right)$ que un groupe est composé de plusieurs mots séparés par l'écriture, 2) que ces mots sont disposés dans un ordre invariable et ne peuvent pas être séparés par d'autres mots, 3) qu'aucun des mots du groupe ne peut être remplacé par un autre mot" (Bally 1909, 75).

5 „Quoi qu'il en soit, de nombreux indices prouvent que les articulations que relient les éléments d'un groupe ne sont plus saisies par la conscience, et que ces éléments eux-mêmes ne sont plus 'pensés', les rouages sont encrassés, si l'on peut dire. Ces indices ne permettent pas de découvrir toutes les unités phraséologiques, mais ils s'appliquent à l'immense majorité d'entre elles ; ils montrent invariablement que l'esprit du sujet parlant est préoccupé de relier la locution totale à l'idée dont elle est le symbole, et que cette correspondance lui fait oublier la valeur des éléments isolés. Dans tous ces cas, il y a, d'une manière quelconque incompréhension et oubli“" (Bally 1909, 78 - 79).

${ }^{6}$ „Un indice important de groupement phraséologique, c'est la présance d'un archaïsme dans une expression“ (Bally 1909, 80).
} 
U tridesetim i četrdesetim godinama 20. stoljeća ruski jezikoslovci počinju istraživati frazeološke fenomene, a od pedesetih do sedamdesetih godina 20. stoljeća nastavljajući rusku tradiciju Viktor V. Vinogradov, kojemu je Ballyjeva teorija poslužila kao „teorijska odskočna daska“ (Mokienko 2009b, 807), produbljuje istraživanja i bitno pridonosi osamostaljivanju frazeologije kao samostalne jezikoslovne discipline neovisne o leksikologiji. ${ }^{7}$ Otad frazeologija doživljava pravi procvat, što se može vidjeti po brojnim publikacijama posvećenima toj temi.

Burger $(2005,24)$ navodi podjelu ruskih frazeoloških istraživanja na tri dijela koju su predložili Dobrovol'skij i Filipenko:

1. Klasično razdoblje od otprilike 1940. - 1980. koje je obilježeno Vinogradovljevim radovima i koje se bavilo definicijom frazeologije i klasifikacijom frazema.

2. Drugo bi usmjerenje bilo povezano s Mel'ćukom i njegovom teorijom „leksičkih funkcija“ koje je nastalo šezdesetih godina i koje je do danas aktualno.

3. Od osamdesetih godina razvija se treći pravac „koji je obilježen jakim kognitivnim i etnokulturnim usmjerenjem“ (Burger 2005, 24).

Prvi radovi posvećeni frazeologiji njemačkoga jezika objavljuju se koncem šezdesetih godina 20. stoljeća. Razvoj njemačke frazeologije „nezamisliv je bez puno ranijih radova švicarskoga strukturalista Charlesa Ballyja“ (Burger 2005, 20).

Ujedno, germanistička frazeologija u sedamdesetima nastala je pod utjecajem „klasičnih radova ruske frazeologije i mogla je graditi dalje na teorijskim konceptima koji su u njoj stvoreni“ (Burger 2005, 24). Jasno je da je frazeologija ondašnjega DDR-a bila u „stalnome doticaju sa sovjetskim istraživanjima“" (isto).

Prvi sustavan prikaz njemačke frazeologije dala je sovjetska lingvistica Irina I. Černyševa 1970. godine. U sedamdesetim godinama počinju objavljivati brojni njemački jezikoslovci kao primjerice Burger (1973), Rothkegel (1973) i Häusermann (1977). Godine 1982. u Zürichu Harald Burger, Annelies Buhofer i Ambros Sialm objavili su djelo Handbuch der Phraseologie. U tim djelima ne istražuje se samo frazeologija njemačkoga jezika, nego se rješavaju mnoga pitanja od opće važnosti za frazeologiju uopće.

\footnotetext{
${ }^{7}$ Premda oko toga ne postoji opće suglasje u znanosti. Više o tome u poglavlju 2.2.
} 
Wolfgang Fleischer objavio je najprije 1982. godine monografiju Phraseologie der deutschen Gegenwartssprache, a potom 1997. godine neznatno izmijenjeno izdanje istoga djela i može se reći da ono predstavlja prikaz frazeoloških istraživanja u bivšemu DDR-u. Doprinos frazeologiji dali su svojim monografijama i Christine Palm (1997), Elke Donalies (2009) i Elisabeth Piirainen (2012a; 2016).

Godine 2007. Harald Burger (Zürich) u suradnji s Dmitrijem Dobrovol'skijem (Moskva), Peterom Kühnom (Trier) i Nealom R. Norrickom (Saarland) izdao je knjigu Phraseologie koja predstavlja najbolji prikaz suvremenih frazeoloških istraživanja. Harald Burger sa suradnicima tiskao je 2012. godine knjigu Aspekte der historischen Phraseologie und Phraseographie, posvećenu povijesnoj frazeologiji i frazeografiji i njezinoj važnosti, a 2015. izdao je četvrto, dopunjeno izdanje knjige Phraseologie - Eine Einführung am Beispiel des Deutschen, koja daje odgovore na temeljna pitanja frazeologije, rješava nedoumice oko terminologije i prikazuje rezultate najnovijih istraživanja. Premda su primjeri uzeti uglavnom iz njemačkoga jezika, objašnjenja nisu ograničena samo na jedan jezik te se mogu primijeniti u frazeološkim istraživanjima drugih jezika.

Glede istraživanja frazeologije romanskih jezika, što mnogi jezikoslovci drže ključnim za napredak i produbljenje spoznaja na području frazeologije europskih jezika i frazeoloških istraživanja uopće, unutar frazeologije njemačkoga govornog područja možemo spomenuti Thuna (1978) koji se služio spoznajama dobivenim iz sovjetskih frazeoloških istraživanja i to na temelju Coseriuove jezične teorije (usp. Burger 2005, 19).

Gréciano je djelomično na francuskome, ali na njemačkome jezičnom materijalu (usp. Burger 2005, 19) uvela promišljanja ondašnje germanističke frazeologije u romanističko jezikoslovlje, a Zuluaga (1980) je također na temelju tih spoznaja razvio autentičnu hispanističku frazeologiju.

U posljednjim desetljećima frazeologiji se pristupa na različite načine i sve je više zamjetno zanimanje za ustaljene sveze riječi s različitih stajališta i uz primjenu različitih metodoloških pristupa. Upravo je interdisciplinarni pristup frazeologiji potaknuo nevjerojatno brz rast te lingvističke discipline. Stoga u moru novih radova i istraživanja nije lako prepoznati i opisati prevladavajuće tendencije. Međutim, ipak se daju jasno prepoznati neki naglasci. 
Frazeologiji se danas uz sistemsku lingvistiku pristupa sa stajališta lingvističke geografije, pragmalingvistike, lingvistike tekstnih vrsta, pedagoško-didaktički, translatološki (usp. Chrissou 2000, 10).

„Otprilike 15 godina nakon konsolidacije frazeološko istraživanje rascjepkalo se u različitim vidovima. Jednojezični pristupi nadopunjuju se kontrastivnima, pojava frazeoloških jedinica u tekstovima i u određenim tekstnim vrstama sve se više promatra pod vidom uporabe, frazeološka leksikografija (frazeografija) sve češće ide vlastitim putovima, jezičnodidaktička pitanja posebno se obrađuju (frazeodidaktika). Osim toga, sve se više pojavljuju specijalizirana istraživanja o posebnim skupinama frazeologije. Lavovski dio ovih istraživanja imaju za predmet istraživanja 'rutinske formule' odnosno 'pragmatičke frazeme'. Ovi tematski kompleksi obilježavaju frazeološka istraživanja danas“(Chrissou 2000, 10).

Osim toga, u posljednjih nekoliko godina sve je više zamjetan interes za odnos frazeologije i kulture, premda je taj dio i ranije bio zanimljiv, ali mu se uglavnom danas drukčije pristupa zahvaljujući brojnim istraživanjima koja su prethodila od pojave frazeologije u modernome smislu riječi u prošlome stoljeću.

U svezi s time Piirainen $(2012 b, 167)$ ističe: „Dvije spoznaje sve su se više nametnule u novijim istraživanjima idioma: s jedne strane kultura predstavlja jednu od temeljnih konstanti idioma. S druge strane idiomi se u jednome jeziku počesto ne pojavljuju izolirano, nego u surječju europskih jezika koje je veće nego što se ranije vjerovalo“. Međutim, s obzirom na istraživanja koja ne uzimaju u obzir ova postignuća u frazeologiji vidi određenu diskrepanciju između spoznaja i njihova ostvarivanja u praksi te zaključuje: „Za obuhvatniji opis strukture, semantike i pragmatike jednoga idioma neizostavno je promatranje kulturnoga okružja, povijesti i etimologije idioma te usmjerenost prema paralelama u drugim jezicima“" (isto). Na tu činjenicu upućuje također i Meisinger $(1997,61)$ koji naglašava da je frazeologija ,pouzdan pokazatelj inherentne duhovne homogenosti neke zajednice“.

Na drugoj pak strani, nakon početnoga približavanja, a onda udaljavanja, gramatička teorija i frazeološka istraživanja sve se više približuju. U duhu optimalnosne teorije mnogi prepoznaju da se i u naoko, ,iregularnim“ područjima ljudskoga jezika, što je bio uglavnom i razlog udaljavanja gramatičke teorije i frazeologije, prepoznaje uređujuća snaga gramatičkoga sustava (usp. Müller 1997). 
I doista, $\mathrm{u}$ istraživanjima binoma primjerice i njihova slijeda sastavnica nije lako formulirati jasna pravila. Govorimo li o ograničenjima u duhu optimalnosne teorije, a ne o pravilima, jasnije se prepoznaje ta uređujuća snaga gramatičkoga sustava i očito je da frazeologija nije toliko „iregularna“ koliko se mislilo. Ograničenja po svojoj definiciji jesu prekršiva, međutim unatoč prekršivosti, u slijedu binoma primjerice prepoznajemo i jasne tendencije i preferencije (usp. Mišetić 2018).

O stavu mnogih jezikoslovaca da je frazeologija na periferiji jezika govori i Ruiz Gurillo: „Una buena parte de los lingüistas se ha referido a la fraseología de una y otra manera como fenómeno de lengua, aunque marginal, resaltando fundamentalmente que se trata de unidades complejas irregulares que no responden a los procesos sistemáticos presentes en otras unidades de lengua“" (1997, § 3. 1.).

Müller (1997, 2) vjeruje da se razvojem optimalnosne teorije koju su razvili Alan Prince, Paul Smolensky, John McCarthy i drugi javlja ,gramatička teorija u kojoj prekršiva ograničenja nisu marginalna iznimka, nego norma i pod ovim vidom postavlja se iznovice problem interakcije frazeoloških istraživanja i gramatičke teorije, po našemu uvjerenju, s boljim izgledom rješenja“.

Za proučavanje frazeologije koja nije na rubovima jezika zalagala se već i spomenuta Ruiz Gurillo koja, pozivajući se na druge jezikoslovce, kaže da je posrijedi „un fenómeno con sus propias reglas“ (1997, § 3.1.).

U frazeologiji se danas, iako „sporo“ (Hallsteinsdóttir; Farø 2006), probija svijest da su frazemi posvema normalne leksičke jedinice. Frazemi se uglavnom ponašaju kao „normalne sintaktičke tvorbe“ (Burger 1997). Počesto se olako govori o morfosintaktičkim anomalijama kao bitnim obilježjima frazema, iako su frazemi ,uglavnom sintaktički normalni. Samo za jako malo frazema vrijedi gore spomenuta okamenjenost: fleksija je zapravo u krajnje rijetkim izuzetcima odista smrznuta“ (Donalies 2009, 18 - 19). Ta spoznaja zahtijeva novi pristup frazemima koji će u nekim stvarima probiti granice tradicionalne frazeologije, što svakako može dovesti i do potrebe za novim definiranjem pojmova. Neki frazeolozi zalažu se za „holističko-integrativni pristup“ (Hallsteinsdóttir; Farø 2006), prema kojemu se bolje mogu proučiti odnosi frazema prema ostalim jezičnim znakovima.

Na taj način frazeološka istraživanja bila bi tim više prožeta strožom znanstvenom metodologijom i interdisciplinarnošću, a sve moderne spoznaje iz drugih jezikoslovnih 
disciplina ugradile bi se u potpunosti u frazeologiju i frazeologija bi se jasnije razlikovala od folklorističkoga, etnološkoga pa i filološkoga te ostalih pristupa s kojima bi se nadopunjavala gdje god je to moguće i potrebno.

U germanističkome pa i slavističkome jezikoslovlju može se jasno vidjeti da je frazeologija dostigla visok stupanj znanstvenosti i interdisciplinarnosti. Romanistika, nažalost, prilično je udaljena od toga ideala. Međutim, za dublje i bolje razumijevanje hrvatske nacionalne frazeologije nužne su supostavne raščlambe poglavito s talijanskim, ali i drugim romanskim jezicima. Dobar dio Hrvatima nastanjenih krajeva u Hrvatskoj, Bosni i Hercegovini i Crnoj Gori prema klasičnim podjelama spada u „Romania submersa“ (usp. Renzi; Andreose 2003, 32), u ,izgubljenu i potonulu“ Romaniju. Premda nam je jasno da puno toga i nije „potonulo“, 8 još je jasnije da utjecaji romanskoga supstrata zacijelo najduže ostaju na području frazeologije i uvjereni smo da će istraživanja na tome području biti svakako plodna i obogaćujuća i za naše, ali i za romansko jezikoslovlje uopće.

\subsection{Mjesto frazeologije unutar jezikoslovlja}

Premda se već duže vremena raspravlja o tome je li frazeologija posebna jezikoslovna disciplina ili je dijelom leksikologije, ne može se reći da je na to pitanje odgovoreno na zadovoljavajući način i da je rasprava okončana. Situacija je iz godine u godinu sve složenija jer se frazeologiji danas, kako smo već gore spomenuli, pristupa interdisciplinarno i proučava je se s različitih stajališta. Dok se nekim frazeolozima čini da je ipak bolje frazeologiju promatrati dijelom leksikologije, drugi pak na temelju najnovijih istraživanja jasno prepoznaju posebno mjesto frazeologije unutar jezikoslovlja.

Već je 1931. godine Evgenij Dmitrijevič Polivanov zahtijevao frazeologiju kao zasebnu disciplinu koja bi se prema opsegu i zadaći izjednačila sa sintaksom. Trebala bi istraživati značenje sveza riječi kao što leksikologija istražuje značenje riječi (Polivanov 1931, 119 prema Fleischer 1997, 9).

\footnotetext{
${ }^{8} \mathrm{~S}$ tim u svezi zanimljiva su istraživanja Radoslava Katičića o utjecaju latinskoga i talijanskoga jezika na grad Zagreb gdje se „u gradskim spisima susreće njemački, očito je taj jezik u gradskoj općini bio važan, ali se u pismenoj porabi mnogo više rabi latinski. I kako protječe vrijeme to ostaje tako. Povezuje se to s činjenicom što su u Zagrebu pored njemačkih doseljenika ne manje važni bili i talijanski. Napokon, znamo da je u Zagrebu jedan potomak Danteova roda bio ljekarnik. Prisutnost talijanskog elementa, kakve u Varaždinu nije bilo, podupirala je u službenim zapisima o zagrebačkim gradskim poslovima latinski protiv njemačkoga“ $(1999,40)$.
} 
U ruskome jezikoslovlju, zahvaljujući poglavito istraživanjima V. V. Vinogradova frazeologija se odvaja od leksikologije i drži se samostalnom jezikoslovnom disciplinom. No rasprave o tome još su dugo potrajale.

Začuđujuće je stoga da je „1967. godine upravo sovjetski jezikoslovac A. V. Kunin na 10. međunarodnome kongresu jezikoslovaca u Bukureštu izjavio da frazeologija kao grana opće lingvistike praktično još ne postoji“ (Pilz 1981, 47) premda je po broju objavljenih publikacija posvećenih frazeologiji sovjetsko jezikoslovlje tada bilo vodeće u svijetu.

Veliki broj daljnjih istraživanja i publikacija doveo je do toga da se to ipak ne može više tako lako izjaviti.

Nakon desetljećā intenzivnoga istraživanja i velikoga broja objavljenih radova o frazeološkim temama 1972. godine V. Archangel'skij (1972 prema Fleischer 1997, 9) piše: „Frazeologija je samostalna jezikoslovna disciplina koja obuhvaća sve tipove stabilnih interno određenih kombinacija skupova riječi koji postoje u jeziku i djeluju u govoru nositelja jezika“.

Pod utjecajem sovjetske frazeologije osobito se u rusistici u bivšemu DDR-u zastupalo mišljenje da je frazeologija disciplina neovisna od leksikologije. Stoga R. Eckert (1976 prema Pilz 1981, 47) ustvrđuje da se „frazeologija sve više oslobađa od vrhovništva leksikologije jer je reflektiranje društvenih pojava u frazeologiji još jače izraženo nego u leksikologiji“.

Sabitova (1976 prema Pilz 1981, 48) u svojoj disertaciji konstatira:

„Frazeologija je samostalna poddsiciplina unutar jezikoslovlja koja ima svoju vlastitu povijest nastanka i razvoja, svoj predmet proučavanja, svoje zadaće i metode opisa i istraživanja. Kao samostalna poddisciplina jezikoslovlja predstavlja poseban sloj u jezičnoj strukturi pri čemu se opaža uzajamno prožimanje leksika i sintakse“. Ona toj jezikoslovnoj poddisciplini dodjeljuje „određeni položaj posrednika između leksikologije i gramatike“ (isto).

Nasuprot tomu se $\mathrm{u}$ germanističkim radovima na njemačkome smatralo da je „frazeologija još dijelom leksikologije“ (Fleischer 1997, 10).

I u domaćoj jezikoslovnoj literaturi ,prisutno je različito viđenje frazeologije kao jezikoslovne discipline. Ona se najčešće prikazuje kao samostalna jezikoslovna disciplina (Samardžija 1995, 84) ili kao relativno samostalna jezikoslovna disciplina u vrlo bliskoj vezi s leksikologijom (Melvinger 1989, 84; Hudaček-Mihaljević-Pilić 2001, 86)“ (Kovačević 2012, $3)$. 
Tafra $(1996,73)$ drži da mnogi leksikologiju „shvaćaju preširoko pa u nju ubrajaju sva ona jezikoslovna područja koja imaju riječ za predmet istraživanja, međutim konstatira da su se ta područja „,već toliko osamostalila da se danas s pravom smatraju zasebnim jezikoslovnim disciplinama, kao što su etimologija, terminologija, onomastika, frazeologija, tvorba“ (isto).

Fink-Arsovski drži da je zahvaljujući burnomu razvoju koji je otpočeo na području bivšega Sovjetskog Saveza te brojnim frazeološkim radovima i rječnicima frazeologija „dokazala opravdanost svoga osamostaljenja“ (2002, § 1.1.).

Prema Christine Palm frazeologija je ,,poddisciplina leksikologije, ili ako tako hoćemo i samostalna jezikoslovna disciplina“" (1997, XI).

Prema Kühnu frazeologija danas „,kao samostalna znanstvena disciplina pripada kanonu njemačkih jezikoslovnih istraživanja“"(2007).

Zbog gotovo nepostojeće literature na talijanskome, ne možemo navesti stav o ovome $u$ talijanskome jezikoslovlju.

U drugim su pak romanskim jezicima frazeološka istraživanja i promišljanja imala snažniji odjek nego u talijanskome. Tako primjerice španjolska lingvistica Ruiz Gurillo (1997, 26) drži da mišljenja nisu jedinstvena i da neki zastupaju veze između leksikologije i frazeologije ili pak između sintakse i frazeologije: „To pokazuje, po našoj prosudbi, obilježje frazeologije kao granične kategorije smještene između leksikologije i sintakse“.

Elke Donalies $(2009,5)$ napominje da su se u početku frazeološki fenomeni „obrađivali u stilistici ili leksikologiji“, ali da se frazeologija „etablirala kao samostalna grana jezikoslovlja“ (isto), no dodaje da ,'etabliranje frazeologije ide u korak sa stalnim proširenjem njezinoga područja istraživanja' - što opet dovodi do toga da se frazeolozi danas pitaju 'prisiljava li takvo širenje da se napusti jedinstvo ove jezikoslovne poddiscipline i [...] prepusti općim područjima kao leksikologiji, analizi konverzacije i tekstnoj lingvistici' (Böhmer 1997, 1)“(Donalies 2009, 6).

Mjesto frazeologije unutar jezikoslovlja ne dobiva prikladan odgovor poglavito zbog „složenoga karaktera istraživanoga jezičnog fenomena“" (Chrissou 2000, 14), na što je upozorio i Mokienko (2009a, 793): „Ove rasprave uvjetovane su činjenicom da je frazeologija dio jezičnoga sustava koji nastaje zajedničkim djelovanjem jedinica različnih razina. Budući da je 
jedna od njezinih specifičnih značajki, stabilnost, svojevrstan 'konzervativizam', ona čuva značajke onih jezičnih razina od kojih je potekla i koje i dalje utječu na njezino funkcioniranje“.

Pridodamo li tomu da frazeološka istraživanja na engleskome jeziku idu svojim vlastitim putovima i da se terminologija, ali i metode bitno razlikuju, jasno je da sve to dodatno usložnjava problematiku.

Teško je predvidjeti kojim će putovima krenuti frazeologija u Italiji. Zasad je uz nekadašnji utjecaj sovjetske lingvistike osobito na lingviste španjolskoga govornog područja zamjetan utjecaj njemačke frazeološke škole.

Rječnik Španjolske kraljevske akademije (DRAE) pod brojem 5. definicije frazeologije navodi da je frazeologija dijelom jezikoslovlja „Parte de la lingüística que estudia las frases, los refranes, los modismos, los proverbios y otras unidades de sintaxis total o parcialmente fija". ${ }^{9}$ Uopće se ne spominje odnos prema leksikologiji, što znači da se drži samostalnom jezikoslovnom disciplinom usporedivom s drugima.

Međutim, u literaturi je i danas prošireno uvjerenje da „frazeologija uz tvorbu riječi predstavlja poddisciplinu leksikologije. U skladu $\mathrm{s}$ tim shvaćanjem tvorba riječi i frazeologizacija jesu postupci koji služe tvorbi jedinica nominacije i proširenju leksikona. Polazi se od leksemskoga karaktera i imenujuće (nominativne) funkcije frazema i konstrukcija tvorbe riječi“" (Chrissou 2000, 14).

Stoga se Chrissou priključuje tomu shvaćanju jer ,po tome načinu promatranja ne postoji razlog da se frazeologiju promatra odvojenom od leksikologije. Kao poddisciplina leksikologije frazeologija ima zadaću istraživati semantičke, sintaktičke i funkcionalne značajke frazema u sustavu i tekstu“ $(2000,15)$.

Usuprot tome, Marcel Dräger baveći se važnošću historijske frazeologije i promatranjem frazema u dijakronijskoj perspektivi zaključuje: „Čini mi se prikladnim da se frazeologiju kao posebnu razinu jezika ne samo jasno odvoji od leksikologije i drugih područja, nego da se istakne posebna uloga frazema koji su najčešće već i na temelju svoje ikoničnosti i polileksikalnosti više od svih drugih jezičnih elemenata obilježeni svojim razvojem i poviješću, također i u području jezične mijene“ (Dräger 2012, 206).

\footnotetext{
${ }^{9}<$ http://dle.rae.es/?id=IPoTKej> (8.9.2018.).
} 
Osim s leksikologijom kako smo i vidjeli, frazeologija je također povezana i sa sintaksom i stilistikom.

Prema našoj prosudbi frazeologiji više ne odgovara ograničavanje unutar leksikologije jer bi joj ti okviri bili preuski i pomalo tijesni. Unatoč tomu ostaje na poseban način povezana s leksikologijom i u surječju supostavnoga proučavanja hrvatske i talijanske frazeologije i općenito frazeologije romanskih jezika osobito su joj vrijedna suvremena leksikološka istraživanja te proučavanje hrvatsko-talijanskih međujezičnih dodira, utjecaja, posuđivanja, kalkiranja, uloge jezikā posrednika i zamjetne leksičke konvergencije europskih jezika (usp. Ljubičić 2009; 2011; Turk 2013).

Današnje vrijeme nesklono je definicijama i velikim slučajevima. No to nije slučaj samo s frazeologijom. I interdisciplinarnost, unatoč tomu što za frazeologiju ima osobitu važnost, nije također novina, a taj interdisciplinarni pristup spominje već i Burger 1982. godine. Međutim, tipično je da na početku bilo kakvoga bavljenja znanošću stoji „omeđivanje i isključivanje ove pojave s pomoću radne definicije“ (Schwarz-Friesel 2007, 43).

Frazeološkim istraživanjima, navlastito u našemu jezikoslovlju, valja posvetiti veću pažnju, poglavito u supostavnim istraživanjima s romanskim jezicima, prateći razvoj supostavnih raščlambi među romanskim jezicima, čemu se dosad nije posvećivala veća pažnja te svakako s njemačkim, mađarskim i turskim jezikom.

Na osobit način valja se pozabaviti i dijakronijskim istraživanjima u hrvatskome jeziku kao i arealnim pristupom u istraživanju nacionalne frazeologije, ne zaboravljajući pri tome sve spoznaje supostavnih raščlambi na području leksikologije, ali i sintakse.

Premda je učinjeno mnogo na području istraživanja frazeologije slavenskih jezika, frazeologija bi svakako trebala biti samostalna i jaka jezikoslovna disciplina i u našemu jezikoslovlju.

Glede odnosa prema paremiologiji ${ }^{10}$ (grč. paroimia: 'poslovica'), odnosno jezikoslovnoj poddisciplini koja se bavi proučavanjem i tumačenjem poslovica, može se reći

\footnotetext{
$10 \mathrm{Za}$ razliku od paremiologije, paremiografija se bavi prikupljanjem, razvrstavanjem, popisivanjem $\mathrm{i}$ leksikografskom obradbom poslovica. Paremiografska tradicija iznimno je stara u ljudskoj povijesti općenito. U romanskim jezicima poznate su zbirke poslovica još iz srednjega vijeka i paremiografska tradicija utjecala je i na razvoj frazeografije romanskih jezika (usp. primjerice za francuski jezik Lengert 2007; za talijanski Fanfani 2007; za španjolski Pamies 2007).
} 
da se uglavnom drži da su posrijedi dvije srodne discipline. Često se paremiologiju drži odvojenom od frazeologije.

Dugo vremena poslovice nisu bile predmetom lingvističkih istraživanja. Njima su se uglavnom bavili etnolozi. Nerijetko su ih prikupljali i tumačili lokalni entuzijasti koji tome problemu nisu pristupali sa znanstvenom strogošću. Međutim, zahvaljujući velikom prikupljenome materijalu ,mnogi rezultati prvotno etnološkoga istraživanja mogu biti plodni i za jezikoslovlje“ (Burger 2015, 129).

Etnolozi su se uglavnom zanimali za podrijetlo poslovica, za njihove „migracije“ i uklapanje u kulturno-povijesne i socijalno-povijesne odnose (usp. Burger 2015, 107).

Dakle, paremiologija se razvila „u okviru znanosti o folkloru“ (Matešić 1978, 221). Njezin pak zadatak nije bio samo prikupljanje poslovica, nego i njihovo objašnjenje „, dijakronoga i sinkronoga gledišta“ (isto).

Prema Fleischeru (1994), „poslovice nisu frazemi“. Za razliku od rutinskih formula i frazema koji se reproduciraju kao jedinice jezičnoga sustava, poslovice se „,navode kao tekstovi, a to znači: govornik izričito pokazuje da određena rečenica [...] ne potječe od 'onoga koji je navodi', nego je on samo spominje, pozivajući se na višu instanciju“ (Fleischer 1997, 255).

Dakle, posrijedi su mikrotekstovi koje neki frazeolozi isključuju iz frazeoloških istraživanja.

Antica Menac već 1972. godine pojam frazema rabi u širemu značenju i ,pod frazemom uvrštava složene i stabilne strukture kao što su poslovice, neki složeni stručni nazivi, kolokacije i slično“ (Turk 2013, 85).

Još u svome djelu Handbuch der Phraseologie Burger (1982, 39) drži da su poslovice također frazemi i predlaže da se „u budućnosti ne pravi podjela na frazeologiju i paremiologiju i da se cijelo područje označi nazivom frazeologija“.

Otad je podjela na frazeologiju i paremiologiju ${ }^{11}$ sporna i poslovice se uključuju u klasifikaciju frazema ili ih se ne spominje.

\footnotetext{
${ }^{11}$ U Italiji se Temistocle Franceschi od sredine pedesetih godina prošloga stoljeća bavio prikupljanjem i obradbom paremiološkoga materijala po talijanskim regijama i utemeljio je disciplinu koju je nazvao geoparemiologijom ili teritorijalnom paremiologijom (tal. geoparemiologia o paremiologia territoriale). Dakle, posrijedi je prikupljanje i istraživanje poslovica na temelju teritorijalnoga načela. Inspiracija za utemeljenje ove discipline bili su lingvistički atlasi (usp. Franceschi 2017, 17).
} 
I u novijim radovima Burger drži da je danas neprijeporno da su „poslovice od velikoga interesa za jezikoslovlje i da se smatraju važnim područjem frazeoloških fenomena“ (2015, 129).

On poslovice ubraja u tzv. „referencijalne frazeme“ (Burger 2015, 35). Poslovice su „u sebi zatvorene rečenice koje ne trebaju nikakav leksički element da bi ih se uključilo u kontekst" (Burger 2015, 107).

Problem je podjele na frazeologiju i paremiologiju i u samoj poteškoći definiranja poslovice oko čega ne postoji opće suglasje. Stoga frazeolozi pokušavaju „fenomene slične poslovici (Keil 1997, 13) kao sentencija, apoftegma, dosjetka (bon mot), maksima, epigram, slogan ili krilatica odvojiti od poslovice“ (Donalies 2009, 92).

Prema Umurovoj $(2005,25)$ sentencija bi bila „kratka rečenica s uglavnom filozofskom izjavom, a poslovica potječe često iz svagdašnje životne situacije, dok je aforizam neovisna, kratka i duhovita sažeta misao čija je važna odlika originalnost““.

Stoga se Donalies $(2009,93)$ pita koliko su „kriteriji kao 'kratak, 'filozofski', 'duhovit' ili 'originalan' magloviti i time nisu baš od pomoći za znanstveni diskurs“" i s pravom se pita trebaju li frazeolozima uopće tolike ,podgrupe i podgrupice kako bi mogli shvatiti i opisati fenomen poslovicu?“ (isto).

U Hrvatskoj enciklopediji pod natuknicom aforizam može se pročitati da je aforizam: „izreka koja se jezgrovitim, poentiranim oblikom izdvaja iz proznog teksta u kojem se pojavljuje. Nefikcionalnost ju razlikuje od vica i anegdote, prozni značaj od gnome i epigrama, izlučenost iz cjeline od filozofske teze, a individualno autorstvo od poslovica i krilatica. U aforizmu se misao, uvid, sud ili stav obično formuliraju u obliku antiteze, paradoksa, hiperbole, igre riječima, aluzije ili kakva obrata. Pojavljuje se kao medicinski poučak (Hipokrat, Galen), zatim u učenjačkim zbirkama (Plutarh, Erazmo Roterdamski, F. Bacon), u religijskoj literaturi (Biblija, Talmud) i u filozofskoj tradiciji (Seneka, Marko Aurelije, A. Schopenhauer, F. Nietzsche)“. ${ }^{12}$

\footnotetext{
$12<$ http://www.enciklopedija.hr/natuknica.aspx?id=691> (16.7.2019.).
} 
Sve to upućuje da je za paremiologiju zasad teško stvoriti jasne kriterije za definiranje i klasifikaciju najprije poslovice, potom svih ostalih fenomena i da će se frazeolozi i paremiolozi još neko vrijeme morati pozabaviti terminologijom i mogućom klasifikacijom.

Međutim, paremiološka istraživanja mogu biti od velikoga interesa za lingvistiku i opće koristi za proučavanje jednoga jezika jer kako za talijanski jezik naglašava Franceschi „l'italiano scritto e, più, parlato presenta un'estrema libertà sintattica, superata soltanto dalle lingue antiche, fondate sulle desinenze e quindi slegate da ordinamenti fissi“" $(2017,27)$. K tome napominje da sve te uobičajene sheme nadilazi jezik poslovica „che mira a evidenziare nell'ordine sintattico, e più ancora logotattico, l'elemento a cui intende dare maggior rilievo, producendo così una varietà di costrutti che danno vita a prodotti di grande efficacia, degni d'esser riguardati come piccoli capolavori della letteratura orale - pur se quando venissero introdotti in un componimento scolastico verrebbero inesorabilmente cassati“" (isto).

Paremiologija i frazeologija uopće zaslužuju ozbiljniji lingvistički pristup i nipošto se ne mogu držati rubnim fenomenima jezika čije se istraživanje prepušta samo nelingvistima i zaljubljenicima u folklor, usmenu književnost i povijest. Štoviše, upravo je u ovome slučaju nužna suradnja s različitim znanstvenicima i naglašena interdisciplinarnost.

S obzirom na svoju specifičnost i složenost, paremiologija zacijelo treba posebne metode proučavanja, a pojmovlje i metodologija još će se dugo bistriti, što opet ne znači da je se treba odvajati od frazeologije i držati posvema odvojenom disciplinom.

\subsection{Frazeologija u užemu i širemu smislu}

Dugo se u frazeološkim istraživanjima frazeologiju dijelilo na centar i periferiju, odnosno na frazeologiju u užemu i širemu smislu. Iako te podjele i danas dobrim dijelom vrijede, pristup je diferenciraniji.

U njemačkome jezikoslovlju i frazeološkim istraživanja od samih je početaka postojala svojevrsna podjela na one koji se bave frazeologijom u užemu i one koji se bave frazeologijom u širemu smislu. Te dvije struje koje su se od samoga početka razlikovale i bile u nekome obliku konkurencije i pozitivnoga antagonizma predstavljaju s jedne strane Wolfgang Fleischer koji u biti svojim djelom obuhvaća rezultate frazeoloških istraživanja u nekadašnjemu DDR-u. On se zalaže za frazeologiju u ,užemu smislu“. Svoje stavove zastupa i dorađuje i u drugome izdanju 
svoje knjige koje je objavljeno 1997. godine. Za razliku od njega, Burger / Buhofer / Sialm zalažu se za frazeologiju u ,širemu smislu“ (usp. Burger 2006). Prema tome u frazeologiju u užemu smislu ubrajale bi se samo „one sveze za koje strogo odgovaraju glavna frazeološka načela (polileksikalnost, stabilnost, idiomatičnost), pri čemu osobito (semantička) idiomatičnost igra presudnu ulogu“ (Burger 2005).

Frazeologija u užemu smislu odnosila bi se dakle na „ustaljene desemantizirane sveze riječi koje se reproduciraju u gotovu obliku ustaljenu dugom uporabom. Kako su sastavnice takvih skupova riječi desemantizirane u manjem ili većem stupnju, značenje pojedinačne frazeološke jedinice ne odgovara zbroju značenja svih sastavnica. Sastav i redoslijed tih frazema uglavnom je stabilan i nepromjenjiv““(Vidović Bolt 2011, 16).

Frazeologija u širemu smislu obuhvaća ustaljene sveze riječi čije sastavnice nisu desemantizirane ili je provedena samo djelomična desemantizacija. Frazemi koji spadaju u frazeologiju u širem smislu ne odlikuju se ekspresivnošću i konotativnim značenjem, kao ni idiomatičnošću. Njima je svojstvena ustaljenost izraza, čvrsta struktura, cjelovitost (usp. FinkArsovski 2002, 7).

Dakle, frazeologija u širemu smislu obuhvaća sve frazeme, dok frazeologija u užemu smislu obuhvaća idiome.

O frazeologiji u širemu smislu govorimo kada frazemi pokazuju sljedeća dva obilježja: polileksikalnost i čvrstoću. Polileksikalnost znači da se frazem sastoji od više od jedne riječi. ${ }^{13}$ Stabilnost frazema znači da ga poznajemo „baš u ovoj (ili vrlo sličnoj) kombinaciji riječi i slično kao jedna riječ - rabi se u govornoj zajednici““(Burger 2015, 14).

Prema Burgeru govorimo o frazeologiji u užemu smislu ako tim dvjema odlikama pridodamo još i idiomatičnost. Pod time mislimo da ,sastavnice ne stvaraju jedinice koje se mogu posvema objasniti sintaktičkim i semantičkim regularnostima povezivanja. Podvrsta frazema koji ispunjaju ovaj kriterij tvori polje idioma“ (Burger 2015, 15).

Burger drži da se u skladu s novim istraživanjima, osobito u istraživanju kolokacija pokazalo da se uže i šire područje frazeologije ne daju tako jasno odvojiti jedno od drugoga kako se to ranije mislilo i kako to zastupaju mnogi frazeolozi te da ,striktno razgraničavanje nije ni ostvarivo, a ni poželjno“ $(2015,15)$.

\footnotetext{
${ }^{13}$ Što to pak znači, među vodećim frazeolozima postoje oprečna mišljenja.
} 
A za to striktno odvajanje zalaže se Fleischer koji kaže da je ,težnja za što je moguće objektivnijim kriterijima na temelju metodički zatvorene koncepcije dovela uglavnom do užega poimanja“ (1997, 23). U tome načinu promatranje postrance ostaju „s jedne strane frazemi s rečeničnom strukturom, a s druge strane neidiomatske čvrste sveze riječi“ (isto). Premda naglašava da je jasno da frazemi s obzirom na svoju idiomatičnost pokazuju razlike, Fleischer (1997, 23) drži da treba dalje produbljivati „u kojoj se mjeri mogu prepoznati stupnjevi idiomatičnosti“" te se pita ima li smisla apsolutizirati obilježje leksikaliziranosti frazema, njegove pohrane kao jedinice u leksikonu, jer to dovodi do pitanja „takozvanih 'autorskih frazema' koji su kao metaforični izričaji povezani s jednim tekstom ili autorom, a da ne ulaze u opći sastav leksikona“ (isto). Sve to otvara pomnjivije proučavanje odnosa metaforizacije i frazeologizacije.

Prema Fleischeru problematično je i pitanje uključivanja „onimskih i terminoloških jezičnih skupina“" u frazeme $(1997,23)$.

Burger pak tvrdi da se zahvaljujući korpusnolingvističkim istraživanjima stara predodžba o centru i periferiji u frazeologiji mora staviti u pitanje. „Jezična povijest daje daljnje indicije barem za to da se to razgraničenje mora bitno olabaviti. Navest ćemo sada indicije koje smo pronašli:

- Čvrstoća (stabilnost) sveza riječi jest parametar koji se samo u vrlo ograničenome obliku da primijeniti na historijske jezične prilike.

- Obrasci i modeli igraju puno veću ulogu nego što je se to dosad pretpostavljalo.

- Opisano međustanje metaforičnih i metonimijskih područja između kolokacija i idioma otežava razgraničavanje (omeđivanje) unutarnjega područja idiomatike ili ga pak čini nemogućim“" $(2012,17)$.

Premda je u početku frazeoloških istraživanja podjela na centar i periferiju bila od koristi za frazeologiju jer se na taj način moglo usmjeriti istraživanja, odnosno omeđiti područje zanimanja i usredotočiti istraživanja na frazeologiju u užemu smislu, vremenom se pristup frazeologiji mijenjao, a interdisciplinarna istraživanja bila sve brojnija. Frazeme se više počelo promatrati u odnosu prema kulturnome okruženju u kojemu su nastali, naglo je porastao broj kontrastivnih istraživanja sa srodnim jezicima, ali sve više i jezicima koji su genetski i tipološki potpuno drukčiji. Promatranje frazema s dijakronijskoga stajališta uz korpusnolingvistička 
istraživanja pomiče zanimanje i na frazeologiju u širemu smislu tako da danas mnogi frazeolozi ne polažu veliku vrijednost na točno razlikovanje frazeologije u užem i širem smislu.

U okviru istraživanja historijske frazeologije Burger $(2012$, 11) upozorava da nas je „fokusiranje istraživanja na idiome, ${ }^{14}$ a tu osobito na figurativnost idioma odmaklo od spoznaje o zbiljskoj složenosti frazeoloških razvojnih tijekova“.

Holističko-integrativni pristup koji se širi u frazeologiji i čija se načela osobito u posljednjim godinama dorađuju na frazeološkim konferencijama i u novijim radovima dovest će do daljnjih pomaka i proširenja frazeoloških spoznaja, a vjerojatno i do redefiniranja mnogih pojmova.

\subsection{Zadaće kontrastivne (poredbene) frazeologije}

Usporedba jezičnih sustava nije novijega datuma i poznata nam je iz 18. i 19. stoljeća u okviru poredbenopovijesnoga jezikoslovlja koje je na temelju usporedbe jezikā otkrilo genetsku srodnost među jezicima, jezike svrstavalo u porodice i nastojalo rekonstruirati prajezik iz kojega su ti jezici potekli. Uopće, velika je važnost usporedbe među jezicima za jezikoslovlje jer se jezik ,ne može znanstveno proučavati ukoliko se u vidu ima samo jedan jezik, ili ograničen skup jezika“ (Matasović 2001, 7).

Poredbena metoda pridonijela je također i istraživanju ne samo srodnosti među jezicima, njihovu svrstavanju u jezične porodice ili otkrivanju jezičnih saveza ili tipoloških obilježja, nego je također zahvaljujući svojim plodnim istraživanjima omogućila „da postavljamo pitanja, ne samo o materijalnom, već i o duhovnom svijetu govornika prajezika““ (Matasović 2001, 55).

Budući da je poredbeno jezikoslovlje iznimno pridonijelo razvoju lingvistike općenito, jasno je da je i poredbena frazeologija itekako važna za razvoj frazeologije kao jezikoslovne poddsicipline.

Kontrastivna (poredbena) frazeologija danas je vrlo živ dio frazeologije i cilj joj je proniknuti u razlike i sličnosti (divergencije i konvergencije) između frazeoloških (sub)sustava,

\footnotetext{
${ }^{14}$ Prema Burgeru idiomi su podrazred frazema koji uz načela polileksikalnosti i stabilnosti strukture ispunjaju i načelo idiomatičnosti (usp. Burger 2015, 15).
} 
tj. na taj način mogu se u različitim jezicima učinkovito „utvrditi razlike, ali i strukturne i semantičke podudarnosti““ (Turk; Opašić 2008, 19).

Kontrastivna frazeologija postoji od početaka kontrastivne lingvistike i frazeoloških istraživanja u šezdesetim godinama 20. stoljeća (usp. Hallsteinsdóttir 2014, § 3.).

Sovjetska frazeologija bila je dobrim temeljem za kontrastivna istraživanja. Ruski jezikoslovac Aleksandr D. Rajchštejn (1980) u svojim je istraživanjima stvorio pretpostavke za razvoj kontrastivne frazeologije.

Od samoga početka kontrastivna je frazeologija pridonijela otkrivanju „međujezičnih i općenito lingvističkih spoznaja“ (Földes 2006, 11), ali je također bila vrelom teorijskih spoznaja.

Fleischer se zalagao da se u kontekstu ,konfrontativne lingvistike razvije i konfrontativna frazeologija“, a cilj konfrontativne frazeologije bio bi „supostavno istraživanje frazeoloških sustava dvaju ili više jezika i prikaz i pojašnjenje zajedničkih značajki te razlika“" $(1997,25)$.

Mnogi istraživači, osobito u bivšemu Sovjetskom Savezu razlikovali su „usporedbu“ i „kontrast“. Prema tome govorimo o usporedbi sa srodnim jezicima, a o kontrastu s nesrodnima. Földes $(1997,167)$ tu podjelu ne drži „smislenom i razumljivom“ i budući da u suvremenoj literaturi ionako nije uobičajena, rabi se pojam „kontrastivna frazeologija“ i ne pravi se razlika između „kontrastivne“ i „konfrontativne“ frazeologije, što je bilo uobičajeno među frazeolozima u bivšemu DDR-u.

Kontrastivna istraživanja mogu biti unutarjezična ili međujezična.

Unutarjezična frazeološka istraživanja mogu biti usporedba frazeologije primjerice standardnoga hrvatskog jezika i čakavske frazeologije ili standardnoga talijanskog jezika i sicilijanske frazeologije.

Međujezična kontrastivna istraživanja mogu biti usporedbe hrvatske i talijanske frazeologije općenito prema nekome kriteriju ili primjerice usporedba binoma u talijanskome i hrvatskome ili pak frazema biblijskoga podrijetla, dakle usporedba određenih mikrosistema u dvama jezicima ili u više njih. 
U znanstvenoj literaturi često se kontrastivna frazeologija „ograničavala samo na međujezičnu usporedbu“ (Zeman 2006, 303). Dugo se vremena ionako nije posvećivala neka posebna pažnja proučavanju frazema u arealnim okvirima. To je bio posve zapušten vid pristupa proučavanja frazema (usp. Piirainen 2008).

Tradicionalno se u kontrastivnoj frazeologiji uspoređuje ili značenje ili oblik, a u novije vrijeme tomu se može pridodati i usporedba funkcije u jezičnoj uporabi (usp. Hallsteinsdóttir; Farø 2010, 141).

U novije vrijeme porastao je broj kontrastivnih radova, no opet to ne znači da je to područje dovoljno istraženo i da ne može biti još mnogo otkrića od velike važnosti za frazeologiju općenito, ali i za povijest pojedinih jezika.

S time u svezi Jerolimov ističe: „Pitanje kontrastiranja i prenošenja frazeoloških jedinica iz jednoga jezika u drugi jedno je od najsloženijih pitanja kontrastivne lingvistike. Stoga posebno u okvirima dvojezične leksikografije, prevoditeljstva te nastave stranih jezika toj problematici treba posvetiti posebnu pozornost. Ne začuđuje, stoga, činjenica što je još uvijek relativno malo radova s područja kontrastivne frazeologije“ $(2001,87)$.

Prema Földesu (1997) zadaće kontrastivne frazeologije bile bi:

- ,pronalaženje podudarnosti, sličnosti i razlika u jezicima / jezičnim varijetetima koji se uspoređuju

- unutarjezični opis, tj. polje istraživanja valja kvalitativno opisati i kvantitativno inventarizirati

- usporedivost

- određenje invarijante s obzirom na koju se prosuđuju sličnosti i razlike

- primjena jedinstvenoga teorijskog koncepta za interpretaciju pojava u jezicima / jezičnim varijetetima koji se uspoređuju.“

Kontrastivna metoda služi se uglavnom indukcijom jer su frazemi „znakovne skupine nastale 'sekundarno' koje su izgrađene od jedinica primarnih sustava (leksika, sintakse, morfologije), stoga se mogu razumjeti složenom usporedbom primarnih jedinica sustava koje ih čine“" (Földes 1997, 169). 
Glede leksičkoga vida najprije valja proučiti „koje su sastavnice (tematske skupine sastavnica) u frazeologijama dvaju ili više jezika koji se uspoređuju često, odnosno rijetko zastupljene u frazemima“" (Zeman 2006, 305). Glede strukturno-sintaktičkoga vida opisuje se struktura i sintaktičke funkcije frazema, primjerice udio verbalnih odnosno nominalnih frazema. Strukturno-semantički vid pak opisuje koja tematska područja frazemi pokrivaju. Frazemima se uglavnom označuju „osjećaji, afekti, karakterne osobine, mišljenje, društvo, etika, dok su frazemi koji tematiziraju književnost, znanost i tehniku iznimno rijetki““(isto).

Temeljni pojam kontrastivne frazeologije jest ekvivalencija. Cilj kontrastivnih istraživanja i jest određivanje ekvivalencije, tj. jednakovrijednosti frazeoloških sveza između dvaju jezika ili među više njih. Ekvivalencija se može odnositi na oblik, značenje ili funkciju jezičnih znakova. Tradicionalno se razlikuje „kvalitativna (vrsta jednakovrijednosti, tj. značenje i struktura ekvivalenata) i kvantitativna (broj jednakovrijednih frazema) ekvivalentnost“" (Hallsteinsdóttir 2014, § 3.).

Kontrastivna istraživanja osobito su uznapredovala $\mathrm{u}$ posljednjim desetljećima i uklopila su se u šaroliki spektar interdisciplinarnih istraživanja, a na poseban način pridonijela su uočavanju posebne povezanosti frazema i kulturnoga kruga u kojemu su nastali te promatranju frazema u širim, arealnim okvirima.

Premda su uglavnom istraživanja sinkronijskoga tipa, moguće je istraživati i dijakronijski, primjerice slijed sastavnica binoma u talijanskome i hrvatskome i njihovu ireverzibilnost u talijanskome i hrvatskome u posljednjih nekoliko stoljeća.

Međutim, u kontrastivnu frazeologiju spadaju također „usporedbe koje se usredotočuju na usporedbu drugih fenomena kao što su kultura, simbolika i figurativnost u koje se frazemi uključuju kao dio jezika““ (Hallsteinsdóttir; Farø 2010, 130).

Rezultati istraživanja kontrastivne frazeologije bitno su pridonijeli produbljenju znanja o učenju i uporabi frazema u stranome jeziku tako da je ovo poglavlje od velikoga zanimanja i s didaktičkoga stajališta.

I sami iz vlastitoga iskustva vidimo da je kontrastiranje vrlo učinkovita metoda za produbljenje znanja i o materinskome jeziku. Mnoge konstrukcije ne bismo možda niti zapazili da ih nismo usporedili s drugim jezikom ili pak unutarjezično s drugim varijetetom, ,jer kontrastiranjem dvaju ili više jezika bolje se mogu prepoznati unutarjezične posebnosti koje je izvorni govornik interiorizirao kao nešto samorazumljivo“(Chrissou 2000, 79). Katkad izvorni 
govornici uopće ne primjećuju da je posrijedi frazeološka sveza riječi jer su frazemi nerijetko semiotički neupadljivi (usp. Hallsteinsdóttir; Farø 2006, 3).

U jednome se jeziku primjerice definiraju idiomatskima „forme, strutture ed espressioni che siano proprie e specifiche di una lingua“" (Casadei 1996, 28). Međutim, prepoznajemo ih često tek usporedbom s drugim jezicima gdje takve strukture ne postoje ili postoje u drugim oblicima, s određenim razlikama, posebnostima itd. Stoga Greimas (prema Casadei 1996, 28) ustvrđuje: „le jugement idiomatique ne peut être que le résultat d'une comparaison“.

Rezultati istraživanja kontrastivne frazeologije osobito su zanimljivi i korisni i za znanost o prevođenju (traduktologiju) jer je zamršen proces prevođenja upravo toga dijela svakoga jezika na drugi jezik i da bi prijevodni ekvivalenti bili odgovarajući, zahtijeva se dobro poznavanje kultura i duha nekoga jezika, osobito kad su posrijedi nesrodni jezici ili prijevodi s nekih egzotičnih jezika. To katkad može biti krajnje složeno čak i u vrlo bliskim jezicima.

Iako postoje frazemi koji su specifični za neki jezik, postoje i „univerzalna iskustva čija se 'slika' prenosi na ustaljene izraze“ (Maček 1992 - 1993, 269). Stoga su određeni frazemi „,zajednički određenim skupinama jezika, koje se ne moraju nužno poklapati s jezičnim srodstvom“ (isto).

Pri supostavnim raščlambama talijanskoga s hrvatskim važno je uzeti u obzir sve te činjenice. Maček govori o različitom dometu rasprostranjenosti frazema (koje ona naziva idiomatskim frazama). Predlaže rasprostranjenost koja bi se moga „klasificirati na univerzalnu rasprostranjenost, zatim na onu koja obuhvaća s jedne strane zapadnu a druge istočnu civilizaciju i sl., zatim sveeuropski kulturni krug, a onda dosta karakteristično razgraničenje unutar toga kruga na srednjoeuropsko-njemački krug, koji većinom obuhvaća slavenske i skandinavske zemlje, te zapadnoeuropski i francuski krug, koji se obično prostire i na Englesku, ali i na Njemačku i na zemlje njezinog kruga“ (Maček 1992 - 1993, 272).

Osim toga, važno je uzeti u obzir i dijatopiju jer su dijalekti „ostavili jasne tragove u frazeologiji i standardnoga jezika kao i u standardu bliskim, usmenim kolokvijalnim jezicima“ (Piirainen 2006, 196).

Zanimljivo je da i u talijanskim dijalektima imamo sličnih germanizama kao u hrvatskome standardnom jeziku. Ljubičić $(2011,107)$ konstatira da u „tršćanskim, furlanskim i mletačkim rječnicima nalazimo brojne germanizme koji postoje $s$ istim značenjem i u hrvatskome, na razini standardnoga jezika, kao kolokvijalizmi ili kao dijalektalizmi“. 
Također treba imati na umu veću zastupljenost romanizama i germanizama u hrvatskim dijalektima u odnosu na standardni jezik (usp. Ljubičić 2011, 190).

Piirainen (2006) upućuje i na mogući utjecaj jezičnih saveza na frazeologiju pojedinih jezika. U europskim jezicima prepoznaju se široke zajedničke značajke morfološke, sintaktičke i semantičke naravi. Sva ta obilježja nije moguće svesti na genetsku srodnost. Pojmovi kao interfrazem (interfrazeologizam) ili internacionalizam još uvijek se $u$ frazeološkim istraživanjima drže presmionima. Stoga su frazeološki europeizmi još vrlo sporan pojam.

Međutim, i u našim dosadašnjim supostavnim frazeološkim raščlambama prepoznalo se vrlo jasno da hrvatski jezik nedvojbeno pripada „srednjoeuropskome i mediteranskome kulturnome krugu. Jezične su podudarnosti dijelom rezultat kalkiranja, u čemu su veliku izravnu i posredničku ulogu imali njemački i talijanski jezik“ (Turk; Opašić 2008, 29).

Kontrastivna istraživanja mogu bitno pridonijeti i kakvoći frazeografskih radova premda je u tome pogledu na kontrastivnoj usporedbi hrvatskoga s talijanskim dosta urađeno.

U posljednjim se godinama $u$ okviru kontrastivne frazeologije sve više govori i o interkulturalnoj frazeologiji. Interkulturalna frazeologija trebala bi objasniti ono što međujezična kontrastivna frazeologija ne uspijeva.

Hallsteinsdóttir (2014) uspoređuje primjerice uporabu pozdrava u njemačkome i danskome jeziku i upozorava na različitosti. Uz dosadašnji način pristupa i raščlambe $u$ okvirima kontrastivne frazeologije ona uključuje sociokulturne kriterije kao primjerice situacijsku uporabnost (odnos spomenutih pozdrava prema drugim pozdravima) u kombinaciji s kulturno specifičnim komunikacijskim pravilima i kognitivnim strukturama mišljenja i djelovanja koji imaju utjecaja na uporabu pozdrava jezičnim zajednicama koje su predmetom raščlambe.

Takvi sociokulturni i kognitivni vidovi ekvivalentnosti jesu polazište za interkulturalnu frazeologiju.

Temeljem nastanka interkulturalne frazeologije jest poglavito razvoj holističkointegrativnoga pristupa koji razvijaju Hallsteinsdóttir i Farø (Hallsteinsdóttir 2006; Hallsteinsdóttir; Farø 2010). U to bi se uključila i frazeologija i pojedine riječi. Hallsteinsdóttir i Farø (2006) drže da su frazemi potpuno normalne leksičke jedinice čija se opsežnija istraživanja mogu vršiti samo u odnosu prema drugim jezičnim znakovima. Koja uloga pri tome 
pripada odnosu i prožimanju jezika i kulture, još se mora objasniti. I to bi prema Hallsteinsdóttir (2014) pripadalo zadaćama interkulturalne frazeologije. Teži se nadilaženju dosadašnje usporedbe izoliranih frazema na razini jezičnoga sustava koja je bila uobičajena u kontrastivnoj frazeologiji kao i široko shvaćeni kontrastivni opis leksika (usp. Hallsteinsdóttir 2014). K tome, valja temeljito istražiti i opisati odnos jezika i kulture kako bi se izgradio solidan temelj za razvoj interkulturalne frazeologije.

\section{5. (Neprepoznata) važnost povijesne frazeologije}

Poznato je da je zanimanje za značenje frazema te navlastito idioma veliko kod mnogih govornika hrvatskoga jezika, a na to upućuju i mnogi radovi posvećeni toj temi kao i rasprave po internetskim forumima. Ista se stvar može reći za govornike talijanskoga i ostalih romanskih jezika.

Uglavnom se dobro poznaje podrijetlo mnogih idioma, poslovica, krilatica itd. i na tome se dosta radilo. Osobito talijanski rječnici frazema i poslovica uglavnom imaju i objašnjenja odakle frazem, krilatica, poslovica potječe, kada je nastala itd. (usp. npr. Lurati 1998; 2001 ili Pittano 2014). Od 19. stoljeća kada uz primjenu historijske metode počinjemo govoriti o znanstvenome bavljenju etimologijom u modernome smislu riječi, romanski su jezici bili idealno tlo jer im je poznato ishodište, latinski jezik. I u drugim jezicima etimološka istraživanja, osobito nakon pojave lingvističke geografije u znanstvenome smislu, doživljavaju veliki napredak.

No $\mathrm{u}$ frazeologiji dugo nije bilo zanimanja za historijske odnose osim ovoga etimološkog traženja ,iskona“ i ,pravoga značenja“. Historijska frazeologija dugo je bila „u sjeni na rubovima mainstreama povijesnojezičnih istraživanja“" (Burger 2015, 2).

Fleischer opominje i u svome dopunjenom drugom izdanju da su pak historijska frazeološka istraživanja ,posvema na početku“. Iako se, kako je gore spomenuto, radilo na etimologiji frazema, „dijakronija frazeološkoga blaga, razvojne tendencije frazeologije, karakteristični čimbenici frazeologizacije“ $(1997,26)$ jedva su se uzimali u obzir.

Frazeolozi su spoznali da ,čisto sinkronijskim rasvjetljavanjem (frazeološke) jezične povijesti - ili u krajnjemu slučaju čak samo njezine polazne i krajnje točke - previše vidova ostaje u sjeni“" (Burger 2012, 222). 
I zbilja, usporedi li se broj radova posvećenih današnjemu stanju u frazeologiji jezika, osobito onih u kojima postoje brojna istraživanja o toj temi, $\mathrm{s}$ brojem radova s dijakronijskoga stajališta, odmah se dade prepoznati da tu vlada veliki nesrazmjer.

Budući da u talijanskome nema mnogo istraživanja s područja frazeologije, teško je davati omjere, no i ono malo radova uglavnom je posvećeno suvremenomu talijanskom jeziku i njegovoj frazeologiji. Slična je situacija i u drugim romanskim jezicima te u usporedbi frazeologije različitih romanskih jezika s dijakronijskoga stajališta. U hrvatskome je jeziku znatno veći broj radova posvećen mnogim vidovima frazeologije. Više istraživanja posvećeno je i istraživanju frazeologije pisaca, bilo starije hrvatske književnosti: a) Marulića, Hektorovića i Gundulića (usp. Moguš; Menac 1989; Moguš 1990; Menac 1991), b) pisaca 17. stoljeća (usp. Kolenić 1997; Kolenić 1998), c) slavonskih pisaca 18. stoljeća (usp. Kolenić 1992 - 1993; Kolenić 1994) te pisaca 19. stoljeća (usp. Menac 1992), hrvatskih pisaca, filologa i leksikografa (usp. Stolac 1994; Matešić 1996) itd.

Svi su ti radovi i spoznaje svakako od velike koristi za suvremena istraživanja historijske frazeologije u skladu s novim spoznajama i pristupima.

Međutim, u nas kao i drugdje može se ustvrditi da se povijesna frazeologija kao „,znanstvena disciplina još nije etablirala u pravome smislu riječi“ (Bierich 2014).

Premda se dijakronijska semantika davno već razvila, i premda su etimološka i historijska istraživanja brojna i na području leksikologije, u frazeologiji im se ,posvećivalo znatno manje pažnje“ (Bierich 2014).

Tek u posljednjih nekoliko godina jača svijest o važnosti povijesne frazeologije i o proučavanju frazema s dijakronijskoga stajališta u znanstvenome smislu riječi.

Sve veće zanimanje za historijske odnose u frazeologiji i paremiologiji zamjetno je osobito od EUROPHRAS-ove konferencije u Helsinkiju 2008. godine, a na konferenciji na sveučilištu u Granadi 2010. godine jedna je sekcija posvećena vidovima historijske frazeologije i frazeografije (usp. Burger 2012).

Otad se puno ozbiljnije shvaća ,nužnost historijske dimenzije u lingvistički usmjerenome istraživanju frazeologije“ (Filatkina 2012, 21).

Razlog tomu zacijelo se prema Mokienku $(2002,231)$ treba tražiti u tome da je ,jezikoslovna obradba frazeologije počela u vremenu kada je povijesnoporedbeno jezikoslovlje 
u biti već svoje učinilo i moralo prepustiti prvenstvo deskriptivnomu, strukturnoanalitičkomu, socijalnomu i psihološkomu jezikoslovlju. Frazeologiju pak povijesnoporedbeni skalpel praktično nije dodirnuo. U dijakronijskome spektru nije postala područjem zanimanja za jezikoslovce, nego poglavito za kulturologe, etnografe, mitologe i folkloriste“"

Kako za mnoge jezike ne postoje rječnici za starije faze jezika, između ostalih i za slavenske (usp. Bierich 2014), a frazeološka istraživanja počinju tek nakon mukotrpnoga ekscerpiranja odgovarajućih primjera, jasno je da se moraju ispuniti mnoge pretpostavke kako bi se moglo krenuti u opsežnija istraživanja frazeologije pojedinih razdoblja jednoga jezika. ${ }^{15}$

Što bi bila uopće historijska frazeologija?

I sam je pojam „sintagmatski zbroj dvaju vrlo nepreciznih pojmova“ (Burger 2015, 196).

Prema Burgeru i Linkeu historijska bi frazeologija bila ,povijest frazeologije sa svojim načelima tijeka koju doduše poradi nedovoljne osnove pojedinačnih studija i djela za konzultiranje valja još napisati““ (Burger 2015, 196).

Pri tome Fleischer $(1997,26)$ napominje da se pod pojmom historijskoga istraživanja frazeologije „ne drži samo dijakronijsko istraživanje, nego i sinkronijsko istraživanje i prikaz frazeologije starijih epoha naše jezične povijesti““.

„Utoliko je današnji jezik dinamična veličina u kojoj se pred našim očima odvijaju povijesni procesi. ${ }^{16}$ To vrijedi za cijeli jezik, ali se u frazeologiji osobito jasno očituje“ (Burger $2015,2)$.

Prema Bierichu u najvažnije zadaće historijske frazeologije spada: "a) izradba određenih metoda i načela historijsko-etimološke raščlambe; b) opis frazeološkoga sustava u

\footnotetext{
${ }^{15} \mathrm{U}$ romanskome jezikoslovlju inače je jako malo istraživanja frazeologije, poglavito s historijskoga stajališta. A upravo bi istraživanja na području frazeologije romanskih jezika, gdje bi s jedne strane Romania conservata, a s druge strane Romania nova bile plodno tlo za takva istraživanja, ali i Romania submersa, osobito s dijakronijskoga stajališta mogla na osobit način rasvijetliti mehanizme koji djeluju u europskoj frazeologiji na isti onaj način kako su to učinila povijesnoporedbena istraživanja romanskih jezika te etimološka istraživanja značenja riječi u romanskim jezicima.

${ }^{16}$ I Tekavčić napominje da u sinkroniji ima određene dinamičnosti: „Danas znamo i to da čiste, potpune sinkronije nema niti je može biti, jer bi potpuna sinkronija bila isto što i statičnost, a toga ni u jednom živom jeziku nema. Dokle god je, naime, jezik živ, tj. dok postoje izvorni govornici koji ga govore, u jeziku neprekidno postoji dijalektična jedinstvo s t ar o g a (što nestaje) i n o v o g a (što nastaje)“ (1979, 27). I Babić napominje: „Ako uzmemo današnje govornike jednoga književnog jezika, onda među njima imamo bar četiri naraštaja, dakle oni koji su školovani u rasponu od šezdesetak godina i nije normalno očekivati da se svi služe potpuno istim jezikom. Jezične su promjene vidljive već za dvadesetak godina. Imao sam prilike čuti za jezičnu pojavu koju su stariji naraštaji još aktivno upotrebljavali da pripadnik najmlađega kaže: Nikad čuo“" $(1989,1)$.
} 
ranijim razdobljima jezika; c) procesi nastanka frazema; d) područja iz kojih potječe frazeologija; e) razvoj frazema (leksička, morfosintaktička i semantička mijena; izumiranje frazeoloških jedinica); f) pronalaženje elemenata iz drugih jezika u frazeologiji itd.” (Bierich 2014, 2).

Frazeologija ima vrlo složene „razvojne obrasce“ (Burger 2015, 11) i stoga se i u teorijskome i u jezičnopovijesnome pogledu „treba čuvati od linearnih i jednotračnih razvojnih modela frazeologije“ (isto).

Prema Bierichu moguće je „historijsko istraživanje frazeološkoga inventara jednoga jezika samo pod različnim vidovima. Najprije je nužno stvoriti istraživačke instrumentarije za dijakronijski opis kako bi se dospjelo do pouzdanih rezultata“ $(2014,20)$.

On predlaže i razrađuje metode povijesno-etimološke raščlambe u kojoj bi lingvistički vid bio u prvome planu. ${ }^{17}$ Međutim, etimologija i povijesni razvoj frazema mogu se istražiti samo „uključivanjem njihovih inačica iz starijih razdoblja književnosti, sinonimskih i antonimskih frazema, čvrstih sveza s istim sastavnicama i materijala iz narječja, iz folklora i iz srodnih i nesrodnih jezika“ (Bierich 2014, 20). ${ }^{18}$ Pri tome se ne smije zaboraviti ni varijante „koje omogućuju rekonstrukciju uobičajene slike na temelju strukturno-semantičkih obrazaca. Izvanjezične datosti također su od iznimnoga značaja za nastanak mnogih fraza jer frazemi mogu odražavati drevne pojave materijalne i duhovne kulture jednoga naroda“ (isto).

Dräger (2012, 203) upozorava na nesklad i neravnotežu (njem. Schieflage) te jednostranu usmjerenost u koju su zapala frazeološka istraživanja i frazeografija te kao izlaz iz takve nepovoljne situacije on predlaže da se ,1) čisto etimološko dokumentiranje a) nastanka i b) fiksiranja frazema koje se općenito prakticira pod nadređenim pojmom 'historijske frazeologije' mora nadopuniti više holističkim promatranjem razvoja i promjene frazema“.

Stoga predlaže naziv ,'dijakronijska frazeologija' kako bi se naglasila procesualnost i živost u razvoju historijskih frazema. Time bi statički-pojedinačni pristup [...] koji je prišivak

\footnotetext{
${ }^{17}$ Iz iskustva znamo da pri određivanju etimologije nekoga frazema izvanjezični čimbenici (narodne predaje, sociološki i povijesni čimbenici itd.) igraju veću ulogu nego pri određivanju etimologije neke riječi. Međutim, preveliko oduševljenje za etnografske činjenice i težnja za povezivanjem frazema s određenim povijesnim osobama ili događajima često se pokazuje kao vrlo slaba točka etimologije (usp. Bierich 2014, 2).

${ }_{18}$ Jasno, za svaki frazem nije potrebno prolaziti sva ova načela jer se etimologija može odrediti uz pomoć materijala iz dijalektologije ili činjenica iz starijih jezičnih razdoblja. Za neke pak frazeme nije lako otkriti etimologiju i jedino je moguće postaviti relativno uvjerljive hipoteze (usp. Bierich 2014, 20).
} 
'historijske frazeologije' na temelju etabliranoga ograničavanja na etimologiju i terminološki izgubio na važnosti“ (isto).

$\mathrm{K}$ tome, to lingvističko usmjerenje dijakronijske frazeologije „bilo bi metodička i strukturna dopuna frazeoloških istraživanja koja su dosad bila jako kulturno-povijesno usmjerena“" (Dräger 2012, 204).

Dräger $(2012,204)$, raspravljajući o predmetu proučavanja dijakronijske frazeografije, predlaže uvođenje pojma „frazeološke mijene“ i predlaže tri razine na kojima frazemi mogu biti pod utjecajem mijene:

„1. formalno-strukturnu razinu

2. semantičku razinu

3. jezičnopovijesnu i kulturnopovijesnu razinu (uključujući i etimologiju)“.

Prema njegovu mišljenju svako promatranje frazema „bilo da je posrijedi frazeografska, istraživačka ili bilo koja druga perspektiva - može se samo cjelovito promatrati na temelju interferencije pojedinih razina“" (Dräger 2012, 205). 


\section{O POVIJESTI DOSADAŠNJIH ISTRAŽIVANJA}

\subsection{O povijesti istraživanja u Hrvatskoj}

Frazeologijom u Hrvatskoj prvi su se počeli baviti hrvatski rusisti. Godine 1971. Antica Menac objavljuje rad $O$ strukturi frazeologizma i time počinju frazeološka istraživanja u Hrvatskoj. Oko nje se okupljaju suradnici koji su stvorili Zagrebačku frazeološku školu. Usporedbom talijanske i hrvatske frazeologije prvi se bavio Josip Jernej (1982a).

Prvi frazeološki rječnik objavljuje Josip Matešić 1982. godine: Frazeološki rječnik hrvatskog ili srpskog jezika, a potom i Hrvatsko-njemački frazeološki rječnik 1988. godine. Prije objave tih rječnika i nakon nje uslijedilo je izdavanje niza dvojezičnih ili trojezičnih rječnika u nizu Mali frazeološki rječnici, a među njima i Hrvatskosrpsko-talijanski rječnik (Menac-Vučetić 1988).

Antica Menac, Željka Fink-Arsovski i Radomir Venturin izdali su već drugi Hrvatski frazeološki rječnik (2014). U posljednjim desetljećima izdano je i nekoliko drugih rječnika, među njima valja spomenuti Hrvatsko-romansko-germanski rječnik poredbenih frazema (Željka Fink-Arsovski sa suradnicima 2015). Objavljeni su brojni radovi posvećeni frazeološkim istraživanjima. Uglavnom su to radovi posvećeni supostavnoj analizi hrvatskoga s jednim slavenskim jezikom ili više njih. ${ }^{19}$

Mira Menac-Mihalić istraživala je posebice hrvatsku dijalektnu frazeologiju (npr. Menac; Menac-Mihalić 1997 ili Menac-Mihalić 2005).

Knjige o frazeologiji objavili su: Željka Fink-Arsovski 2002. godine pod naslovom Poredbena frazeologija: pogled izvana i iznutra, a Antica Menac 2007. pod naslovom Hrvatska frazeologija te Ivana Vidović Bolt 2011. Životinjski svijet u hrvatskoj i poljskoj frazeologiji I. i Barbara Kovačević 2012. godine Hrvatski frazemi ,od glave do pete”.

Marija Turk objavila je 2013. godine knjigu Jezično kalkiranje u teoriji i praksi: prilog lingvistici jezičnih dodira u kojoj u više navrata obrađuje i pitanje frazeologije te posebice frazeološkoga kalka. Ivana Filipović Petrović bavila se odnosom leksikografije i frazeologije i 2018. godine objavila je monografiju Kada se sretnu leksikografija i frazeologija. O statusu

\footnotetext{
${ }^{19}$ Zanimljivo je da u priručniku na hrvatskome Uvod u lingvistiku (usp. Glovacki-Bernardi 2001) frazeologiji nije posvećeno nijedno poglavlje. U priručniku temeljni lingvistički pojmovi, inače prijevodu djela Roberta Lawrencea Traska (2005) s engleskoga pojavljuje se samo natuknica frazem. Natuknice frazeologija, paremiologija, binom, kolokacija i sl. uopće se ne spominju.
} 
frazema u rječniku. Irina Budimir proučavala je frazeme s arealnoga i povijesnoga stajališta te njihovu leksikografsku obradbu i objavila je 2020. godine knjigu Frazemi prve hercegovačke hrvatske periodike na prijelazu iz 19. u 20. stoljeće i njihova leksikografska obradba.

Supostavnom raščlambom talijanskih i hrvatskih frazema bavili su se Josip Jernej (1982b; 1992 / 1993; 1996) te Maslina Ljubičić (1994; 2014), Maslina Ljubičić i Vinko Kovačić (2008), Marija Turk (npr. 1994; 1996; Turk; Spicijarić Paškvan 2014), Ivana Jerolimov (2001), Nina Spicijarić Paškvan (npr. Opašić; Spicijarić Paškvan 2010; Opašić; Spicijarić Paškvan 2011), Snježana Bralić (2011), Magdalena Nigojević (2007), Maja Opašić (npr. 2010; Opašić; Spicijarić Paškvan 2011), Maja Bezić (2015) i dr.

Supostavnom raščlambom talijanskih i hrvatskih binoma i slijedom njihovih sastavnica bavio se Pavao Tekavčić (1988), a utjecajem ograničenja salijentnosti (semantičkopragmatičkih hijerarhija) te metričkih ograničenja na linearni slijed sastavnica binoma u dvama jezicima bavio se Damir Mišetić (2018). Utjecaj ograničenja prominentnosti slogova na slijed sastavnica binoma istraživali su Irina Budimir i Damir Mišetić (2020).

Supostavnom raščlambom biblijskih frazema u hrvatskome i nekome slavenskom jeziku bavili su se Slavomira Ribarova i Ivana Vidović Bolt (2009), Zrinka Jelaska (2014), Maja Opašić (2014) itd.

Usporedbom manjega broja frazema biblijskoga podrijetla u talijanskome i hrvatskome jeziku bavile su se Marija Turk i Maja Opašić (2008), a Maja Opašić napisala je doktorski rad o biblizmima u hrvatskome jeziku (2013).

\subsection{O povijesti istraživanja u Italiji}

Za razliku od slavenskih jezika i njemačkoga, frazeologija i frazeološka istraživanja talijanskoga jezika još su u povojima. ${ }^{20}$

\footnotetext{
${ }^{20}$ To se pak ne može reći za frazeografiju u Italiji i u drugim romanskim zemljama. Premda razvoj frazeoloških istraživanja kasni za razvojem frazeologije u germanistici i slavistici, još su se u prošlim stoljećima brojni književnici i leksikografi zanimali osobito za poslovice, izreke, ali i frazeme talijanskoga jezika te drugih romanskih jezika. Mnogi poznati leksikografi bavili su se prikupljanjem i detaljnim opisom ovoga materijala koji se držao nezaobilaznim za proučavanje kulture i jezika jednoga naroda i frazemi su nerijetko ulazili u opće, historijske i deskriptivne rječnike talijanskoga jezika (usp. Fanfani 2007). Od 17. stoljeća može se govoriti o frazeografiji francuskoga jezika kao neovisnoj, a prethodila joj je paremiografska tradicija koja seže u 12. stoljeće (usp. Lengert 2007).
} 
U dosta modernih priručnika u kojima se obrađuje stanje u modernome jezikoslovlju, i to vrlo detaljno, ne samo fonologija / fonetika, morfologija i sintaksa, nego također i opća lingvistika, semantika, pragmatika, semiologija / semiotika, sociolingvistika, psiholingvistika itd. u kazalu se ne mogu uopće pronaći natuknice fraseologia, modi di dire, espressione idiomatica, binomio, collocazione itd. (primjerice usp. Dardano 2005; Simone 2011; Lombardi Vallauri 2013) ili se ova tematika obrađuje tek u kratkim crtama (usp. Pallermo 2015).

Slična je situacija i u priručnicima koji obrađuju romansku filologiju i lingvistiku. Frazeologija i temeljni frazeološki pojmovi uglavnom se uopće ne spominju (usp. primjerice Renzi; Andreose 2015; Varvaro 2001).

U lingvističkome rječniku Breve dizionario di linguistica autorice Federice Casadei (2017) pojavljuju se natuknice fraseologia, collocazione, polirematica, binomio i lessicalizzazione. Frazeme se uključuje u natuknicu polirematskih izraza (polirematica) i navodi se čak i klasifikacija frazema, u što se uključuje i paremiologiju. ${ }^{21}$

Glede razvoja frazeoloških istraživanja u romanskim zemljama, valja spomenuti razvoj frazeologije u Sovjetskome Savezu, gdje su otpočela prva istraživanja frazeologije nekih romanskih jezika.

Budući da su sovjetski lingvisti bili prvi koji su stvorili frazeološku školu, utjecali su na druge komunističke zemlje u Europi gdje se počela razvijati frazeologija, ali i primjerice na Kubu.

Neki kubanski jezikoslovci kao Antonia María Tristá i Zoila Carneado jedno su vrijeme boravili u Sovjetskome Savezu i napisali radove na španjolskome baveći se poglavito kubanskim varijetetom.

U osamdesetim godinama Alberto Zuluaga, podrijetlom Kolumbijanac koji je od 1967. boravio u Njemačkoj, u Tübingenu objavljuje doktorski rad o španjolskoj frazeologiji i u svoj rad uključuje metodologiju jezikoslovaca kao što su J. Casares, E. Coseriu, A. V. Isacenko, Ch. Bally, generativističke radove o toj temi itd. (Ruiz Gurillo 1997, 20).

Frazeologijom talijanskoga jezika bavila se među prvima Federica Casadei, koja je 1996. godine objavila knjigu Metafore ed espressioni idiomatiche.

\footnotetext{
${ }^{21}$ Zanimljivo je da je ista autorica jedna od malobrojnih talijanskih jezikoslovaca koji su se bavili istraživanjem frazeologije (usp. Casadei 1996).
} 
Valja spomenuti i Luratijeve knjige Modi di dire. Nuovi percorsi interpretativi (1988), Dizionario dei modi di dire (2001) i Per modo di dire... Storia della lingua e antropologia nelle locuzioni italiane ed europee (2002) koji se „doduše ograničavaju samo na uobičajene izreke te time ne teže za potpunošću, ali zato prvi put pokušavaju svaku pojedinu izreku na odgovarajući način objasniti i usporediti je s njezinim dijalektalnim varijantama i ekvivalentima u drugim jezicima“ (Fanfani 2007, 983).

Binome kao specifičan tip frazema u talijanskome jeziku istraživala je Francesca Masini (2006) i Valentina Benigni (2012).

U poznatoj monografiji Phraseologie (2007) čiji su urednici Harald Burger, Dmitrij Dobrovol'skij, Peter Kühn i Neal R. Norrick priloge o talijanskoj frazeologiji napisali su Stefania Nuccorini, i to na engleskome pod naslovom Italian phraseology (2007). Prilog na njemačkome o historijskoj frazeologiji pod naslovom Historische Phraseologie des Italienischen napisao je Ottavio Lurati (2007), a prilog o talijanskoj frazeografiji Phraseographie des Italienischen napisao je na njemačkome Massimo Fanfani (2007).

No veliko zanimanje za frazeologiju pokazuje i utemeljenje talijanske udruge za frazeologiju i paremiologiju Phrasis, koja promiče frazeološka istraživanja i kongrese u Italiji i inozemstvu, potiče suradnju s institucijama i udrugama, suradnju među znanstvenicima $u$ Italiji i Europi i na drugim kontinentima, objavljuje bilten, a podupire i tiskanje publikacija posvećenih frazeološkim i paremiološkim istraživanjima.

Godine 2017. objavljen je zbornik Fraseologia e Paremiologia. Passato, presente e futuro čiji je urednik Cosimo de Giovanni. U njemu su objavljeni radovi na talijanskome, njemačkome, španjolskome, francuskome i portugalskome jeziku. Radovi su proistekli iz izlaganja na kongresu udruge za frazeologiju i paremiologiju Phrasis održanome od 16. do 18. rujna 2015. u Cagliariju. Cilj toga zbornika bio je da ,ponudi panoramski pregled teorijskoga i povijesno-evolutivnoga prikaza frazeologije i paremiologije“ (De Giovanni 2017, 13), što je zacijelo iskorak $\mathrm{u}$ tome smislu, premda ne postoji zajednička metodologija ni pristup frazeologiji jer je ,svaki prilog izraz perspektive koja je primijenjena na vlastitome istraživačkom polju i pristupa koji su znanstvenici primjenjivali istražujući frazeologiju i paremiologiju, baveći se, već prema tome, sinkronijskim ili dijakronijskim istraživanjima“ (isto). 
Udruga Phrasis organizirala je i kongres 2016. godine u Firenci, 2017. godine u Bukureštu, 2018. godine u Cataniji i 2019. godine u Rimu.

Valja napomenuti da na tim kongresima sudjeluju frazeolozi i paremiolozi iz cijeloga svijeta i da im se tako pruža mogućnost susreta i suradnje. Na kongresu u Cagliariju sudjelovali su frazeolozi iz Francuske, Italije, Španjolske, Njemačke, Austrije, Engleske, Rusije, Poljske, Slovačke, Rumunjske, Ukrajine i Brazila, što svakako upućuje na važnost koja se pridaje frazeološkim i paremiološkim istraživanjima (usp. De Giovanni 2017, 13).

Objavljen je također i zbornik Fraseologia, paremiologia e lessicografia (2018) koji se sastoji od radova 3. kongresa talijanske udruge za promicanje frazeologije i paremiologije Phrasis kao i zbornik radova Fraseologia e paremiologia: prospettive evolutive, pragmatica e concettualizzazione (2019), posvećen također frazeološkim i paremiološkim temama, vrlo sličan prethodnim zbornicima. 


\section{DEFINICIJA FRAZEMA}

Frazem ili frazeologizam jedan je od temeljnih pojmova frazeologije, odnosno predmet proučavanja frazeologije i ponajprije „osnovna jedinica frazeološkoga jezičnog sustava“ (Menac 2007, 11).

Bilo je potrebno dugo vremena da se taj termin ustali. U prvim desetljećima razvoja frazeologije vladao je terminološki kaos.

Je li posrijedi „terminološka raznolikost (zli jezici tvrde da je posrijedi pomutnja!)“(Palm 1997, 2) ili je to uistinu bio kaos, prosudba ovisi o mnoštvu čimbenika i stajalištu s kojega promatramo razvoj frazeologije, odnosno njezinu složenost i specifičnost $u$ jezikoslovlju.

O terminologiji ponajprije ruskih, potom njemačkih, a onda hrvatskih i talijanskih frazeologa mogla bi se napisati cijela knjiga. Ovdje ćemo se ograničiti na neke bitne crte, s naglaskom na njemačku frazeologiju koja je u tom pogledu imala najburniji razvoj.

U germanističkim istraživanjima moglo se naići na termine kao komplexe Einheit, Wortzusammenstellung, geformter Wortblock, autonomes Syntagma, vorgeformte Sprachwendung, Redeweise, Phraseologismus, phraseologische Einheit, Fertigbauteil, fixiertes Wortgefüge, Idiotismus, Formel, erstarrte Fügung, Gebrauchsmetapher (usp. Chrissou 2000, 12).

Christine Palm (1997, 2) uz Phrasem spominje i nazive kao Phraseolexeme, ${ }^{22}$ Wortgruppenlexeme, feste Wendungen, Redensarten.

Elke Donalies $(2009,30$ - 31) spominje različite pojmove, ovisno s kojega stajališta pristupamo - polileksikalnost, ponavljanje (učestalost), sintaktička anomalija, idiomatičnost i verbalizacija pojma:

„Polylexikalität: Phrasem, Phraseologismus, Phrase, Frasmus, Satzlexem, syntaktische Gruppe, Syntagma, Wortgruppe, Wortfügung, Wortverknüpfung;

\footnotetext{
${ }^{22}$ Definicija frazema / frazeologizma, koji slove kao općeprihvaćeni pojmovi, u jednojezičnome rječniku njemačkoga „Duden“ još se može pronaći pod natuknicom Phraseolexem: „phraseologische Einheit, die durch Idiomatizität, Stabilität und Lexikalisierung gekennzeichnet ist (z.B.: jemandem platzt der Kragen)“ <https://www.duden.de/rechtschreibung/Phraseolexem> (10.9.2018.); pod natuknicom Phrasem ne pojavljuje se ništa, a pod Phraseologismus samo uputa na Idiom (2). <https://www.duden.de/rechtschreibung/ Phraseologismus $>$ (10.9.2018.). Sve to upućuje na činjenicu da se frazeološka terminologija još u potpunosti nije izbistrila, odnosno da će se neki pojmovi, poglavito zbog novih pristupa frazeologiji još neko vrijeme zadržati.
} 
Wiederholung / Frequenz: Kollokation, Kookkurrenz, Redensart, Gemeinplatz, Formel, Leerformel, Floskel, Stereotyp, Klischee, Gebrauchsmetapher, automatisierter Redeteil;

syntaktische Anomalie: feste Wortgruppe, feste Verbindung, festes Syntagma, festgeprägter Satz, fixiertes Wortgefüge, stehende Redewendung, Fertigbauteil, autonomes Syntagma;

Idiomatizität: Idiom, Idiomatismus, idiomatische Wendung, idiomatische Phrase, idiomatische Lexemkette;

Versprachlichung eines Begriffs: Phraseolexem, Wortgruppenlexem, phraseologische Einheit““. Međutim priznaje da su „u njemačkoj frazeologiji prihvaćena dva kompaktna i dohvatljiva termina koji se također internacionalno rabe: frazem i idiom“ (Donalies 2009, 31). ${ }^{23}$

Ti pojmovi na neki način u sebi sažimlju veći dio istraživanja i mnoštvo pristupa najprije ruskih, potom njemačkih frazeologa (i ostalih koji su pisali na njemačkome) i može ih se držati svojevrsnim podsjetnikom dugoga i mukotrpnoga puta frazeologije kao znanosti od Ballya do danas.

Uz nužnu jasnoću definiranja i omeđivanja područja istraživanja frazeologije njihovo postojanje ili pak podsjećanje na faze njihove uporabe pridonose dubljem pronicanju u sve ono što danas tek olako nazovemo frazeologijom i frazemom. ${ }^{24}$

U hrvatskoj literaturi uz frazem rabili su se i drugi nazivi kao primjerice okamenjeni izraz, okamenjeni sklop, idiom, idiomatska fraza, ustaljeni izraz, ustaljena kolokacija, ustaljena fraza, frazeološka jedinica, frazeologizam, frazeologem, idiom itd. (usp. Vidović Bolt 2011, 17).

Međutim, ne možemo se priključiti gore spomenutome zaključku za njemački jezik da su općeprihvaćeni pojmovi: frazem i idiom.

\footnotetext{
${ }^{23}$ Upravo to terminološko bogatstvo zorno pokazuje svu složenost, slojevitost i bogatstvo frazeologije, sve „konotacije“ frazema, već prema tome s kojega stajališta mu pristupamo.

${ }^{24} \mathrm{Ne}$ zaboravimo pak, frazem jest i frazeoleksem i idiomatski leksemski niz, on je i čvrsta sveza riječi i čvrsta sintagma, on je i sintaktička skupina i autonomna sintagma, pojavljuje se i kao binom, somatizam, animalizam i biblizam, kao nacionalizam, internacionalizam ili interfrazeologizam, nastaje i nestaje, od drevne anatolijske i hetitske frazeologije preko latinske i grčke oplemenjene hebrejskom i aramejskom biblijskom frazeologijom, slavenske, romanske i germanske, čuva i konzervira zastarjelice i arhaizme, nekrotizme i frazeološki vezane sastavnice u jeziku, no istodobno unosi i novotvorenice, oživljuje jezik, prenosi znanje i iskustvo drugih jezika kroz frazemske kalkove ili polukalkove, ulazi u ,integracije“ kao interfrazeologizam, ali i izlazi iz njih, bori se s običajima i modama. Najprije ga forsiraju potom stigmatiziraju, no svejedno, iako mutira, frazem ostaje sebi dosljedan i u svako vrijeme i uz svaku modu i jezičnu politiku sebi nađe oduška i razmaše se sad u pisanome sad u govornome jeziku. Bez frazema teško je moguće zamisliti ono što nazivamo duhom jednoga jezika. Ostaje veliko pitanje hoće li se ikada tu specifičnu pojavu u jeziku moći svesti samo na jedan pojam, unatoč našemu uvjerenju da su definicije i jasna terminologija nužne za napredak svake znanosti.
} 
$\mathrm{U}$ hrvatskome frazem jest općeprihvaćeni pojam; idiom u značenju frazema koji je potpuno idiomatski još je dobrim dijelom nepoznat.

U talijanskome jezikoslovlju najčešće ćemo naići na pojam modo di dire, espressione fissa, espressione idiomatica, locuzione, međutim u posljednje vrijeme sve se više spominje i pojam fraseologismo čak gdjedgje i frasema, te prema španjolskoj tradiciji, unità fraseologica. ${ }^{25}$ Naziv jezikoslovne discipline fraseologia odavno je ustaljen kao i pridjev fraseologico - ,relativo alla fraseologia: dizionario fraseologico“. ${ }^{26}$ Terminologija nije jedinstvena ni općeprihvaćena i uz zamjetan utjecaj španjolske i njemačke frazeološke terminologije još je u fazi nastanka.

Probleme vezane za terminologiju spominje i Burger $(2005,38)$. Pokušalo se pri izradbi nove monografije Phraseologie dogovoriti oko jedinstvene terminologije. Međutim, pokušaj je propao jer uobičajeni su pojmovi u pojedinim jezicima duboko ukorijenjeni i opiru se bilo kakvomu pokušaju izjednačavanja.

Premda su definicije nužne kako bi se na neki način omeđilo područje istraživanja frazeologa i kako bi pojmovi bili jasniji, možemo reći da je frazem, danas u njemačkome i hrvatskome jezikoslovlju općeprihvaćen pojam, sve ono što izriču i svi gore spomenuti pojmovi na više jezika.

Frazemi su, prema Hrvatskoj enciklopediji „ustaljeni višečlani izrazi u jeziku koji se u govoru reproduciraju kao cjelina i kod kojih značenje nije zbroj značenja pojedinih sastavnica, npr. jabuka razdora, baciti koplje u trnje, ići grlom u jagode, prevesti žedna preko vode i sl.“.27

Prema Burgeru $(1982,1)$ frazeološka je ,sveza dviju ili više riječi onda kada (1) riječi grade jedinicu koja se ne može posvema objasniti sintaktičkim i semantičkim regularnostima povezivanja i kada se (2) ta sveza riječi u jezičnoj zajednici rabi slično kao leksem“.

Frazemi su gotove, cjelovite jedinice koje su ,govorniku unaprijed poznate, na neki način zadane: on ne bira sastavnice, nego gotovu svezu“ (Menac 2007, 9).

\footnotetext{
${ }^{25}$ Međutim, i u španjolskome jeziku u početku je vladao terminološki kaos i pojavljivalo se mnoštvo izraza kao primjerice: 'dicho', 'expresión hecha', 'fórmula', 'frase hecha', 'frase fija', 'frase proverbial', 'proverbio', 'giro', 'giro idiomático', 'locución', 'locución idiomática', 'modismo', 'refrán', 'adagio', 'aforismo', 'sentencia', 'máxima', 'modos de hablar' (usp. Sciutto 2005).

${ }^{26}<$ https://www.garzantilinguistica.it/ricerca/?q=fraseologico $>$ (15.6.2019.).

$27<$ http://www.enciklopedija.hr/natuknica.aspx?id=20523> (15.6.2019.).
} 
Prema Ljiljani Kolenić (1999) ono što je bitno za određivanje frazema jest: „1. sveza najmanje dviju riječi, 2. postojanost sveze (gotov oblik), 3. preobrazba značenja frazemskih sastavnica, 4. uklapanje u kontekst“.

Matešić precizira da je frazem ,jedinica jezika koja se reproducira u govornom aktu i raspolaže najmanje dvjema punoznačnim riječima, od kojih je barem jedna dobila novo značenje i koja (jedinica) u rečenici može vršiti sintaktičku funkciju“ (1996, 174).

Dakle, posrijedi su višerječne sveze koje su grafički odvojene. Inače ne možemo govoriti o frazemu. U nekim jezicima u kojima je uobičajeno stvaranje složenica, kao primjerice u njemačkome, to itekako može utjecati na odluku je li posrijedi frazem ili samo složenica. „Schwarzer Markt" u njemačkome je frazem, a „Schwarzmarkt" naprotiv nije i tradicionalno se pripisuje tvorbi riječi (usp. Donalies 2009, 7). Jasno je da i pravopis može utjecati na odluku što frazem jest, a što nije.

Posrijedi su jezični znakovi koji imaju svoje značenje (sadržaj) i formu (izraz).

Frazemi su u prvome redu ponavljanja, reproduciranja - inače nisu posrijedi frazemi. Mnogi su to povezivali s klišejima i otrcanošću, što je svakako pridonijelo nedovoljnom stupnju objektivnosti u pristupu frazeologiji.

Iako su višerječni, polileksikalni frazemi predstavljaju samo jedan pojam, jedan unos ili lemu u mentalnome leksikonu i to ih razlikuje od slobodnih sveza.

Leksički su binomi primjerice identični ,sa strukturnoga stajališta običnim koordinativnim sintagmama“ (Benigni 2012, § 7.1.), premda u odnosu na njih pokazuju veće restrikcije i sa sintagmatskoga i s paradigmatskoga stajališta, ali ih upravo jedinstvena semantika razlikuje od sintagmi.

Ako je u početku frazeoloških istraživanja „okamenjenost“" određenih sveza privukla pozornost jezikoslovaca i probudila uopće zanimanje za to područje jezika, danas je također važna spoznaja da nisu posrijedi značajke koje se povezuju samo s frazemima.

Ponavljanje i reproduciranje nije tipično samo za frazeologiju nego za jezik uopće. S time u svezi Donalies $(2009,12)$ kaže: „Gotovo sve se u jeziku, manje ili više ponavlja, reproducira. Inače se ne bismo mogli sporazumjeti. U skladu s time kod frazema nisu posrijedi bilo kakva ponavljanja, nego ponavljanja određenih sveza“. 
Frazemi su uglavnom sintaktički normalni, što je dugo vremena također stavljano u pitanje. Nije ih baš moguće definirati preko ,anomalije sintaktičke fiksiranosti“ (Donalies 2009, 19). Njihova „semiotička neupadljivost“ (Hallsteinsdóttir; Farø 2006, 3) čini ih katkad teško prepoznatljivima.

Mogu biti idiomatski, ali ne moraju. I to je također odlika koja se dugo vremena usko povezivala s definicijom frazema.

Načelno su frazemi arbitrarni jezični znakovi. Ta načelna arbitrarnost ,idioma znači da veza između označitelja i označenoga nije nužna, potrebna, nego čisto konvencionalna“ (Hallsteinsdóttir; Farø 2006, 4).

Budući da su posrijedi „znakovi sekundarne nominacije“(Wotjak 1992, 33), frazemi se sastoje od sastavnica koje kao samostalne riječi ili slobodne sveze ,imaju (imale su) već vlastito značenje“ (Hallsteinsdóttir; Farø 2006, 4), ne čudi da su frazemi po svojoj naravi višeznačni.

Osim toga, u frazeologiji se već duže vremena zastupa mišljenje da su frazemi sekundarni semiotički sustav jer s jedne strane „sastoje se od znakova primarne razine, a s druge strane kao sveze riječi stvaraju novu semantičku razinu“ (Burger 2005, 31 - 32).

Häcki Buhofer zaključuje na temelju najnovijega razvoja u frazeologiji da na temelju spoznaja u frazeološkim istraživanjima treba proširiti definiciju jezika. Prema tome jezik se ne bi raščlanjivao na dvije, nego na tri razine. Dvostruka artikulacija koja je jedan od temeljnih pojmova Martinetove funkcionalne lingvistike trebala bi se proširiti kao trostruka artikulacija: uz 1) sustav fonema i grafema koji razlikuju značenje te 2) sustav pojedinih znakova koji nose značenje trebalo bi dodati 3) sustav kombinatornih znakova - frazema koji se sastoje od više pojedinih znakova: znakova koji imaju posebnu kompleksnost i glede izraza i sadržaja i s time u svezi imaju karakteristični potencijal (usp. Burger 2005, 32).

Prema Burgeru to proširenje jezičnoga modela može se opravdati i ,s jedne strane semiotičkim, a s druge strane psiholingvističkim promišljanjima“ (Burger 2005, 32), a brojna istraživanja pokazuju da frazeologija „u velikoj mjeri pridonosi ekonomiji jezika“ (isto).

Sve nas to potiče na pomnjivije promišljanje o temeljnim odlikama frazema kako bismo s više jasnoće mogli reći što frazemi uistinu jesu i osloboditi se onih uvjerenja, pa čak i predrasuda koje desetljećima zamagljuju stvarnu narav frazema i frazeologije kao jezikoslovne discipline. 
Glede klasifikacije frazema, također vlada veliko nesuglasje.

Frazemi su nastali „na različite načine i pridošli iz različitih izvora, koji svi zajedno na specifičan način zrcale i ilustriraju tip mišljenja, odnos prema stvarnosti, povijesne reminiscencije, povezanost s okolnim svijetom i još mnogo toga što je za jednu jezičnu zajednicu karakteristično“ (Menac 2007, 15 - 16).

Glede samoga podrijetla frazema možemo ih podijeliti na nacionalne i posuđene frazeme (usp. Menac 1978).

Burger (1973, 75) navodi klasifikaciju prema morfosintaktičkim defektima i anomalijama, a Dobrovol'skij i Piirainen (1997) prema kulturno-semiotičkim kriterijima.

Frazeme se može tipologizirati prema „morfosintaktičkima, semantičkima, morfosintaktičko-semantičkima kao i kriterijima koji potječu od leksika“ (usp. Korhonen 2002).

Morfosintaktički ih možemo podijeliti na glagolske, imenične, pridjevne i priložne frazeme.

Semantički ih možemo podijeliti na idiomatske, djelomično idiomatske i neidiomatske frazeme (usp. Burger 2015, 27).

Budući da su se najrazličitije istraživačke discipline i različite jezikoslovne discipline bavile i bave se frazeologijom, sve je to dovelo do „divergentnih razgraničenja cijeloga područja i još više divergentnih klasifikacija i terminologija za glavne kategorije, a još i više za specifične tipove“ (Burger 2015, 37).

U svome djelu Frazeologija suvremenoga njemačkog jezika (1997) Fleischer navodi različite klasifikacije frazema u suvremenome njemačkom jeziku i različite kriterije prema kojima je klasifikacija izvršena. Tako spominje E. Agricolu i njegovu klasifikaciju prema semantičkim kriterijima, klasifikaciju I. I. Černyševe, U. Fixa, A. Rotkegela (usp. Fleischer 1997, 111 - 122). Dakle, u nekim klasifikacijama na prvome mjestu stoje semantički kriteriji, u drugima sintaktički, neki obrađuju frazeme koji prelaze granicu riječi, ali ne i rečenice (usp. Fleischer 2007, 110 - 123). 
Burger upozorava primjerice na različitu uporabu pojma „collocation“ $u$ anglosaksonskome jezičnom području koji često pokriva „cijelo područje frazeologije“ (2005, 37). U njemačkome se kolokacija rabi samo za jedan određeni dio frazema.

U novijoj se frazeološkoj literaturi uglavnom spominje da je glede klasifikacije frazema ipak postignuto određeno suglasje i da većina frazeologa za klasifikaciju frazema rabi kombinaciju sintaktičkih, semantičkih i pragmatičkih kriterija (njem. Mischklassifikationen).

Ovdje ćemo u kratkim crtama spomenuti klasifikaciju frazema prema kriteriju triju glavnih funkcija znakova koje frazemi imaju u komunikaciji. Burger (2015, § 2.2.) dijeli frazeme na referencijalne, strukturne i komunikativne.

Referencijalni frazemi odnose se na ,predmete, događanja ili činjenična stanja stvarnosti (bio to 'stvarni' svijet ili fiktivni svjetovi)“ (isto).

Dijele se prema semantičkome kriteriju na nominativne i propozicionalne frazeme. Paralelno s ovom dihotomijom postoji i sintaktička podjela: na frazeme prve skupine koji imaju vrijednost dijela rečenice (njem. satzgliedwertig) i propozicionalne frazeme koji imaju vrijednost rečenice odnosno teksta (njem. satzwertig).

Referencijalne frazeme ispod razine rečenice (nominativne frazeme) može se semantički podijeliti prema stupnju idiomatičnosti na idiome, djelomične idiome i kolokacije.

Osim toga, za podjelu nominativnih frazema potrebno je navesti još nekoliko sintaktičkih pojmova: dijele se na glagolske, imenične, pridjevne i priložne frazeme (njem. verbale, nominale, adverbiale und adjektivische Phraseme).

Propozicionalne frazeme (frazeme koji imaju vrijednost rečenice) moglo bi se podijeliti na temelju idiomatičnosti. U tome slučaju poslovice bi se moralo isključiti. Stoga se za temeljnu klasifikaciju uzima sintaktička i tekstnolingvistička podklasifikacija. Valja dakle razlikovati dvije skupine propozicionalnih frazema: „očvrsle (stabilne) fraze“ i ,topske formule“ (njem. feste Phrasen und topische Formeln). Topske formule dalje se dijele na poslovice i opća mjesta.

Funkcija strukturnih frazema bila bi stvaranje sintaktičkih odnosa koji pripadaju odgovarajućoj vrsti riječi i u sintaktičkome smislu može se govoriti o prijedložnim i vezničkim frazemima (njem. präpositionale und konjunktionale Phraseme), a komunikativni frazemi imali bi određene zadaće „pri proizvodnji, definiranju, izvršenju i okončanju komunikativnih djela“ (Burger 2015, 32). Komunikativni frazemi nazivaju se i rutinskim formulama. Oni uglavnom 
ispunjaju određene uloge u diskursu, kao primjerice pozdrav „Dobro jutro“ ili izraz „Bogu hvala" itd.

Burger drži da se ova germanistički usmjerena temeljna klasifikacija za proučavanje i pregled „frazeoloških pojava u tekstu već pokazala korisnom“ $(2015,37)$ i ona bi mogla biti poticajem i polazištem pri izradbi klasifikacije osobito za talijanski jezik i daljnjoj doradi klasifikacije za hrvatski jezik. 


\section{TEMELJNA OBILJEŽJA FRAZEMA}

Određivanje temeljnih obilježja frazema $u$ frazeološkoj literaturi zauzima dosta prostora. To je svakako važna tema ponajprije stoga jer se time polažu temelji svim daljnjim istraživanjima, odnosno jasno se određuju granice između slobodnih i frazeoloških sveza riječi.

U hrvatskoj frazeološkoj literaturi naići ćemo ,uglavnom na vrlo bliska stajališta o frazemima“"(Opašić 2013, 47).

U frazeološkoj literaturi osobito na njemačkome jeziku „kriteriji koji svezu riječi određuju kao frazeološku odnosno slobodnu vrlo su heterogeni““(Chrissou 2000, 16).

Kako smo i dosad spominjali, s obzirom na to da je frazem vrlo složena pojava koja duboko prodire u bit svakoga jezika, a budući da je k tome riječ o jedinicama koje su sekundarno nastale te na osobit način ostaju povezane s više različitih razina, to sve djeluje i na sam sastav frazema u različitim jezicima u kojima različita morfologija, sintaksa i semantika na svoj način pridonose i ,izgledu“ samoga frazema. To je osobito važno uzeti u obzir prilikom supostavne raščlambe frazema jezika koji genetski nisu srodni.

Dakle, jedinstvene i općeprihvaćene definicije o tome što je frazem trenutačno nema jer „postoje velike razlike u definicijama što ih za frazeologizam daju pojedini autori““ (MuhvićDimanovski 1992 - 1993, 323).

Chrissou $(2000,17)$ drži da se pri određivanju temeljnih obilježja frazema ne smije iz vida izgubiti razlika između „frazeološkoga centra (frazemi) i perifernoga frazeološkog područja (frazeologizmi i frazeološke jedinice)“ i pri tome valja razlikovati „obligatna i fakultativna“ (isto) obilježja frazema.

Iako su kriteriji heterogeni, svakako nam mogu pripomoći u određivanju što uglavnom jest frazem u jednome jeziku, a što nije, barem na temelju kriterija koji su dosad u znanosti slovili kao pouzdani. ${ }^{28}$

Matešić (1995, 84 - 85) govori o relevantnim obilježjima frazema i u njih ubraja reproduciranje, formalno ustrojstvo, idiomatičnost i uklapanje u rečenicu.

\footnotetext{
${ }^{28}$ To su uglavnom kriteriji koji su slovili kao općeprihvaćeni u frazeografiji prilikom sastavljanja frazeoloških rječnika koji su nam poslužili za stvaranje korpusa za drugi dio rada, kontrastivnu raščlambu frazema biblijskoga podrijetla u talijanskome i hrvatskome jeziku.
} 
Vidović Bolt, sažimajući bogatu tradiciju Zagrebačke frazeološke škole zaključuje da su osnovna obilježja frazema: ,relativno čvrsta struktura, nepodudarnost značenja s leksičkim značenjem frazemskih sastavnica, ustaljenost, reproduktivnost, tj. dugotrajna prisutnost ustaljene i čvrste veze u govoru veće skupine ljudi i to u neizmijenjenom obliku i sastavu, desemantiziranost i slikovitost, ekspresivnost i konotativno značenje i otežana mogućnost prevođenja dijela frazema“ $(2011,19)$.

Mi ćemo se na osobit način pozabaviti polileksikalnošću (višerječnošću), ustaljenošću (stabilnošću strukture, čvrstoćom), idiomatičnošću te leksikaliziranošću i reproduktivnošću kao temeljnim značajkama frazema kako bismo, osobito na temelju suvremenih istraživanja (usp. ponajprije Burger 2015 te Chrissou 2000, Richter Vapaatalo 2007, Donalies 2009 itd.) dublje prodrli u strukturu frazema, nastojeći se pri tome ne izgubiti u moru različitih stavova, mišljenja i pristupa. ${ }^{29}$

Ovdje je važno spomenuti, budući da je riječ o kontrastivnoj usporedbi dvaju indoeuropskih jezika (dakle ipak genetski srodnih u širemu smislu) koje imamo u vidu u ovome teorijskom dijelu uz usporedbu $\mathrm{s}$ istraživanjima $\mathrm{u}$ njemačkome jeziku te kontrastivnim istraživanjima njemačkoga s drugim indoeuropskim jezicima, da postojanje svojevrsne sličnosti u morfologiji (flektivni jezici) i sintaksi, uz određene tipološke sličnosti, pridonose tomu da temeljne značajke frazema ne predstavljaju posebne probleme. Tu svakako valja uključiti i razmatranja o još nedokazanome postojanju frazeoloških europeizama. Bilo kakvi zaključci o temeljnim obilježjima frazema, dakle o neslobodnim svezama riječi koje nazivamo frazeološkima, odnosile bi se poglavito na gore spomenute jezike. Kontrastivne usporedbe s drugim jezicima, osobito neindoeuropskima i neeuropskima, dodatno će rasvijetliti i produbiti ta saznanja. Ne bi bilo čudno da mnoge od njih redefiniraju.

Dakle, onkraj genetske nesrodnosti, izuzev šire srodnosti u okviru indoeuropske jezične porodice, dodiri među europskim jezicima intenzivni su zbog mnoštva govornika koji su dvojezični ili čak i višejezični i stoga jezici poprimaju slična strukturna obilježja pa se mnogi

\footnotetext{
${ }^{29}$ Osobito je svima onima koji se bave supostavnom raščlambom slavenskoga i neslavenskoga jezika teško zauzeti čvrst stav o bilo kojemu obilježju jer se zbog razlika u morfologiji, sintaksi i tvorbi riječi mnoge temeljne značajke frazema drukčije promatraju. Isto je tako teško definirati što je prototipsko u frazeologiji. Primjerice, leksički su binomi jezična univerzalija i poznati su u mnogim jezicima: i u indoeuropskima, osobito germanskima i slavenskima, u manjoj mjeri i u romanskima, ali i u azijskim i novogvinejskim jezicima (usp. Luque Nadal 2017). Dok za hrvatski i slavenske jezike, ali i germanske i romanske jezike možemo reći da je binom prototipni oblik, a trinom rjeđa, dok se kvadrinomi iznimno rijetko pojavljuju, nerijetko samo u brojalicama i sl., u kineskome su primjerice frazeološki (često metaforični) kvardinomi velika skupina među frazemima (usp. Burger; Buhofer; Sialm 1982, 38).
} 
svrstavaju u saveze, a valja spomenuti i sličnosti tipoloških obilježja koja ne ovise ni o genetskome srodstvu ni o arealnim utjecajima.

I u suvremenim leksikološkim istraživanjima zamjetno je da „snažni međujezični kontakti djeluju u smjeru leksičke i frazeološke konvergencije. Djelomični lažni parovi mogu se semantičkim posudbama približiti ili čak postati pravi parovi““ (Ljubičić 2011, 176).

Ne smije se zaboraviti ni odavno prepoznata „,vagabundska narav frazema“ koji prelaze iz jednoga jezika i drugi, potom se udomaće u jeziku primatelju, a onda se katkad i dalje posuđuju.

Kalkiranje nije rijetka pojava u frazeologiji, štoviše ono je u biti ,vrlo često u frazeologiji“ (Ljubičić 2011, 176). A kalkiranjem iz jezika u jezik prenose se mnoga zajednička obilježja, mehanizmi i obrasci koji svakako utječu na veću sličnost frazema različitih jezika.

U talijanskome i hrvatskome frazeološkom blagu i to se mora uzeti u obzir jer su posrijedi dva susjedna jezika koja su više od tisuću godina u najužemu međusobnom dodiru, iako nisu genetski u bliskome srodstvu.

Uzmemo li u obzir ne samo standardni hrvatski jezik, nego i njegova narječja, na vidjelo izlazi drukčija slika jer su ,germanska i romanska komponenta zastupljenije u našim dijalektima nego u standardnome jeziku“ (Ljubičić 2011, 190).

Oba su jezika tipološki slična, a latinski jezik iz kojega je standardni talijanski jezik potekao imao je snažan utjecaj i na hrvatski jezik općenito. Zbog latinskoga prijevoda Biblije sv. Jeronima Dalmatinca koja se prevodila na hrvatski te zbog latinske liturgije u crkvama, ali i utjecaja latinske književnosti i rimskoga prava i retorike može se pretpostaviti da je utjecaj latinskoga na hrvatski i u oblikovanju frazeološkoga i paremiološkoga blaga bio velik. Ujedno, latinski je imao snažan utjecaj i na frazeologiju drugih jezika koji su imali jak utjecaj na hrvatsku frazeologiju, primjerice na njemački.

Sve to dovodi do zaključka da je posrijedi sličan tip frazeoloških jedinica i iako su izložene različitim utjecajima i silnicama, predstavljaju sličan tip frazema europskih jezika.

Dakle, da bismo govorili o frazemu, ne moraju biti ispunjeni svi gore spomenuti kriteriji. U pravilu, to moraju biti leksikalizirane višerječne jedinice relativno stabilne strukture. Mogu, ali ne moraju biti idiomatske. Idiomatičnost može biti i djelomična, a može i posve izostati. 
Napominjemo da prema Burgeru (2015, 14 - 15) razlikujemo pojam idiom od frazema: idiom nije sinonim za frazem, nego njegov podrazred i frazem je širi pojam od idioma. Jasno je da idiom, uz višerječnost i stabilnost strukture, mora biti i idiomatski, što za ostale frazeme nije odsudno. ${ }^{30}$

\subsection{Polileksikalnost}

Većina frazeologa zacijelo će se složiti da je polileksikalnost obilježje frazema koje se s pravom može definirati očitim: ona nam najprije upada u oči.

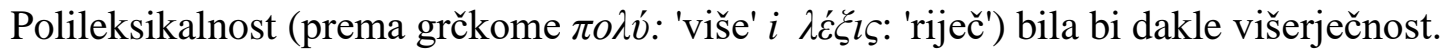

Prema Fink Arsovski $(2002,6)$ frazem se sastoji „,najmanje od dviju sastavnica (od dviju autosemantičnih ili od kombinacije autosemantičke i sinsemantičke riječi)“.

Donalies $(2009,7)$ zaključuje bez ikakve dvojbe: „Frazemi su polileksalni““. Dakle, sastoje se od više riječi, oni su višerječni. ${ }^{31}$

Ako nije višerječan, nije frazem. Pri tome, kao u njemačkome, pravopisni uzus može biti odsudan kriterij, no svejedno dobar kandidat za frazem mora biti višerječan. ${ }^{32}$

Kovačević $(2012,12)$ kaže da je frazem kao osnovna frazeološka jedinica „na planu izraza višeleksemsko jedinstvo, tj. složen znak kojemu odgovara jedno značenje“.

Burger (2015, 36) govoreći o mogućnosti ,jednorječnoga frazema“ (njem. Einwortphrasem $)^{33}$ napominje da mnoge složenice u semantičkome smislu imaju jasno srodstvo s frazeologijom. Neke riječi funkcioniraju kao idiomi. Leksikalizirane su i može ih se razumjeti metonimijski odnosno metaforično. Neke su složenice djelomično idiomatske, međutim unatoč toj semantičkoj srodnosti njih se ne uračunava $u$ frazeologiju. $U$ morfosintaktičkome smislu to su riječi, a ne frazemi. Međutim, poradi terminološke korektnosti

\footnotetext{
30 Burger $(2015,159)$ povijesni proces po kojemu slobodna sveza riječi postaje frazemom naziva frazeologizacijom, što je inače općeprihvaćeni pojam u frazeologiji. Međutim, proces po kojemu sveza riječi postaje idiomom naziva idiomatizacijom. Taj se pojam u našoj frazeološkoj literaturi dosad u ovome smislu nije rabio.

${ }^{31}$ Donalies spominje pojam schwarzer Markt kao frazem, za razliku od Schwarzmarkt koji je jedna riječ i time se tradicionalno pripisuje tvorbi riječi. Budući da je to samo jedna riječ, ne može biti frazem.

32 Donalies $(2009,8)$ spominje da su kriteriji komplicirani već u njemačkome, ali u drugim jezicima još kompliciraniji, primjerice girl friend ili red wine u engleskome za koje nije lako ustvrditi jesu li jedna riječ, složenica ili su posrijedi dvije riječi ili frazem.

${ }^{33}$ Primjerice Duhme (1995) govori o jednorječnim frazemima.
} 
„može se svakako govoriti o 'idiomatskim' ili 'djelomično idiomatskim' složenicama jer je 'idiomatičnost' semantička značajka koja se doduše uglavnom susreće u frazeologiji, ali koja se ne mora ograničiti na frazeologiju“ (isto).

I u hrvatskome postoji primjer frazemskih sraslica. ${ }^{34}$ Frazeološki ih rječnici „zbog formalnoga kriterija višerječnosti redovito isključuju iz frazeološkoga fonda, a opći ih rječnici rijetko uključuju“ (Kovačević; Ramadanović 2013, 272).

Dakle, polileksikalnost ili višerječnost predstavlja donju granicu frazeologije i pomaže tomu da se frazeme jasno odvoji od oblika koji pripadaju području tvorbe riječi.

Forma frazema sastoji se dakle od barem dviju sastavnica koje su odvojene prazninom. Ta praznina služi kao „distinktivno obilježje“ kod podjele leksika na frazeologiju i riječi (Hallsteinsdóttir; Farø 2010, 129).

Prema Fleischeru frazem je sveza riječi koja sadrži „,barem jednu autosemantičnu riječ“ $(1997,29)$.

Vidović Bolt također drži da je „frazem jedinica frazeološkoga jezičnog sustava koja se sastoji od najmanje dviju sastavnica, pri čemu jedna od njih mora biti punoznačnica““(Vidović Bolt 2011, 19).

Govoreći o donjoj granici polileksikalnosti Burger $(2015,15)$ kaže da se frazem sastoji od „dviju ortografski odvojenih riječi“, ali napominje da ne postoji suglasje oko toga je li riječ „o autosemantičnim ili sinsemantičnim riječima“. Budući da po njegovoj prosudbi ne postoje plauzibilni kriteriji ni za jedno ni za drugo mišljenje on „u frazeologiju uračunava svaku čvrstu kombinaciju dviju riječi, također i izraze kao an sich, bei weitem, wenn auch, im $\mathrm{Nu}$ “.

I Donalies drži različite stavove oko sastava frazema „zbunjujućima“ i kaže da je možda najbolje „sve ostaviti otvorenim“ te i ona drži sve „uobičajene sveze najmanje dviju riječi koje god vrste - frazemima“" $(2009,10)$.

Treba napomenuti da ne postoji jedinstvo ni oko gornje granice frazema. Ako je jasno da se frazem mora sastojati barem od dviju riječi, bile one isključivo samoznačnice, suznačnice

\footnotetext{
${ }^{34}$ Prema Kovačević i Ramadanović $(2013,272)$ frazemske su sraslice: ,jednorječne jezične jedinice u kojima je redoslijed sastavnica isti kao u sintagmi ili svezi riječi od kojih su nastale. Tvorbene su sastavnice okamenjene $u$ nekome obliku, a nova jedinica ima jedan naglasak, npr. budiboggsnama, akoboggda...“.
} 
ili jedna samoznačna i jedna suznačna riječ, ne postoji suglasje oko toga koliko se riječi smije povezati kako bi još uvijek spadale u frazem?!

Menac također naglašava da je najmanji opseg frazema „kad se sastoji od jedne samostalne i jedne pomoćne riječi, a najveći opseg frazema nije određen“" $(2007,15)$.

Higi-Wydler pretpostavlja da se frazemi sastoje „,barem od dviju riječi, ali su ipak manji od rečenice“" $(1989,55)$.

Višerječnost predstavlja dakle temeljnu formalnu razliku frazema prema riječima. Međutim, to ne dovodi do temeljne funkcionalne razlike: „rabe se kao 'normalni' jezični znakovi“ (Hallsteindottir 2011, 7).

Prema Donalies upitno je mogu li se i tekstovi koji su sveze više rečenica ,ubrojiti u frazeme“. Tomu valja pridodati i stihove i pjesmice koje se uče u školi koje su također „uvriježene (njem. usuell) sveze riječi“ (Donalies 2009, 10). Premda u frazeologiji nije posve jasna količina riječi koje se mogu ubrojiti u frazem, Burger drži rečenicu ,gornjom granicom frazeoloških sveza riječi“. Jasno i izreke, stihovi, molitve itd. mogu imati status „koji je usporediv sa statusom frazema ako ih ne uče naizust pojedine osobe, nego pripadaju jezičnomu blagu većih skupina, između ostaloga i cijelih pokoljenja“ (Burger 2015, 15).

Time što su višerječni, frazemi se s morfološkoga i sintaktičkoga stajališta ponašaju kao skupina riječi, međutim govornici ih pohranjuju kao jedan unos, jednu lemu. Polileksikalnost je svakako bitno pridonijela da se frazeme dugo vremena isključivalo iz ozbiljnih jezikoslovnih istraživanja jer je upravo višerječnost u kombinaciji s idiomatičnošću, fonološkim, morfološkim i sintaktičkim iregularnostima otežavala cjelovito promatranje frazema i dugo je vremena trebalo da se etablira holističko-integrativni pristup u proučavanju frazema kao i u njihovu prenošenju i načinu prenošenja izvornim govornicima i svima onima koji uče određeni jezik.

\subsection{Ustaljenost (stabilnost strukture, čvrstoća)}

Ustaljenost ili stabilnost strukture također je jedno od temeljnih obilježja frazema.

Dakle, riječ je o višerječnoj svezi riječi koja se sastoji najmanje od dviju sastavnica i koju „karakterizira cjelovitost i čvrsta struktura“ (Fink-Arsovski 2002, § 1.2.1.). 
Frazemi u pravilu imaju čvrstu, ustaljenu strukturu. U većini definicija frazema govori se upravo o ustaljenim višečlanim izrazima.

Njihova je struktura nerijetko čvrsta i frazemi se „reproduciraju u unaprijed određenom, gotovom obliku, tj. ne formiraju se svaki put iznova spontanim slaganjem pojedinih riječi kao što se formiraju slobodne sveze riječi“ (Menac 2007, 11).

Međutim, stabilnost strukture puno je teže razumjeti nego polileksikalnost (usp. Burger 2015, 16).

Ustaljenost (stabilnost) slovi kao „strukturni korelat idiomatičnosti“ (Chrissou 2000, 30).

Izmjena sastavnica u frazemu u pravilu je rjeđa i podliježe većemu broju ograničenja nego u slobodnim svezama riječi.

Kao prototip stabilnosti strukture možemo uzeti binome (trinome, kvadrinome) u suvremenome talijanskom, hrvatskom ili njemačkom te drugim europskim jezicima. Binomi su uglavnom sastavljeni od dviju riječi. Sastavnice binoma pretežno pripadaju istoj vrsti riječi ${ }^{35}$ koje povezuje ponajčešće sastavni veznik $i$. Slijed sastavnica u pravilu je strogo određen ili postoji barem preferencija za određeni slijed sastavnica. U suvremenim europskim jezicima obilježava ih u većem broju primjera potpuna idiomatičnost, dakle time i strogo ustaljena, stabilna struktura.

Primjerice

- u talijanskome: di riffa o di raffa; a occhio e croce; Tizio, Caio e Sempronio

- u hrvatskome: cakum-pakum; ni pet ni devet; čula, rekla, kazala

- u njemačkome: fix und fertig; gang und gäbe; Hinz und Kunz.

Luisa Giacoma ustaljenost frazema definira kao „resistenza che i fraseologismi offrono a sostituzioni lessicali“ (2017), navodeći kao primjer ulogu stabilnosti kako bi se razlikovali izrazi fare festa, fare una festa, fare la festa i fare le feste.

Frazeme stoga uglavnom učimo naizust i preuzimamo ih od starijih generacija, često ne razumijevajući značenje pojedinih riječi koje frazem čuva, a koje su dijalektalizmi, zastarjelice,

\footnotetext{
35 Sastavnice binoma mogu pripadati i različitim vrstama riječi, međutim to je uglavnom rijetka pojava (usp. Donalies 2015, 28).
} 
arhaizmi ili nekrotizmi. Često su posrijedi ,productos diacrónicos que han pervivido en el estado sincrónico actual de la lengua“ (Ruiz Gurillo 1997, § 5.1.2.).

Osim toga Ruiz Gurillo napominje: čvrstoća, „la fijación es un recurso general de la lengua“ (1997, § 5.1.1.). S time u svezi govori o ponavljanju kao o temeljnome mehanizmu stvaranja i razvitka ljudske kulture i jezičnih sustava: „La transmisión oral de padres a hijos de leyendas, mitos, etc., es decir, la repetición de textos, cumple una función destacada en el desarrollo de la cultura [...] Repetición de fonemas, repetición de sílabas, repetición de palabras, repetición de segmentos textuales, repetición de estructuras narrativas, ... suponen mecanismos lícitos en las lenguas naturales, encaminados a la producción de efectos textuales, de juegos retóricos, de resultados expresivos” (Ruiz Gurillo 1997, § 5.1.1.1.).

Leksičko-semantička kao i sintaktičko-strukturna ustaljenost koje dobrim dijelom vrijede u frazeologiji jednoga jezika ipak predstavljaju ,relativne veličine“ (Chrissou 2000, 33). To vrijedi čak i za binome. U dijakronijskome smislu čak i za binome koji danas imaju očvrslu strukturu i koji su u najvećoj mjeri idiomatski. ${ }^{36}$

Palm upozorava da se kriterij stabilnosti ne smije shvatiti u ,apsolutnome smislu“ (1997, 29) jer postoje ,inačice mnogih frazema u sustavu“ (isto).

Burger (2015, § 1.3.), raspravljajući o stabilnosti strukture, govori najprije o „uporabnosti“, ${ }^{37}$ potom o psiholingvističkoj, strukturnoj i pragmatičkoj stabilnosti.

Uporabnost bi značila da je frazem ,u uporabi“ u sinkronijskome presjeku jezika. To znači da govornik toga jezika neposredno prepoznaje značenje toga frazema, a da ne poseže za potencijalnim doslovnim značenjem. Uporabnost se može odnositi na cijelu jezičnu zajednicu ili na određene dijelove koji se mogu odrediti arealno ili sociolektalno.

Manifestacija uporabnosti označava se kao ,'stabilnost' sveze riječi pri čemu se razlikuju barem tri razine promatranja“ (Burger 2015, 17).

Najprije se spominje psiholingvistička stabilnost koja se dokazuje na temelju psiholingvističkih testova. Psiholingvistički testovi pokazuju da su frazemi mentalno pohranjeni kao jedinice, slično kao riječi. Pri tome valja napomenuti da frazemi nisu

\footnotetext{
${ }^{36}$ Prema istraživanjima Haralda Burgera to nije bio slučaj u srednjovjekovnome njemačkom. Binomi nisu bili uvijek idiomatski i nisu imali stabilnu strukturu kao danas (usp. Burger 2012, 9).

${ }^{37}$ Njemački ,Gebräuchlichkeit““ (usp. Burger 2015, § 1.3.).
} 
„kompaktne jedinice kao riječi“ i da se često ponašaju kao „'normalne' sintaktičke tvorbe“ (Burger 2015, § 1.3.2.).

Za razliku od slobodnih sveza riječi, frazeološke sveze riječi često pokazuju nepravilnosti i razne restrikcije koje nadilaze normalne regularnosti. Sve te anomalije „simptomi su za 'idiomatičnost' frazema i time je strukturni vid stabilnosti ujedno i vid idiomatičnosti““(Burger 2015, § 1.3.3.).

Iregularnosti se mogu prepoznati u morfologiji i/ili sintaksi. Mnoge se odnose na „ranije odnose u jeziku i 'smrznute' su u starijemu obliku“ (Burger 2015, § 1.3.3.1.). Manje su brojne iregularnosti koje se tiču glagolske valencije.

Restrikcije mogu biti morfosintaktičke ili leksičko-semantičke.

Nakon promišljanja o stabilnosti u mentalnome leksikonu i u strukturi jezika, važno je spomenuti i perspektivu glede tipičnih usmenih i pismenih komunikacijskih situacija. Ta perspektiva može se nazvati ,pragmatičkom“. Ovdje možemo ubrojiti formule koje u nekoj situaciji imaju određenu funkciju kao pozdravi i ostale formule koje igraju ulogu poglavito u usmenoj komunikaciji (usp. Burger 2015, § 1.3.4.).

Glede stabilnosti strukture Burger $(2015, \S 1.3 .5$.) zaključuje da su „frazemi višerječne jedinice relativne stabilnosti. Frazemi su međusobno i s leksikonom riječi povezani na različite načine. Potrebna nam je dakle fleksibilna koncepcija frazeologije koja tolerira misao da se unutar frazema smije prihvatiti stabilnije i manje stabilne elemente i da granice prema slobodnim svezama riječi nisu čvrste“.

U kontekstu stabilnosti valja spomenuti i varijabilnost frazema te varijaciju i modifikaciju koje se danas uglavnom drže dvama ostvarajima varijabilnosti.

Varijabilnost frazema predstavlja „komplementaran pojam strukturnoj stabilnosti““ (Richter-Vapaatalo 2007, 46). Postoji samo malen broj frazema „koji su toliko čvrsti da ne pokazuju nikakvu varijabilnost“" (isto).

Varijacija predstavlja uvriježene (uzualne) pojavnosti, a modifikacija je „okazionalna preinaka jednoga frazema, načinjena za potrebe jednoga teksta“ (Burger 2015, 24).

Varijaciju i modifikaciju nije uvijek lako razgraničiti i često je to pitanje prosudbe istraživača. 


\subsection{Idiomatičnost}

Ponajprije, idiomatičnost nije vezana samo za frazeme, posrijedi je „fenómeno general del lenguaje“ (Ruiz Gurillo 1997, § 5.2.2.). Idiomatičnost je prema Casadei (1996, 28) „sinonimo da un lato di peculiare, dall'altro di genuino“.

Premda je već spomenuto da ne postoji opće suglasje o temeljnim obilježjima frazema i da su sama načela vrlo heterogena, a pristupi i tumačenja vrlo različiti, može se zamijetiti da je od svih obilježja frazema idiomatičnost tipično obilježje, tj. ono koje se na neki način najviše dovodi u vezu s frazeologijom i koje se ponajvećma spominje u literaturi.

Crissou kaže da se „ni kod kojega drugog načela za određivanje jedne sveze riječi frazeološkom u istraživanjima ne vlada takvo, gotovo pa posvemašnje suglasje kao za njegovu semantičku posebnost“ $(2000,19)$.

Frazem je idiomatski što ponajprije znači da njegovo značenje ne nastaje zbrojem značenja njegovih sastavnica. Odnos između značenja cijele sveze i pojedinih komponenti jest „iregularan“ (Fleischer 1997, 30). Pri tome semantički odnos u danome izričaju nije lako razumljiv. Među sastavnicama ne postoji „,semantička kongruencija“ (Fleischer 1997, 30).

Međutim, i sam pojam idiomatičnost različito se tumači u frazeološkim istraživanjima. U frazeologiji u širemu smislu idiomatičnost obuhvaća ,strukturne anomalije koje predstavljaju jedan vid 'stabilnosti', a s druge strane specifično semantičke značajke koje mnoge frazeme dovode u opreku sa slobodnim svezama“" (Burger 2015, 26).

U frazeologiji u užemu smislu idiomatičnost se drukčije shvaća. Ona predstavlja samo „semantičke vidove“, premda se i semantičke posebnosti jednoga frazema mogu promatrati jednim „vidom 'anomalije', tako da bi idiomatičnost u širemu smislu uvijek zahtijevala neki oblik anomalije“ (Burger 2015, 26).

Burger, inače predstavnik frazeologije u širemu smislu, idiomatičnost shvaća „u užemu smislu 'semantične idiomatičnosti'“ (isto).

Dakle, i sam pojam idiomatičnost sporan je u frazeologiji. Neki već stavljaju u pitanje treba li se idiomatičnost uopće promatrati „središnjim načelom“ (Donalies 2009, 22). Sporno je također i to treba li idiomatičnost držati „,suprotnošću doslovnomu značenju“. Nije također jasno što bi trebalo predstavljati ,doslovno značenje na kojemu se temelji kriterij idiomatičnosti“. Ne postoji ni suglasje oko toga imaju li riječi „prava, prirođena, izvorna, 
naravna, doslovna značenja“ (Donalies 2009, 22). Pri tome se možemo pozvati samo na rječnike koji sugeriraju da ,postoji nešto kao 'doslovna' značenja, i to upravo ona koja su navedena $u$ rječniku i koja su ograničena jedna od drugih“ (Teubert 2004 prema Donalies 2009, 22).

Prema Donalies također je sporno je li kriterij idiomatičnosti uopće prikladan za „razgraničenje frazema od ostalih fenomena“. Prema suvremenim istraživanjima, a u tome postoji već široko suglasje, idiomatičnost nije samo tipična „za frazeme, nego je opća pojava u jeziku“ (Donalies 2009, 25).

Procesi metaforizacije i metonimizacije uglavnom dovode do stvaranja idiomatičnosti. Frazemi se „mogu (sinkronijski i dijakronijski) svesti na slobodne sintagme čiji se sadržaj apstrahiranjem s konkretne situacije prenosi na drugi denotat" (Chrissou 2000, 22). Što je frazem više idiomatski, to je manja motiviranost.

Prema stupnju idiomatičnosti frazeme se može podijeliti na posvema idiomatske $\mathrm{i}$ djelomično idiomatske (usp. Palm 1997, 12).

S time u svezi Fink-Arsovski $(2002,6)$ govori da je uz karakterističnu slikovitost koja se „odražava u dubinskoj strukturi frazema, u tzv. semantičkom talogu“, za većinu frazema nastalih na bazi slobodnih sveza direktno vezana i ,desemantizacija (semantička preoblika, semantička pretvorba) svih ili dijela frazeoloških komponenata (sastavnica) u frazemu“ (isto). Razlikujemo dakle potpunu i djelomičnu desemantiziranost.

Burger $(2015,27)$ prema užemu shvaćanju idiomatičnosti kao izričito semantičke idiomatičnosti razlikuje potpuno idiomatske, djelomično idiomatske i neidiomatske frazeme (njem. vollidiomatisch, teilidiomatisch und nicht idiomatisch).

a) Ako je frazem potpuno idiomatski, ${ }^{38}$ ako su sve sastavnice semantički preoblikovane, dolazi dakle do semantičke preoblike i pomaka u značenju. Taj tip frazemā prema Burgeru naziva se idiomima, a proces koji dovodi do njihova stvaranja idiomatizacijom (usp. Burger 2015, 15). Sastavnice idioma ne mogu se razdvajati i nemaju smisla ako se rabe odvojeno.

b) Ako jedna ili više sastavnica zadržava svoje prvotno značenje, posrijedi su djelomično idiomatski frazemi. Premda neke sastavnice nisu doživjele semantičku preobliku,

\footnotetext{
${ }^{38}$ U literaturi na hrvatskome jeziku Melvinger $(1989,97)$ donosi podjelu na idiome, odnosno idiomatske fraze, frazeološke sveze i frazeološke izraze. Maček (1992 - 1993) je predlagala da se umjesto pojma frazem rabi pojam idiomatska fraza, što se pak bitno razlikuje od Burgerova pristupa i klasifikacije.
} 
dijelom su frazeološke sveze. Takvi djelomični idiomi sastoje se od potpuno idiomatskih i slobodnih sastavnica.

c) Osim potpuno idiomatskih i djelomično idiomatskih frazema postoji i treća skupina frazeoloških sveza koje nisu idiomatske. U tim svezama postoji nikakva ili malena diskrepancija između slobodnoga i frazeološkoga značenja.

Burger $(2015,13)$ za razliku od uvriježenih pojmova doslovno i preneseno značenje (njem. wörtliche und übertragene Bedeutung) uvodi pojmove slobodno i frazeološko značenje (njem. freie und phraseologische Bedeutung).

Uz pojam prenesenoga značenja drži da je pojam frazeološko značenje prikladniji jer „već prema surječju i pitanjima koja se postavljaju - može označiti i značenje cijeloga frazema kao i značenje pojedinih sastavnica unutar frazema. Osim toga pojam ne implicira pretpostavke o specifičnome značenju odnosnoga frazeološkog značenja. Upravo ondje gdje postoje samo slabi odmaci od doslovnoga značenja (kao u Dank sagen) pojam 'preneseno značenje' bio bi previše jak“ (isto).

Budući da se ne nudi bolji pojam od pojma „doslovno značenje“, Burger ga preuzima iz općega jezika. Međutim, kad valja naglasiti da se jedna sastavnica frazema pojavljuje u „slobodnoj“ uporabi i u tome slučaju ima određeno značenje, Burger rabi pojam „slobodno značenje“" (Burger 2015, 14).

Dakle, u skladu s kriterijem semantičke idiomatičnosti, postoje različiti odnosi između frazeološkoga i slobodnoga značenja sastavnica cijele frazeološke sveze.

Ako postoji nesuglasje između frazeološkoga i doslovnoga značenja cijeloga izraza, posrijedi je izraz koji je idiomatski u semantičkome smislu (usp. Burger 2015, 27).

Što je veće nesuglasje i nesrazmjer, time je idiomatičnost veća. Burger drži da je semantička idiomatičnost stupnjevito obilježje frazema.

Kao i u slučaju stabilnosti strukture i ovdje valja razlikovati različne perspektive promatranja, pri čemu je psiholingvističko i strukturno stajalište najvažnije.

Ako za neki frazem na razini jezičnoga sustava ne postoji odnos između slobodnoga i frazeološkoga značenja, ako se na temelju sintaktičkih i semantičkih pravila nekoga jezika izvodi slobodno značenje cijeloga izraza, a pri tome ne postoji semantičko pravilo koje dopušta 
da se iz slobodnoga značenja sastavnica i njihove sveze izvede frazeološko značenje, sa strukturno-semantičkoga stajališta posrijedi je izraz koji je dakle „idiomatski“ (usp. Burger 2015, 27).

Ako jedna sastavnica zadržava svoje slobodno značenje, posrijedi su djelomično idiomatski frazemi. Izrazi „koji su obilježeni nikakvim (ili minimalnim) semantičkim razlikama između frazeološkoga i doslovnoga značenja nazivaju se neidiomatskima“ (Burger 2015, 27).

Kao primjer potpuno idiomatskih frazema Burger $(2015,27)$ navodi frazeme (kojima dodajemo talijanske i hrvatske ekvivalente gdje postoje):

- u njemačkome: Öl ins Feuer gießen ili jemandem einen Korb geben

- u talijanskome: gettar olio sul fuoco

- u hrvatskome: dolijevati ulje na vatru i dati komu korpu.

Primjer djelomično idiomatskih frazema bio bi:

- u njemačkome: blinder Passagier

- u talijanskome: numero verde

- u hrvatskome: slijepi putnik.

Neidiomatski frazemi:

- u njemačkome: sich die Zähne putzen

- u talijanskome: lavarsi i denti

- u hrvatskome: prati zube. 


\subsection{Leksikaliziranost i reproduktivnost}

Prema Hrvatskoj enciklopediji leksikalizacija predstavlja „pretvaranje slobodnoga skupa riječi u vezani“. Leksikalizacija dolazi do izražaja „u specijalnome leksiku kada se skupovima riječi označuje jedan pojam“. 39

Prema Ruiz Gurillo (1997, § 5.2.1.2.) leksikalizacija je: „un fenómeno presente en los lexemas complejos que, debido a su uso frecuente, tienden a convertirse en unidades léxicas simples, con pérdida, por consiguiente, de su carácter sintagmático. Este proceso es tanto diacrónica como sincrónicamente un fenómeno gradual“.

Leksikalizacija u frazeologiji znači da prosječan govornik jednoga jezika određeni frazem „u većini slučajeva prepoznaje, a da u svim slučajevima i ne poznaje njegovo značenje i ne zna 'odakle on dolazi'، (Palm 1997, 36).

Pod pojmom reproduktivnosti frazema misli se da „već postoje kao fiksirani minitekstovi“ (Palm 1997, 36) što itekako pridonosi ekonomiji u jeziku jer se frazemi „u govoru i u tekstu ne moraju svaki put iznova tvoriti, već stoje na raspolaganju kao gotove jedinice“ (isto).

Važno je napomenuti da se frazem ne stvara u govornome procesu, nego se „kao već zapamćena, usvojena i naučena (ako se radi o stranome jeziku) cjelina uključuje u diskurs, pa se stoga može govoriti o njegovoj ustaljenosti odnosno reproduktivnosti“ (Fink-Arsovski 2002, $\S 1.2 .2$.$) .$

Kako pojašnjava Meisinger (1997, 65), premda je ,visok semantički naboj“ koji postiže svojom akutnošću, frazemom postaje ,tek činom općeg prihvaćanja formulacije unutar jezične i kulturne zajednice“ (isto).

U jeziku se manje ili više sve ,ponavlja, reproducira. Inače se ne bismo mogli sporazumjeti“ (Donalies 2009, 12). Glede frazema nije dakle riječ općenito o ,ponavljanju, nego poglavito o ponavljanju određenih sveza“ (isto).

Frazemi verbaliziraju jedan pojam. Kao i drugi leksemi imaju denominativnu funkciju i služe da se izvanjezično iskustvo strukturira tako što imenuju „denotate objektivne stvarnosti, oni su slike predmeta“ (Chrissou 2000, 35).

\footnotetext{
$39<$ http://www.enciklopedija.hr/natuknica.aspx?id=35935> (17.6.2019.).
} 
Idiomatičnost i stabilnost dovode do toga da se frazemi prepoznaju kao „oblikovane, gotove jedinice. Idiomatičnost kao cjelovitost značenja i stabilnost kao 'kognitivna pomoć pri pohranjivanju' razlikuju ih od slobodnih sveza i dovode do njihove leksikalizacije, pohrane u leksikonu“"(Chrissou 2005, 34).

Leksikalizacijom se provodi „monosemizacija i time određivanje frazeološkoga čitanja na razini sustava“ (Hallsteinsdóttir; Farø 2010, 134).

Unatoč različnosti, postoje mnoge sličnosti s leksemom, primjerice i frazem je „arbitrarna jedinica između označenoga i označitelja“ (Chrissou 2000, 35). Međutim, daju se prepoznati i određene razlike jer za razliku od leksema postoji ,asimetrija između razine izraza i sadržaja. Ta asimetrija temelji se na činjenici da cjelovitomu značenju usuprot stoji analitička struktura koja pak potječe od sekundarnoga karaktera frazeoloških znakova“ (isto).

Budući da su frazemi leksikalizirani kao verbalni znakovi, to dovodi kod svih frazema do toga da „frazeološko značenje ne odgovara zbroju značenjā pojedinih sastavnica jer se leksikalizacijom značenje sastavnica načelno sekundarizira, a značenje frazema kao znaka stupa na njihovo mjesto“ (Hallsteinsdóttir; Farø 2010, 133). Sve to dovodi do složenosti na razini sadržaja i stoga svi frazemi, a ne samo idiomi „mogu imati više čitanja, tj. barem jedno kompozicionalno i jedno frazeološko“" (isto). 


\section{BIBLIJA - KNJIGA KOJA JE DUBOKO PROŽELA TALIJANSKU I HRVATSKU KULTURU - NEPRESUŠAN IZVOR FRAZEMA}

Naziv Biblija potječe iz kasnolatinskoga Biblia, odnosno iz grčkoga $\tau \grave{\alpha} \beta \imath \beta \lambda i \alpha$ : 'knjižice, sveščići'. Počevši od trećega stoljeća tim su nazivom kršćanski autori kao Klement Aleksandrijski i Origen označavali svete knjige židova i kršćana. Kasnije se pojam latinizirao, postavši izvorom imenice ženskoga roda Biblija, koja ima značenje knjige par excellence (usp. Bibbia 1997, 9).

Sam naziv Biblija ne pojavljuje se u samoj Bibliji, u kojoj se nalaze izrazi kao sveta Pisma, stari i novi Savez ili Zavjet itd.

Kršćanima je sam Bog autor Biblije koji je govorio preko nadahnutih pisaca.

Nijedna knjiga nije prevedena na toliko svjetskih jezika i narječja kao Biblija. Prema mnogim izvorima, Biblija je danas najprodavanija knjiga na svijetu. Nesumnjivo je i najčitanija ili barem jedna od najčitanijih. Biblija je ujedno i prva tiskana knjiga uopće.

Jure Kaštelan u uvodnoj riječi prijevoda Biblije jasno ustvrđuje: „Biblija je najčitanija i najviše prevođena knjiga koju je dao stvaralački genij čovječanstva“(1987, V).

Biblija ili Sveto pismo za kršćane i židove spada u knjige koje su najviše obilježile svjetsku povijest. To je kod bez kojega je nemoguće razumjeti europsku kulturu i umjetnost. „Sveto pismo, Knjiga ili knjiga nad knjigama glavna je okosnica ukupne civilizacije čovječanstva“" (Petrač 185).

Bez poznavanja Staroga i Novoga zavjeta nemoguće je razumjeti korijene kulture i civilizacije te vrijednosti koje potječu iz biblijske slike čovjeka, ali ni svagdašnji život pojedinca i to „ne samo u smislu 'svete knjige' (Liber sacer) koju su vjernici Židovi i vjernici kršćani prihvatili i prihvaćaju kao živu Božju riječ, kao zbirku knjiga koje se smatraju svetima, nego i u smislu povijesnoga, kulturnoga i književnoga srcišta, stvarnoga duhovnoga rasta i razvitka čovjekova“" (Petrač, 185).

Biblija je „spomenik historije čovječanstva, jedna od najstarijih knjiga“ (Duda 1987, 1169). 
Od Milanskoga edikta 313. godine pa barem sve do prosvjetiteljstva Biblija je bila temeljem i vjerske i civilne kulture, života i zakonodavstva i stoga je Biblija „odigrala presudno važnu ulogu, i to na različite načine i na različitim razinama“ (Pranjković 2006, 23).

I ne samo za kršćane i židove nego i za „svakoga čovjeka Biblija je istovremeno zbirka povijesnih isprava i književno djelo izvorne i neprolazne umjetničke snage. Ona pripada zajedničkoj kulturi čovječanstva“" (Kaštelan 1987, V).

I Stari i Novi zavjet bili su trajnom inspiracijom umjetnicima od srednjega vijeka sve do danas: slikari, kipari, ali i duboresci i svi drugi umjetnici nadahnjivali su se biblijskim scenama i stvarali umjetnička dijela od značaja za svjetsku povijest umjetnosti.

Biblija se sastoji od Staroga i Novoga zavjeta. Prema katoličkoj tradiciji Stari se zavjet sastoji od 46 knjiga (39 protokanonskih i 7 deuterokanonskih): Petoknjižja (Postanak, Izlazak, Levitski zakonik, Brojevi i Ponovljeni zakon), Povijesnih knjiga (Jošua, Suci, Knjiga o Ruti, Prva knjiga o Samuelu, Druga knjiga o Samuelu, Prva knjiga o Kraljevima, Druga knjiga o Kraljevima, Prva knjiga ljetopisa, Druga knjiga ljetopisa, Knjiga Ezrina, Knjiga Nehemijina, Tobija, Judita, Estera, Prva knjiga o Makabejcima, Druga knjiga o Makabejcima), psalama, Mudrosnih knjiga (Job, Mudre izreke, Propovjednik, Pjesma nad pjesmama, Knjiga Mudrosti, Knjiga Sirahova) i Proročkih knjiga (tzv. četiri velika proroka: Izaija, Jeremija, Ezekiel i Daniel i dvanaest malih proroka: Hošea, Joel, Amos, Obadija, Jona, Mihej, Nahum, Habakuk, Sefanija, Hagaj, Zaharija i Malahija).

Novi zavjet sastoji se od 27 knjiga: četiriju evanđelja - Evanđelja po sv. Mateju, Luki, Marku i Ivanu, potom od Djela apostolskih, Poslanica sv. Pavla (Poslanica Rimljanima, 1. i 2. poslanica Korinćanima, Poslanica Galaćanima, Efežanima, Filipljanima, Kološanima, 1. i 2. poslanica Solunjanima, Poslanica Timoteju, Titu, Filemonu, Hebrejima) te od tzv. katoličkih poslanica (Jakovljeva poslanica, dvije poslanice apostola Petra, tri Ivanove poslanice, Judina poslanica) i od Otkrivenja ili Apokalipse.

Popis knjiga koje pripadaju tzv. kanonu razlikuje se u kršćana i židova, ali i među kršćanskim konfesijama, osobito između katolika i protestanata koji u 16. stoljeću stvaraju drukčiji kanon od katoličkoga i pravoslavnoga.

Židovi ne priznaju Novi zavjet, a pridržavaju se Staroga. Međutim, u početku nije postojao jedinstven kanon u svih židova. Samarijanci su imali samo Petoknjižje. Tek kasnije 
odlučeno je da u kanonu hebrejske Biblije bude 39 knjiga koje se svrstavaju u tri skupine: Petoknjižje, Proroci i Spisi ili Hagiografi. ${ }^{40}$

Prvi popis biblijskih knjiga koje pripadaju kanonu Katoličke crkve potječe s Pokrajinskoga sabora u Hiponu 393. godine. Taj kanon prihvatila je Latinska i Istočna crkva i potvrdio ga je Tridentski sabor 1546. godine (usp. Bibel 1991, 1).

Martin Luther u protestantski kanon uvrstio je samo tzv. protokanonske knjige (istovjetne s palestinskim kanonom), a izbacio tzv. deuterokanonske knjige. ${ }^{41}$ On ih je doduše preveo i preporučio njihovo čitanje, ali ih nije držao dijelom Svetoga pisma. Otad protestantske denominacije te knjige nazivaju apokrifima. Katolički teolozi apokrifima nazivaju druge knjige koje su se jedno vrijeme u mnogim kršćanskim i židovskim zajednicama držale dijelom Svetoga pisma i čitale tijekom bogoslužja, a koje ni Latinska ni Istočna crkva nije uvrstila u Sveto pismo (usp. Bibel 1991, 1 -2). Te spise protestanti nazivaju pseudoepigrafima.

Pravoslavni kanon, iako sličan katoličkomu, uglavnom se ravna prema Septuaginti, prijevodu Biblije na grčki jezik koji ima duži popis i „,apokrifne dijelove““. ${ }^{42}$

Cijela Biblija nastajala je postupno od 13. stoljeća prije Krista do prvoga stoljeća poslije Krista. Dugo vremena bila je ,jedinim živim svjedokom početka kulture i civilizacije čovječanstva“" (Petrač 185).

Stari zavjet nastajao je postupno. U početku je prenošen usmenom predajom, ${ }^{43}$ a potom je napisan na hebrejskome i djelomično na aramejskome jeziku (neka poglavlja Daniela i Ezre). Izvornik nekih knjiga izgubljen je i sačuvane su samo u grčkome prijevodu, kao primjerice Judita, Tobija, Baruh itd. (usp. Duda 1987, 1170). U vrijeme Isusa Krista hebrejski je bio kultni jezik židova, ne više govorni. Isus Krist i njegovi učenici govorili su aramejski. Često se aramejski nedovoljno precizno naziva narječjem hebrejskoga. Novi zavjet napisan je na grčkome jeziku koji je u prvome stoljeću poslije Krista bio svjetskim jezikom.

\footnotetext{
${ }^{40}$ Usp. $<$ http://www.enciklopedija.hr/natuknica.aspx?id=7453> (15.7.2015.).

${ }^{41}$ „Biblijske knjige Staroga zavjeta, koje je kršćanska tradicija dodala židovskome popisu 'božanskih pisama', tzv. palestinskomu kanonu. Popis knjiga utvrđen je 382. na crkvenome saboru u Rimu, a potvrđen 1546. na Tridentskome saboru. Deuterokanonske knjige su Tobija, Judita, Prva i Druga knjiga o Makabejcima, Knjiga Mudrosti, Knjiga Sirahova i Baruh“. <http://www.enciklopedija.hr/natuknica.aspx?id=14838> (8.8.2019.).

${ }^{42}$ Usp. $<$ http://www.enciklopedija.hr/natuknica.aspx?id=7453> (8.8.2019.).

${ }^{43}$ Stipe Botica $(1995,8)$ u skladu s time zaključuje da postoji mnogo dokaza da je biblijska usmena predaja optimalno uspješna.
} 
Premda mnogi misle da su posrijedi mrtvi jezici, svi biblijski jezici: i hebrejski i aramejski i grčki jezik i danas su u nekome obliku živi govorni jezici.

Prvi tekstovi na staroaramejskome potječu iz prvoga stoljeća prije Krista. Prije arapskih osvajanja to je bio najrašireniji jezik Bliskoga Istoka. Istočnoaramejski se još uvijek govori, ujedno je i kultni jezik sirijske kršćanske Crkve (jakobitske i nestorijanske). To je bio jezik kojime je govorio Isus Krist. Zapadnoaramejski je jezik u izumiranju (usp. Matasović 2002, $141-142){ }^{44}$

Hebrejski jezik predstavlja kaanansku skupinu sjeverozapadnosemitskih jezika. Hebrejski jezik jest jezik Biblije, jezik Staroga zavjeta. Izumro je u posljednjim stoljećima prije Krista, ali je ponovno oživljen u državi Izrael i naziva se danas ivrit (usp. Matasović 2002, 142).

Grčki jezik, i to novogrčki danas je književnim i govornim jezikom Grčke i grčkoga dijela Cipra. Za novogrčki jezik tipična je diglosija. Rabe se paralelno dva varijeteta: katarevusa i dimotiki. Katarevusa se rabi između ostaloga u crkvenim tekstovima i liturgiji i njezino razumijevanje nije potpuno moguće bez poznavanja starogrčkoga. ${ }^{45}$

Najstariji prijevodi klasične starine jesu Septuaginta ili Prijevod Sedamdesetorice, potom Vetus latina, najstarija latinska inačica Biblije i Vulgata, prijevod cijeloga katoličkog kanona biblijskih knjiga na latinski jezik.

Septuaginta nastaje od 3. - 2. stoljeća prije Krista. Posrijedi je prijevod Staroga zavjeta $\mathrm{s}$ hebrejskoga na grčki. Nije nastala $\mathrm{u}$ isto vrijeme i prijevod svakoga dijela Staroga zavjeta nije uspio na isti način (usp. Duda 1987, 1170).

Vetus latina ili Itala nastaje u 2. stoljeću poslije Krista i prethodi Vulgati, prijevodu sv. Jeronima. Prijevod je uglavnom doslovno prenošenje grčkoga teksta, što je uvjetovano tipično religioznom potrebom da se doslovno poštuje Božja riječ. Latinski jezik toga prijevoda jest jednostavan i pučki (usp. Renzi; Andreose 2003, 153).

Vulgata, prijevod sv. Jeronima Dalmatinca prijevod je, po nalogu pape Damaza, cijele Biblije na latinski jezik iz 383. godine poslije Krista. Jeronim uzima sve prijašnje inačice Biblije i uspoređuje ih s grčkim izvornikom. Iako je Jeronim „,bio profinjeni književnik, - u najvećemu

\footnotetext{
${ }^{44}$ Nažalost, ratovi i progoni kršćana, uspon ISIL-a posljednjih godina dodatno su negativno utjecali na opstanak aramejskoga. Budući da se trenutačno mnogi kršćani vraćaju na svoja ognjišta, teško je praviti procjene o broju govornika tih inače, manjinskih jezika.

${ }^{45}$ Usp. $<$ http://www.enciklopedija.hr/natuknica.aspx?id=23202> (15.7.2019.).
} 
dijelu zadržava pučki karakter“ (Renzi; Andreose 2003, 152). Od VII. stoljeća Vulgatu prihvaćaju sve kršćanske Crkve i postaje temeljem svetopisamskoga kanona.

Tridentski sabor proglašava izdanje Vulgate autentičnim. Godine 1546. počinje se raditi na ispravljenome izdanju i 1590. godine tiska se Nova Vulgata koja se naziva SikstoKlementina. $^{46}$

O utjecaju Biblije i biblijskoga jezika na Hrvate i hrvatski jezik prije dolaska u krajeve koje danas nastanjuju, može se samo nagađati. To je bilo vrijeme bespismenosti i o protohrvatskoj frazeologiji općenito se ništa pouzdano ne zna. Određeno djelovanje misionara i dodiri s kršćanskim narodima mogli su utjecati na prenošenje određenih riječi i frazema ili barem poslovica koji potječu iz Biblije.

Nakon nekoliko stoljeća dominacije kulture Avarskoga kaganata koja je bila ,poganska i bespismena“ (Katičić 2013, 34), počinje opismenjavanje slavenskih naroda „tek kad su prihvatili kršćanstvo“ (isto), a to je bilo između 8. i 10. stoljeća. Nakon obaranja Avarskoga kaganata širi se utjecaj franačke vlasti. Stoga „najraniji pisani jezik kojim se Hrvati predstavljaju svijetu jest latinski. Zato se i može reći da je latinski jezik materinski jezik hrvatske književnosti“" (Katičić 2013, 35).

Hrvati najprije čitaju i pišu samo na latinskome. Latinski je tada u Crkvi bio jedini dopušteni jezik na kojemu su se služili misa i druga bogoslužja. Međutim, to ne znači da je bilo zabranjeno moliti se i na materinskome jeziku jer ,sinoda u Frankfurtu 794. vrlo jasno određuje (Capitularia Nr. 28, 52): 'Nitko neka ne vjeruje da se samo na tri jezika smije moliti Bogu, jer se Bogu mole na svim jezicima i čovjek bude uslišan ako zatraži što je pravedno'“ (Katičić 2013, 38).

Tada počinje i poraba „dušobrižničke književnosti na slavenskom jeziku novopokrštenih Hrvata“ (Katičić 2013, 39), a uz različite pučke pobožnosti, propovijedi takva književnost mogla je obuhvaćati i ,zbirku prijevoda blagdanskih čitanja iz poslanica i evanđelja“ (isto).

To je svakako važno jer time počinje izravni dodir Hrvata sa svetopisamskim tekstovima na svome materinskom jeziku, a time veliki utjecaj Biblije i biblijskoga stila ne samo na književnost, nego i na govorni jezik i osobito na njegovu frazeologiju i paremiologiju.

\footnotetext{
${ }^{46}$ Usp. $<$ http://www.enciklopedija.hr/natuknica.aspx?ID=65680> (19.7.2019.).
} 
Od prihvaćanja kršćanstva hrvatska je tradicijska kultura „prihvatila biblijsku duhovnu nadgradnju kao svoje bitno i prepoznatljivo obilježje. To je razlog da su se biblijske stilizacije lako uskladile s potrebama hrvatskoga sudionika u govornom priopćaju. Tom je korisniku odgovarao i visok stil biblijskoga govora i znatan patos takvog govora“ (Botica 1995, 22).

Biblija je danas prevedena na 1850 jezika (usp. Földes 1990). Za svaki narod prvotisak Biblije ima osobitu važnost. Hrvati su dobili prvi cjeloviti prijevod Biblije 1838. godine, a prevoditelj je bio franjevac Matija Petar Katančić (usp. Petrač 1994, 185).

Katančićev potpuni prijevod Biblije ujedno je od velike važnosti za novi hrvatski standard jer je „konačan dokaz da je novi standard u stanju suočiti se sa svim zadacima“ (Katičić 1992, 88).

Međutim, Katančić nije prvi koji prevodi Bibliju jer „prije biblijskoga prvotiska iz 1831. godine treba istaknuti šest rukopisnih pokušaja prijevoda Biblije“ (Petrač 1994, 186).

Prijevodi Biblije na pojedine jezike predstavljaju najčešće vrhunska književna djela, što ima osobit utjecaj na razvoj samoga jezika, njegove književnosti, ali također i frazeologije i paremiologije. Stoga je u mnogim od tih jezika ,povelik dio leksičkoga fonda dobio posebne biblijske konotacije i posebne simboličke vrijednosti“ (Pranjković 2006, 23).

Utjecaj latinskoga jezika i Biblije na talijansku književnost također je nemjerljiv. Budući da je latinski jezik nastao na području Italije, u drevnome Laciju, Italija je upravo najkasnije razvija pučki jezik koji se razlikuje od latinskoga. Dok u drugim europskim zemljama, kao u Francuskoj i Španjolskoj, prvi pisani spomenici koji svjedoče o postojanju pučkoga, romanskoga jezika potječu iz 8. stoljeća, ,u Italiji gdje je latinski imao starije i dakle dublje korijenje prvi pisani spomenik na pučkome jeziku potječe s kraja 10. stoljeća“" (Sensini $1997,586)$.

Propovijedanje na pučkome jeziku u romanskim zemljama počinje već u 9. stoljeću. Biskupi koji su se okupili 813. godine u Toursu ustvrdili su da puk ne razumije propovijedi na latinskome i da se u propovijedima treba rabiti „rustica romana lingua“ ('pučki romanski jezik') (usp. Renzi; Andreose 2003, 203).

Premda je u 16. i 17. stoljeću bilo nekoliko pokušaja prevođenja Biblije na talijanski, ti prijevodi uglavnom se nisu proširili: neke je osudila Inkvizicija, a neki prijevodi, kao primjerice protestantski prijevod, tiskani su u inozemstvu i potajno su se širili u vrlo ograničenome opsegu. 
Prvi cjeloviti prijevod Biblije, Vulgate na talijanskome tiskan je 1773. godine u Mletcima La Sacra Bibbia volgarizzata da Niccolò Malermi koju je pregledao Alvise Guerra. ${ }^{47}$

Dakle, Vulgata Jeronima Dalmatinca može se svakako držati temeljnim izvorom frazema biblijskoga podrijetla i poslovica u standardnome talijanskom jeziku. ${ }^{48}$

Međutim, odnos prema latinskome jeziku u liturgiji u Italiji bio je drukčiji nego u slavenskim i germanskim zemljama. Upravo se za najniže i nepismene slojeve društva crkva sa svojim usmenim i figuralnim porukama stoljećima nametnula kao ,,'l'istituto della parola', il luogo incipale dove si trasmettevano e custodivano i significati di ogni discorso sul mondo“ (Beccaria 1999, 8). Crkveni je jezik duboko prožeo jezik običnoga čovjeka: „esclamazioni, intercalari, proverbi, massime, inconsuete metafore ... parole latine, innanzitutto, adottate nella parlata di coloro che il latino non sapevano: parole perciò incomprese, immediatamente corrotte, sviate o adoperate consapevolmente in compiaciuto intento scherzoso, parodico, antifrastico“ (isto).

Nerazumijevanje latinskoga ili riječi i izrazi koje je puk krivo razumio bili su izvorom čak i mnogih frazema i poslovica i to ne samo u standardnome jeziku, nego u mnoštvu talijanskih dijalekata. Nestajanjem dijalekata i dokinućem latinske liturgije u šezdesetim godinama 20. stoljeća polako su nestajali i mnogi izrazi i frazemi koji su „stoljećima pratili razgovore naših roditelja, obojivši najslobodniji i najneformalniji registar njihova govornoga jezika“ (Beccaria 1999, 9).

Neki od tih frazema ipak i danas postoje u frazeološkome inventaru talijanskoga jezika.

Dakle, unatoč istomu izvoru, Vulgati sv. Jeronima odnos prema latinskim tekstovima bio je drukčiji u hrvatskome i talijanskome jeziku. Dok je za više registre zacijelo mjerodavniji izvorni biblijski tekst - u latinskome prijevodu ili u prijevodu na pučke jezike, za narječja i običnoga čovjeka latinski izvornik, pa čak i kad su ga krivo razumjeli, igrao je u Italiji puno veću ulogu nego u Hrvata.

\footnotetext{
47 Usp. $<$ http://www.treccani.it/enciclopedia/bibbie-d-italia-la-traduzione-dei-testi-biblici-in-italiano-tra-otto-enovecento_\%28Cristiani-d\%27Italia\%29/> (7.8.2019.).

48 Mellado Blanco (2017, 59) u supostavnoj raščlambi frazema biblijskoga podrijetla u njemačkome i španjolskome naglašava važnost Vulgate kao jedine prihvaćene verzije Biblije u katoličkim zemljama: „Por otra parte, conviene recordar que a partir de Lutero (1545), la lengua de la Biblia fue el alemán, a diferencia de los países contrarreformistas en los que el latín dominaba todo el ámbito eclesiástico. En estos países, la única versión aceptada de la Biblia fue la Vulgata desde el Concilio de Trento (1545-1563) hasta el Concilio Vaticano II (1965)“.
} 
No i sam jezik Biblije bio je pogodan za višestruke utjecaje i na književni jezik, ali i na narječja i svagdašnji govor običnoga čovjeka. Kao i cijela književnost drevnoga Orijenta, Biblija je obilježena ,hijazmom, anaforom, klimaksom, hiperbolom, personifikacijom i parabolom“ (Földes 1990, 57). Jedna od posebnosti hebrejske poezije jest „dvostruko ili trostruko ponavljanje iste misli različitim riječima. To se temelji u koncentričnome razvoju jedne misli, što je tipično za semitsko razmišljanje i poglavito u dinamičnome osjećajnom životu ovih naroda čija se emocionalna struktura valovito razvija“ (isto).

Sve te različite posebnosti te bogati biblijski slikoviti jezik bitno su pridonijeli „stvaranju brojnih poslovica, frazeoloških izričaja i drugih čvrstih sintagmi“ (Földes 1990, 57). Stoga se s pravom može reći da je Biblija bitno obilježila frazeološko i paremiološko blago mnogih jezika i ,biblijske je provenijencije i cijelo mnoštvo ustaljenih izraza $\mathrm{i} / \mathrm{ili}$ frazema i u starijim biblijskim ili s Biblijom na bilo koji način izravnije povezanim tekstovima, a i u suvremenom jeziku“ (Pranjković 2006, 29). To bogatstvo jezičnih slika i metaforičnih izraza preko prijevoda Biblije na brojne jezike svijeta ,ušlo je u bezbrojne jezične zajednice i time u aktivnu jezičnu uporabu milijuna ljudi mnogih kultura“ (Földes 1990, 57).

Osim toga, različiti prijevodi i različiti ekvivalenti u pojedinim jezicima također su pridonijeli stvaranju pojedinih frazema koji nemaju ekvivalente u drugim jezicima.

Unatoč tomu što su postojali i drugi utjecaji na frazeologiju europskih jezika ipak se može konstatirati da je ,cijelo mnoštvo frazema i u hrvatskom i u drugim (posebno europskim) jezicima očite biblijske (odnosno, u širem smislu, judeo-kršćanske) provenijencije“ (Pranjković 2006, 29).

Stoga je biblijski stil ,i u svome izvorniku (hebrejski, grčki) i preveden na žive narodne jezike [...] uvijek prepoznatljiv kao stil modo biblico. Ovo prvotno vlasništvo židovskoga naroda (svi su zadnji oblikovatelji / redaktori biblijskih tekstova bili Židovi) lako prijanja na žive govore bilo kojega naroda (čini se prvenstveno zbog prirodne logike i prirodne dosljednosti onoga što se govori)““(Botica 1995, 21).

K tome, Riccardo Picchio (1991) hrvatski jezik uključuje u tzv. „Slavia Latina“ ili „Slavia Romana“, slavenske zemlje koje su bile pod utjecajem Rimske crkve i latinskogermanskoga svijeta za razliku od „Slavia Ortodoxa“, slavenskih pravoslavnih naroda koji su bili pod utjecajem grčko-bizantskoga svijeta. U 9. stoljeću ćirilometodska misija odražavala je „proširenu svijest o relativno kompaktnoj slavenskoj etnolingvističkoj zajednici da su misionari 
koji su dolazili s egejske obale mogli propovijedati u srednjoj Europi, ali i težnju ondašnjih supersila ,'rimskoga svijeta' (uglavnom latinsko-germanskoga) i 'bizantskoga' (grčkogavišenacionalnoga) da Slavenima nametnu već dva različita kulturna modela“ (Picchio 1991, 14). Tako je ,podjela slavenskoga svijeta na dvoje, u različite zone utjecaja, sve više različne i čak međusobno suprotstavljene, postala trajnom činjenicom novoga tisućljeća““ (isto).

Sve do nastanka modernih nacija književnosti slavenskih naroda uvjetovane su „shemama dviju kršćanskih civilizacija koje su uključile slavenske zemlje u svoje crkvene jurisdikcije“(Picchio 1991, 14).

I Katičić napominje da u devetome stoljeću ,pismenost dolazi i hrvatskome vladanju i među sav puk slavenskoga jezika u Dalmaciji. Ta je pismenost dvojaka, latinska i slavenska. Latinska pismenost i književna naobrazba dolazi iz područja franačke crkve, a slavenska iz prostora na kojem su braća Konstantin i Metodije razvili svoje učiteljstvo“" (Katičić 1999, 22).

To nam jasno pokazuje veliki utjecaj latinskoga jezika i kulture, ali i germanskoga svijeta na hrvatski jezik, književnost, kulturu te posebice frazeologiju i paremiologiju. Katičić govoreći o početcima pismenosti i književnosti u Hrvata napominje: „Ta pismenost je isprva nerazdvojno vezana s jezikom, pa se tako kneževska Hrvatska sebi i svijetu u prvo vrijeme javno predstavlja samo latinski. Odatle se nešto preoštreno može kazati da je latinski materinski jezik hrvatske književnosti, a to će reći najprije pismenosti. Odatle se dojmljivo razabire koliko je latinski jezik važan u povijesti hrvatskoga, kako njega takav kakav jest bez latinskoga i nema. Kad pišemo hrvatski, u nekom smislu pišemo i latinski““ $(1999,37)$. 


\subsection{Karakteristike frazema biblijskoga podrijetla}

Frazemi biblijskoga podrijetla (neki ih nazivaju biblizmima ili biblijskim frazemima) jesu ,jezični izrazi ustaljene strukture preuzeti iz prijevoda Biblije ili motivirani biblijskim prispodobama, parabolama, događajima ili simbolima“"(Vidović Bolt; Ribarova 2005, 644).

Prisutni su u standardnome jeziku, i to u manjoj ili većoj mjeri u svim europskim jezicima te u većini svjetskih jezika (Biblija je prevedena na 1850 jezika $^{49}$ ). Posrijedi su različiti tipovi frazema. Navedimo samo neke, primjerice:

a) Poredbeni frazemi:

- u talijanskome: vecchio come Matusalemme

- u hrvatskome: star kao Metuzalem

- u njemačkome: alt wie Methusalem

- u francuskome: vieux comme Mathusalem

- u španjolskome: viejo como Matusalén itd.

b) Leksički binomi:

- u talijanskome: l'alfa e l'omega

- u hrvatskome: alfa i omega

- u njemačkome: das Alpha und das Omega

- u francuskome: l'alpha et l'oméga

- u španjolskome: alfa y omega itd.

\footnotetext{
${ }^{49}$ Moguće je svakako da se frazemi biblijskoga podrijetla kalkiranjem usmeno prenose i u druge jezike koji su još $\mathrm{u}$ fazi bespismenosti, a u druge jezike koji imaju pismo mogu se prenositi prevođenjem poznatih knjiženih djela iz svjetskih jezika.
} 
Leksički binomi s vlastitim imenima:

- u talijanskome: fare da Marta e da Maddalena, mandare qualcuno da Erode a Pilato

- u hrvatskome: od Adama i Eve, od Poncija do Pilata

- u njemačkome: bei Adam und Eva anfangen, Krethi und Plethi

- u francuskome: Pierre et Paul

- u španjolskome: David y Goliat itd.

c) Mnoge rutinske formule preuzete su iz Biblije ili su inspirirane biblijskim tekstovima:

- u talijanskome: grazie a Dio

- u hrvatskome: Bogu hvala

- u njemačkome: Gott sei Dank

- u francuskome: Dieu merci

- u španjolskome: gracias a Dios itd.

d) Mnoge izreke i poslovice biblijskoga su podrijetla, primjerice:

- u talijanskome: Occhio per occhio, dente per dente

- u hrvatskome: Oko za oko, zub za zub

- u njemačkome: Auge um Auge, Zahn um Zahn

- u francuskome: Oeil pour oeil, dent pour dent

- u španjolskome: Ojo por ojo, diente por diente itd.

U regionalnim i dijalektalnim varijetetima katkad pojavljuju se i puno izraženije. 
Neki se biblijski frazemi rabe dosta dugo. Drugi zastarijevaju i nestaju, a drugi opet nastaju ili doživljavaju različite modifikacije i promjene. Neki se ne rabe u govoru i ,samo su rječnički potvrđeni“ (Opašić 2013, 366).

Frazeme biblijskoga podrijetla istraživali su filolozi, folkloristi, teolozi, ali i jezikoslovci, frazeolozi i paremiolozi i oni spadaju u „najbolje opisanu skupinu frazema uopće“ (Piirainen 2012a, 171).

Biblija je duga stoljeća bila često jedina knjiga koja se čitala, osobito nakon izuma tiska i jedina knjiga koju su mnoge obitelji posjedovale. Mnogi tekstovi učili su se naizust (usp. Piirainen 2012a, 171).

Za europske jezike Biblija predstavlja „najsnažniji izvor različitih leksičkih jedinica kao što su frazemi, kolokacijske veze, poslovice, krilatice i sl.“(Opašić 2013, 64).

I stoljećima prije izuma tiska dok je većina ljudi bila nepismena vjernici su bili u izravnome dodiru s biblijskim tekstovima. Biblijski tekstovi, posebice novozavjetni, svake su nedjelje i na velike blagdane čitani (u hrvatskome narodu pjevani) tijekom liturgije i drugih obreda.

Riječ je o određenim perikopama iz Evanđelja te odlomcima poslanica koji su se čitali ili pjevali pred pukom i koji su uglavnom bili temom propovijedi.

Osim toga, u podjeli sakramenata, pučkim pobožnostima, pasionskoj baštini, crkvenim pjesmama na narodnome jeziku također su se doslovno prenosili biblijski izrazi i frazemi i ti su se tekstovi često znali naizust.

Međutim, budući da su biblijski prijevodi uglavnom djela iznimne kakvoće sa snažnom poetskom snagom, frazemi biblijskoga podrijetla, premda imaju isti izvor, imaju različite oblike u različitim jezicima. Osim toga, recepcija biblijskih citata „nije se odvijala na jedinstven način u različitim jezičnim zajednicama. To znači, biblijske su se izreke u pojedinim jezicima različno tumačile, tijekom vremena dobivale su često drugo, novo (ili dodatno) značenje, njihovo stilističko djelovanje kao i pragmatičke potencije mijenjale su se kadšto na različit način u različitim jezicima“" (Földes 1990, 60).

Istraživanja pokazuju da se neki frazemi za koje se čini da potječu iz Biblije pojavljuju već i ranije i ne pojavljuju se prvi put u biblijskim prijevodima. Mnogi frazemi postojali su i prije pojavljivanja u hebrejskome i grčkome originalu Biblije i prenosili su se usmeno ili 
pismeno. Njihov prijevod na latinski i na narodne jezike učinio ih je zajedničkim europskim frazemima ili čak i internacionalizmima (usp. Földes 1990, 60).

Iznimno velik utjecaj Biblije osjeća se poglavito u paremiologiji, u poslovicama, mudrim izrekama, aforizmima itd.

Utjecaj Biblije zamjetan je i u somatizmima te u frazemima sa zoonimskom sastavnicom (usp. Vidović Bolt 2011; Jelaska 2014).

Biblija je u katoličanstvu, pravoslavlju i u protestantizmu odigrala veliki utjecaj na život običnih ljudi, ali i na umjetnost, književnost i jezik. Važno je napomenuti da unatoč brojnim podudarnostima o važnosti Svetoga pisma u katoličanstvu, pravoslavlju i protestantizmu ipak postoje brojne različnosti na koje valja upozoriti.

U protestantizmu Biblija je stoljećima bila jedina knjiga koja se čitala, ,jedina knjiga u mnogim njemačkim obiteljima“ (Piirainen 2012a, 171). Protestanti se odvajaju od Katoličke Crkve u 16. stoljeću. Odbacuju autoritet Rimskoga pape i biskupa kao i crkvenih otaca i naučitelja. Odbacuju bilo kakva tumačenja Svetoga pisma i zalažu se da svaki vjernik slobodno mora čitati Sveto pismo. Stoga se zalažu za prijevod cijele Biblije na narodne jezike i potiču vjernike da čitaju cijelu Bibliju. O tome Katičić $(2015,87)$ piše: „Protestanti su osobitu pomnju posvećivali Bibliji jer su učili da je Sveto pismo, a ne tradicija i nauk Rimske crkve, jedini izvor prave kršćanske istine. Bibliju je stoga trebalo prevesti na jezike svih naroda kojima se propovijedala kršćanska vjera. Bez prijevoda Biblije na jezik razumljiv svima kojima su se obraćali protestantski vjerovjesnici nije moglo biti širenja nove vjeroispovijesti““.

To dovodi do toga da biblijski stil itekako utječe na književni i govorni jezik protestantskih naroda. O tome svjedoče i danas brojni frazemi biblijskoga podrijetla u jezicima protestantskih naroda.

Međutim, Biblija je imala „veliki utjecaj i na ruski jezik“ (Piirainen 2012a, 171). Isto se može reći i za druge pravoslavne narode. Utjecaj crkvenoslavenskoga, „liturgijskoga jezika Ruske pravoslavne crkve igrao je važnu ulogu u nastavi i obrazovanju“ (Piirainen 2012a, 171). Isto se može tvrditi i za ostale slavenske narode: Makedonce, Bugare, Srbe, Crnogorce, Ukrajince i Bjeloruse. Riccardo Picchio $(1991,22)$ govoreći od velikoj povezanosti Rusa, Ukrajinaca, Bjelorusa, Srba, Bugara i na koncu Makedonaca, njihovih jezika i književnosti, naglašava da se može ,govoriti o jednome jedinstvenom sustavu književnosti pravoslavnoga 
slavenstva („Slavia Ortodoxa“) jer je stoljećima postojao trajni međuodnos i između sastavnica zajedničke književne konvencije kao i između ovih sastavnica i sociokulturnoga okružja“.

Premda Katolička crkva dugo vremena nije dopuštala prijevod cijele Biblije, katolički su narodi bili stalno u izravnome dodiru s biblijskim jezicima. Nedjeljna i blagdanska čitanja, podjela sakramenata, molitve, pjesme i vjerska pouka sadržavali su bezbrojne biblijske izraze.

Lekcionari i obrednici poznati još u srednjemu vijeku odigrali su važnu ulogu u razvoju hrvatskoga književnog jezika. Katičić $(2015,58)$ primjećuje: „Tako je u razdoblju od kraja 15. do 17. stoljeća stvorena široka podloga za razvoj hrvatskoga književnog jezika, za njegov izlazak iz srednjovjekovlja. Doveden je tako na prag novoga doba. Nije to dakako proizveo samo lekcionar s čitanjima poslanice i evanđelja za mise tijekom crkvene godine i na dane pojedinih svetaca. Tu je i ritual, tekstovi za razne obrede, zatim pobožnosti i formule za ispitivanje savjesti i ispovijed, te crkvene pjesme kojima je puk iskazivao svoju pobožnost".

Uz frazeme biblijskoga podrijetla valja spomenuti i tzv. „kristijanizme“, 50 frazeme koji potječu iz liturgije i ostalih bogoslužnih čina, raznih životopisa svetaca, života Crkve, svećenstva i redovništva i monaštva, blagdanskih običaja itd. Postoji velik broj frazema toga tipa i u talijanskome i u hrvatskome i to ne samo u standardnome talijanskom i hrvatskom jeziku, nego i u regionalnim varijetetima i dijalektima.

Zbog djelomične razumljivosti latinske liturgije u talijanskome je postojao drukčiji odnos prema liturgiji nego u slavenskim i germanskim zemljama. Upravo je djelomična razumljivost ili nerazumljivost određenih dijelova u liturgiji bila vrelom frazema.

Budući da su Talijani i Hrvati većim dijelom (rimo)katolici i da su se stoljećima uglavnom služili katoličkim prijevodima najprije dijelova Svetoga pisma, a kasnije i cijeloga Svetoga pisma, s velikom vjerojatnošću može se pretpostaviti da frazemi prisutni u obama jezicima potječu pretežito iz tih izvora.

Već smo spomenuli da je narav frazema vagabundska. Stoga se može pretpostaviti utjecaj prijevoda i kalkova s jezikā pravoslavnih naroda preko književnosti, umjetnosti i filma, a u hrvatskome i mogući utjecaj istočne ćirilometodske tradicije bilo preko obližnjih pravoslavnih naroda bilo preko grkokatoličke zajednice, prisutne u hrvatskome katolištvu već dugi niz stoljeća i njihova osobitoga truda oko čuvanja i promicanja hrvatskoga jezika.

\footnotetext{
50 Turk $(1994,40)$ ih naziva „frazemima uopće kršćanskoga karaktera“.
} 
Osobita važnost posvećuje se pak dodirima s njemačkim i talijanskim jezikom i njihovom frazeologijom. Turk $(1994,42)$ pretpostavlja da se „,s obzirom na kulturne i jezične dodire u hrvatskome jeziku mogu očekivati utjecaji njemačkog i talijanskog jezika“. Premda se ne isključuje ni mogućnost autohtone tvorbe mora se uzeti u obzir da je ,neki drugi jezik davalac, a pretpostavljeni jezik davalac može izvršiti samo posredničku ulogu“ (isto, 43). Stoga zaključuje da su ,njemački i talijanski jezik mogli s obzirom na kulturne dodire biti jezici na temelju kojih se kalkiralo na leksičkoj razini, pa onda i u frazeologiji, a mogli su odigrati i ulogu posredničkih jezika“" (isto).

\subsection{Biblizmi kao internacionalizmi}

Pojam internacionalizam od latinskoga inter: 'među, između' + lat. natio: 'narod' uz svoje značenje u politici ima široku primjenu i u jezikoslovlju. Pod internacionalizmom podrazumijevamo uglavnom leksem koji u više jezika ima manje ili više jedinstveno značenje i podrijetlo. Internacionalizmi u europskim jezicima uglavnom su latinizmi ili grecizmi, kasnije i galicizmi i anglicizmi te pojmovi iz nekih drugih izvora, primjerice egzotičnih jezika, koji su uglavnom kalkiranjem prenošeni iz jezika u jezik.

Internacionalizmi se u različitim jezicima uglavnom slično pišu i izgovaraju ${ }^{51}$ pa su time općenito razumljivi kao primjerice tal. l'azione, hrv. akcija, njem. die Aktion ili tal. l'altare, hrv. oltar, njem. der Altar itd.

I u frazeologiji od samih se početaka zamjećivalo postojanje mnogih zajedničkih frazema u mnogim europskim, ali i svjetskim jezicima: posrijedi su frazemi koji uglavnom potječu iz latinskoga i starogrčkoga, tj. grčke i rimske mitologije, književnosti i kulture, rimskoga prava ili iz Biblije.

Frazeološki su internacionalizmi prema Fink-Arsovski $(2016,80)$,frazemi koji se u jednakom ili vrlo sličnom obliku upotrebljavaju u mnogim europskim jezicima pri čemu imaju i jednako ili vrlo blisko značenje“. Ujedno napominje da u europskim jezicima postoje frazemi koji su ne samo strukturni, slikovni i semantički ekvivalenti „već su im zajednički porijeklo, izvor i motivacija. Kao primjer se u prvom redu može spomenuti Biblija koja je europskim

\footnotetext{
${ }^{51}$ Svaki jezik ima svoje fonološke značajke koje utječu na izgovor internacionalizama. Kojiput na to utječu i pravopisna pravila. Uglavnom dolazi do prilagodbe nastavaka, katkad s promjenom roda i sl.
} 
jezicima podarila velik broj frazema (npr. dolina suza, oprati / prati ruke <kao Pilat $>$, riječju i djelom)“(isto).

Frazemi biblijskoga podrijetla mogu se dakle uključiti u internacionalizme, oni u biti i jesu prototipom internacionalizama, i to onoga tipa koji je povezan s jednim kulturnim krugom ili civilizacijom tako da su jako prošireni internacionalizmi ponajprije u zapadnome kulturnom krugu čiji su korijeni judeo-kršćanski. Tomu krugu pripadaju i talijanski i hrvatski jezik čiji će biblijski frazemi biti predmetom raščlambe u drugome dijelu ovoga rada.

S obzirom na frazeme biblijskoga podrijetla i na njihovu veliku proširenost $u$ europskim jezicima, uglavnom kao frazeme iz viših registara, mora se dodati da ,potječu manje od usmenih jezičnih kontakata, već poglavito od zajedničkoga kodeksa izobrazbe obrazovanoga europskog sloja“ (Piirainen 2006, 204). Njihovo je kalkiranje osobito podupirala ,intenzivna razmjena mišljenja kroz mnoge europske jezike koja se mogla odvijati samo preko čitanja i pisanja, poglavito preko latinskoga kao univerzalnoga jezika“ (isto).

Kao što je spomenuto, frazemi biblijskoga podrijetla spadaju u skupinu internacionalizama, frazema koji potječu uglavnom iz istoga izvora Biblije ili Svetoga pisma, i to konkretno u talijanskome i hrvatskome iz stoljećima najproširenijega prijevoda Biblije na latinski, odnosno stoljećima jedinoga koji je Katolička crkva prihvaćala, Vulgate Jeronima Dalmatinca.

Premda je Biblija napisana na hebrejskome, aramejskome i grčkome, u Europi je tijekom dugih stoljeća bila dostupna samo na latinskome jeziku. Inače ,tijekom cijeloga srednjeg vijeka na europskome Zapadu, ne samo romanskome, pisalo se latinski“ (Renzi; Andreose 2003, 153).

Klasični su jezici „osobito latinski, imali vrlo važnu ulogu za cjelokupnu hrvatsku kulturnu i znanstvenu tradiciju i s tim u vezi i za hrvatski jezik. Latinski je bio jezik književnosti, vrlo dugo jezik državne administracije, školstva i znanosti, te jezik katoličkoga bogoslužja“ (Turk 2013, 137). Turk također napominje, što je za frazeme biblijskoga podrijetla osobito važno da je latinski ,imao i ulogu jezika posrednika između grčkoga i hrvatskoga jezika“ (isto). 
K tome možemo pridodati da je osobito Vulgata, cjeloviti prijevod Biblije imala ulogu i posrednika i između klasičnoga hebrejskog i aramejskoga te talijanskoga i hrvatskoga jezika. ${ }^{52}$

Frazeme biblijskoga podrijetla može se svrstati i u „frazeme široke proširenosti (widespread idioms)“ (Piirainen 2012a, 171) ili, stavljajući u prvi plan arealni pristup frazemima, „frazeme proširene u više europskih jezika ili frazeme proširene na više kontinenata“(Piirainen 2008). Naziva ih se i „kulturnim europeizmima“(Corpas Pastor 2003), a s tim u svezi rabi se i pojam, ,interfrazema“. Turk (1994) frazeme biblijskoga podrijetla i uopće kršćanskoga karaktera svrstava u „općeeuropske frazeme“.

Brojni su, premda s velikim razlikama u kvantiteti, u svim europskim jezicima (usp. Földes 1990; Luque Nadal 2010; Mellado Blanco 2017).

Mellado Blanco drži da je pojam internacionalizam povezan s metodičkim problemima „pues los paralelismos interlingüísticos en la forma y significado de los fraseologismos no tienen que deberse necesariamente al hecho de ser internacionalismos (procedentes de una única fuente), pudiendo tratarse igualmente de calcos entre lenguas o de formas autóctonas de génesis paralela en varias lenguas“، $(2017,53)$.

Turk (2013, 270 - 271) napominje da europski frazemi u koje uvrštava i frazeme biblijskoga podrijetla ,imaju zajedničko ishodište. Isto značenje i podudaran ili tek neznatno izmijenjen leksemski sastav. U većini je primjera poznato njihovo ishodište, ali ne i putovi širenja. Osim općeeuropskih postoje i frazemi čija podudarnost upućuje na to da su vjerojatno kalkirani“.

Mellado Blando $(2017,54)$ internacionalizme dijeli na „prirodne“ koji su uvjetovani „kognitivnim mehanizmima koji su zajednički jezicima“ kao primjerice somatizmi.

Nemali broj frazema biblijskoga podrijetla upravo pripada skupini somatizama ili pseudokinegrama (usp. Mellado Blanco 2000).

\footnotetext{
${ }^{52}$ Prvi prijevod grčke Biblije na latinski Vetus Latina ili Itala bio je doslovno prenošenje grčkoga teksta na latinski zbog strahopoštovanja prema Božjoj riječi (usp. Renzi; Andreose 2003, 153). Već taj prijevod unosi mnoštvo grčkih kalkova u latinski jezik, što je inače odlika latinskoga jezika kršćanskih pisaca.
} 
Osim ,prirodnih“ postoje i tzv. „kulturni“ internacionalizmi koji su slični u mnogim jezicima jer su prevedeni iz istoga izvora ili su posuđeni iz drugoga jezika (usp. Mellado Blanco 2017, 54).

S time u svezi i Schindler (2005) razlikuje frazeološke kalkove i internacionalizme pri čemu je važno naglasiti da ovi posljednji potječu iz zajedničkoga izvora. Glede frazeoloških kalkova, on ih definira kao frazeme ,čije se podrijetlo ne može utvrditi za jedan jezik. Njihovo preuzimanje odvija se usmenim ili pismenim jezičnim dodirima koji se pojedinačno više ne mogu dokazati““(isto).

Broj frazema preuzetih kalkiranjem dosta je velik, a „opće pretpostavke za kalkiranje su: semantička podudarnost u jeziku primaocu i pretpostavljenom jeziku davaocu, potpuna ili bar velika podudarnost u izrazu obaju jezika, kulturno-povijesne mogućnosti preuzimanja, zatim jezik davalac ali i jezik posrednik“ (Turk 1994, 29).

Međutim, Turk $(2013,271)$ napominje da je ,pri utvrđivanju je li neki frazem kalkiran i kojeg je podrijetla njegov uzor potreban veliki oprez“.

To potvrđuju i suvremena istraživanja koja pokazuju da i među mnogim frazemima biblijskoga podrijetla ne postoji međujezična ekvivalencija. Luque Nadal, analizirajući frazeme biblijskoga podrijetla u španjolskome i engleskome, dakle frazeme koji potječu iz istoga izvora, dolazi do spoznaje da unatoč istomu izvoru i istoj formalnoj strukturi i surječju u kojemu se spomenuti frazemi rabe „distan mucho de ser equivalentes“ $(2010,269)$.

Mellado Blanco $(2017,56)$ navodi sljedeće razloge koji do toga dovode:

1) Biblija se na sličan način prevodila na različite jezike i prevoditelji su određene izraze nastojali prilagoditi duhu jezika. Prijevod pojedinih izraza uvjetovan je različitim antropološkim, zemljopisnim, zoološkim, botaničkim itd. karakteristikama pojedine jezične zajednice.

2) Isti biblijski izraz pojavljuje se u lagano izmijenjenom obliku u različitim odlomcima knjiga od kojih se sastoji Biblija. Posljedica toga jesu formalne različnosti u jezicima primateljima koje se uvijek ne nadahnjuju istim biblijskim tekstom.

3) Međujezične razlike frazema biblijskoga podrijetla mogu biti uvjetovane semantičkim razvojem određenih leksičkih sastavnica frazema u svakome jeziku kao i razlikama u uporabi u konkretnim komunikativnim situacijama. 
K tome, valja spomenuti da različiti jezici „mogu razviti različita značenja za isti frazem biblijskoga podrijetla“" (Mellado Blanco 2017, 57).

Jedan od važnih uzroka nepostojanja ekvivalencije između određenih jezika može svakako biti i različit izvor s kojega su prevođeni biblijski tekstovi. Tako Mellado Blanco (2017, 65) govoreći o razlikama između španjolskih i njemačkih frazema biblijskoga podrijetla konstatira: „Dok je u njemačkome kao polazište služio Lutherov prijevod koji se temeljio na hebrejskome i grčkome izvorniku, španjolska verzija Biblije polazila je od Vulgate“.

Isto tako, mnogi biblijski citati „mogli su se s vremenom ugraditi u opće znanje pa ih je jezična zajednica počela upotrebljavati kao izvorne nacionalne frazeme i poslovice“ (Opašić 2013, 365).

Budući da frazemi biblijskoga podrijetla spadaju u internacionalizme, uz ekvivalenciju i podudarnost značenja, izvorom su također tzv. „lažnih prijatelja ili parova“. ${ }^{53}$ Ta je pojava zamjetna i u frazeologiji, osobito glede konotativnih značenja frazema (usp. Ljubičić 1994; Ljubičić 2011, 176).

Luque Nadal, uspoređujući frazeme biblijskoga podrijetla u engleskome i španjolskome upućuje na „la existencia de expresiones que presentan la misma forma en inglés y en español, pero cuyo significado varía ligeramente de una lengua a otra“ $(2010,281)$ i naziva ih „kulturološkim lažnim prijateljima (španj.falsos amigos culturológicos)“ (isto).

U frazeologiji je inače kalkiranje česta pojava (usp. Turk 1994; Ljubičić 2011; Turk 2013). Frazemi se često prevode na druge jezike jer „njihova sociokulturna uloga nadilazi značenjem jezičnu - te stoga relativno lako prelaze iz jednoga jezika u drugi““(Meisinger 1997).

Stoga svaka supostavna raščlamba između dvaju jezika zahtijeva „un estudio contrastivo y culturológico sistemático de las expresiones bíblicas en ambas lenguas“ (Luque Nadal 2010, 269).

U raščlambi frazema biblijskoga podrijetla u talijanskome i hrvatskome jeziku valja uzeti u obzir i zajedničku konstantu: uporabu latinskoga prijevoda Biblije sv. Jeronima kao jedinoga izvora biblijskih tekstova duže od jednoga tisućljeća i utjecaj latinskoga na oba jezika

\footnotetext{
${ }^{53} \mathrm{O}$ posuđivanju, kalkiranju i lažnim prijateljima ili parovima u talijanskome i hrvatskome usp. Ljubičić 2011.
} 
istodobno, ali i međusobne jezične dodire talijanskoga i hrvatskoga, odnosno možebitni utjecaj talijanske frazeologije na hrvatsku (usp. Jernej 1992 / 1993).

Međutim, pri tome se ne smije zaboraviti da se „hrvatski kao jezik maloga europskoga naroda - koji je sukladno svojim snagama živio u duhovnim kretanjima koja su ga okruživala i živo se uključivao u europske kulturne i civilizacijske tokove - umnogome oblikovao prema zadanim uzorima, ali je pri tom u standardološkoj svijesti bila jasno izražena sklonost da se stranojezični uzori ne prihvaćaju pasivno, nego se prema njima aktiviraju vlastite izražajne mogućnosti“ (Turk 2013, 11).

Budući da se gotovo do 20. stoljeća Biblija prevodila riječ po riječ, utjecaj latinskoga izvornika i na hrvatski i na talijanski jezik iznimno je velik.

Već je prijevod s grčkoga na latinski, tzv. Vetus latina ili Itala bio doslovno prenošenje, prevođenje riječ po riječ jer se vjerovalo da se tako mora postupati sa svetim tekstovima (usp. Renzi; Andreose 2003, 153). Isto se može reći i za djelomične i cjelovite prijevode Biblije tijekom stoljeća na talijanski i hrvatski jezik.

Katičić $(1992,195)$ uspoređuje Katančićev i Rupčićev prijevod Biblije i ustvrđuje da je Rupčićev prijevod iz 1968. godine puno „slobodniji“ i na višoj razini dok je Katančić „svaku riječ Vulgate zamijenio jednakovrijednom hrvatskom“.

Upravo je to bila praksa prevođenja Biblije koja je zacijelo doslovno prenosila i frazeme iz latinskoga na narodne jezike.

Glede utjecaja talijanske frazeologije na hrvatsku Turk $(2013,271)$ konstatira da je „niz frazema podudaran u hrvatskom i talijanskom jeziku“. To ipak ne isključuje mogućnost: „da su se pojedini frazemi u oba jezika razvili nezavisno jedan od drugoga. Mogućnost je poligeneze vrlo mala u primjerima u kojima postoji velika razlika u značenju frazema u odnosu na značenje koje bi proizlazilo iz njegovih leksičkih sastavnica“ (isto).

U svakom slučaju, uz veliki utjecaj latinskoga jezika na hrvatsku frazeologiju, bilo na frazeme u neprevedenome ili prevedenome obliku, uz utjecaj njemačkoga na kalkiranje frazema u hrvatskome te utjecaj kao jezika posrednika općenito, zamjetan je utjecaj i talijanskoga jezika (usp. Turk 2013, 269 - 274; Ljubičić 2011; Jernej 1992 / 1993). Ako se u novije vrijeme govori o utjecaju talijanskoga jezika koji je ranije bio toskanski varijetet koji je također imao utjecaja 
na hrvatski jezik, „, starije doba znatan je utjecaj i na polju jezika dolazio iz istočnih talijanskih pokrajina i Venecije preko dalmatinskih gradova i Dubrovačke republike“ (Jernej 1996, 266).

$\mathrm{S}$ francuskim jezikom hrvatski nije imao izravne dodire i uglavnom su općeeuropski frazemi koji su francuskoga podrijetla u hrvatski ušli preko posredničkih jezika. Unatoč velikomu utjecaju engleskoga na hrvatski jezik u posljednjim desetljećima, u frazeologiji se ne osjeća velik utjecaj kao primjerice u slučaju posuđenica i leksičkih prevedenica (usp. Turk 2013, 275).

\subsection{Nastanak biblijskih frazema}

Biblijski frazemi nastajali su na različite načine. Nekada su nastali izravno u nekome jeziku, nekada u dijalektima, a potom prenošeni u književni i standardni jezik, a nekada su preuzimani kalkiranjem iz drugih jezika.

Kao što je opisano u poglavlju 6, biblijski je jezik pridonosio nastanku frazema. To opet ne znači da su iscrpljene sve mogućnosti nastanka novih frazema biblijskoga podrijetla jer postoji još mnoštvo biblijskih epizoda i izraza koji su pogodni za razvoj frazema i koji će možda nekada u budućnosti biti izvorom novih frazema.

Földes navodi biblijske situacije koje su bile pogodne i mogle dovesti do nastanka frazema, a da do toga u europskim jezicima ipak nije došlo. Primjerice, stoljećima su se riječ po riječ prevodile skupine riječi vezane za rog. Za narod Staroga zavjeta „,budući da se radilo o polunomandskome pastirskom narodu, rog je ovna, jarca slovio simbolom snage“ $(1990,63)$.

U suvremenim prijevodima koji nisu doslovno prenošenje riječi i izraza s latinskoga, grčkoga ili hebrejskoga izvornika ta je frazeološka sveza ipak ostala na nekim mjestima. Primjerice, u Psalmu 132, 17 u hrvatskome prijevodu stoji: „Tu ću učiniti da izraste rog Davida“. „Učiniti da izraste rog komu“ znači 'dati snagu komu'. Naprotiv, uništenje moći predstavlja se kao „odbiti rog“, primjerice Jeremija 48, 25: „Odbijen je rog Moabu, mišica se njegova smrskala“; tal.“È stato frantumato il corno di Moab e il suo braccio è stato spezzato“; njem. „Abgehauen ist Moabs Horn, zerschmettert sein Arm“. Potom u njemačkome prijevodu Job 16, 15: „Mein Horn in den Staub gesenkt“. ${ }^{54}$ Međutim, frazemi su biblijskoga podrijetla

\footnotetext{
${ }^{54}$ Hrvatski primjeri preuzeti su iz prijevoda Biblije Biblija 1987, talijanski iz Bibbia 1997, a njemački iz Bibel 1991.
} 
toga tipa gotovo nepoznati u europskim jezicima i te frazeološke sveze u izvornim tekstovima Biblije, iako doslovno prevođene na razne jezike, nisu bile izvorom novih frazema sa značenjem koje imaju u biblijskim tekstovima. ${ }^{55}$

Budući da je Biblija utjecala i na frazeologiju i paremiologiju i jezik općenito, postoji više tipova izraza u kojima se može prepoznati taj utjecaj. Uz jednostavne riječi i pojmove, postoje i složene sveze i frazemi, slike i prispodobe, citati i poslovice, biblijske šale, parodije i travestije (usp. Földes 1990, 59).

Istraživanjem utjecaja Biblije na jezik i književnost bavili su se mnogi znanstvenici pa su i pristupi različiti.

Opašić (2013, 72 - 77) donosi više podjela biblizama (shvaćenih puno šire od frazema biblijskoga podrijetla), primjerice prema J. A. Balázsiju, A. Kerekjartou, J. A. Gvozdarevu, A. Bierichu i J. Matešiću, P. Mikiću i V. Suzaniću itd.

Vidović Bolt (2011, 44 - 45) donosi podjelu biblijskih frazema prema SpagińskaPruszak $(1998,79)$ :

1. „frazemi preuzeti iz prijevoda Biblije kao citati ili parafraze, a status su frazema stekli nakon završena procesa frazeologizacije,

2. frazemi koji su nastali pod utjecajem biblijskih tekstova (prispodoba, podataka, simbola),

3. frazemi koji su posljedica specifičnog ostvaraja u nekom jeziku pa su na taj način nastali novi, ustaljeni desemantizirani sklopovi od biblijskih izraza ili novi frazemi kojih je značenje suprotno od izvornoga biblijskog“.

Osim toga frazemi biblijskoga podrijetla mogu se podijeliti na primarne i sekundarne. Ta je podjela svakako korisna i dodatno pojašnjava odnose među frazemima biblijskoga podrijetla i u svim složenijim podjelama. Primarni frazemi bili bi ,frazeologizirani citati i parafraze“ (Vidović Bolt 2011, 45), a sekundarni „frazemi motivirani biblijskim prispodobama i simbolima“" (isto).

\footnotetext{
${ }^{55}$ Földes (1990, 63) navodi puno više mjesta u Bibliji primjerice: 1 Sam 2,1; 1 Sam 2,10; Ps 75, 11; Ps 89, 18; Ps 92,11; Ps 112, 9; Ps, 148, 14; Ez 29, 21; Sir 49,5 itd. u kojima se javljaju frazemi s imenicom rog. Međutim, u suvremenim službenim katoličkim prijevodima Biblije na hrvatski, njemački i talijanski oni nisu prevedeni doslovno i riječ rog uopće se ne spominje (usp. Biblija 1987; Biblija 2008; Bibbia 1997; Bibel 1991).
} 
Prema Chlebdi, Vidović Bolt $(2011,45)$ donosi i podjelu na stvarne biblijske frazeme (s potvrđenom poveznicom s biblijskim tekstom) i genetske biblijske frazeme te prema Walteru i Mokienku $(2009,11)$ na neposredne, s originalnom potvrdom u Bibliji i posredne, motivirane biblijskim prizorom, parabolom, događajem i sl.

Možemo ih podijeliti na izravne i neizravne. „Točne izvedenice aforizama i skupova riječi iz tekstova Svetoga pisma u svome završnom obliku mogu se nazvati izravnim biblizmima. Za razliku od njih neizravni biblizmi jedinice su nastale samostalnom kombinacijom biblijskih riječi, slika i sižea koje se ne nalaze u samom tekstu Biblije (usp. Walter; Mokienko 2009, 11 prema Opašić 2013, 77).

Mellado Blanco $(2017,57)$ frazeme biblijskoga podrijetla dijeli na doslovne i situacijske (španj. bibleísmos literales y bibleísmos situacionales). Doslovni su frazemi oni koji se preuzimaju iz biblijskih tekstova. Među njima mnogo je poslovica, a situacijski ne prenose doslovno frazu ili sintagmu iz Biblije, nego su njom inspirirani „y representan la condensación del contenido de un determinado pasaje bíblico de mayor o menor longitud“ (isto).

Postoji, dakle, više podjela frazema biblijskoga podrijetla i svaka od njih na poseban način rasvjetljava specifičnosti $\mathrm{i}$ bogatstvo biblijske frazeologije u jezicima. S obzirom na genetski i kronološki razvoj frazema biblijskoga podrijetla, mi ćemo ih prema Földesu (1990) podijeliti na:

1) frazeme preuzete izravno iz biblijskih tekstova

2) frazeme nastale prevođenjem biblijskih tekstova

3) frazeme nastale pod utjecajem biblijskih tekstova, ali nisu izravno preuzeti iz njih

4) frazeme nastale prema biblijskim predodžbama ili uzorcima, no bez neposrednoga odnosa prema Novome ili Starome zavjetu.

Predmetom naše raščlambe bit će uglavnom frazemi koji pripadaju prvim dvjema skupinama ili izravnim, stvarnim ili doslovnim frazemima biblijskoga podrijetla. Međutim, granice među tim skupinama često mogu biti vrlo nejasne i nije lako odrediti kojoj skupini neki frazem biblijskoga podrijetla točno pripada (usp. Földes 1990, 62). 


\subsubsection{Frazemi preuzeti izravno iz biblijskih tekstova}

U tu skupinu svrstat ćemo sve one frazeme biblijskoga podrijetla koji su izravno preuzeti iz biblijskih tekstova. Ti se frazemi uistinu prvi put pojavljuju u biblijskim tekstovima i razvili su se u frazeme u mnogim jezicima. Do toga je u različitim jezicima došlo u različitim epohama. Ti frazemi „odlikuju se najvećom međujezičnom ekvivalencijom“ (Földes 1990, 61).

Primjerice,

- u njemačkome: babylonische (Sprach) verwirrung

- u hrvatskome: glas vapijućega u pustinji

- u talijanskome: voce di uno che grida nel deserto.

\subsubsection{Frazemi nastali prevođenjem biblijskih tekstova}

U tu skupinu svrstavaju se frazemi biblijskoga podrijetla koji su nastali tek prevođenjem na druge jezike. Posrijedi su izrazi koji „opisuju simbolične čine“ (Földes 1990, 61) i koji su postali frazemima tek prevođenjem na druge jezike. Jezici primatelji time se obogaćuju izrazima koji u originalu još nisu slovili kao frazemi ili su se nalazili barem „u početnome stadiju frazeologizacije“ (isto).

Primjerice,

- u njemačkome: seine Hände in Unschuld waschen

- u hrvatskome: oprati / prati (umiti) ruke <kao Pilat $>$

- u talijanskome: lavarsene le mani.

\subsubsection{Frazemi nastali pod utjecajem biblijskih tekstova, ali nisu izravno preuzeti iz njih}

Postoje frazemi za koje je bjelodano da potječu u širemu smislu iz Biblije, ali nisu preuzeti doslovno iz biblijskih tekstova. Biblijske sveze ovdje su očito služile „kao predložak 
za tvorbu strukturno-semantički prikladnih izreka“ (Földes 1990, 61). Premda te frazeme ne nalazimo doslovno u biblijskim tekstovima, njihova je motivacija posvema jasna.

Primjerice,

- u njemačkome: von Pontius zu Pilatus laufen/jn. schicken

- u hrvatskome: slati koga od Poncija do Pilata ili slati koga od Heroda (Iruda) do Pilata

- u talijanskome: mandare qualcuno da Erode a Pilato ili mandare qualcuno da Ponzio a Pilato.

\subsubsection{Frazemi nastali prema biblijskim predodžbama ili uzorcima, no bez neposrednoga odnosa prema Novome ili Starome zavjetu}

Postoji i skupina frazema koji nemaju neposredan odnos sa starozavjetnim ili novozavjetnim tekstovima, ali koji su nastali prema biblijskim predodžbama ili uzorcima. Ti frazemi vrlo su heterogeni. U nekima je posrijedi „frazeološka igra“ i nerijetko imaju „humoristična obilježja i stilski su markirani“ (Földes 1990, 62). Često predstavljaju idiosinkratične fenomene i najčešće nemaju ekvivalente u drugim jezicima.

Primjerice,

- u njemačkome: vom Stamme Nimm sein

- u hrvatskome: ići apostolski

- u talijanskome: essere un'apocalisse. 


\section{METODOLOGIJA RADA}

U ovome drugom dijelu disertacije, pozabavit ćemo se raščlambom talijanskih i hrvatskih biblijskih frazema. Nakon prvoga, teorijskoga dijela i iznošenja našega poimanja frazeologije, frazema te frazemā biblijskoga podrijetla kao mikrosustava unutar frazemskoga inventara talijanskoga i hrvatskoga jezika najprije ćemo predstaviti metodologiju rada, a potom pojasniti načela kojih smo se držali prilikom sastavljanja korpusa ekscerpiranjem iz talijanskih i hrvatskih frazeoloških rječnika, online frazeoloških rječnika, frazeoloških radova o ovoj temi te iz ostale građe koja nam je bila na raspolaganju, ali i problemima oko razvrstavanja svih frazema koje smo prikupili.

Kod raščlambe strukture talijanskih i hrvatskih biblijskih frazema podijelit ćemo ih na fonetske riječi ili minimalne frazeme, sveze riječi i frazemske rečenice prema načelima radova Antice Menac (2007) i kako se to uglavnom čini u radovima na hrvatskome jeziku, a osobito ćemo se osvrnuti unutar sveza riječi na poredbene frazeme i na leksičke binome.

Frazemi često dopuštaju razne okazionalne preinake. U hrvatskome se to naziva paradigmatičnošću, dok njemačka tradicija u tome smislu rabi pojam modifikacija. Najprije ćemo se pozabaviti različnim pristupima modifikaciji i dosadašnjim teorijskim spoznajama, navlastito u literaturi na njemačkome i hrvatskome jeziku. Talijanske i hrvatske frazeme biblijskoga podrijetla analizirat ćemo u skladu s uvriježenom trodijelnom podjelom na frazeme nulte paradigmatičnosti, djelomične paradigmatičnosti i frazeme potpune paradigmatičnosti. Paradigmatičnost ćemo potkrijepiti primjerima na koje smo naišli pretraživanjem po internetu.

Paradigmatičnosti se pak suprotstavlja varijacija frazema. Glede varijantnosti talijanskih i hrvatskih frazema biblijskog podrijetla, u okviru ovoga rada pozabavit ćemo se, kako je uobičajeno u frazeološkim istraživanjima na hrvatskome jeziku, fonetskim, tvorbenim, sintaktičkim, leksičkim i leksičko-kvantitativnim inačicama te možebitnim kombinacijama više tipova inačica. Arealna frazeologija i najnovija istraživanja upozoravaju da je varijantnost puno veća nego što se to dosad mislilo te smo stoga uvjerenja da će u budućnosti biti novih prinosa toj temi i redefiniranja mnogih uvriježenih pojmova s time u svezi.

Semantička raščlamba frazema, uz sve dosad spomenuto, bitno pridonosi potpunijemu opisu frazema. Polazeći od teorijskih spoznaja Haralda Burgera (2015), analizirat ćemo načine čitanja frazema: samo jedan način čitanja, dva načina čitanja koji se jedan prema drugome 
odnose disjunktivno, dva načina čitanja koji se mogu istodobno ostvarivati te mješoviti tip, a tu podjelu iskoristit ćemo i u raspravi o remotiviranju.

Posvetit ćemo pozornost motiviranosti frazema i remotiviranju te semantičkoj autonomiji sastavnica i semantičkim obilježjima frazema kao što su polisemija, sinonimija, složenost, neodređenost i ekspresivnost, prema istraživanjima frazeologa kao što su Burger (2015), Chrissou (2000), Palm (1997) i na poseban se način osvrnuti na te pojave među frazemima biblijskoga podrijetla u talijanskome i hrvatskome jeziku te oprimjeriti teorijsku raspravu frazemima iz dvaju korpusa.

Na koncu će uslijediti raščlamba ekvivalentnosti talijanskih i hrvatskih biblijskih frazema, što svakako predstavlja glavni cilj svake supostavne raščlambe frazema dvaju jezika ili više njih.

U skladu sa spoznajama brojnih autora koji su se bavili međujezičnom usporedbom frazema (usp. Malá 1999; Chrissou 2000; Zeman 2006; Komenda-Earle 2009) najprije ćemo se osvrnuti na pojam ekvivalentnosti te na razine međujezične supostavne raščlambe: denotativno značenje, doslovno značenje, strukturu i stilsku vrijednost. Potom ćemo razmotriti modele ekvivalentnosti i tipove ekvivalentnosti, što je ujedno i glavni cilj svake supostavne raščlambe. Ekvivalentnost ćemo podijeliti na potpunu, djelomičnu i nultu ekvivalentnost talijanskih i hrvatskih biblijskih frazema, a unutar djelomične ekvivalentnosti formulirat ćemo različite podtipove: djelomičnu ekvivalentnost s gramatičkom specifičnošću (i uglavnom sa slikovnom ekvivalentnošću), sa semantičkom specifičnošću (i uglavnom slikovnom ekvivalentnošću) i djelomičnu ekvivalentnost s leksičko-gramatičkom specifičnošću (i funkcionalnom slikovnom ekvivalentnošću). Razmotrit ćemo i tip čisto semantičke ekvivalalentnosti. 


\section{PREDSTAVLJANJE KORPUSA}

Svako frazeološko istraživanje počinje ekscerpiranjem primjera potrebnih za raščlambu. Za potrebe ovoga rada u korpus smo uvrstili frazeme biblijskoga podrijetla u talijanskome i hrvatskome jeziku. Kao izvor poslužili su nam ponajprije jednojezični i višejezični frazeološki rječnici te online frazeološki rječnici koji se redovito ažuriraju kao i radovi koji su pisani o ovoj temi.

Za sastavljanje korpusa talijanskih frazema biblijskoga podrijetla poslužili smo se sljedećim rječnicima:

- In bocca al lupo! Espressioni idiomatiche e modi di dire tipici della lingua italiana (Di Natale; Zacchei 1996)

- Dizionario dei modi di dire della lingua italiana (Sorge 1997)

- $\quad$ Dizionario dei modi di dire (Pittàno 2014)

- Dizionario dei modi di dire (QRonline).

Za sastavljanje korpusa hrvatskih frazema biblijskoga podrijetla služili smo se sljedećim rječnicima:

- Frazeološki rječnik hrvatskoga ili srpskoga jezika (Matešić 1982)

- Hrvatsko-njemački frazeološki rječnik (Matešić i dr. 1988)

- Hrvatski frazeološki rječnik (Menac; Fink-Arsovski; Venturin, 2014)

- Hrvatsko-romansko-germanski rječnik poredbenih frazema (Fink-Arsovski 2015)

- Baza frazema hrvatskoga jezika (BFHJonline).

U obzir smo uzeli i sve radove posvećene ovoj temi na talijanskome i hrvatskome jeziku uz usporedbu s radovima na njemačkome i španjolskome jeziku te same prijevode Biblije na talijanski i hrvatski (usp. Biblija 1987; Bibbia 1997; Biblija 2008).

Premda mnogi frazeolozi paremiologiju uključuju u frazeologiju, u raščlambi nismo uzeli u obzir poslovice biblijskoga podrijetla zbog njihove posebnosti i brojnosti, što iziskuje posebnu raščlambu. Također smo iz korpusa isključili sve one frazeme za koje se može pretpostaviti da nisu biblijskoga podrijetla premda se za njih mislilo da se prvi put pojavljuju u 
prijevodima biblijskih tekstova. Posrijedi su somatizmi, pseudokinegrami i drugi tipovi frazema koji mogu biti biblijskoga podrijetla, ali isto tako mogu biti frazemi koji su se i ranije pojavljivali, a biblijski su prijevodi samo pripomogli njihovu širenju. Time ne isključujemo da su biblijski tekstovi imali puno veći utjecaj na frazeologiju europskih jezika nego što se općenito pretpostavlja i da su mnogi frazemi sa zoonimskim sastavnicama kao i somatizmi dobili svoj konačan oblik upravo u skladu s biblijskih predodžbama, međutim to je, barem zasad, stvar nagađanja i ne može biti kriterij supostavne raščlambe frazema biblijskoga podrijetla dvaju jezika.

Osobit je problem bio odvojiti tzv. kristijanizme od frazema biblijskoga podrijetla. Kada su posrijedi frazemi koji se odnose na svetce ili na neke kršćanske običaje, na papinstvo, svećenstvo ili monaštvo / redovništvo kao primjerice:

- tal. durare da Natale a Santo Stefano; stare coi frati e zappar l'orto; fare come le campane che chiamano alla messa e non entrano mai in chiesa

- hrv. košta (stoji) kao svetoga Petra kajgana; dospjeti (upasti) kao Pilat u Vjerovanje

lakše ih je bilo odvojiti od frazema biblijskoga podrijetla premda se u nekima pojavljuju osobe koje se spominju u Bibliji ili događaji iz Biblije kao sv. Petar, Pilat, Božić (ne kao blagdan, nego kao dan rođenja Kristova) i sv. Stjepan Prvomučenik, jasno je da su posrijedi frazemi čije je značenje nastalo pod utjecajem nabožne književnosti, pučke pobožnosti, kalendara, običaja, ustroja crkvenoga života i sl.

Međutim, puno je teže bilo odrediti kada su posrijedi frazemi biblijskoga podrijetla, a kada frazemi koje možemo nazvati „liturgizmima“, dakle frazemi koji su nastali zahvaljujući mjestu određenih pojmova, riječi, izreka, psalama koji se rabe u liturgiji, ali je njihovo značenje svojevrstan opis bogoslužnoga čina u kojemu se rabe.

Dok smo uvrstili u korpus frazem I amen (!): 'i gotovo (!), i gotova stvar (!)' jer se riječ amen često pojavljuje u biblijskim tekstovima, također i sigurno kao amen jer se to značenje itekako može izvesti iz biblijskih tekstova koje je puk redovito slušao u poslanicama i evanđeljima na pučkome jeziku, u hrvatskome pjevano svake nedjelje, isključili smo frazeme kao primjerice stići / stizati (doći / dolaziti) na amen: 'pojaviti se prekasno (neposredno pred završetak), stići na kraj čega', jer se u ovome slučaju misli na liturgiju i druge bogoslužne čine koji završavaju obično riječju amen. Također i u talijanskome postojali su primjeri koje nije lako bilo dodijeliti. Primjerice cantare il de profundis a qualcuno o qualcosa nismo uvrstili u 
korpus. Iako su posrijedi početne riječi 130. psalma, dakle riječi preuzete izravno iz Biblije, značenje držati koga što izgubljenim ili mrtvim izvodi se iz činjenice da se taj psalam moli za pokojne tako da je ovo značenje početnih riječi 130. psalma nastalo na temelju njegove uporabe u liturgiji Crkve i u molitvama za pokojne.

Nadasve je zanimljivo postojanje frazema $\mathrm{u}$ talijanskome koji su nastali krivim razumijevanjem latinskih riječi. Primjerice frazem farne quanto Nemo nastao je krivim razumijevanjem latinske zamjenice nemo koja je u mašti puka držana osobom. U frazeološkim rječnicima navodi se da je biblijskoga podrijetla jer se u tekstovima poslanica i evanđelja ta zamjenica često spominje.

Valja naglasiti da je riječ o korpusu koji je stvoren za sinkronijsku supostavnu raščlambu mikrosustava dvaju jezika premda su u frazeološke rječnike uvršteni i primjeri koji se već dulje rabe. Neki su već i zastarjelice ili se pojavljuju samo u književnim korpusima, tako da i u ovoj sinkronijskoj raščlambi imamo i jedan vid dijakronije. $\mathrm{K}$ tome, riječ je o usporedbi frazema $\mathrm{u}$ dvama standardnim varijetetima iako dijalekti, lokalni i regionalni obiluju frazemima biblijskoga podrijetla, ali to nije predmetom ovoga rada. U skladu s time nismo uključili neke frazeme biblijskoga podrijetla na koje smo naišli u radovima, a čija se uporaba veže isključivo za govor nekoga kraja.

Kako su izrazi, poslovice i frazemi koji potječu iz Biblije jako davno ušli u jezik i kulturu europskih naroda, pustili su duboke korijene. Tako neki frazemi koji postoje u hrvatskome, ušli su dakle u opći jezik, u talijanskome nemaju jednakovrijednice, ali se rabe u poslovicama biblijskoga podrijetla ili se rabe za naziv biblijskih motiva u umjetnosti itd. U ovome radu ograničili smo se isključivo na frazeme biblijskoga podrijetla.

Isto tako, neki izrazi koje bismo mogli uvrstiti u frazeologiju rabe se u svetopisamskim tekstovima i u tumačenjima tih tekstova (propovijedi, razmatranja, teološke rasprave), koji se danas mogu pronaći na internetu, no ne možemo ih držati dijelom općega jezika. Nije bilo lako razgraničiti ih od ostalih koji su češći u uporabi i stoga smo se uglavnom držali frazeoloških rječnika i radova posvećenih toj temi. Posrijedi su dakle primjeri koji su uglavnom leksikografske jedinice: normativni, leksikografski etablirani frazemi. 


\section{STRUKTURNA RAŠČLAMBA FRAZEMA BIBLIJSKOGA PODRIJETLA U TALIJANSKOME I HRVATSKOME JEZIKU}

Glede strukturne raščlambe frazema u skladu s načelima hrvatske frazeološke tradicije frazemi se dijele na tri tipa: fonetske riječi, sveze riječi i frazemske rečenice. ${ }^{56}$ Danas frazeolozi spominju i četverostupanjsku podjelu ${ }^{57}$ na minimalne frazeme, sveze riječi, rečenične frazeme i dodaju još i polusloženice (usp. Budimir 2020, 89).

U ovome radu frazeme biblijskoga podrijetla podijelili smo u skladu s trostupanjskom podjelom s posebnim osvrtom na leksičke binome.

\subsection{Fonetska riječ ili minimalni frazem ${ }^{58}$}

Fonetska riječ sastoji se od jedne punoznačne riječi i jedne ili više nepunoznačnih riječi. Glede frazema biblijskoga podrijetla u talijanskome i hrvatskome jeziku naišli smo na malobrojne primjere frazema koji imaju oblik fonetske riječi, primjerice:

- u talijanskome: nije bilo primjera

- u hrvatskome: i amen!; ni (niti) za jotu.

U obama slučajevima zastupljena je najčešća struktura: veznik+prijedlog+imenica, ${ }^{59}$ ali i rijetko posvjedočena veznik + usklik.

To očito ne vrijedi samo za frazeme biblijskoga podrijetla. I u usporedbama drugih mikrosustava minimalni su frazemi uglavnom malobrojni (usp. Vidović Bolt 2011, 24; Budimir 2020, 90).

\footnotetext{
${ }^{56}$ Termine smo preuzeli prema Vidović Bolt $(2011,22)$. U literaturi se može naići i na druge termine, osobito za svezu riječi: frazemi-sintagme i frazemske sintagme, skup riječi itd. (usp. Melvinger 1989; Turk 1998; FinkArsovski 2002) te za frazemske rečenice: frazem rečenica, frazem-rečenica, frazem sa strukturom rečenice (usp. Vidović Bolt 2011, 23), frazemi s rečeničnom strukturom (Kovačević 2012, 58).

${ }^{57}$ Ovu podjelu donose primjerice Fink-Arsovski i sur. $(2016,6)$ i Vidović Bolt $(2017,8)$.

${ }^{58}$ Pojam minimalni frazem pojavljuje se u novijim frazeološkim rječnicima primjerice Fink-Arsovski i sur. (2016, 5) i Vidović Bolt $(2017,8)$. Spominje ga i Budimir i napominje: „Naziv minimalni frazem koristi se u recentnim frazeološkim rječnicima i zamijenio je dosadašnji termin frazem fonetske riječi“ $(2020,89)$.

${ }^{59}$ Usp. Budimir 2020, 90.
} 


\subsection{Sveza riječi}

Sveza riječi u frazeološkome inventaru nekoga jezika uglavnom spada u najčešći frazeološki tip i sastoji se najmanje od dviju punoznačnih riječi. Uz punoznačne riječi može biti jedna ili više nepunoznačnih (usp. Vidović Bolt 2011, 23).

Prema morfološko-sintaktičkome kriteriju moguće ih je ,podijeliti na nekoliko tipova, a s obzirom na vezu koja se ostvaruje među frazeološkim sastavnicama sveze razlikuju se: nezavisni i zavisni tip (imenični, glagolski, pridjevni i priložni)“(Budimir 2020, 91).

Taj tip frazema zastupljen je među frazemima biblijskoga podrijetla i u talijanskome i u hrvatskome jeziku, primjerice:

- u talijanskome: bacio di Giuda; fare il casto Giuseppe; povero in canna

- u hrvatskome: Judin poljubac; ležati kao Lazar; razmetni (rasipni, izgubljeni, bludni) sin; jak kao Samson.

Osobito bismo istaknuli dva tipa sveza riječi: leksičke binome, a među njima osobito binome s vlastitim imenima i sveze riječi poredbene strukture.

Među frazemima biblijskoga podrijetla zastupljeno je i nekoliko leksičkih binoma. Govorimo o leksičkim binomima „kada su posrijedi ili dvije različite riječi iste vrste, riječi koje su spojene veznikom ili ø, koje su (više ili manje) određene u svom redoslijedu, kada je posrijedi (više ili manje) ireverzibilna veza ili ako dvije identične riječi koje su ulančane veznicima ili prijedlozima tvore čvrstu vezu“ (Burger; Buhofer; Sialm 1982, § 2.3.6.), primjerice:

- u talijanskome: l'alfa e l'omega; dall'alfa all'omega; con tutti i crismi <e sacrismi>; occhio per occhio $-<$ dente per dente $>$

- u hrvatskome: alfa i omega; slovo i duh; vezati i driješiti; oko za oko - <zub za zub>; prah i pepeo.

Među binomima zastupljenima u korpusu frazema biblijskoga podrijetla zamjetni su i binomi s vlastitim imenima (i jedan primjer s nazivima naroda koji se u talijanskome piše malim početnim slovom), primjerice:

- u talijanskome: cominciare da Adamo ed Eva; mescolare ebrei e samaritani; mandare da Erode a Pilato (da Ponzio a Pilato); fare da Marta e da Maddalena; Sodoma e Gomorra 
- u hrvatskome: od Adama i Eve; od Adama do Eve; borba Davida i Golijata; slati koga od Heroda do Pilata (od Iruda do Pilata; od Poncija do Pilata); Sodoma i Gomora.

U literaturi se na hrvatskome u ovome surječju ne spominju leksički binomi, nego ih Budimir svrstava pod nezavisne sveze riječi i definira ih kao nezavisne skupove zastupljene manjim brojem frazema „čije sastavnice nisu u zavisnome odnosu“ $(2020,91)$.

Posrijedi su koordinativni binomi biblijskoga podrijetla prema shemi $A$ i $B$ (tal. A e B), u nekoliko slučajeva imamo prijedložnu shemu od $A$ do B (tal. da A a B); A za B (tal. A per B). Riječ je o binomima imeničnoga podtipa. Samo je jedan leksički binom glagolskoga podtipa, i to u hrvatskome. Imenice su ujedno i najzastupljenija vrsta riječi u leksičkim binomima.

U svim primjerima imeničnoga podtipa imenice su u istome broju, jednini, osim u jednome primjeru gdje su obje sastavnice u množini. Rod je uglavnom isti, u dvama primjerima imamo različne gramatičke rodove.

Ekscerpirani binomi biblijskoga podrijetla zanimljivi su navlastito sa semantičkoga stajališta, što u okviru ovoga rada ne možemo obrađivati.

Slijed je sastavnica tih binoma ponajčešće strogo određen ili se u nekim primjerima daje prednost jednomu slijedu. Promjenom slijeda u većini slučajeva izgubili bismo prepoznatljivo frazeološko značenje i imali bismo posvemašnju semantičku prozirnost: primjerice u tal. dall'omega all'alfa; mescolare samaritani ed ebrei ili u hrv. duh i slovo, od omege do alfe ovo značenje ne bi bilo frazeološko.

Nezavisnim svezama riječi suprotstavljaju se zavisne sveze. Sveze riječi zavisnoga tipa, kako je već spomenuto, dijele se na imenične, glagolske, pridjevne i priložne te rjeđe brojevne i zamjenične (usp. Vidović Bolt 2011, 23; Budimir 2020, 92).

Imenične sveze riječi zastupljene su u obama korpusima. Posrijedi je veza ,imenice s nekom drugom imenskom riječju ili prijedložnim izrazom“ (Budimir 2020, 101):

- u talijanskome: arca di scienza; torre di Babele; offerta di Caino; segno di Caino; amaro calice

- u hrvatskome: kula Babilonska; dolina suza (plača); Evina kći; Abrahamove godine; istočni grijeh. 
Zastupljeni su različni podtipovi ovoga strukturnoga tipa kao primjerice:

- imenica + imenica

- $\quad$ imenica + imenica (u genitivu) u hrvatskome ili

- imenica + prijedlog di + imenica u talijanskome, potom

- $\quad$ imenica + pridjev ili pridjev + imenica

- zamjenica + imenica

- $\quad$ prijedlog + imenica + imenica (u genitivu) itd.

Glagolske sveze riječi također su zastupljene. Njima se izriče radnja, stanje i zbivanje pri čemu glagolska sastavnica upravlja ostalim dijelovima sveze (usp. Budimir 2020, 92).

Brojni su u obama korpusima:

- u talijanskome: gridare il cruciffigge; porgere l'altra guancia; lavarsene le mani; portare il ramo d'olivo; pagare nella valle di Giosafat

- u hrvatskome: ići kao janje na klanje; iščupati žito s kukoljem; čitati (očitati) komu levite; zbrisati koga s lica zemlje; okrenuti drugi obraz.

U obama jezicima strukturni tip glagolskih frazema sveze riječi ima različne podtipove, a najbrojniji su:

- glagol + prijedlog + imenica ili

- $\quad$ glagol + imenica + prijedlog + imenica

odnosno u hrvatskome

- glagol + imenica u akuzativu + prijedlog + imenica ili

- glagol + imenica u akuzativu + imenica u nekome padežu (primjerice genitivu).

Posebice bismo se željeli osvrnuti i na sveze riječi poredbene strukture ili komparativne frazeme. Komparativni frazemi odnosno frazeološke usporedbe sastoje se od usporedbe sastavnica. Uglavnom su „dvojne ili, češće, trojne strukture jer se u njima poredbenim veznikom kao B-dijelom, A-dio (comparandum) uspoređuje s C-dijelom (tertium comparationis)““ (Vidović Bolt 2011, 23), primjerice: 
- u talijanskome: essere atteso come il Messia; essere nero come l'anima di Giuda; essere come san Tommaso

- u hrvatskome: ići kao janje na klanje; ležati kao Lazar; čekati kao Mesiju koga.

Neke sveze riječi poredbene strukture ne sadrže A-dio, primjerice:

- $\quad$ u talijanskome: vecchio come l'arca di Noè ${ }^{60}$ vecchio come Matusalemme

- u hrvatskome: strpljiv kao Job; kao truba jerihonska; star kao Metuzalem; mudar kao Salamun.

Komparativne frazeme biblijskoga podrijetla odlikuje izrazita ekspresivnost i ekscerpirani primjeri često sadrže onimske sastavnice u obama jezicima, kadšto bez jednakovrijednica u drugome jeziku. Moguće je da su mnogi drugi komparativni frazemi u suvremenome talijanskom i hrvatskom jeziku koji nisu uvršteni u korpus inspirirani svetopisamskim tekstovima. Frazemi toga tipa mogu biti posvema idiomatski (idiomi), djelomično idiomatski i neidiomatski.

Ostali podtipovi sveza riječi rijetki su u obama korpusima.

\subsection{Frazemska rečenica}

Riječ je o frazemima koji imaju strukturu rečenice. Ta rečenica može biti samostalna, a može se uključivati u drugu rečenicu ili širi kontekst (usp. Kovačević 2012, 58).

Prema primjerima u korpusu talijanskih i hrvatskih frazema možemo ih podijeliti na dvodijelne rečenice koje imaju izrečen subjekt i predikat, rečenice s neizrečenim (skrivenim) subjektom i eliptične rečenice (usp. Kovačević 2012, 59 - 62).

- U talijanskome:

Bussate e vi sarà aperto.

Dar a Cesare quel che è di Cesare.

Molti sono i chiamati.

Come Dio comanda.

\footnotetext{
${ }^{60}$ Ovo je inačica frazema (essere) (vecchio) come l'arca di Noè.
} 


\section{Chiamate Erode!}

$<$ Niente di nuovo > sotto il sole!

Occhio per occhio, <dente per dente >!

chi di spada ferisce...

Gli ultimi saranno i primi.

Beati gli ultimi!

Vade retro Satana!

Vox populi, vox dei.

- u hrvatskome:

$<$ To je> kao amen.

Kako Bog zapovijeda.

Dokje Bog <još> po zemlji hodao.

Dati caru carevo, <a Bogu Božje >.

Gospod je pozvao koga k sebi.

(Ne) zna ljevica što (mi) čini (radi) desnica.

Teče med i mlijeko.

(Ništa novo) pod suncem.

Pala je komu koprena (mrena, veo) s očiju.

Nije komu pala (spala) ni vlas (dlaka) s glave.

$<$ Oko za oko>, zub za zub.

Raščlambom korpusa ustvrdilo se da su u korpusu frazema biblijskoga podrijetla zastupljena sva tri tipa frazema: fonetske riječi ili minimalni frazemi, sveze riječi i frazemske rečenice. U korpusu talijanskih frazema nije bio ni jedan primjer fonetske riječi, a zastupljena su ostala dva tipa: sveze riječi i frazemske rečenice.

U hrvatskome korpusu pronađena su dva frazema koji pripadaju tipu fonetske riječi, od kojih je jedan frazem s dvjema inačicama. Jedan frazem ima tipičnu strukturu minimalnoga frazema, a drugi rjeđu. Međutim, kako je već gore spomenuto, taj je tip dosta rijedak u frazemskome inventaru uopće. 
Najbrojniji tip i u hrvatskome i u talijanskome jesu sveze riječi. Zastupljen je i nezavisni i zavisni tip sveza riječi.

Pod nezavisnim tipom osobito smo se osvrnuli na leksičke binome. U korpusu obaju jezika potvrđeni su leksički binomi i to 9 u talijanskome korpusu, a 10 u hrvatskome, od kojih 5 binoma i u talijanskome i u hrvatskome s vlastitim imenima. Uglavnom je riječ o koordinativnim imeničnim binomima prema shemi $A$ i $B$ (tal. $A$ e B).

Među nezavisnim svezama riječi najveći je broj glagolskih, a potom imeničnih sveza riječi, a i jedan i drugi strukturni tip imaju brojne strukturne podtipove.

I u talijanskome i u hrvatskome jeziku naišli smo na više frazemskih rečenica, $12 \mathrm{u}$ talijanskome i $11 \mathrm{u}$ hrvatskome i to:

- $\quad$ tri neoglagoljene (krnje) rečenice u talijanskome i dvije u hrvatskome

$<$ Niente di nuovo $>$ sotto il sole! (Ništa novo) pod suncem.

Occhio per occhio, <dente per dente>.

$<$ Oko za oko>, zub za zub.

Beati gli ultimi!

te također inačicu jedne frazemske rečenice koja se pojavljuje kao neoglagoljena

$<$ To je $>$ kao amen.

- $\quad$ po jednu jednostavnu rečenicu u talijanskome i hrvatskome

Chiamate Erode! Gospod je pozvao koga $k$ sebi.

- $\quad$ dvije jednostavne rečenice $s$ imenskim predikatom $u$ talijanskome $\mathrm{i}$ jednu $\mathrm{u}$ hrvatskome

Molti sono i chiamati. $\quad<$ To je> kao amen.

Gli ultimi saranno i primi.

- $\quad$ tri bezlične rečenice u hrvatskome

Pala je komu koprena (mrena, veo) s očiju.

Nije komu pala (spala) ni vlas (dlaka) s glave.

Teče med i mlijeko <gdje>. 
- jednu zavisnu rečenicu $u$ talijanskome (načinska surečenica) i dvije $u$ hrvatskome (načinska i vremenska surečenica)

Come Dio comanda.

Kako Bog zapovijeda.

Dokje Bog <još> po zemlji hodao.

- $\quad$ po jednu nezavisnosloženu rečenicu u talijanskome i hrvatskome

Bussate e vi sarà aperto.

Dati caru carevo, <a Bogu Božje>.

- $\quad$ jednu zavisnosloženu rečenicu u talijanskome

Dar a Cesare quel che è di Cesare.

i jednu zavisnosloženu rečenicu u hrvatskome

(Ne) zna ljevica što (mi) čini (radi) desnica.

i jednu krnju zavisnosloženu rečenicu u talijanskome

chi di spada ferisce...

Dvije frazemske rečenice koje su uvrštene u popis talijanskih frazema biblijskoga podrijetla na latinskome su jeziku, što nije rijetkost i u talijanskim frazeološkim rječnicima gdje se može naići na više frazema na latinskome koji se rabe u suvremenome talijanskom jeziku i oni ipak nemaju vrijednost ksenofrazema kao frazemi iz ostalih jezika. Riječ je o jednoj jednostavno proširenoj i jednoj neoglagoljenoj (bespredikatnoj) rečenici.

Frazemske rečenice najčešće su skraćene biblijske poslovice koje postoje u obama jezicima, ali gdjekad kao frazem biblijskoga podrijetla samo u jednome.

Riječ je dakako o raščlambi novijega vremenskog presjeka dvaju jezika i to uglavnom standardnoga varijeteta. Istraživanja s povijesnoga ili arealnoga stajališta svakako će dopuniti naše spoznaje. 


\section{PARADIGMATIČNOST TALIJANSKIH I HRVATSKIH FRAZEMA BIBLIJSKOGA PODRIJETLA}

U poglavlju o temeljnim obilježjima frazema govorilo se o važnosti ustaljenosti ili stabilnosti strukture kao jednoga od najvažnijih načela (uz polileksikalnost, idiomatičnost i leksikaliziranost) pri definiranju sveze riječi frazeološkom (usp. § 4.2.). Napomenuli smo također da se stabilnost strukture ne može shvaćati u apsolutnome smislu. Ustaljenost (stabilnost strukture) i varijabilnost predstavljaju komplementarne kategorije unutar frazeologije (usp. Burger; Buhofer; Sialm 1982, 67). U skladu s novijim istraživanjima posvemašnja je leksička stabilnost zamjetna samo u malenome broju primjera jer većina frazema u određenim granicama pokazuje mogućnost zamjena i preinaka. $\mathrm{S}$ time u svezi važno je istaknuti dva tipa ostvaraja varijabilnosti koji se tiču različnih vidova relativiziranja stabilnosti strukture: varijaciju i modifikaciju (usp. Burger 2015, 22). Frazemi se dakle mogu mijenjati ovisno o surječju u kojemu je nađu. Njemački frazeolozi tu pojavu nazivaju modifikacijom. ${ }^{61} \mathrm{U}$ hrvatskoj literaturi govori se o paradigmatičnosti frazema. ${ }^{62}$

Prema Burgeru $(2015$, 24) za razliku od varijacije kod koje je riječ o uvriježenim pojavama, modifikacija je „okazionalna preinaka frazema, načinjena za potrebe jednoga teksta“. Fink-Arsovski $(2002,21)$ također napominje da se „kod varijantnosti mijenja oblik samog frazema neovisno o kontekstu, a paradigmatičnost je uvjetovana upravo promjenom oblika pojedine komponente u zavisnosti od konteksta“. Posrijedi su dakle promjene u izvanjezičnome kontekstu, na paradigmatskoj osnovi. Te promjene ne narušavaju čvrstu strukturu frazema (usp. Vidović Bolt 2011, 26).

Prema Fleicheru $(1997,263)$ modifikacija se ostvaruje zahvatima „u relativno 'stabilnu' unutarnju strukturu frazema, poglavito supstitucijom i ekspanzijom, redukcijom i kontaminacijom“.

Chrissou $(2000,194)$ napominje da je pri tome „karakterističan otklon od leksičke i morfosintaktičke strukture uvriježenoga, kodificiranoga frazema. Modifikacija se od uvriježene varijacije razlikuje u tome da nije pohranjena u leksikonu. Strogo odvajanje između

\footnotetext{
${ }^{61}$ I u hispanističkoj frazeološkoj literaturi, unutar pojma „variabilidad“ razlikuju se dva tipa: „variación“ i „modificación“ (usp. Corpas Pastor; Mena Martínez 2003, § 3.).

${ }^{62}$ Pojam modifikacije spominje se kadšto i u literaturi na hrvatskome. Ivana Filipović Petrović $(2018,75)$ govori o varijantama i modifikacijama frazema.
} 
(uvriježene) varijacije i (okazionalne) modifikacije u nekim se slučajevima ne može ostvariti jer između tih dviju kategorija postoje nejasni prijelazi“.

U novijoj frazeološkoj literaturi vlada suglasje da kod modifikacije frazema nije posrijedi odmak od standardne jezične uporabe, nego štoviše tipičan način porabe frazema (usp. Chrissou 2000, 194). Prema Gréciano $(1983,237)$ u naravi je frazema ,govornika pozvati / izazvati na kreativne prelaske granica“. Upravo su frazemi za razliku od drugih jezičnih sredstava pogodni za jezičnu igru pri čemu polileksikalnost, ustaljena struktura, idiomatičnost i ekspresivnost itekako potiču na igranje jezikom. Kontekst pri tome služi kao ,posrednik između razine izraza i sadržaja“ (Chrissou 2000, 195), a upravo taj vid frazeološke promjenjivosti pokazuje ,zašto su upravo ovi sekundarni znakovi za svoje komunikativne zadaće osobito prikladni, upravo specijalizirani“ (Černyševa 1980, 310 prema Chrissou 2000, 195).

Frazeme domišljamo, karikiramo, s njima se igramo i aktualiziramo neočekivano značenje (usp. Donalies 2009, 18).

Dakle, pokadšto nije lako odrediti jesu li posrijedi inačice ili modifikacije frazema. U današnjim tekstovima i u sredstvima javnoga priopćavanja kao i u beletristici modifikacije imaju središnju ulogu pri uporabi idioma (usp. Burger 2015, 25).

Prema Fink-Arsovski $(2002,21)$ s obzirom na paradigmatičnost frazeme možemo podijeliti na frazeme nulte paradigmatičnosti, frazeme djelomične paradigmatičnosti i frazeme potpune paradigmatičnosti.

\subsection{Frazemi nulte paradigmatičnosti}

Pod nultom paradigmatičnošću podrazumijeva se poraba frazema $\mathrm{u}$ njegovu kanonskome obliku pri čemu nisu moguće nikakve preinake (usp. Vidović Bolt 2011,26).

U frazeme nulte paradigmatičnosti ${ }^{63}$ možemo uvrstiti frazeme biblijskoga podrijetla koji imaju strukturu fonetske riječi te neke leksičke binome, primjerice:

\footnotetext{
${ }^{63}$ U nekim primjerima koje navodimo uvrštena je jedna inačica frazema. Druga ne bi pripadala frazemima nulte paradigmatičnosti.
} 
- u talijanskome: l'alfa e l'omega; dall'alfa all'omega; occhio per occhio, <dente per dente $>$

- u hrvatskome: $i$ amen; ni (niti) za jotu; od Adama i Eve; od Adama do Eve; borba Davida i Golijata; oko za oko, <zub za zub>; prah i pepeo.

Tomu možemo pridodati i ostale sveze riječi

- u talijanskome: in costume adamitico (evitico); con tutti i crismi $<$ e sacrismi $>$; ai tempi di Noè; Sancta sanctorum; col sudore della fronte

- u hrvatskome: u Adamovu (Evinu) kostimu; Abrahamove godine; u znoju lica svoga; prst Božji.

U frazeme nulte paradigmatičnosti možemo ubrojiti i neke frazemske rečenice:

- u talijanskome:

Molti sono i chiamati.

Come Dio comanda.

$<$ Niente di nuovo $>$ sotto il sole!

chi di spada ferisce...

te dvije frazemske rečenice na latinskome koje pripadaju talijanskomu korpusu:

Vade retro Satana.

Vox populi, vox dei.

- u hrvatskome:

$<$ To je $>$ kao amen.

Kako Bog zapovijeda.

Dokje Bog <još> po zemlji hodao.

(Ne) zna ljevica što (mi) čini (radi) desnica.

$<$ Ništa novo $>$ pod suncem. 


\subsection{Frazemi djelomične paradigmatičnosti}

Za razliku od frazema nulte paradigmatičnosti koja ne dopuštaju nikakve preinake, frazemi djelomične paradigmatičnosti pod utjecajem morfoloških ili semantičkih čimbenika dopuštaju određene preoblike. ${ }^{64}$

Glede imeničnih sastavnica u poredbenim frazemima zamjetno je da mijenjaju broj:

- I discepoli devono andare come agnelli fra i lupi.

Poredbeni pridjevski frazemi također pokazuju promjene roda i broja, a u hrvatskome i padeža.

- Spinte dal vento marino c'erano arrivate tra capo e collo [...] certe nubi nere come l'anima di Giuda.

- Decifro solo che i miei prossimi capitoli sono ,attesi come il Messia“.

- A njegova duša bi primljena u krilo Abrahamovo.

- Neki od ovih ukrasa stari su kao Metuzalem.

I druge sveze riječi imeničnoga i pridjevnoga podtipa također pokazuju promjene:

- Poveri in canna, ma sono le persone più felici che conosca. (povero in canna)

- Quanti altri baci di Giuda vedremo?! (bacio di Giuda)

- Mi smo svi braća u Kristu. (brat u Kristu)

- Vukovima u janjećoj koži nije stalo da nahrane ovcu, nego samo sebe. (vuk u janjećoj koži)

Glede glagolskih frazema možemo zamijetiti samo promjenu glagolske sastavnice:

- Tamo nitko ne će koristiti plodove tuđega rada niti će ispaštati za tuđe grijehe. (ispaštati za tuđe grijehe)

\footnotetext{
${ }^{64}$ Primjere za djelomičnu i potpunu paradigmatičnost pronašli smo na internetskoj tražilici Google.
} 


\subsection{Frazemi potpune paradigmatičnosti}

Za razliku od prvih dvaju tipova, frazemi potpune paradigmatičnosti ne pokazuju nikakva morfološka ni sintaktička ograničenja. Najčešće su posrijedi frazemi koji pripadaju kategoriji sveze riječi, i to pobliže imenskoga podtipa. U korpusu ekscerpiranih frazema naišli smo samo na svezu imenice i pridjeva, odnosno pridjeva i imenice:

- Ma quelli che invece non hanno fatto il loro dovere, i figlioli prodighi, non sono nelle stesse condizioni. (figliol prodigo)

- Fin dall'inizio dei negoziati abbiamo detto chiaramente quali devono essere le pietre angolari di un bilancio europeo funzionale ed efficiente. (essere la pietra angolare)

- Pobožno ruho u koje su uvijene njihove rečenice samo su obijeljeni grobovi koji u sebi kriju mrtvilo oholosti. (biti obijeljen grob)

- On naglašava kako nije objektivno tražiti takva salamonska rješenja. (salamonsko rješenje)

Talijanski i hrvatski frazemi biblijskoga podrijetla pokazuju sve tri vrste paradigmatičnosti. Poradi svoje ekspresivnosti i slikovitosti frazemi biblijskoga podrijetla upravo su prikladni za različne oblike modifikacije, prilagođavaju se svim funkcionalnim stilovima i, premda neki zastarijevaju i prestaju se porabiti, drugi dobivaju na važnosti i vitalnosti. A nisu rijetki ni primjeri frazemskih oživljenica.

Najzastupljeniji tip paradigmatičnosti jest djelomična paradigmatičnost, a samo nekoliko frazema pripada tipu potpune paradigmatičnosti. Uglavnom su posrijedi promjene roda i broja u talijanskome, a u hrvatskome $\mathrm{k}$ tome i promjene padeža jer talijanski ne poznaje imeničnu fleksiju. S obzirom na činjenicu da je među frazemima biblijskoga podrijetla velik broj onimskih frazema, često nije moguće mijenjati rod i broj pa to itekako utječe na smanjenje opsega modifikacije.

Nulta paradigmatičnost zastupljena je u samo nekoliko primjera u obama jezicima, uglavnom u frazemima koji imaju oblik fonetske riječi, u nekim svezama riječi, među kojima se pojavljuju i leksički binomi te u nekoliko frazemskih rečenica. Valja pak pripomenuti da nije 
isključeno da bi se i neki od tih primjera mogli pojaviti s modifikacijama iako tijekom pretraživanja nismo naišli na takve primjere.

Različne modifikacije moguće su upravo zbog činjenice da se biblijski tekstovi u istome ili sličnome obliku stalno čitaju i citiraju i da je određena biblijska slika uglavnom jasna. Nisu posrijedi drevni običaji ili srednjovjekovni pravni propisi koji su pali u zaborav i koje mnogi frazemi pohranjuju a da im se bez objašnjenja stručnjaka ne razumije značenje. Riječ je o tekstovima koje kršćani drže Riječju Božjom i koji u njihovu životu zauzimaju posebno mjesto, a u bogoslužnim činima također imaju povlašteno mjesto, ali i potrebno tumačenje. 


\section{VARIJANTNOST TALIJANSKIH I HRVATSKIH FRAZEMA BIBLIJSKOGA PODRIJETLA}

Usprkos tomu što je ustaljenost važan kriterij pri definiranju frazema, u rječnicima se frazemi ne navode samo u jednome obliku nego se navode s dvjema inačicama ili čak i više sličnih inačica. Kao što je spomenuto u prošlome poglavlju, varijacija, koja također predstavlja relativiziranje stabilnosti strukture, za razliku od paradigmatičnosti ili modifikacije od koje je gdjekad i nije lako odvojiti, predstavlja uvriježene preinake frazema. Prema Palm $(1997,71)$ pod varijantama frazema podrazumijevamo „leksikografski etablirane, u frazeoleksikonu pohranjene, uvriježene mogućnosti promjena u leksemskome sastavu jednoga frazema“. Varijacija je „manevarski prostor unutar kojega su moguće formalne preinake frazema a da se ne izgubi frazeološko značenje, pri čemu se ovaj manevarski prostor može i treba leksikografski obuhvatiti“ (Burger; Buhofer; Sialm 1982, 67). Posljedica procesa varijacije jest varijantnost frazema.

Svima koji su se bavili prikupljanjem frazeološkoga blaga posvema je jasno da istodobno postoje brojne inačice jednoga frazema, bilo da su posrijedi istoznačnice ili bliskoznačnice. Frazeološki rječnici uzimaju koliko je moguće u obzir stvaranje varijanata u onoj mjeri u kojoj su poznate leksikografu. Nerijetko ćemo doživjeti da je frazem u materinskome jeziku koji je nama osobno poznat u nekome obliku, čak i iskusnomu frazeologu posvema nepoznat ili mu je pak poznata samo neka njegova inačica. Konvencionaliziranje određenih inačica u slučaju frazema može biti izraženije zemljopisno, sociolektalno itd. ograničeno nego inače u leksičkome području (usp. Burger; Buhofer; Sialm 1982, 68).

Prema Fleischeru $(1997,205)$ uglavnom razlikujemo sljedeće tipove varijacije:

1) Prva mogućnost sastojala bi se u morfološkoj i djelomično i u sintaktičkoj promjeni pojedinih sastavnica. Te se promjene odnose na broj, rekciju, uporabu člana, umanjenice, vrstu negacije, strukturu glasova i fakultativno obilježje određenih elemenata proširenja koji pripadaju sastavnicama frazema.

2) Druga mogućnost sastojala bi se u izmjeni pojedinih leksičkih sastavnica frazema. $\mathrm{Na}$ taj način nastaju ili frazeološki sinonimi ili antonimi.

3) Treća mogućnost sastoji se u proširenju ili redukciji sastavnica. Ako redukcija dovodi do osamostaljenja skupine sastavnica, posrijedi je frazeološka derivacija. Ako se pak 
osamostaljuje pojedina sastavnica kao riječ, onda je posrijedi defrazeološka derivacija (usp. Fleischer 1997, 207).

Prema Burgeru (2015, 23) i prema Barz (1992, 29), uzimajući u obzir gore spomenute Fleischerove tipove varijacije mogu se dakle razlikovati sljedeći tipovi varijacije (usp. Dräger 2012, 207):

1) varijacija broja sastavnica: od Adama $<i$ Eve $>$

2) varijacija vanjske valencije: praviti zamku komu / za koga

3) topološka varijacija: Janko i Marko / Marko i Janko; kula Babilonska / Babilonska kula

4) morfološka varijacija: biti zabludjela ovca (ovčica); baciti / bacati bisere (biserje) pred svinje

5) gramatička varijacija: doći komu do ruke / do ruku

6) leksička varijacija: dolina suza (plača).

U posljednjim godinama proširilo se uvjerenje da su frazemi u puno većoj mjeri podložni varijaciji nego što se to ranije mislilo. A to vrijedi poglavito za spontani govorni jezik. Istraživanja pokazuju da postoje značajni odmaci od frazema navedenih u kanonskome obliku u rječnicima (usp. Burger 2015, 24). ${ }^{65}$ Varijante su u pravilu alternativnoga karaktera i uglavnom ne mijenjaju značenje frazema. U nekim slučajevima ipak se može utjecati na konotaciju stilske razine već prema konotaciji leksema u slobodnoj uporabi (usp. Palm 1997, 72), primjerice: oprati / prati (umiti) ruke (kao Pilat).

Slijedeći uvriježene podjele $\mathrm{u}$ frazeološkim istraživanjima na hrvatskome jeziku u našoj raščlambi inačice ćemo podijeliti na fonetske, tvorbene, sintaktičke, leksičke, leksičkokvantitativne te ćemo obraditi i slučaj kombinacije više vrsta inačica unutar jednoga frazema (usp. Fink-Arsovski 2002; Vidović Bolt 2011, 36; Kovačević 2012, 83 ${ }^{66}$ ).

\footnotetext{
${ }^{65}$ U spontanome govornom jeziku nije lako razlikovati varijante od pogrješaka i omaški (usp. Bugrer; Buhofer; Sialm 1982, 192). Burger $(2015,25)$ pogrješkama naziva „odmake od kodificirane (gramatičke i leksičke) norme koji se ne poduzimaju s određenom stilskom nakanom“. Međutim, on drži da omaške u govoru ili pri pisanju ,u strukturnome smislu također valja držati pogrješkama. Mnoge frazeološke pogrješke u širemu smislu valja promatrati kao omaške u govoru i pri pisanju jer do pogrješaka dolazi zbog interferencije s drugom frazeološkom i nefrazeološkom konstrukcijom“ (isto).

${ }^{66}$ Budimir $(2020,114)$ govori o fonološkome, morfološkome, tvorbenome, sintatktičkome i leksičkome tipu frazemskih inačica.
} 


\subsection{Fonetske inačice}

Fonetske inačice nastaju tako da dolazi do varijacija u fonetskome sastavu frazema. Među talijanskim frazemima nismo naišli na fonetske inačice. ${ }^{67}$

Među hrvatskim frazemima biblijskoga podrijetla naišli smo da sljedeći frazemi imaju fonetsku inačicu:

slati koga od Heroda (Iruda, Poncija) do Pilata $;{ }^{68}$ mudar kao Salamun (Solomun); salamonsko (salamunsko, solomunsko) rješenje (presuda). ${ }^{69}$

\subsection{Tvorbene inačice}

Tvorbene inačice nastaju različitom tvorbom frazemskih sastavnica istoga korijena, iste vrste riječi i istoga primarnog značenja (usp. Vidović Bolt 2011, 36).

U korpusu biblijskih frazema naišli smo na sljedeće tvorbene inačice:

U talijanskome:

- Imenične: essere una pecora (pecorella) smarrita.

U hrvatskome:

- Imenične: baciti / bacati bisere (biserje) pred svinje

- Glagolske: čitati (očitati) komu levite

- Sinsemantične riječi: ni (niti) za jotu.

\footnotetext{
${ }^{67}$ Premda nisu potvrđene u našemu korpusu, fonetske inačice zacijelo postoje. Frazem portare (porgere, offrire) il ramo d'olivo ima fonetsku inačicu portare (porgere, offrire) il ramo d'ulivo. Stoga mnogi kritiziraju frazeološke rječnike i zahtijevaju drukčiji pristup varijantnosti.

${ }^{68}$ Ovaj frazem pojavljuje se u popisu frazema s dvjema inačicama. Posebice smo ga istaknuli u ovome popisu jer je malen broj frazema s fonetskim inačicama.

${ }^{69}$ I ovaj je frazem istaknut zbog istoga razloga.
} 


\subsection{Sintaktičke inačice}

Do varijacija dolazi i na sintaktičkoj razini bilo da se rabi ili ne rabi neki veznik, da se imenica rabi u nekome drugom padežu i s nekim drugim prijedlogom. Pod sintaktičkim inačicama navode se „frazemi s različitim redom riječi kao i oni koji nastaju uporabom različitih padežno-prijedložnih sveza“ (Budimir 2020, 115).

U talijanskome:

- essere (come) il diavolo e l'acqua santa; giudizio di Salomone (salomonico).

U hrvatskome:

- Brat u Kristu (po Kristu); kula Babilonska (Babilonska kula); biti lukav kao zmija (poput zmije); star kao Metuzalem (metuzalemski star).

\subsection{Leksičke inačice}

Leksičke inačice nastaju zamjenom jednoga leksema nekim drugim leksemom. U pravilu je riječ o leksemima „koji pripadaju istoj vrsti riječi iako to nije pravilo jer je moguća zamjena i leksemom koji nije ista vrsta riječi“ (Vidović Bolt 2011, 37). Posrijedi je „,zamjena jedne frazemske sastavnice (imenice ili glagola) istoga, slična ili suprotna značenja, pri čemu je dubinska struktura frazema ostala nepromijenjena“ (Budimir 2020, 116).

Talijanske frazeme biblijskoga podrijetla prema vrsti riječi podijelili smo na imenične, pridjevske i glagolske.

U talijanskome:

- Imenični: essere una Babele (Babilonia); voce (il richiamo) del sangue; brutto come un demonio (come il diavolo); dare a intendere che Cristo è morto di sonno (di freddo); segno (marchio) di Caino; stirpe (razza, progenie, figli) d'Adamo; tempo (periodo) di vacche grasse (magre).

- Glagolski: dare (gettare) la croce addosso a qualcuno; essere (stare) in croce; essere (sentirsi) come Davide contro Golia; gettare (dare) le perle ai porci; essere (trovarsi) nella fossa dei leoni; portare (porgere, offrire) il ramo d'olivo; riportare (ricondurre) 
qualcuno all'ovile; chiudersi (vivere) in una torre d'avorio; venire (discendere) dalla costola d'Adamo; seminare (mettere) zizzania.

- Pridjevni: essere in costume adamitico (evitico).

U hrvatskome:

- Imenični: premještati brda (planine); biti div (kolos) na glinenim nogama; dolina suza (plača); biti kao janje (ovca) među vukovima; biti žrtveni jarac (žrtveno janje); Kajinov znak (žig); sedam debelih (mršavih, gladnih) krava (godina); pala je komu koprena (mrena, veo) s očiju; vječno prokletstvo (vječne muke); Judine škude (pare).

- Glagolski: biti primljen (otići) u krilo Abrahamovo; biti (naći se) u Babilonu; iščeznuti (nestati) s lica zemlje; nositi (imati) svoj križ; razapeti / razapinjati (pribiti / pribijati) na križ koga.

- Pridjevni: biti u Adamovu (Evinu) kostimu; osobna (naša) Biblija $;^{70}$ biti okrečen (obijeljen) grob; zagrliti vlastiti (svoj) križ; ${ }^{71}$ razmetni (rasipni, izgubljeni, bludni) sin.

\subsection{Leksičko-kvantitativne inačice}

Neke sastavnice frazema moguće je izostaviti, a da to ne utječe na značenje frazema.

U korpusu talijanskoga:

- Aspettare <che piova > la manna dal cielo; con tutti i crismi $<$ e sacrismi $>$; abbracciare la <propria> croce; portare la <propria> croce; parere il Giorno del Giudizio $<$ Universale>; lavarsi le mani <come Pilato>; <fare> come Dio comanda; la maddalena $<$ pentita $>$; occhio per occhio, $<$ dente per dente $>-<$ occhio per occhio $>$, dente per dente; fare <come> san Pietro; $i<q u a t t r o>$ cavalieri dell'Apocalisse; $<$ niente di nuovo $>$ sotto il sole; gridar vendetta $<$ al cospetto di Dio $>$.

U korpusu hrvatskih frazema biblijskoga podrijetla zabilježeni su sljedeći frazemi bez promjene značenja:

\footnotetext{
${ }^{70} \mathrm{U}$ ovome slučaju pridjev je zamijenjen posvojnom zamjenicom.

${ }^{71} \mathrm{U}$ ovome slučaju povratno-posvojna zamjenica zamijenjena je pridjevom.
} 
- $\quad<$ početi> od Adama <i Eve>; <to je> kao amen; dok je Bog <još> po zemlji hodao; dati caru carevo, <a Bogu Božje>; biti Juda <Iškariotski>; čekati <da padne mana $>$ manu s neba; (Ne) pada (padne) komu što <kao mana>s neba; <biti> raj zemaljski; oko za oko, <zub za zub> - <oko za oko>, zub za zub;<vuk> u janjećoj koži; tresti se kao trska $<$ na vjetru $>$; <uraditi $>$ kako Bog zapovijeda.

\subsection{Kombinacija više vrsta inačica unutar jednoga frazema}

Postoji manji broj frazema biblijskoga podrijetla u kojima se pojavljuje više varijantnih sastavnica. Mogu biti posrijedi varijacije iste vrste, s različitim podtipovima ili kombinacije različitih vrsta inačica.

U korpusu talijanskih frazema biblijskoga podrijetla potvrđeni su sljedeći frazemi ${ }^{72}$ :

a) tri frazema s leksičkom i sintaktičkom inačicom: venire dal grembo di Dio (essere nel grembo di Dio); essere un cireneo (fare il cireneo); avere il diavolo in corpo (per capello)

b) jedan frazem s dvjema leksičkim inačicama (glagolskoga i imeničnoga podtipa): (essere) (vecchio) come l'arca di Noè

c) jedan frazem s leksičko-kvantitativnom i tvorbenom inačicom: (essere) un'ira di Dio (d'Iddio)

d) jedan frazem s leksičkom i leksičko-kvantitativnom inačicom: mettere la fiaccola sotto il moggio; nascondere (nascondersi) sotto il moggio

e) jedan frazem s dvjema leksičko-kvantitativnim inačicama i leksičkom inačicom: essere un Eden-giardino dell' Eden - paradiso terrestre

f) jedan frazem s dvjema leksičko-kvantitativnim inačicama: (essere) la voce (di uno che grida) nel deserto

g) jedan frazem s trima leksičkim i jednom leksičko-kvantitativnom inačicom: restare (lasciare) di sale; essere (sembrare) una statua di sale

${ }^{72}$ Radi preglednosti u navođenju primjera za kombinaciju više inačica, sve su inačice navođene u oblim zagradama. Leksičko-kvantitativne nisu posebno navođene u šiljastima. 
h) dva frazema s leksičkom, leksičko-kvantitativnom i sintaktičkom inačicom: essere un Giuda - fare la parte di Giuda; essere (mite come) un agnello (fare l'agnello)

i) jedan frazem s dvjema leksičko-kvantitativnim inačicama, jednom leksičkom i sintaktičkom: (bere)l'amaro calice (bere il calice d'amarezza)

j) jedan frazem s trima leksičkim inačicama i jednom sintaktičkom: avere gli anni (l'età) di Matusalemme - essere un Matusalemme; vecchio come Matusalemme.

U korpusu hrvatskih frazema biblijskoga podrijetla naišli smo na sljedeće frazeme $\mathrm{s}$ kombinacijom više inačica:

a) tri frazema s dvjema leksičkim varijantama (glagolskoga ili glagolskoga i imeničnoga podtipa): ostaviti (pustiti) mrtve da pokapaju (sahranjuju) mrtve; vratiti/vraćati (staviti / stavljati) mač (sablju) u korice; nije komu pala (spala) ni vlas (dlaka) s glave

b) jedan frazem s leksičkom i tvorbenom inačicom: biti izgubljena (zalutala, zabludjela) ovca (ovčica)

c) jedan frazem s leksičko-kvantitativnom i sintaktičkom inačicom: jahači Apokalipse (četiri jahača Apokalipse)

d) dva frazema s fonetskom i leksičkom inačicom: slati koga od Heroda (Iruda, Poncija) do Pilata; salamonsko (salamunsko, solomunsko) rješenje (presuda)

e) jedan frazem s leksičkim inačicama i promjenom slijeda sastavnica (sintaktička inačica): odijeliti (odvojiti) kukolj od pšenice - razdvojiti (odvojiti, razdijeliti) žito od kukolja

f) jedan frazem s leksičkom i leksičko kvantitativnom inačicom: oprati / prati (umiti) ruke (kao Pilat)

g) jedan frazem s leksičkom i dvjema leksičko-kvantitativnim inačicama: (Ne) zna ljevica što (mi) čini (radi) desnica

h) dva frazema sa sintaktičkom i leksičko-kvantitativnom inačicom: (biti) čija slika $i$ prilika (na svoju sliku i priliku); živjeti u raju zemaljskome (kao u raju) 
i) jedan frazem s dvjema sintaktičkim inačicama (razlike u slijedu sastavnica i u padežnoprijedložnim svezama): raj na zemlji (zemaljski raj; raj zemaljski)

j) jedan frazem $\mathrm{s}$ dvjema leksičko-kvantitativnim inačicama, jednom leksičkom i sintaktičkom: (piti) gorki kalež (piti kalež gorčine)

k) jedan frazem s dvjema leksičkim inačicama (glagolskoga i imeničnoga podtipa) i jednom sintaktičkom i leksičko-kvantitativnom inačicom: Zatvoriti se u kulu od slonove kosti (slonovače) - Živjeti u kuli od slonove kosti.

$\mathrm{Na}$ temelju raščlambe korpusa frazema biblijskoga podrijetla $\mathrm{u}$ talijanskome $\mathrm{i}$ hrvatskome može se ustvrditi da 47 talijanskih frazema $(22,5 \%)$ i 55 hrvatskih frazema $(32,4$ \%) ima barem po jednu inačicu ili čak i kombinaciju dviju ili više inačica istodobno.

Kao što se moglo i očekivati, najmanje su zastupljene fonetske inačice. U talijanskome korpusu nije potvrđena nijedna, što može biti posljedica i određene frazeografske tradicije. U hrvatskome korpusu potvrđena su dva frazema s fonetskim inačicama.

Ni frazemi s tvorbenim inačicama nisu brojni. U talijanskome korpusu potvrđen je samo jedan frazem s inačicom imeničnoga podtipa (zamjena imenice umanjenicom), a u hrvatskome potvrđena su tri primjera s tvorbenim inačicama: po jedan primjer imeničnoga i glagolskoga podtipa i jedan primjer s inačicom sinsemantične riječi.

Najbrojnije su u obama jezicima leksičke inačice, poglavito imenične i glagolske. Uglavnom je posrijedi zamjena jedne frazemske sastavnice istoznačnicom ili bliskoznačnicom, u pravilu iste vrste riječi ili pak leksemom iz istoga semantičkoga polja ili asocijativnoga niza i u jednome slučaju zamjena antonimskim parnjakom. ${ }^{73}$ Kod imeničnoga podtipa imenica kojom se zamjenjuje jedna sastavnica može, ali ne mora biti ni istoga roda ni broja. U talijanskome korpusu potvrđeno je sedam leksičkih inačica imeničnoga i deset glagolskoga tipa te samo jedan primjer inačice pridjevnoga tipa, a u hrvatskome deset frazema s inačicama

\footnotetext{
${ }^{73}$ Budimir $(2020,116)$ osim zamjene antonimskim parnjakom spominje i slučajeve inačica čije sastavnice ne ulaze $\mathrm{u}$ isto semantičko polje ili asocijativni niz, što u korpusu talijanskih i hrvatskih frazema biblijskoga podrijetla nije potvrđeno.
} 
imeničnoga podtipa, pet glagolskoga podtipa te pet frazema s inačicama pridjevnoga podtipa (u dvama slučajevima dolazi do zamjene pridjeva posvojnom zamjenicom).

U obama korpusima više je frazema s leksičko-kvantitativnim inačicama: trinaest $u$ talijanskome i dvanaest u hrvatskome. U obama jezicima fakultativna može biti uporaba veznika, priloga, glagola, imenice, pridjeva, priložne oznake ili čak i dijela frazema (uglavnom kod frazema nastalih od poslovica).

U obama korpusima potvrđen je znatan broj frazema s kombinacijom više inačica, trinaest $\mathrm{u}$ talijanskome $\mathrm{i}$ petnaest $\mathrm{u}$ hrvatskome. Zastupljene su i kombinacije različitih podtipova leksičkih inačica (imeničnoga i glagolskoga podtipa), s dvjema sintaktičkim inačicama, dvjema leksičko-kvantitativnim inačicama, ali i kombinacija leksičke i tvorbene varijacije, leksičke i sintaktičke, leksičke i leksičko-kvantitativne, sintaktičke i leksičkokvantitativne itd. Čak je u nekoliko slučajeva potvrđena kombinacija triju, a u jednome primjeru i četiriju inačica: leksičke inačice imeničnoga podtipa, leksičke inačice glagolskoga podtipa, sintaktičke i leksičko-kvantitativne.

Pri određivanju inačica držimo se dakle frazeografske tradicije i odluka autora rječnika, a kao što je već spomenuto, u novijim se radovima upozorava da je varijantnost puno veća nego što je to zabilježeno u frazeološkim rječnicima, što će svakako biti zadaća onih koji se bave arealnom frazeologijom čije su metode i istraživanja, osobito u romanističkome jezikoslovlju još u povojima.

Može se s velikom vjerojatnošću pretpostaviti da će i frazemi biblijskoga podrijetla u obama jezicima promatrani s povijesnoga i arealnoga stajališta potvrditi puno više inačica ${ }^{74}$ nego što je navedeno $u$ frazeološkim rječnicima obaju jezika - u ovome radu obrađena je varijantnost normativnih primjera, primjera koji su leksikografske jedinice.

\footnotetext{
${ }^{74}$ Dijelimo mišljenje Elisabeth Piirainen (2006) koja upozorava da još ne postoji svijest o tome da frazemi vrijede samo na jednome ograničenom području i da predodžba tradicionalnih frazeoloških istraživanja o homogenome frazeološkom inventaru iznad regionalne razine ne vrijedi poglavito za jezik kao primjerice njemački te dodaje: „Die Dialekte haben deutliche Spuren in der Phraseologie sowohl der Schriftsprache als auch der standardnahen, mündlich gebrauchten Umgangssprachen hinterlassen. Andererseits wird beobachtet, dass bestimmte Phraseologismen in weit größeren Sprachräumen als dem einer Einzelsprache existieren. Phraseologieforschung in europäischen Bezügen und darüber hinaus steht ebenfalls noch am Anfang und verlangt nach sorgfältigen empirischen Erhebungen“"(2006, § 1.).
} 
$\mathrm{S}$ obzirom na to da se $\mathrm{u}$ talijanskome jezikoslovlju počesto naglašava razlika uporabe standardnoga i regionalnoga talijanskog jezika - mnogi govornici, čak i jezikoslovci tvrde da govore regionalni talijanski - onda će to itekako vrijediti i za frazeologiju.

Kako u obama jezicima nedostaju iscrpnija istraživanja varijantnosti te osobito rječnici frazema biblijskoga podrijetla ${ }^{75} \mathrm{u}$ narječjima, dijalektima te $\mathrm{u}$ lokalnim govorima talijanskoga i hrvatskoga jezika i znanstveno utemeljen pristup varijaciji u duhu novih spoznaja historijske i arealne frazeologije, o ovome će se moći još štošta reći. ${ }^{76}$

\footnotetext{
${ }^{75}$ Korpusi frazema biblijskoga podrijetla za ovo istraživanje sastavljeni su od primjera ekscerpiranih također i iz tiskanih i digitalnih rječnika rađenih na temelju podataka iz velikih mrežnih korpusa. No još uvijek postoje brojna nesuglasja i nesnalaženja kada je riječ o leksikografskoj obradbi frazema i određivanju kanonskoga oblika. Očito će biti potrebno dosta vremena da se ti problemi riješe.

${ }^{76} \mathrm{U}$ supostavnoj raščlambi frazema biblijskoga podrijetla valjalo bi svakako usporediti frazeme s onomastičkim, antroponimskim i toponimskim sastavnicama. Međutim, tomu se može posvetiti zasebno istraživanje i stoga se u okviru ovoga rada time ne kanimo baviti.
} 


\section{SEMANTIČKA RAŠČLAMBA TALIJANSKIH I HRVATSKIH FRAZEMA BIBLIJSKOGA PODRIJETLA}

Semantičkoj raščlambi frazema može se pristupiti s različnih stajališta i svaki pristup rasvjetljava vrlo složenu semantičku strukturu frazema. Značenje je frazema usuprot značenju riječi dugo već predmetom zanimanja frazeologa i drugih jezikoslovaca. S time u svezi postoje i različite podjele u semantičkome pristupu frazemu.

Zanemarivanje semantičke komponente dovelo je do „opisa frazeoloških jedinica kao jezičnih konfiguracija protivnih normi u kojima se krše jezična pravila. Isključiva usredotočenost na gramatička stajališta nije pak mogla objasniti nepravilnosti koje obilježavaju frazem“ (Chrissou 2000, 19).

Riječ ili leksem kao slobodni oblik (za razliku od neslobodnoga u frazemu) „nije samo ime, imenovanje ili nominacija, nego i logični okvir, klasa s obilježjima ili elementima, kao primjerice materijal, oblik i boja“ (Palm 1997, 7). Riječ ili leksem može se slobodno kombinirati s drugim jezičnim elementima i to u horizontalnome smjeru, držeći se pri tome sintagmatskoga gramatičkog povezivanja. Za razliku od toga „kod vezanoga značenja elementi zajednički tvore značenje koje se na sintagmatskoj razini ne može slobodno kombinirati, a na paradigmatskoj razini ne može slobodno supstituirati““ (isto).

Stoga „,vezano ili zajedničko značenje ne može se izvesti aditivno iz zbroja značenjā, ono znači više i nešto drugo“ (Palm 1997, 8).

Sama činjenica da su frazemi višerječne sveze dovodi do sintagmatske asimetrije (usp. Chrissou 2000, 21). U slučaju paradigmatske asimetrije riječ je o stvaranju asocijativnih odnosa između označavanja postojećega predmeta i predmeta koji valja iznova imenovati pri čemu „odnos ne iznosi 1:1, nego poprima asimetrični oblik koji dovodi do semantičke transpozicije, odnosno idiomatičnosti“" (Chrissou 2000, 22).

U literaturi na hrvatskome uglavnom su u središtu zanimanja semantičke raščlambe „frazeologizacija, stupanj desemantiziranosti frazema, njihovo značenje, motiviranost i slikovitost“" (Vidović Bolt 2011, 41). Tako da se prema stupnju desemantiziranosti frazeme dijeli na potpuno ili djelomično desemantizirane. 
Mnoge sveze riječi doduše pokazuju stabilnu strukturu, ali su primjerice kao kolokacije posvema neupadljive. Druge pak sveze riječi pokazuju semantičke značajke koje se mogu iskoristiti u jezičnoj uporabi (usp. Burger 2015, 79).

U poglavlju posvećenome idiomatičnosti frazema, govoreći o semantičkoj idiomatičnosti frazeme smo prema Burgeru $(2015,27)$ podijelili na idiomatske, djelomično idiomatske i neidiomatske frazeme. Premda je ta trodijelna razdioba korisna, ipak je valja dalje produbiti jer je idiomatičnost kategorija sa stupnjevitim prijelazima.

S pitanjem idiomatičnosti usko je povezano i pitanje ,imaju li frazemi drukčije značenje s obzirom na riječi i trebaju li oni, leksikografski gledano, posebnu vrstu objašnjenja značenja“ (Burger 2015, 61).

Kao što smo već spominjali Burger $(2015,13$ - 14) uvodi pojam „slobodnoga“ značenja (njem. freie Bedeutung) u odnosu na „frazeološko“ (njem. phraseologische Bedeutung). Međutim, i sam pojam „slobodno“ značenje pokazuje se problematičnim jer pretpostavlja da se može povući crta između sveza riječi koje su nastale na temelju regularnih procesa semantike i sintakse i drugih sveza koje se može ubrojiti u skupinu više ili manje iregularnih frazeoloških sveza (usp. Burger 2015, 61) i stoga je „slobodno značenje u određenoj mjeri fikcija koja služi pojašnjavanju specifičnosti frazeološkoga značenja“ (isto).

\subsection{Načini čitanja frazema}

Postoje frazemi koji barem mogu imati dvostruku značenjsku strukturu. S jedne strane mogu se razumjeti u svojemu frazeološkom značenju, a s druge kao slobodne sveze riječi. Prema Burgeru $(2015,63)$ cijelo područje frazeologije „,može se podijeliti prema kriteriju ima li neki izraz jedno ili dva čitanja“.

U skladu s time frazeme prema kriteriju načina čitanja možemo podijeliti na:
a) samo jedan način čitanja
b) dva čitanja koja se jedno prema drugome odnose disjunktivno
c) dva čitanja koja se mogu istodobno ostvarivati
d) mješoviti tip. 


\subsubsection{Samo jedno čitanje}

Za frazeme koji imaju samo jedan način čitanja tipično je da su na jednoj strani posrijedi izrazi koji nisu idiomatski kao primjerice kolokacije, a na drugoj strani izrazi s osobito jasnom idiomatičnošću, kao primjerice frazemi s frazeološki vezanim ${ }^{77}$ sastavnicama. To bi bili dakle frazemi pri vrhu i pri dnu ljestvice idiomatičnosti (usp. Burger 2015, 64).

Primjerice frazemi

- u tal.: mandare qualcuno da Erode a Pilato; essere come il gallo che cantò a san Pietro; fare repulisti

- $\quad$ u hrv.: u nebo vapijući grijeh; Sin Čovječji; vuk u janjećoj koži

pripadaju skupini frazema koje mogu imati samo jedno čitanje i to frazeološko. Budući da nismo u popis ekscerpiranih frazema uključili mnoge rutinske formule koje mogu, ali ne moraju biti biblijskoga podrijetla, samo frazemi s jasnom idiomatičnošću pripadaju toj skupini. Kako ni u talijanskome ni u hrvatskome korpusu nema mnogo frazema s frezeološki vezanim sastavnicima, arhaizmima ili nekrotizmima, broj frazema s jednim čitanjem nije velik i toj skupini pripadaju ostali frazemi koji su posvema idiomatski (idiomi).

Primjerice particip glagola repellere glasi repulisti. Pojavljuje se u psalmu 42,2 „Quare me repulisti“", a taj psalam molio se na početku tradicionalnoga rimskog obreda. Puk u Italiji povezao ga je s glagolom pulire i oblik repulisti pojavljuje se samo u frazemu fare repulisti $\mathrm{u}$ značenju 'odnijeti sve s nekoga mjesta' ili 'sve pojesti'. Stoga taj frazem s frazeološki vezanom sastavnicom može imati samo jedno čitanje.

Skupini frazema s jednim načinom čitanja dodali bismo i nekoliko frazema biblijskoga podrijetla na latinskome koji se rabe u talijanskome jeziku.

\subsubsection{Dva čitanja koja se jedno prema drugome odnose disjunktivno}

Pod pojmom „disjunktivno“ misli se da se oba čitanja ne mogu pojaviti u istome surječju ili komunikacijskoj situaciji. U tu skupinu mogu se ubrojiti različni tipovi frazema, primjerice frazemi čija čitanja nemaju nikakve veze jedno s drugim, dakle homonimni su, a s druge strane

\footnotetext{
${ }^{77}$ Za pojašnjenje pojma frazeološki vezane sastavnice usp. Konecny 2014.
} 
frazemi u kojima se može stvoriti metaforična povezanost. Taj tip idioma naziva se metaforičnim idiomima (usp. Burger 2015, 65).

Mnoštvo je primjera u obama korpusima koja imaju dva čitanja, a ta se dva čitanja mogu pojaviti u različnim surječjima, primjerice

- u tal: essere nella fossa dei leoni < dosl. biti u lavljoj jami>; portare il ramo d'olivo $<$ dosl. nositi maslinovu granu>; pagare nella valle di Giosafat $<$ dosl. platiti u dolini Jozafat $>$; aspettare il corvo $<$ dosl. čekati gavrana $>$.

Uz frazeološko značenje ti frazemi mogu imati i slobodno značenje. Neki se istraživač uistinu može naći u lavljoj jami, na Cvjetnicu se može nositi maslinova grančica, a u dolini Jozafat može se tijekom posjeta Svetoj Zemlji primjerice posjetiti nešto, objedovati, netko može čekati pticu gavrana.

- u hrv.: biti (naći se) u Babilonu; osobna (naša) Biblija; nositi svoj križ; iščupati žito s kukoljem; vratiti / vraćati (staviti / stavljati) mač (sablju) u korice; biti okrečen (obijeljen) grob itd.

Uz frazeološko svi ti primjeri uistinu mogu imati u određenome surječju i slobodno značenje. Zahvaljujući dvama mogućim čitanjima mnogih frazema nerijetko se rabe u reklamama, sloganima, krilaticima, naslovima članaka ili knjiga.

\subsubsection{Dva čitanja koja se ostvaruju, odnosno mogu ostvarivati istodobno}

Kod ovoga tipa izraza uglavnom su posrijedi geste, dakle „neverbalno ponašanje“ koje se uistinu može ostvariti, a s druge strane njihova jezična kodifikacija. Za frazeme koji pokazuju takav tip dvoslojne strukture, naslanjajući se na psihološku terminologiju na području kinezike, stvoren je pojam kinegram. Važno je napomenuti da već u stvarnosti izvršena gesta, odnosno gesta koja se može izvršiti ima kulturalno kodificirano značenje (usp. Burger 2015, 65). Pri tome valja razlikovati sljedeće semiotičke razine:

1. faktično ponašanje (,formu“ neverbalnoga ponašanja)

2. konvencionalno značenje toga ponašanja (,značenje“ neverbalnoga ponašanja) 
3. jezično očitovanje (,formu“ očitovanja)

4. dvorazinsko „značenje“ jezičnoga izričaja:

a) označavanje faktičnoga ponašanja

b) označavanje značenja ponašanja (usp. Burger 2015, 65 - 66).

U talijanskome korpusu zabilježeno je nekoliko primjera koji ispunjaju kriterije toga načina čitanja: cospargersi il capo di cenere, toccare con mano.

U hrvatskome su tri primjera: okrenuti drugi obraz, posuti se pepelom i cjelivati komu rane.

\subsubsection{Mješoviti tip}

Ovome tipu pripada skupina djelomično idiomatskih frazema. U mnogim slučajevima kod idiomatske sastavnice zamjetan je metaforični odnos između frazeološkoga i doslovnoga čitanja. Stoga toj skupini pripadaju ponajprije komparativni frazemi (usp. Burger 2015, 66):

- u tal: mite come un agnello; brutto come un demonio; essere come i soldati del re Erode; forte come Sansone; vecchio come l'arca di Nò̀

- u hrv.: krotak kao janje; ležati kao Lazar; živjeti kao u raju; jak kao Samson; star kao Metuzalem.

Na temelju raščlambe može se zaključiti da su frazemi biblijskoga podrijetla u obama jezicima heterogeni. Zastupljeni su različni podtipovi frazema, a time i sva četiri načina čitanja. S obzirom na to da nisu uvrštene u korpus mnoge rutinske formule i kolokacije, skupina frazema s jednim načinom čitanja svela se uglavnom na potpuno idiomatske frazeme, posebice frazeme $\mathrm{s}$ frazeološki vezanim sastavnicama u obama jezicima te nekoliko frazema na latinskome koji postoje u korpusu talijanskih frazema. Broj frazema koji imaju dva čitanja koja se mogu ostvarivati istodobno također nije velik u hrvatskome. Riječ je o kinegramima biblijskoga 
podrijetla. Većina frazema pripada ili skupini frazema koji imaju dva čitanja koja se jedno prema drugome odnose disjunktivno ili mješovitomu tipu koji uglavnom čine komparativni frazemi.

\subsection{Motiviranost frazema}

Pojam motiviranosti u frazeološkoj je literaturi duže vrijeme dovodio do mnogih nejasnoća i zbunjenosti. No na temelju svega dosad spomenutog jasno je da su idiomatičnost i motiviranost komplementarni pojmovi. Što je frazem većma idiomatski, time je istodobno manje motiviran. Prema Burgeru $(2015,67)$ pod motiviranošću općenito se podrazumijeva da je ,značenje frazema razumljivo iz slobodnoga značenja sveze riječi ili iz značenjā sastavnica“‘. To na znakovno-teorijskoj razini odgovara ,pojmu 'sekundarne motiviranosti' kod Ferdinanda de Saussurea i time stoji usuprot 'arbitrarnosti'. U tome je smislu 'motiviranost' suprotstavljen pojam semantičkoj 'idiomatičnosti'“‘ (isto).

\subsubsection{Motiviranost na temelju značenja i mogućnost motiviranja}

Od motiviranosti na temelju značenja Dobrovol'ski / Piirainen razlikuju motiviranost na temelju oblika: „Kod motiviranosti na temelju oblika posrijedi je u većini slučajeva dodatna motivacija preko strukture u odnosu na semantičku transparentnost cijeloga idioma, a to osobito u slučaju frazeoloških usporedaba. Premda se ne zna kakav je Schneekönig, Honigkuchenpferd ili Strandhaubitze [...], idiomi s ovim sastavnicama djeluju kao djelomično motivirani (1997, 107 - 108 prema Chrissou 2000, 23).

Ako je pak motiviranost samo komplementaran pojam idiomatičnosti, ne bi bio potreban i sve bi se rješavalo tipologijom idiomatičnosti.

No uglavnom se misli i na neke druge vidove koje Burger dijeli na temelju pojma „razumljiv“ (njem. verstehbar) (usp. Burger 2015, 67):

1. Neki frazem ,razumljiv“ je određenim govornicima jer im je slikovitost jasna ili jer stvaraju asocijacije s obzirom na pojedinačne sastavnice (= psiholingvistički vid).

2. Frazem je razumljiv u tekstu zahvaljujući kontekstu. 
3. Metaforično je prepoznatljiv (= tekstnolingvistički vid).

4. Frazem je određenim govornicima „razumljiv“ jer poznaju njegovu etimologiju i njegovo historijsko podrijetlo (= povijesni vid).

5. Sa semantičkoga stajališta riječ je o udjelu koji ima doslovno značenje cijele sveze riječi ili jedne sastavnice u ostvarivanju i time i „razumljivosti“ frazeološkoga značenja. Burger one riječi i sveze koje u svojemu slobodnom značenju sudjeluju u stvaranju frazeološkoga značenja, naziva „semantičkom bazom“ frazema (usp. Burger 2015, 67).

Kada je riječ o semantičkim odnosima, moraju biti posrijedi „odnosi koje valja pripisati sustavu jezika i koje je prosječan izvorni govornik kadar vazda razumjeti i koji ne igraju ulogu samo pod individualnim i kontekstualnim uvjetima“" $(2015,68)$.

U skladu s time frazemi su motivirani ako imaju semantičku bazu. U slučajevima 1 do 3 može se govoriti o mogućnosti motiviranja (usp. Burger 2015, 68). ${ }^{78}$

Ako motiviranost i mogućnost motiviranja promatramo sa stajališta međujezične usporedbe, s obzirom na frazeme biblijskoga podrijetla možemo reći da su primjerice govornicima hrvatskoga jezika mnogi frazemi u talijanskome razumljivi jer oni poznaju jednakovrijednice u hrvatskome ili frazeme sličnoga značenja, odnosno biblijske tekstove $u$ kojima se spominju ili iz kojih potječu, primjerice:

bacio di Giuda, figliol prodigo, vecchio come Matusalemme, forte come Sansone, Torre di Babele.

U hrvatskome postoje jednakovrijednice: Judin poljubac, star kao Metuzalem, snažan kao Samson, kula Bablilonska, razmetni (rasipni, izgubljeni, bludni) sin.

Isto tako razumljivi su im frazemi koji nisu posvemašnje jednakovrijednice, ali je značenje jednako ili vrlo slično:

\footnotetext{
78 Burger rabi pojam motivirerbar i Motivierbarkeit: 'koji se može motivirati', za razliku od motiviert i
} Motiviertheit: 'motiviran' i 'motiviranost'. 
avere gli anni di Matusalemme < dosl. imati Metuzalemove godine>; avere la pazienza di Giobbe < dosl. imati Jobovo strpljenje> usuprot hrvatskim frazemima: star kao Metuzalem; strpljiv kao Job.

Zahvaljujući poznavanju biblijskih tekstova - premda se pretpostavlja malo dublje poznavanje, razumljivi su i frazemi koji ne postoje u hrvatskome kao primjerice:

fare il casto Giuseppe < dosl. biti čedni Josip >; fare la casta Susanna $<$ dosl. biti čedna Suzana>.

Svima je poznat lik čednoga Josipa, zaručnika Marijina i Isusova skrbnika. Manje je poznat, no ipak posvema jasan kao dio frazema lik Suzane, krjeposne žene koja se spominje u Knjizi Danijelovoj (XIII).

Osim toga, razumljivi su i komparativni frazemi s onimskim sastavnicama koji ne postoje u hrvatskome:

essere atteso come il Messia <dosl. biti čekan kao Mesija>; essere vecchio come l'arca di Noè < dosl. biti star kao Noina korablja $>$.

Svima koji iole poznaju svetopisamske tekstove, jasno je da je Izrael dugo čekao Mesiju i da je Noina korablja izgrađena uoči općega potopa te je stoga „pretpotopna“ 79 i većini govornika značenje je frazema posvema jasno.

Burger $(2015,68)$ k tome napominje da su djelomični idiomi djelomično motivirani. Osobito nam u slučaju komparativnih frazema i leksičkih binoma pomaže intuitivno znanje da dokučimo značenje cijeloga frazema jer su posrijedi pojačavanje i intenziviranje temeljnoga značenja, čak i bez poznavanja riječi ili osoba kao u slučaju frazema biblijskoga podrijetla.

Primjerice, komparativni frazemi u talijanskome:

essere nero come l'anima di Giuda; avere gli anni di Nò̀

te leksički binomi:

cominciare da Adamo ed Eva

\footnotetext{
${ }^{79} \mathrm{U}$ hrvatskome se govornom jeziku često frazem biti pretpotopan (pretpotopna) podrugljivo rabi za označavanje iznimno starih osoba ili stvari.
} 
ili komparativni frazemi u hrvatskome:

tresti se kao trska <na vjetru>; kao truba jerihonska; lukav kao zmija (lukav poput zmije)

ili leksički binomi:

vezati i driješiti

vrijede kao djelomično motivirani ako bismo izostavili povijesni vid i poznavanje etimologije tih frazema u slučaju talijanskih frazema s onimskim sastavnicama, a zahvaljujući općemu ljudskom iskustvu i razumijevanje navedenih frazema na hrvatskome.

Neki pojmovi poznati su iz Biblije, no nije posve jasno njihovo značenje kada su dijelom određenoga frazema jer bi mogli značiti više stvari istodobno, primjerice frazemi $u$ talijanskome:

vecchio Adamo < dosl. stari Adam>; Chiamate Erode! < dosl. Pozovite Heroda! >; la maddalena <pentita $><$ dosl. Magdalena < pokajnica $>>$.

Premda je Adam - prvi čovjek, biblijski lik koji je duboko ušao i u svjetovnu kulturu, to je značenje nejasno jer bi se moglo povezati s iznimnom starošću, a ne samo s čovjekom koji nije očišćen od neke krivice. U evanđeljima se osim Heroda Velikoga ${ }^{80}$ judejskoga kralja spominje i Herod Antipa, ${ }^{81}$ palestinski tetrarh. Herod Veliki naredio je pokolj dojenčadi u Betlehemu, a Herod Antipa, drugi sin Heroda Velikoga koji je sudjelovao u suđenju Isusu Kristu pojavljuje se u frazemu - u tal.: mandare qualcuno da Erode a Pilato i u hrv.: slati koga od Heroda (Iruda) do Pilata, tako da bi značenje moglo biti dvojako da u hrvatskome ne postoji jednakovrijednica.

Čak su neodređeni i neki komparativni frazemi kao primjerice: essere come il gallo che cantò a san Pietro < dosl. biti kao pijetao koji zapjeva svetomu Petru>. Jasno je jedino prema surječju ako se govori o piletini odnosno o pijetlu koji je vrlo star i čije je meso žilavo.

Nemotivirani su prema Burgeru $(2015,68)$ idiomi s dvama čitanjima koji imaju homonimna značenja.

Chrissou (2000, 48) napominje da ,semantički spektar između motiviranosti i nemotiviranosti u koji se frazemi daju uvrstiti pokazuje dinamičke procese u frazeologiji“, a

\footnotetext{
${ }^{80}$ Usp. $<$ https://www.enciklopedija.hr/natuknica.aspx?ID=25193> (7.7.2020.).

${ }^{81}$ Usp. $<$ https://www.enciklopedija.hr/natuknica.aspx?id=25186> (7.7.2020.).
} 
prema Hessky $(1987,36)$ u svakome sinkronijskom presjeku jezika ,postoje frazemi na svakome stupnju motiviranosti odnosno nemotiviranosti“. Pri tome valja uzeti u obzir da ne ostaju zanavijek ,'prikovanima', nego se poradi jezične dinamike, pod utjecajem brojnih heterogenih sila nalaze u gibanju k sljedećoj razini““ (isto). Stoga Chrissou $(2000,49)$ zaključuje da je moguće da „die Motiviertheit bei einer motivierten phraseologischen Einheit allmählich abschwächt, bis sie zur Teilmotiviertheit und später zur Unmotiviertheit wird. Dieser Prozess kann aber auch gegensätzlich verlaufen. Eine teilmotivierte bzw. unmotivierte Verbindung kann sich remotivieren“.

Da zaključimo: među biblijskim frazemima u obama jezicima postoji određeni broj frazema koje možemo držati motiviranima jer ih je prosječan govornik uvijek kadar razumjeti. U svezi s frazemima biblijskoga podrijetla pretpostavlja se da prosječan govornik ima barem prosječno znanje o Bibliji.

Veliki broj frazema biblijskoga podrijetla pripada skupini onih frazema koji imaju mogućnost motiviranja (njem. motivierbar) jer im je slikovitost jasna ili stvaraju asocijacije i razumiju se zahvaljujući surječju u kojemu se rabe ili jer su metaforično prepoznatljivi. Osobito u slučaju djelomičnih idioma čiji jedan dio zadržava slobodno značenje možemo govoriti o djelomičnoj motiviranosti. To navlastito vrijedi za komparativne frazeme i leksičke binome gdje nam pomaže intuitivno znanje. U slučaju frazema s dvama načinima čitanja koji su homonimi ne možemo govoriti o motiviranosti.

Iz međujezične perspektive motiviranosti i mogućnosti motiviranja pristupa se na drukčiji način. Međutim, postojanje frazema koji imaju ekvivalente ili djelomične ekvivalente u obama jezicima olakšava razumijevanje frazema iz drugoga jezika, a tomu, konkretno u slučaju frazema biblijskoga podrijetla u talijanskome i hrvatskome jeziku, bitno pridonosi pripadanje rimokatoličkomu svijetu i dugostoljetno celebriranje istoga obreda i čitanje / prevođenje istoga latinskog prijevoda Biblije, Vulgate Jeronima Dalmatinca.

\subsubsection{Remotiviranje ili ambigvitet}

U surječju motiviranosti i mogućnosti motiviranja spominje se i pojam remotiviranja. Drugi autori govore o ambigvitetu (usp. primjerice Donalies 2009, 23). Riječ je o sposobnosti frazema da ostvare „i doslovno i idiomatsko značenje“ (Lapinskas 2013, 77). Prema Burgeru 
$(2015,68)$ posrijedi je „tekstnolingvistička pojavnost da se modifikacijama aktivira doslovna razina frazema, već spomenuti drugi vid motiviranosti““.

Re-motivirati moguće je frazeme koji

a) imaju dva čitanja koja se jedno prema drugome odnose disjunktivno

b) imaju dva čitanja koja se ostvaruju, odnosno mogu ostvarivati istodobno

c) predstavljaju mješoviti tip (usp. Lapinskas 2013, 77). ${ }^{82}$

Prema Burgeru nejasan je i dvosmislen pojam remotiviranja jer nije posrijedi „remotiviranje (tako reći okretanje genetskoga procesa), nego aktivacija gotovo bilo kojih vidova mogućega doslovnog načina čitanja jedne sastavnice ili više njih u frazemu“"(Burger 2015, 69). Stoga on predlaže pojam „motiviranja (za razliku od re-motiviranja) ${ }^{83}$ ili aktualiziranja doslovnoga načina čitanja ili jednoga doslovnog načina čitanja“ (isto).

Upravo ta odlika frazema govornicima omogućuje da ih rabe za jezične igre, izricanje nezadovoljstva, skepse, ironije i sarkazma, ushićenja i pohvale itd.

Remotiviranjem se postižu humoristični učinci te su stoga takvi frazemi pogodni za slogane, krilatice, reklame, predizborne kampanje, upečatljive naslove.

Primjerice, na hrvatski se frazem biblijskoga podrijetla teče med $i$ mlijeko $<$ gdje $>{ }^{84} \mathrm{u}$ značenju 'zemlje blagostanja', što je njegovo frazeološko značenje, može naići u mnogim novinskim tekstovima i primjera je bezbroj, bilo da je riječ o gospodarskoj situaciji u Hrvatskoj, Njemačkoj ili Europskoj Uniji itd. Doslovno je pak značenje toga frazema moguće aktualizirati da uz značenje blagostanja označava uistinu porabu meda i mlijeka u kozmetici i medicini, osobito za zdravu kožu. Tu aktualizaciju doslovnoga značenja imamo primjerice u naslovu članka „Neka po vašoj koži teče med i mlijeko““ ${ }^{85} \mathrm{Uz}$ frazeološko značenje blagostanja i

\footnotetext{
${ }^{82} \mathrm{~S}$ obzirom na podjelu na četiri načina čitanja može se zaključiti da se ne mogu re-motivirati samo frazemi s jednim načinom čitanja, a to je podskupina koju čine ili kolokacije (koje nisu idiomatske) ili potpuno idiomatski frazemi tj. idiomi (usp. § 11.1.).

${ }^{83}$ Burger rabi u njemačkome pojam Motivierung: 'motiviranje', usuprot pojmu Motiviertheit: 'motiviranost' (usp. Burger 2015, 69).

${ }^{84}$ „Frazem teče med i mlijeko biblijskoga je podrijetla, nastao prema izrazu 'zemlja u kojoj teče med i mlijeko', a koji je potvrđen u mnogim biblijskim citatima - njime se opisuje zemlja blagostanja Kanaan, koju je Bog namijenio svome Izabranom narodu. Upravo su med i mlijeko simboli toga blagostanja jer je riječ o dvjema vrlo dragocjenim namirnicama, ali ne uvijek dostupnima u prehrani Izraelaca“" (Opašić; Čunović; Fumić 2013, 99).

${ }^{85}<\mathrm{http}: / /$ ordinacija.vecernji.hr/budi-lijepa/njega-tijela/neka-po-vasoj-kozi-tece-med-i-mlijeko/> (9.7.2020.).
} 
dobrobiti posrijedi je stvarna poraba tih dviju prirodnih tvari koje obiluju hranjivim sastojcima i time pomažu u njezi kože.

Isto vrijedi i za talijanski frazem biblijskoga podrijetla essere (trovarsi) nella fossa dei leoni < dosl. biti (naći se) u lavljoj jazbini, jami> koji ima značenje: 'biti u velikim neprilikama; biti izvrgnut pogibeljima svake vrste'. Leksička inačica toga frazema entrare nella fossa dei leoni rabi se u naslovu novinskoga članka: „Follia allo zoo: entra nudo nella fossa dei leoni. Salvato dagli agenti““, ${ }^{86}$ kada mladić, poradi psihičkih poremećaja nesvjestan, svjesno ulazi u lavlji kavez u jednome zoološkom vrtu. Premda drugi izvori spominju ,gabbia dei leoni“, lavlji kavez, u naslovu se toga članka aludira na sve pogibli koje su pratile mladića koji je zbilja ušao u lavlji kavez u zoološkome vrtu.

Primjera takve vrste ima još podosta i gore spomenuti tip frazema biblijskoga podrijetla koji omogućavaju aktualizaciju doslovnoga načina čitanja ili jednoga doslovnog načina zbog svoje ekspresivnosti vrlo je pogodan za takvu uporabu frazema.

\subsection{Semantička autonomija sastavnica}

U okviru kognitivno - lingvističkoga promatranja idioma (usp. Dobrovol'skij 1995) zamjetna je tendencija da se idiomima ${ }^{87}$ pripisuje veći stupanj prozirnosti ili transparentnosti nego što je to bio slučaj u strukturalistički orijentiranim radovima. Posrijedi je dakle jasan odmak od predodžbe o idiomatskome ,zajedničkom značenju“ i naglašavanje semantičkoga statusa sastavnica frazema uz pregnuće da ih se promatra donekle autonomnima. Ovaj problem tiče se poglavito idioma jer je u slučaju drugih frazeoloških tipova bjelodano da sve ili neke sastavnice imaju samostalnu semantičku ulogu (usp. Burger 2015, 69).

Kako se idiomu ne u cijelosti nego u pojedinim dijelovima pripisuje značenje, govori se o semantičkoj djeljivosti, a s obzirom na nastanak zajedničkoga značenja govori se o kompozicionalnoj semantičkoj strukturi koja stoji usuprot pojmu cjelovite semantičke strukture (usp. Burger 2015, 69).

\footnotetext{
${ }^{86}<$ https://www.ilgiornale.it/news/mondo/follia-zoo-entra-nudo-nella-fossa-dei-leoni-salvato-dagli-ag1262260.html> (10.7.2020.).

${ }^{87}$ Pod pojmom idioma mislimo na Burgerovu definiciju idioma koja je više puta spomenuta u ovome radu.
} 
Ta semantička djeljivost ima različne oblike, a u slučaju frazema biblijskoga podrijetla, ne govoreći o izomorfizmu cijeloga idioma, nego jedne ili pojedinih sastavnica idioma kojima se pripisuje određena mjera semantičke autonomije, valja pripomenuti da te sastavnice i izvan idioma imaju značenje, a to je značenje barem slično značenju kada su dijelom idioma. A to vrijedi općenito za frazeme s riječima koje su elementi kulturnoga simboličkog polja kao boje, životinje itd. (usp. Burger 2015, 70).

Primjerice, talijanski idiom andare in Cafarnao <dosl. ići u Kafarnaum> u značenju 'perdersi tra la folla, smarrirsi - izgubiti se u mnoštvu, zalutati' ne može se razumjeti na temelju značenja pojedinih sastavnica. Značenje je toga idioma potrebno poznavati, i u slučaju izvornoga govornika koji mora naučiti značenje frazema.

Međutim, sastavnica tal. Cafarnao, hrv. Kafarnaum, ime drevnoga galilejskog grada na sjeverozapadnoj obali Tiberijadskoga jezera, sela koje danas Arapi nazivaju Tell Hum, poznato je prema svetopisamskim opisima kao kaotičan, turbulentan grad, grad u kojemu Isus u sinagogi drži propovijedi i obećava euharistiju i stoga se ta sastavnica, premda dijelom semantički neprozirnoga idioma, može držati autonomnom jer i izvan toga idioma ima slično značenje.

Ta semantička djeljivost osobito vrijedi za idiome biblijskoga podrijetla s vlastitim imenima, toponimima, hidronimima itd.

\subsection{Semantičke značajke frazema}

Na temelju svega dosad iznesenog jasno je da frazemi u semantičkome području imaju obilježja koja ih čine različnima od nefrazeoloških sveza riječi i riječi.

Međutim, tek kad je semantika dopunila gramatički opis, „omogućeno je istraživanje frazeoloških jedinica“ (Chrissou 2000, 19) u znanstvenome smislu riječi.

Njihova osobita struktura značenja posljedica je činjenice da njihovim sastavnicama nedostaje samostalnost koja ih obilježava kada su sastavnicama slobodnih sveza. A to se odnosi i na njihovu semantiku kao i na njihovu gramatičku funkciju. Jedno od bitnih obilježja jest asimetrija razine izraza i sadržaja, dakle mogućnost strukturne raščlambe frazeološkoga formativa nema podudarnost na semantičkoj razini““ (usp. Chrissou 2000, 21). 
Premda pojmovi kao polisemija, sinonimija, ekspresivnost itd. nisu ograničeni samo na frazeologiju, svakako je zanimljivo promotriti te odnose i među frazemima, osobito među frazemima biblijskoga podrijetla u talijanskome i hrvatskome jeziku. I to su svakako bitna obilježja čije teorijsko produbljivanje i istraživanje omogućuje dublje shvaćanje samoga pojma frazema, njegovih posebnosti, ali i odnosa prema ekvivalentima u drugim jezicima.

\subsubsection{Polisemija}

Polisemija je pojava poznata u semantici i predstavlja „obilježje prema kojemu je riječi ili jezičnom obliku svojstveno više značenja, a ne samo jedno. Polisemija je jedan od temeljnih funkcionalnih čimbenika u jeziku jer omogućava govorniku racionalno i ekonomično korištenje već postojećega leksičkog inventara tako da se postojećim riječima pridaju nova značenja““ ${ }^{8}$

Kao i kod riječi, i kod frazema zamjetna je polisemija, dakle mogućnost da jedan frazem ima više značenja. Prema Burgeru $(2015,72)$ polisemija je „doduše puno rjeđa pojava kod frazema nego kod riječi gdje je polisemija prije pravilo nego izuzetak“، ${ }^{89}$

Primjerice, $\mathrm{u}$ korpusu frazema biblijskoga podrijetla u hrvatskome pojavljuje se frazem:

\section{Izabrani narod}

1) Izrael, Židovi

2) ljudi koji uživaju naročite povlastice.

U korpusu frazema biblijskoga podrijetla u talijanskome frazem voce nel deserto ima dva značenja:

a) Fig.: parole, raccomandazioni, consigli, ammonimenti e simili che non vengono ascoltati

b) riferito inoltre a idee o insegnamenti che non trovano seguito.

Već prvo frazeološko značenje frazema izabrani narod predstavlja metonimiju (ili metaforu), a drugo (ili eventualno treće) frazeološko značenje je tada metafora. Polisemija se

\footnotetext{
${ }^{88}<$ http://www.enciklopedija.hr/natuknica.aspx?id=49218> (10.9.2019.).

${ }^{89}$ Oko pitanja polisemije ne postoji suglasje u frazeološkoj literaturi. Palm $(1997,53)$ primjerice tvrdi da je polisemija česta pojava kod frazema.
} 
dakle očituje kao stupnjevitost apstrakcije. Stoga se u tom slučaju govori o sekundarnoj (ili tercijarnoj) metaforizaciji (usp. Burger 2015, 72).

U korpusu frazema biblijskoga podrijetla u talijanskome i hrvatskome jeziku nismo naišli na mnogo primjera polisemnih frazema. Posrijedi je dakle, u skladu s gore spomenutim Burgerovim spoznajama (usp. Burger 2015, 72) rjeđa pojava u frazeologiji.

Često je k tome nejasno je li posrijedi polisemija ili homonimija i odluka ovisi o vlastitoj prosudbi istraživača. Problematiziranje pojmova polisemije i homonimije osobito je važno prilikom stvaranja ekvivalencije između dvaju jezika ili među više njih. Ako se ustvrdi da je posrijedi homonimija, „dva se frazema mogu držati potpunim ekvivalentima (odnos 1:1)“ (Chrissou 2000, 28). Ako se pak ide u smjeru polisemije, ,može doći do toga da unatoč istomu denotativnom značenju postoje asimetrije u opsegu značenja dviju jedinica““ (isto).

\subsubsection{Sinonimija}

Pojmom sinonim u jezikoslovlju se označavaju dva ili više leksema jednoga jezika koji imaju isto ili pak slično značenje. Neki semantičari čak tvrde da ne postoje potpuni sinonimi ili istoznačnice. Eventualno se priznaje da postoje djelomični sinonimi ili bliskoznačnice.

Uzmimo primjerice viso-volto-faccia; opposto-contrario, scuro-buio u talijanskome jeziku. Svaka riječ ima vlastita obilježja ,glede semantičkih sastavnica, stilskih razina, područja uporabe, zemljopisne proširenosti itd., koja je čine, premda u manjoj mjeri, različnom od drugih bliskih riječi“ 90

Napomenuli smo da je polisemija pojava iznimno proširena među leksemima, rjeđa pojava među frazemima. Međutim, za sinonimiju vrijedi obrnuto. Sinonimija je česta pojava upravo u frazemskome inventaru jednoga jezika. Upravo frazeologija pokazuje „brojna sadržajna područja koja su uvelike pokrivena - već prema procjeni - posvemašnjim ili pak gotovo posvemašnjim sinonimima“" (Burger 2015, 73).

Prema Fleicheru frazeološki su sinomimi „frazemi u kojima se podudaraju barem bitna značenjska obilježja. Mogu se dakako razlikovati u sekundarnim značenjskim obilježjima, u stilskoj obilježenosti, u sintaktičkome načinu tvorbe (valenciji)“ (1997, 178). I on također

\footnotetext{
$90<$ http://www.treccani.it/enciclopedia/sinonimo/> (12.9.2019.).
} 
ustvrđuje da je ,sinonimija u slučaju tvorbenih konstrukcija izraženija u usporedbi s osnovicama“" (isto).

Palm $(1997,49)$ napominje da frazeološke sveze riječi koje ponajprije pokrivaju ljudske emocije, a posrijedi su nerijetko oblici ponašanja i situacije koje jezična zajednica negativno vrjednuje, služe frazeološkomu imenovanju. I upravo se na tome području, onomasiološki gledano, razvila bogata sinonimija. Riječ je uglavnom o neugodnim oblicima ponašanja kao ravnodušnost, nemar, odbacivanje, samohvala, lakomost, prijetnja, pokuda, gnjavljenje itd.

Budimir $(2020,119)$ razlikuje k tome dvije vrste frazemske sinonimije: međufrazemsku i unutarfazemsku, uz napomenu da je apsolutna sinonimija rijetka u obama slučajevima.

I u korpusu frazema biblijskoga podrijetla u talijanskome i hrvatskome jeziku naišli smo na brojne istoznačnice i bliskoznačnice, bilo međusobno bilo s drugim frazemima koji ne pripadaju mikrosustavu frazema biblijskoga podrijetla.

Tako primjerice da bismo u talijanskome jeziku izrazili da je netko prijetvoran i licemjer možemo rabiti frazem:

essere un fariseo, ali isto tako essere un sepolcro imbiancato.

I u hrvatskome imamo frazeme koji su potpuni ekvivalenti:

bitifarizej, ali također i biti okrečen (obijeljen) grob.

Da bismo u talijanskome rekli da je netko vrlo star, imamo na raspolaganju više frazema biblijskoga podrijetla i njihovih inačica:

esser vecchio quanto l'alleluia; essere un matusalemme; avere gli anni di Matusalemme; avere l'età di Matusalemme; vecchio come Matusalemme; avere gli anni di Noè; vecchio come Noè; vecchio come l'arca di Noè.

U hrvatskome to također možemo izreći frazemima:

biti star kao Biblija ili biti star kao Metuzalem (metuzalemski star).

I u talijanskome i u hrvatskome jeziku postoje i drugi frazemi koji izriču, s primjesom podrugljivosti, da je netko iznimno star, primjerice:

- u talijanskome: essere più vecchio del prezzemolo; vecchio come il cucco 
- u hrvatskome: star kao Grčka itd.

Da bismo izrekli da nekoga šaljemo bespotrebno s jednoga mjesta na drugo, možemo se poslužiti dvama frazemima:

- u talijanskome: mandare qualcuno da Erode a Pilato kao češći oblik i mandare da Ponzio a Pilato kao rjeđi oblik.

- u hrvatskome: slati koga od Poncija do Pilata kao češći oblik i slati koga od Heroda (Iruda) do Pilata kao rjeđi oblik. ${ }^{91}$

Premda oba frazema i u talijanskome i u hrvatskome izriču istu koncepciju, ipak nije riječ o istoznačnicama, nego o bliskoznačnicama, a najčešće ih se prikazuje kao frazem s inačicama.

To vrijedi i za mnoge druge frazeme u kojima se rabe umanjenice i sl. Nameće se pitanje jesu li posrijedi sinonimi ili nisu.

Proost (2007 prema Burger 2015, 73) stavlja u pitanje mišljenje da je sinonimija na području frazeologije razvijenija nego na području leksika. Ona upozorava da se idiomi s različnom „slikovitošću“ barem na konotativnoj razini ne mogu držati potpunim sinonimima.

Burger $(2015,75)$ se pita igra li „slika“ uistinu ulogu za značenje frazema i drži da će se o tome još morati raspravljati i zaključuje da procjena problema sinonimije svakako ovisi o odgovoru na to pitanje.

\subsubsection{Složenost}

Često u frazeološkim radovima možemo naići na tvrdnju da su frazemi u pravilu semantički složeniji od riječi. Složenost (kompleksnost) „karakteristična je za frazeološke znakove. Njihova složenost stvara se uglavnom nedostatkom regularnoga odnosa forme $\mathrm{i}$ sadržaja“ (Chrissou 2000, 118). Tako primjerice u skladu s terminologijom semičke raščlambe frazemi uz semantičku jezgru raspolažu s više ,semova koji služe diferencijaciji i konkretizaciji“ (Wotjak 1992, 24 prema Burger 2015, 74).

\footnotetext{
${ }^{91}$ Neki su autori mišljenja da ti frazemi nisu istoznačnice. Međutim, u skladu s uporabom u hrvatskome svrstali smo ih u jedan frazem s inačicama.
} 
Primjerice za objašnjenje frazema biblijskoga podrijetla u hrvatskome:

Razmetni (rasipni, izgubljeni, bludni) sin naći ćemo objašnjenje: 'osoba koja je napustila svoje društvo / svoju zajednicu / obitelj i skrenula s pravoga puta, čovjek koji je zabludio / koji je na pogrješnomu životnom putu'.

Ili u talijanskome korpusu:

dare a intendere che Cristo è morto di sonno (pop): 'Fig.: raccontare menzogne inverosimili, far credere cose assurde, spesso per trarne qualche vantaggio. Anche dare a intendere una cosa per un'altra'.

Prema Burgeru semantička kompleksnost pokazuje se u tekstovima kod idioma koji su kompozicionalno strukturirani te kod kinegrama koji se istodobno odnose na neverbalno ponašanje i njegovo simboličko značenje. Takav stupanj kompleksnosti ne pojavljuje se na isti način u slučaju riječi (usp. Burger 2000, 75).

Budući da su frazemi biblijskoga podrijetla nerijetko iz viših registara, počesto i kalkovi preuzeti iz prijevoda iz drugih jezika, može se zaključiti da su uglavnom semantički složeni.

Njihova semantička složenost ne priječi da se rabe i u narječjima, razgovornome jeziku, nižim registrima. Uronjenost u kršćansku kulturu i dobro poznavanje biblijskih tekstova ili scena, bilo čitanjem ili slušanjem te poglavito razmatranjem svetopisamskih tekstova ili promatranjem naslikanih biblijskih prizora po katedralama i prošteništima, opatijama i samostanima omogućila je da frazemi biblijskoga podrijetla duboko prožmu cjelokupnu kulturu i jezik kršćanskih naroda.

\subsubsection{Neodređenost}

Neodređenost frazema također je čest pojam na koji se može naići u literaturi. No moglo bi se pomisliti da je posrijedi protuslovlje onomu što je navedeno u prošlome poglavlju.

Neodređenost ili ambigvitet drži se pak tipičnim semantičkim obilježjem frazema (usp. Chrissou 2000, 26; Burger 2015, 75). Pod neodređenosti misli se na obilježje frazema da mogu opisati različite stvari, čak i vrlo složene osjećaje, iskustva ili činjenice na jednostavan i svima shvatljiv način. Time se svakako pojednostavljuje komunikacija i frazemi bitno pridonose ekonomiji u jeziku. Struktura frazema upravo omogućuje kreativnost u njihovoj uporabi. 
Černyševa (1984, 21 prema Chrissou 2000, 26) neodređenost definira kao „maksimalno apstrahirano značenje koje tek kod izoliranoga spominjanja ovisi od kontekstualizacijāa“.

Taj kriterij, koji se pokazuje vrlo problematičnim za semantičku teoriju jer krši načela jasnoga dodjeljivanja značenja, za frazeologiju je konstitutivan (usp. Palm 1994, 437).

Prema Burgeru frazemi mogu biti takozvane ,,prazne formule“ $(2015,76)$. U različitim tekstovima one se popunjavaju različitim sadržajima. Ta vrsta neodređenosti „nije prvenstveno semantičko obilježje frazema, nego proizvod tekstnolingvističkoga uključivanja (odnosno izostanka uključivanja)“ (isto). Primjerice, hrvatski frazem borba Davida $i$ Golijata jest metaforična formulacija kojom se izriče da je posrijedi neravnopravna borba i taj se frazem može primijeniti na različite situacije. Isto vrijedi i za talijanski frazem bere l'amaro calice što znači 'podnositi neugodnu situaciju, patnju' i sl.

Prema tomu ,ambigvitet koji ih obilježava na razini sustava, tek se dokida na razini teksta“" (Chrissou 2000, 127).

Osim idioma neodređenost je obilježje i formula tipičnih za razgovor. Tu pak nije posrijedi neodređenost $\mathrm{u}$ semantičkome, nego u funkcionalnome smislu. Za ostale tipove frazema neodređenost se bitno ne razlikuje u usporedbi s riječima (usp. Burger 2015, 76 - 77).

I u slučaju neodređenosti za frazeme biblijskoga podrijetla u obama jezicima može se ustvrditi da se rabe u posvema različnim jezičnim situacijama, u svim registrima i za opis raznih situacija. Usprkos svojoj semantičkoj složenosti vrlo su pogodni za uključenje u različite vrste tekstova. Za neke frazeme biblijskoga podrijetla na prvi pogled ne bi se niti prepoznalo odakle potječu da ne postoje frazeološki rječnici koji objašnjavaju njihovo podrijetlo.

\subsubsection{Ekspresivnost}

Ekspresivnost frazema također je jedno od obilježja koje se nerijetko spominje i u samoj definiciji frazema (usp. primjerice Vidović Bolt 2011, 19). To je svakako obilježje koje mnogi povezuju s frazemima općenito premda to ne vrijedi za sve frazeme u istoj mjeri. U frazeološkoj literaturi vlada suglasje da je ekspresivnost kod frazema jače izražena nego u ostalome leksiku. 
Postoje i različni pristupi stilističkoj prosudbi frazema, ali u frazeologiji odnosno frazeografiji ne postoje jedinstveni kriteriji tako da se takva prosudba često čini subjektivnom (usp. Chrissou 2000, 40).

Burger $(2015,77)$ drži da se pod tim pojmom skrivaju mnogi vidovi i rabi naziv „konotativna viša vrijednost“ jer frazemi imaju konotativni plus u usporedbi s riječima ili slobodnim svezama riječi.

Pod pojmom ekspresivnosti podrazumijeva se niz stilističkih fenomena koji su tipični za frazeme. „S jedne strane s ekspresivnošću se povezuje apelativna i intezivirajuća funkcija koja je - drukčija nego u slučaju leksema - tipična za frazeme i odražava se na iskaz (Chrissou 2000, 39). S druge se pak strane stilističko obilježje ekspresivnosti „dovodi u vezu sa semantičkom višom vrijednošću frazeoloških jedinica na temelju čega se određuje razlika od slobodnih sveza riječi“" (isto).

S ekspresivnošću usko su povezani i pojmovi slikovitosti i zornosti, tj. sposobnosti da se kod slušatelja / čitatelja stvori zorna predodžba pojave. Lingvističkim čimbenicima slikovitosti drže se poglavito usporedba, metafora i metonimija (usp. Chrissou 2000, 39 - 40). Važno je pak pripomenuti da se slikovitost prema uvjerenju osobito frazeologa u širemu smislu drži obilježjem određenih frazemskih vrsta, a ne frazema općenito (usp. Farø 2015, 227), no za frazeme biblijskoga podrijetla uglavnom je prepoznatljivo obilježje.

Zahvaljujući crkvenomu slikarstvu, freskopisu i ikonopisu, kiparstvu i duborezu, ali i „Bibliji siromašnih“,92 svečanim liturgijama, baroknomu kazalištu, pučkim pobožnostima, križnim putovima i procesijama, štovanju svetačkih relikvija osobito u katoličkim zemljama mnogi frazemi biblijskoga podrijetla poprimaju na osobit način visok stupanj slikovitosti i zornosti i rabe ih svi slojevi društva upravo poradi toga konotativnog plusa jer se njihovom uporabom evociraju događanja koja su duboko proživljavana sudjelovanjem na obredima, procesijama, promatranjem i razmatranjem biblijskih prizora po crkvama i katedralama. Njihova uporaba, zahvaljujući već gore spomenutim obilježjima semantičke složenosti uz mogućnost uključivanja u razne vrste tekstova, uz izraženi konotativni plus koji posjeduju, čini ih frazemima par excellance, frazemima duboko ukorijenjenima u europsku književnost, kulturu, ali i usmenu književnost i govorni jezik svih slojeva društva. Stoga ne čudi da i u

\footnotetext{
${ }_{92}$ Biblija pauperum - crtežima ilustrirani rukopisi povijesno-spasenjskih događaja Novoga zavjeta u XIII. i XIV. st., u XV. st. drvorezima ilustrirana i tiskana tzv. Blockbuch izdanja, sadrže slike i jezgrovite tekstove usporednih prizora iz Staroga i Novoga zavjeta. Namijenjene su bile siromašnomu seoskom svećenstvu i redovnicima kao priručnik za propovijedi. $<$ https://www.enciklopedija.hr/natuknica.aspx?id=7452> (10.2.2020.).
} 
narječjima postoji mnoštvo frazema biblijskoga podrijetla te kristijanizama i „liturgizama“ koji se rabe i u nižim registrima i koji služe i u običnim svagdanjim razgovorima, opisima i pripovijedanju i poznaju ih i rabe ljudi koji nisu čitali velika djela europske književnosti niti sjedili po kazalištima.

Mnoge anegdote i šale o porabi toga tipa frazema javljaju se na onim područjima gdje se susreću govornici hrvatskoga jezika s govornicima bliskih slavenskih idioma kao primjerice srpskoga i bošnjačkoga koji ne poznaju frazeologiju poniklu iz katoličke tradicije. Govornici tih jezika kadikad nisu kadri razumjeti im značenje i smisao, a stariji i čak neuki govornici hrvatskoga vrlo ih suvereno rabe, kadšto i nesvjesni da ih drugi ne razumiju ili pogrješno razumiju, a $\mathrm{k}$ tome ih još umješno modificiraju i prilagođavaju gdjekad i vrlo složenim izričajima, obratima i sveprisutnim igrama riječi čak i u najobičnijoj svagdašnjoj komunikaciji koja je navlastito u južnim krajevima povezana s izražajnim gestama, izmjenom intonacije i porabom drugih suprasegmentalnih obilježja te akrobacijom $\mathrm{s}$ paralingvističkim i ekstralingvističkim fenomenima. Koliko su duboko u hrvatsku kulturu ukorijenjeni frazemi biblijskoga podrijetla, vidljivo je u mnogim serijama i filmovima u kojima se na šaljiv način tematiziraju komunističke zabrane uporabe frazema, poslovica, krilatica biblijskoga podrijetla i uopće religioznoga predznaka, ali i primjerice nerazumijevanje regionalnih frazema u drugim hrvatskim krajevima te prijezir počesto tuđinskih i režimskih činovnika, sudaca i policajaca prema nadasve bogatoj i izvornoj kulturnoj baštini malenoga hrvatskog čovjeka čiji je jezik, kultura i svjetonazor natopljen mudrošću biblijskoga govora, a koju je on na svoj način izrazio i pretočio u svagdašnje življenje. ${ }^{93}$

\footnotetext{
${ }^{93}$ Nepravdu koja je počinjena baštini frazema biblijskoga podrijetla, njihovom zabranom ili povezivanjem sa zatucanošću i ruralnim uzrečicama neprosvijećenih i reakcionarnih kmetova, nije lako ispraviti. $\mathrm{K}$ tome, upravo su frazemi i paremije biblijskoga podrijetla bili i ostaju gotovo nepremostivom preprekom za bilo kakav pokušaj utapanja hrvatskoga jezika u regionalne jezične eksperimente. Veliko zanimanje za usmenu književnost općenito te za sve izvorno i drevno moglo bi barem djelomično biti zadovoljština i poticaj za ponovno vrednovanje ovoga blaga hrvatskoga naroda. Nadamo se da će i sve veće zanimanje za historijsku i arealnu frazeologiju također dati svoj prinos proučavanju frazema biblijskoga podrijetla.
} 


\section{EKVIVALENTNOST TALIJANSKIH I HRVATSKIH FRAZEMA BIBLIJSKOGA PODRIJETLA}

Kao što je napomenuto u više navrata, ekvivalentnost je jedan od temeljnih pojmova usporedbe dvaju ili više jezika. Jezike se znanstveno može proučavati samo uz usporedbu: bilo s genetski srodnim i nesrodnim jezicima, s jezicima obližnjih naroda, ali i s egzotičnim jezicima drugih kontinenata; kako s današnjim živim jezicima, tako i s izumrlima.

O ekvivalentnosti možemo govoriti i u unutarjezičnim istraživanjima, bilo $u$ sinkronijskome presijeku (primjerice $\mathrm{u}$ arealnim istraživanjima) ili pak u dijakronijskim istraživanjima i kontrastiranju s minulim epohama nekoga jezika.

To isto vrijedi i za frazeološka istraživanja i kako je već navedeno u poglavlju o zadaćama kontrastivne (poredbene) frazeologije (usp. § 2.4.), kontrastivna frazeologija postoji od početaka kontrastivne lingvistike i frazeoloških istraživanja od šezdesetih godina prošloga stoljeća.

\subsection{Pojam ekvivalentnosti}

Sam pojam ekvivalencija ili ekvivalentnost znači jednakost ili jednaka vrijednost. Pojam se ekvivalentnosti u jezikoslovlju tradicionalno identificira sa semantičkom jednakošću (usp. Farø 2004). U usporedbi frazeoloških sustava ili subsustava dvaju jezika postoje različiti stupnjevi ekvivalentnosti pri čemu se pod pojmom ekvivalentnosti podrazumijeva „komunikativna podudarnost između polaznoga i ciljnoga jezika koja se može ustvrditi kod jedne jedinice. Ona se postiže maksimalnim podudaranjem denotata, konotata i funkcionalnosti te također i formalne strukture i broja sastavnica“ (Zeman 2006, 398).

U kontrastivnoj frazeologiji neosporna je ključna važnost ovoga pojma, međutim, Chrissou drži da je ,potraga za točnom definicijom ove pojave koja bi obuhvaćala sve vidove fenomena koji se određuje bez vidljivih rezultata“ $(2000$, 98). I prema Kolleru pojam je ekvivalentnosti i u konfrontativnoj lingvistici kao i u traduktologiji „neprecizan i heurističkitentativan“ (Koller 1979).

Denotativno značenje frazema prema Zemanu (2006, 306) pri određivanju ekvivalentnosti ,zauzima povlašteno mjesto u međujezičnoj usporedbi“. To pak ne znači da i 
konotacije nisu važne jer u oblikovanju cjelokupnoga značenja igraju također ulogu, međutim „,ipak se denotativnoj značenjskoj sastavnici treba dati prvenstvo kao temelju usporedbe jer ona u cjelokupnome frazeološkom značenju ima najveći i najvažniji udio“ (isto). U supostavnoj raščlambi poglavito se dakle uzima $u$ obzir asimetrija glede denotativnoga značenja frazeoloških jedinica i ponajprije se upozorava na nejednakost opsega značenja. Denotativno značenje često je uže u jednome jeziku u usporedbi s drugim itd. To dakako vrijedi i za jezike koji nisu genetski srodni, ali su u stalnome neposrednom doticaju, kao primjerice talijanski i hrvatski jezik.

Valja pripomenuti da se u novijim kontrastivnim modelima opisa $u$ međujezičnoj usporedbi frazema uzima u obzir niz kriterija: uz frazeološko značenje (ekvivalenciju) također i gramatička forma (morfologija i sintaksa / konvergencija), doslovno cjelovito značenje i s time povezana slika. Formalna sličnost frazema općenito se naziva konvergencijom, a njihova različitost divergencijom. Konvergencija obuhvaća u lingvističkome smislu potpunu i djelomičnu ekvivalentnost. Dok su kod konvergencije međujezične razlike uvjetovane jezičnim sustavom, kod ekvivalencije je posrijedi semantičko, odnosno semantičko-pragmatičko funkcionalno određenje (dakle funkcionalno promatranje) frazema dvaju jezika. (usp. Komenda-Earle 2009, 65).

\subsection{Razine međujezične usporedbe}

Interlingvalna konfrontacija odnosno međujezična usporedba u svakome slučaju rasvjetljuje brojne vidove u razumijevanju frazema unutar jednoga jezika. Tom raščlambom upotpunjuju se spoznaje o frazemima biblijskoga podrijetla u talijanskome i hrvatskome jeziku i popunja se praznina jer se dosad nisu sustavno uspoređivali. Polazni jezik te usporedbe jest talijanski, a ciljni hrvatski jezik. Međujezična usporedba osobito je plodna i „s kulturnoantropološkoga stajališta. Budući da su frazemi proizvodi jedne kulture, povijesti i zemljopisnopolitičkoga položaja neke zemlje, oni odražavaju kolektivnu i individualnu maštu jednoga naroda i time reflektiraju njegovo stvarateljsko mišljenje“" (Chrissou 2000, 6). Unatoč činjenici da talijanski i hrvatski stricto sensu nisu genetski srodni, posrijedi su jezici naroda koji stoljećima žive u neposrednoj blizini i „na temelju jezičnih dodira postoji velika sličnost u frazeološkim sustavima. Time se misli na zajednička obilježja u svijesti, društvenim procesima, kulturi kao i sveopće zakone i općenite semantičke mehanizme“ (Malá 1999, 50). 
U okviru ovoga poglavlja osobito ćemo se pozabaviti denotativnim značenjem, doslovnim značenjem, strukturom, stilskom vrijednošću i potom ćemo iznijeti zaključne napomene.

\subsubsection{Denotativno značenje}

Frazemi se mogu uspoređivati i polazeći od oblika, međutim „u većini slučajeva međujezična usporedba frazema temelji se na značenjskome identitetu na denotativnoj razini (Korhonen 2007, 575) te se stoga denotativno značenje drži nužnom pretpostavkom za „međujezičnu usporedbu frazema s praktičnim ciljem i istodobno se može definirati dominantnim čimbenikom određenja ekvivalentnosti““ (Korhonen 2007, 576).

Već je spomenuto (usp. § 13.1.) da u međujezičnoj usporedbi frazema posebno mjesto pripada denotativnomu značenju. Prvenstvo toga kriterija među ostalim kriterijima međujezične usporedbe leži u činjenici ,da je ono minimalna pretpostavka s drugih stajališta. Poradi toga njemu se priznaje prevladavajuće mjesto usuprot doslovnome značenju, strukturi i stilskoj vrijednosti jer mu u stvaranju frazeološkoga cjelovitog značenja pripada velika vrijednost" (Chrissou 2000, 121).

Valja napomenuti da navodi koje rječnici donose počesto nisu detaljni glede svih značenja koje frazem može poprimiti, međutim Chrissou $(2000,123)$ je mišljenja da se „njihov analitički pristup svakako može iskoristiti kao okvir za frazeografsko obuhvaćanje čvrstih sveza riječi“ pri čemu se može primijetiti da je to u apsolutnome smislu ipak nemoguće jer se jedva mogu odrediti granice mogućoj „Bedeutungsfärbung, die ein Phraseologismus im Gebrauch annehmen kann“ (isto).

\subsubsection{Doslovno značenje}

Činjenica da su frazemi nastali sekundarnom tvorbom od primarnih jezičnih znakova utječe i na međujezičnu supostavnu raščlambu. S obzirom na to u istraživanju sličnosti i razlika frazeoloških jedinica dvaju jezika valja se pozabaviti i doslovnim značenjem frazema koje je temelj motiviranosti samoga frazema. 
Zeman (2006, 306) upućuje na važnost uzimanja u obzir i doslovnoga značenja i napominje: „wesentliche Erkenntnisse können zum Verhältnis von Sprache und Denken gewonnen, Parallelen und Unterschiede im so genannten soziokulturellen Deutungssystem festgestellt werden. Auf Grund dieses soziokulturellen Deutungssystems, der unterschiedlichen Bildhaftigkeit, können interessante Ergebnisse gewonnen werden“.

Važnost usporedbe doslovnoga značenja za supostavnu raščlambu naglašava i Chrissou (2000, 127) „poglavito poradi uske povezanosti sa sinkronijskom motiviranošću i s pragmatičkom snagom frazema, a ono se ostvaruju u određenome surječju (djelomičnim) aktiviranjem doslovnoga načina čitanja“. Osobit problem u usporedbi doslovnoga značenja $u$ talijanskome i hrvatskome svakako su frazeološki vezane sastavnice u frazemima obaju jezika, ali i primjerice latinski frazemi koji se rabe u talijanskome. Samim doslovnim prijevodom s talijanskoga na hrvatski ne može se prenijeti razlika u uporabi talijanskih i latinskih sastavnica jer latinski frazemi u talijanskome ipak nisu ksenofrazemi kao u hrvatskome i stoga se i navode u frazeološkim rječnicima.

Osim toga, važno je da frazem u polaznome i u ciljnome jeziku glede sastavnica barem u dvjema sastavnicama ima leksičke podudarnosti pri čemu se zbog različite strukture dvaju jezika, primjerice nepostojanja nominalne fleksije u talijanskome i određenoga i neodređenoga člana u hrvatskome itd. ne može očekivati podudarnost nepunoznačnih (sinsemantičnih) riječi. Hrvatski se genitiv i dativ tako u talijanskome izriču prijedlogom di+imenica i prijedlogom a+imenica; također i posvojni pridjev, a u hrvatskome se besprijedložni genitiv ili dativ te posvojni pridjev izriču jednom riječju. U talijanskome se rabi određeni ili neodređeni član, a u hrvatskome ne postoji nikakav oblik premda se kojiput rabi broj jedan. Pri tome je važno napomenuti da je u supostavnoj raščlambi subsustava dvaju jezika svakako važnija „konvergencija autosemantičnih nego sinsemantičnih riječi“ (Chrissou 2000, 129). To osobito vrijedi za jezike kao talijanski i hrvatski koji ne pripadaju istoj grani indoeuropskih jezika te su time genetski nesrodni.

\subsubsection{Struktura}

Pod strukturom podrazumijevamo s jedne strane morfološko-gramatičke vidove koji se tiču tvorbe riječi i morfologije, a s druge strane i sintaktičke vidove koji se tiču odnosa unutar samoga izraza, njegovih sastavnica i njihova broja te broja i vrste dopuna koje uvjetuje valencija 
frazema (usp. Chrisssou 2000, 130). Taj kriterij na osobit način rasvjetljava primjerice tipološku različitost među jezicima. Strukturni je vid ujedno kadšto usko povezan s leskičkosemantičkim. Posebne strukture imaju skupine kao leksički binomi, frazeološke usporedbe itd. (usp. Malá 1999, 53).

Talijanski i hrvatski jezik pripadaju skupini flektivnih jezika i tipološki su slični. Imaju relativno slobodan red riječi i linearni slijed sastavnica ne pokazuje znatna odstupanja. U obama jezicima u podtipu glagolskih frazema glagol se navodi u infinitivu. Niječni se oblik tvori predmetanjem niječne čestice. I u talijanskome i hrvatskome postoji sličan tip bezsubjektne rečenice. Oba jezika imaju vrlo sličnu podjelu na vrste riječi, glede broja poznaju jedninu i množinu. Hrvatski jezik ima tri roda, a talijanski samo dva, ali to bitno ne utječe na frazeme biblijskoga podrijetla. Međutim, valja upozoriti na neke temeljne strukturne razlike koje dolaze do izražaja u korpusu frazema biblijskoga podrijetla:

1. Talijanski jezik ne poznaje nominalnu fleksiju pa se često nešto izrečeno besprijedložnim genitivnom ili dativom izriče prijedložnim izrazom i zbog toga je u talijanskome zamjetan veći broj prijedloga.

2. Postojanje padeža u hrvatskome omogućuje ipak slobodniji slijed sastavnica koji u talijanskome često nije moguć.

3. Zamjetna je različita glagolska rekcija nekih glagola koji zahtijevaju različne dopune u talijanskome i hrvatskome.

4. Postoje i razlike u položaju atributivnoga pridjeva u dvama jezicima, u talijanskome iza imenice, ali i ispred imenice kojoj pripada, a u hrvatskome uglavnom ispred imenice.

5. U talijanskome se rabi određeni i neodređeni član koji hrvatski jezik ne poznaje.

6. U hrvatskim se frazemima glagolskoga podtipa uglavnom glagol navodi u infinitivu: svršeni glagol kojemu se dodaje njegov nesvršeni parnjak ili čak i obratno jer se glagoli u hrvatskome već u infinitivu razlikuju po vidu, dok talijanski glagoli mogu izricati i perfektivnost i imperfektivnost i ne postoje svršeni ili nesvršeni parnjaci u infinitivu.

7. U nekim talijanskim frazemima biblijskoga podrijetla pojavljuje se glagolski način konjunktiv koji standardni hrvatski jezik ne poznaje. 
8. U talijanskim frazemima zamjetna je uporaba pasiva, trpnoga glagolskog stanja koje se u hrvatskome rjeđe rabi.

9. Među talijanskim glagolima pojavljuju se pronominalni glagoli nepoznati hrvatskomu jeziku.

10. U hrvatskome se u nekim frazemima rabi poimeničeni glagolski prilog sadašnji koji se u talijanskome ne pojavljuje.

11. U talijanskome se korpusu pojavljuje kauzativna konstrukcija s glagolom fare koja ne postoji u hrvatskome standardnom jeziku.

Neke od tih razlika bitno ne utječu na same frazeme i postoje čak kao malene razlike i u frazemima koje smo svrstali u skupinu potpune ekvivalentnosti jer se time ne mijenja denotativno značenje niti to utječe na podudarnost autosemantičnih sastavnica.

\subsubsection{Stilska vrijednost}

Nije lako opisati stilsku vrijednost frazema, osobito frazema biblijskoga podrijetla premda stilska vrijednost u međujezičnoj usporedbi svakako igra ulogu. Stilska vrijednost odnosno ekspresivni karakter frazema „nije moguće opisati na odgovarajući način izvan konteksta.[...] Konotativnu vrijednost teško je dodijeliti jednomu frazemu kao konstantnu veličinu, tj. kao jedinicu leksikona“" (Chrissou 2000, 135). Ipak, ne bi bilo primjereno tvrditi da je stilsku vrijednost poradi njezine jezične i situacijske povezanosti s kontekstom ,posvema nemoguće opisati sa stajališta jezičnoga sustava. Moguće je frazeme stilski označiti premda ovo pregnuće može biti samo tentativno i može se potvrditi samo verifikacijom u kontekstu“ (isto).

U talijanskome se uz određeni frazem gdjegdje rabi evalutivna oznaka kao raro, pop., što ni u hrvatskome nije tradicija za razliku primjerice od njemačkoga gdje je to duga tradicija i rabe se pojmovi kao „salopp, derb, umgangssprachlich, jugendsprachlich, abwertend, scherzhaft, veraltend, gehoben und bildungssprachlich“(Chrissou 2000, 137).

Za međujezičnu usporedbu frazema stilska vrijednost itekako igra ulogu premda i sami znamo da se određeni frazem već prema kontekstu može rabiti za različite svrhe i da je to leksikografski gotovo nemoguće obuhvatiti. 
Kako frazemi biblijskoga podrijetla potječu iz istoga izvora, a ovdje je posrijedi supostavna raščlamba frazema preuzetih iz frazeoloških rječnika koji odražavaju sinkronijski presjek njihove porabe u standardnojezičnoj inačici, talijanskoj i hrvatskoj, nismo zamijetili osobite razlike u stilskoj vrijednosti koje bi bitno utjecale na ishod ove međujezične usporedbe. ${ }^{94} \mathrm{U}$ nekim primjerima u kojima bi se moglo govoriti o porabi uglavnom u nekome posebnom registru, posrijedi su najčešće frazemi prisutni samo u jednome jeziku koji nemaju jednakovrijednicu u drugome jeziku.

\subsubsection{Zaključne napomene}

Može se dakle zaključiti da spomenuti parametri dobro funkcioniraju u međujezičnoj usporedbi. Anomalije koje su vidljive kod određivanja ekvivalentnosti uvjetovane su genetskom različnošću talijanskoga i hrvatskoga jezika, različnim tipološkim obilježjima i povijesnim razvojem koji je kadikad imao posve drukčije ishode.

U ovoj međujezičnoj supostavnoj raščlambi polazit ćemo od denotativnoga značenja kao minimalne pretpostavke usporedbe subsustava frazema biblijskoga podrijetla u dvama jezicima. S obzirom na distribuciju drugih kriterija formulirat ćemo podtipove djelomične ekvivalentnosti pri čemu ćemo osobito usmjeriti pozornost na divergencije „u doslovnome značenju, strukturi i stilskoj obilježenosti“ (Chrissou 2000, 140). U slučaju izostanka podudarnosti primjere ćemo svrstati u tip čisto semantičke ili nulte ekvivalentnosti.

\subsection{Tipovi ekvivalentnosti}

Kao što je gore već spomenuto, postoje različiti tipovi ekvivalentnosti između frazema dvaju ili među frazemima više jezika, odnosno određenih subsustava. Subsustav ili mikrosustav shvaća se u smislu „sustavno uređenoga dijela frazeološki povezanoga leksika jednoga jezika“ (usp. Burger; Buhofer; Sialm 1982, 376). Obično se ekvivalentnost dijeli na potpunu i djelomičnu i tomu se pridodaje slučaj posvemašnjega izostanka ekvivalentnosti. U našoj međujezičnoj raščlambi frazema mikrosistema biblijskih frazema talijanskoga i hrvatskoga

\footnotetext{
${ }^{94} \mathrm{Za}$ tu svrhu potrebno je jedno zasebno opsežno istraživanje koje bi rasvijetlilo općenito stilsku vrijednost poglavito frazeoloških jednakovrijednica u talijanskome i hrvatskome, pri čemu to ne moraju biti samo frazemi biblijskoga podrijetla.
} 
jezika ekvivalentnost ćemo podijeliti na potpunu, djelomičnu, čisto semantičku i nultu ekvivalentnost (usp. primjerice Henschel 1993; Földes 1997; Malá 1999 itd.). Prva tri tipa u biti su tipovi ekvivalentnosti, dok je četvrti nefrazeološka ekvivalentnost. Postoji dakle u ciljnome jeziku neko tumačenje toga frazema, ali ono nije frazeološko. ${ }^{95}$ Pri tome ćemo se ograničiti na usporedbu dvaju subsustava, ne tražeći moguće ekvivalente među drugim frazemima. S obzirom na to da je sinonimija u frazeologiji česta pojava, moglo bi se pronaći frazema koji pokazuju djelomičnu ekvivalentnost. Shematski prikazano ${ }^{96}$ to bi ovako izgledalo:

\begin{tabular}{|c|c|c|c|}
\hline $\begin{array}{c}\text { Tipovi } \\
\text { ekvivalentnosti }\end{array}$ & $\begin{array}{c}\text { Denotativno } \\
\text { značenje i stilska } \\
\text { vrijednost }\end{array}$ & Doslovno značenje & Struktura \\
\hline $\begin{array}{l}\text { 1. Potpuna } \\
\text { ekvivalentnost }\end{array}$ & + & + & + \\
\hline \multicolumn{4}{|c|}{ 2. Djelomična ekvivalentnost } \\
\hline 2.a. & + & + & * \\
\hline 2.b. & + & -97 & $*$ \\
\hline 2.c. & + & $* *$ & $* *$ \\
\hline $\begin{array}{l}\text { 3. Čisto } \\
\text { semantička } \\
\text { ekvivalentnost }\end{array}$ & + & -98 & - \\
\hline $\begin{array}{ll}\text { 4. } & \text { Nulta } \\
& \text { ekvivalentnost }\end{array}$ & - & - & - \\
\hline
\end{tabular}

\footnotetext{
${ }^{95}$ U ovome kontekstu valja spomenuti postojanje i frazeoloških lažnih prijatelja. Leksički lažni prijatelji ili parovi česta su pojava u supostavnim raščlambama leksika europskih jezika (usp. Ljubičić 2011). U okviru ovoga rada ne možemo se iscrpnije baviti ovim problemom premda smo naišli na nekoliko primjera u ovome mikrosustavu o kojima bi se moglo raspravljati barem kao o djelomičnim lažnim parovima.

${ }^{96}$ U shematskim prikazima slijedili smo uobičajene prikaze u kontrastivnim radovima na njemačkome jeziku koje smo prilagodili potrebama ovoga istraživanja (usp. primjerice Chrissou 2000, 139; Komenda Earle 2009, 71 - 78 itd.).

Znakovi imaju sljedeće značenje: a) + isto značenje; b) * isto ili malo različno značenje; c)** djelomično različno značenje; d) - različno značenje.

${ }^{97}$ U slučaju djelomične ekvivalentnosti ovoga tipa razlikuje se samo jedna glavna sastavnica.

${ }^{98}$ U slučaju čisto semantičke ekvivalentnosti zamjetna je razlika u više od jedne sastavnice.
} 
Pri izradbi tablica s jednakovrijednicama držali smo se sljedećih tipoloških konvencija:

1) Frazemi iz obaju jezika pisani su podebljano, primjerice: Torre di Babele.

2) Objašnjenje značenja stavljeno je u polunavodnike, primjerice: 'situacija u kojoj vlada zbunjenost; pomutnja'.

3) Doslovno značenje u slučaju djelomičnih ekvivalenata stavljeno je iza frazema, u zagradi nakon znaka jednakosti: (=...), a kod nulte ekvivalentnosti u poseban kvadratić iza znaka jednakosti: = ići u Emaus.

4) Izostavljive sastavnice napisane su u šiljastim (izlomljenim) zagradama: con tutti i crismi $<$ e sacrismi $>$.

5) Vidski parnjak u hrvatskome odvojen je kosom crtom, pri čemu se prvo navodi glagolski oblik svršenoga vida: baciti / bacati bisere (biserje) pred svinje.

6) Rekcija u obama jezicima pisana je kosim slovima: mettere in croce qualcuno.

7) Inačice su pisane u oblim zagradama: brat u Kristu (po Kristu). Jedino ako je bilo potrebno radi preglednosti inačice, osobito nesinonimske, pisane su iza skraćenice var., kako je i uobičajeno u talijanskim rječnicima, primjerice: chiudersi in una torre d'avorio (var. vivere in una torre d'avorio).

\subsubsection{Potpuna ekvivalentnost}

O potpunoj ekvivalentnost govorimo kada je posrijedi „konvergirajuće denotativno odnosno doslovno značenje, kongruentna struktura sastavnica i podudarna stilska vrijednost“ (Chrissou 2000, 141). Dakle, frazeološka jedinica ima ista morfosintaktička i leksičkosemantička obilježja u polaznome i ciljnome jeziku tako da se frazemi dvaju jezika mogu rabiti na isti način i raspolažu istim pragmatičkim potencijama. To podrazumijeva isto i denotativno i konotativno, emocionalno-ekspresivno i stilsko cjelokupno značenje, posvemašnju kongruentnost u slijedu sastavnica i frazemi imaju kao temelj identičnu sliku (usp. Zeman 2005, 308; Földes 1997, 118). 
Riječ je dakle o posvemašnjoj podudarnosti u bitnim vidovima frazema koji se opisuju: semantici, leksiku, sintaksi, slikovitosti i pragmatici (usp. Korhonen 1991, 123). Mogli bismo reći dakle da je riječ o formalnoj konvergenciji uz semantičku ekvivalenciju i istu sliku.

Taj oblik ekvivalentnosti u pravilu je i najrjeđi zbog „kulturno-semantičke nepodudarnosti“ (Földes 1997, 119) između nositelja značenja u polaznome i ciljnome jeziku. Premda je riječ o istome izvoru: Bibliji ili Svetome pismu svaki je narod na svoj način prihvaćao, tumačio i rabio te biblijske izraze. Različan zemljopisni položaj, isprepletenost jezika i politike, kulture i naslijeđa dovodi do različitih ishoda u nastanka frazema.

Sljedeći frazemi u talijanskome i hrvatskome mogu se držati jednakovrijednicama:

\begin{tabular}{|c|c|c|}
\hline $\begin{array}{c}\text { FRAZEM/ } \\
\text { TALIJANSKI }\end{array}$ & $\begin{array}{c}\text { FRAZEM/ } \\
\text { HRVATSKI }\end{array}$ & ZNAČENJE \\
\hline 1. l'alfa e l'omega & alfa i omega & $\begin{array}{c}\text { 'biti početak i svršetak } \\
\text { svega, iznimno važna osoba' }\end{array}$ \\
\hline 2. pomo d'Adamo & Adamova jabučica & $\begin{array}{c}\text { 'izbočenje na ljudskome } \\
\text { vratu vidljivo uglavnom u } \\
\text { muškaraca' }\end{array}$ \\
\hline 3. essere un angelo & biti anđeo & $\begin{array}{l}\text { 'biti osoba izuzetnoga } \\
\text { karaktera i dobrote' }\end{array}$ \\
\hline $\begin{array}{l}\text { 4. } \text { stirpe (razza, } \\
\text { progenie, figli) } \\
\text { d'Adamo }\end{array}$ & Adamsko koljeno & 'ljudski rod' \\
\hline 5. Agnello di Dio & Jaganjac Božji & $\begin{array}{l}\text { 'Isus u obličju žrtve } \\
\text { prikazane za spas } \\
\text { čovječanstva' }\end{array}$ \\
\hline 6. mite come un agnello & krotak kao janje & $\begin{array}{l}\text { 'biti krotka, blaga i } \\
\text { tolerantna osoba' }\end{array}$ \\
\hline 7. angelo custode & anđeo čuvar & $\begin{array}{l}\text { 'osoba koja podupire koga } \\
\text { materijalno ili savjetima, } \\
\text { koja se zalaže za drugoga' }\end{array}$ \\
\hline
\end{tabular}




\begin{tabular}{|c|c|c|}
\hline $\begin{array}{l}\text { 8. raccomandare l'anima } \\
\text { a Dio }\end{array}$ & preporučiti dušu Bogu & $\begin{array}{c}\text { 'pripraviti se za smrt, } \\
\text { primjerice u pogibeljnim } \\
\text { situacijama' }\end{array}$ \\
\hline 9. rendere l'anima a Dio & predati dušu Bogu & 'umrijeti' \\
\hline 10. anima dannata & prokleta duša & $\begin{array}{l}\text { 'prokletnik, prijetvorna i zla } \\
\text { osoba koja svojim } \\
\text { ponašanjem zaslužuje } \\
\text { vječno prokletstvo' }\end{array}$ \\
\hline 11. essere un anticristo & biti antikrist & $\begin{array}{l}\text { 'protivnik kršćanstva, čovjek } \\
\text { lišen bilo kakve čovječnosti' }\end{array}$ \\
\hline 12. Torre di Babele & $\begin{array}{c}\text { kula Babilonska } \\
\text { (Babilonska kula) }\end{array}$ & $\begin{array}{l}\text { 'situacija u kojoj vlada } \\
\text { zbunjenost; pomutnja' }\end{array}$ \\
\hline $\begin{array}{l}\text { 13. essere una } \\
\text { benedizione }\end{array}$ & biti blagoslov & $\begin{array}{c}\text { 'providonosna osoba ili } \\
\text { stvar' }\end{array}$ \\
\hline $\begin{array}{l}\text { 14. Bussate e vi sarà } \\
\text { aperto. }\end{array}$ & Kucajte i otvorit će vam se. & $\begin{array}{c}\text { 'onaj tko nešto traži i } \\
\text { zahtijeva upornošću može } \\
\text { postići neki cilj' }\end{array}$ \\
\hline $\begin{array}{l}\text { 15. segno (marchio) di } \\
\text { Caino }\end{array}$ & Kajinov znak (žig) & $\begin{array}{l}\text { 'žig kao simbol sramote } \\
\text { poradi bratoubojstva' }\end{array}$ \\
\hline 16. caldo d'inferno & paklena vrućina & 'nepodnošljiva žega' \\
\hline $\begin{array}{l}\text { 17. (bere) l'amaro calice } \\
\text { (var. bere il calice } \\
\text { d'amarezza) }\end{array}$ & $\begin{array}{c}\text { (piti) gorki kalež (var. piti } \\
\text { kalež gorčine) }\end{array}$ & $\begin{array}{l}\text { 'strpljivo podnositi } \\
\text { neugodnu situaciju' }\end{array}$ \\
\hline $\begin{array}{l}\text { 18. bere il calice fino alla } \\
\text { feccia }\end{array}$ & ispiti kalež do dna & $\begin{array}{l}\text { 'do kraja podnositi tešku } \\
\text { situaciju ili bezizlazje' }\end{array}$ \\
\hline $\begin{array}{l}\text { 19. essere un castigo di } \\
\text { Dio }\end{array}$ & biti Božja kazna & $\begin{array}{c}\text { 'situacija velike nesreće, } \\
\text { pandemije, rata; izrazito } \\
\text { zamorna i teška osoba' }\end{array}$ \\
\hline $\begin{array}{l}\text { 20. i < quattro }>\text { cavalieri } \\
\text { dell'Apocalisse }\end{array}$ & $\begin{array}{c}\text { jahači Apokalipse (<četiri }> \\
\text { jahača apokalipse) }\end{array}$ & $\begin{array}{l}\text { 'zloslutni jahači kao simbol } \\
\text { nedaća koje prate } \\
\text { čovječanstvo, ujedno i }\end{array}$ \\
\hline
\end{tabular}




\begin{tabular}{|c|c|c|}
\hline & & $\begin{array}{c}\text { prethodnici koji najavljuju } \\
\text { kraj svijeta' }\end{array}$ \\
\hline 21. fratello in Cristo & brat u Kristu (po Kristu) & $\begin{array}{c}\text { 'osobe povezane } \\
\text { vjeroispoviješću i } \\
\text { pripadnošću Crkvi koje tako } \\
\text { postaju braćom' }\end{array}$ \\
\hline 22. bacio di Giuda & Judin poljubac & 'izdaja' \\
\hline 23. essere un calvario & biti Kalvarija & $\begin{array}{c}\text { 'slijed nesreća koje koga } \\
\text { zadese, duga i mučna patnja' }\end{array}$ \\
\hline $\begin{array}{l}\text { 24. Il Signore ha qualcuno } \\
\text { chiamato a sé. }\end{array}$ & $\begin{array}{c}\text { Gospod je pozvao } \operatorname{kog} a \mathrm{k} \\
\text { sebi. }\end{array}$ & 'netko je preminuo' \\
\hline $\begin{array}{l}\text { 25. addormentarsi in } \\
\text { Cristo }\end{array}$ & usnuti u Kristu & 'umrijeti' \\
\hline 26. dormire in Cristo & počivati u Kristu & $\begin{array}{c}\text { 'osobe koje su preminule i za } \\
\text { koje se pretpostavlja da su } \\
\text { spašene' }\end{array}$ \\
\hline $\begin{array}{l}\text { 27. mettere in croce } \\
\text { qualcuno }\end{array}$ & $\begin{array}{c}\text { razapeti / razapinjati } \\
\text { (pribiti / pribijati) na križ } \\
k \text { koga }\end{array}$ & $\begin{array}{c}\text { 'javno optužiti koga, oštro } \\
\text { kritizirati koga' }\end{array}$ \\
\hline $\begin{array}{l}\text { 28. essere un colosso dai } \\
\text { piedi d'argilla }\end{array}$ & $\begin{array}{c}\text { biti div (kolos) na glinenim } \\
\text { nogama }\end{array}$ & $\begin{array}{l}\text { 'netko tko izvana pokazuje } \\
\text { veliku snagu i moć, ali to ne } \\
\text { počiva na dobrim temeljima' }\end{array}$ \\
\hline $\begin{array}{l}\text { 29. }<\text { fare }>\text { come Dio } \\
\text { comanda }\end{array}$ & $\begin{array}{c}<\text { uraditi }>\text { kako Bog } \\
\text { zapovijeda }\end{array}$ & 'kako valja, kako je ispravno' \\
\hline 30. essere un demonio & biti vrag & $\begin{array}{l}\text { 'biti stalno nemiran' (Kaže se } \\
\text { općenito za nestašnu djecu } \\
\text { koja stalno stvaraju } \\
\text { probleme.) }\end{array}$ \\
\hline $\begin{array}{l}\text { 31. dormire il sonno del } \\
\text { giusto }\end{array}$ & spavati snom pravednika & 'mirno spavati čiste savjesti' \\
\hline $\begin{array}{l}\text { 32. mandare qualcuno da } \\
\text { Erode a Pilato (da } \\
\text { Ponzio a Pilato) }\end{array}$ & $\begin{array}{c}\text { slati koga od Heroda } \\
\text { (Iruda) do Pilata (od } \\
\text { Poncija do Pilata) }\end{array}$ & $\begin{array}{l}\text { 'bespotrebno slati koga od } \\
\text { jedne do druge osobe, s } \\
\text { jednoga mjesta na drugo' }\end{array}$ \\
\hline
\end{tabular}




\begin{tabular}{|c|c|c|}
\hline $\begin{array}{l}\text { 33. cancellare qualcuno } \\
\text { dalla faccia della terra }\end{array}$ & zbrisati koga s lica zemlje & $\begin{array}{c}\text { 'uništiti } k o g a, \text { iskorijeniti } \\
\text { što' }\end{array}$ \\
\hline $\begin{array}{l}\text { 34. sparire dalla faccia } \\
\text { della terra }\end{array}$ & $\begin{array}{c}\text { iščeznuti (nestati) s lica } \\
\text { zemlje }\end{array}$ & 'potpuno nestati, iščeznuti' \\
\hline 35. essere un fariseo & biti farizej & $\begin{array}{c}\text { 'biti dvolična osoba, } \\
\text { licemjer' }\end{array}$ \\
\hline 36. Figlio di Dio & Sin Božji & 'za kršćane Isus Krist' \\
\hline 37. Figlio dell'uomo & Sin Čovječji & 'naziv za Isusa Krista' \\
\hline 38. figliol prodigo & $\begin{array}{c}\text { razmetni (rasipni, } \\
\text { izgubljeni, bludni) sin }\end{array}$ & $\begin{array}{l}\text { 'osoba koja je zabludjela i } \\
\text { koja je na krivome putu' }\end{array}$ \\
\hline 39. essere un filisteo & biti filistar & $\begin{array}{l}\text { 'biti konzervativan i } \\
\text { reakcionaran; biti } \\
\text { uskogrudna i zatucana } \\
\text { osoba' }\end{array}$ \\
\hline 40. flagello di Dio & bič Božji & $\begin{array}{l}\text { 'prirodna nesreća velikih } \\
\text { razmjera; osoba koja je } \\
\text { prouzročila ili čini mnoga } \\
\text { zla' }\end{array}$ \\
\hline 41. frutto proibito & zabranjeno voće & $\begin{array}{c}\text { 'neka stvar ili ugoda koja je } \\
\text { zabranjena' }\end{array}$ \\
\hline 42. forte come Sansone & jak kao Samson & 'biti osoba izuzetne snage' \\
\hline $\begin{array}{l}\text { 43. porgere l'altra } \\
\text { guancia }\end{array}$ & okrenuti drugi obraz & $\begin{array}{l}\text { 'oprostiti uvredu ili } \\
\text { nepravdu i tražiti pomirbu' }\end{array}$ \\
\hline $\begin{array}{r}\text { 44. essere immagine e } \\
\text { somiglianza di Dio }\end{array}$ & biti slika i prilika Božja & $\begin{array}{l}\text { 'svaki čovjek jest Božje } \\
\text { stvorenje što mu daje } \\
\text { dostojanstvo Božjega } \\
\text { posinstva' }\end{array}$ \\
\hline $\begin{array}{l}\text { 45. lavarsi le mani }<\text { come } \\
\text { Pilato }>\end{array}$ & $\begin{array}{c}\text { oprati / prati (umiti) ruke } \\
\text { < kao Pilat }>\end{array}$ & $\begin{array}{l}\text { 'ne prihvaćati odgovornost, } \\
\text { prepustiti drugima da } \\
\text { donose odluku' (Kao što je } \\
\text { to učinio Pilat.) }\end{array}$ \\
\hline
\end{tabular}




\begin{tabular}{|c|c|c|}
\hline $\begin{array}{l}\text { 46. lavarsene le mani di } \\
\text { qualcosa }\end{array}$ & oprati / prati ruke od čega & $\begin{array}{c}\text { 'odbacivati odgovornost, } \\
\text { prepustiti drugima da } \\
\text { odlučuju' }\end{array}$ \\
\hline $\begin{array}{l}\text { 47. aspettare }<\text { che piova }> \\
\text { la manna dal cielo }\end{array}$ & $\begin{array}{c}\text { čekati }<\text { da padne mana }> \\
\text { manu s neba }\end{array}$ & $\begin{array}{c}\text { 'pasivno čekati da se riješi } \\
\text { neka situacija' }\end{array}$ \\
\hline $\begin{array}{l}\text { 48. essere una manna } \\
\text { < dal cielo }>\end{array}$ & biti mana $<$ nebeska $>$ & $\begin{array}{c}\text { 'biti sreća, rješenje nekoga } \\
\text { problema' }\end{array}$ \\
\hline 49. spostare le montagne & premještati brda (planine) & $\begin{array}{c}\text { 'činiti velike napore, uspjeti } \\
\text { u teškim pothvatima' }\end{array}$ \\
\hline $\begin{array}{l}\text { 50. lasciare che i morti } \\
\text { seppelliscano i morti }\end{array}$ & $\begin{array}{c}\text { ostaviti (pustiti) mrtve da } \\
\text { pokapaju (sahranjuju) } \\
\text { mrtve }\end{array}$ & $\begin{array}{c}\text { 'ne gubiti vrijeme s } \\
\text { nevažnim stvarima i } \\
\text { pozornost usmjeriti na važne } \\
\text { odluke i ciljeve' }\end{array}$ \\
\hline $\begin{array}{l}\text { 51. Occhio per occhio, } \\
<\text { dente per dente> } \\
\text { (var. < occhio per } \\
\text { occhio>, dente per } \\
\text { dente) }\end{array}$ & $\begin{array}{c}\text { Oko za oko, }<\text { zub za zub> } \\
(\text { var. }<\text { oko za oko }>\text {, zub za } \\
\text { zub) }\end{array}$ & 'načelo osvete' \\
\hline 52. la pace eterna & vječni pokoj & $\begin{array}{l}\text { 'smrt, posebice za one koji } \\
\text { su živjeli bogobojazno i za } \\
\text { koje se pretpostavlja da su } \\
\text { spašeni' }\end{array}$ \\
\hline $\begin{array}{l}\text { 53. riportare (ricondurre) } \\
\text { all'ovile qualcuno }\end{array}$ & vratiti u ovčinjak koga & $\begin{array}{c}\text { 'vratiti koga na pravi put, } \\
\text { uvjeriti ga da napusti grješan } \\
\text { život, poročnost' }\end{array}$ \\
\hline 54. tornare all'ovile & vratiti se u ovčinjak & $\begin{array}{c}\text { 'vratiti se obitelji ili vjerskoj } \\
\text { zajednici od koje se netko } \\
\text { udaljio' }\end{array}$ \\
\hline 55. servire due padroni & služiti dvojici gospodara & $\begin{array}{l}\text { 'služiti osobama, pokretima } \\
\text { ili idejama koje su oprječne, } \\
\text { nerijetko radi materijalnoga }\end{array}$ \\
\hline
\end{tabular}




\begin{tabular}{|c|c|c|}
\hline & & $\begin{array}{c}\text { probitka i uspjeha bez } \\
\text { ikakve lojalnosti' }\end{array}$ \\
\hline 56. Parola di Dio & Riječ Božja & $\begin{array}{l}\text { 'svetopisamski tekstovi i } \\
\text { homilije koje ih tumače' }\end{array}$ \\
\hline 57. il peccato mortale & smrtni grijeh & $\begin{array}{c}\text { 'težak prijestup, neoprostiva } \\
\text { pogrješka' }\end{array}$ \\
\hline 58. il peccato originale & istočni grijeh & $\begin{array}{c}\text { 'najveći grijeh, neoprostiva } \\
\text { pogrješka' }\end{array}$ \\
\hline $\begin{array}{l}\text { 59. essere una pecora } \\
\text { (pecorella) smarrita }\end{array}$ & $\begin{array}{l}\text { biti izgubljena (zalutala, } \\
\text { zabludjela) ovca (ovčica) }\end{array}$ & $\begin{array}{c}\text { 'biti grješnik ili osoba koja je } \\
\text { izgubila vjeru' }\end{array}$ \\
\hline $\begin{array}{l}\text { 60. essere la pietra } \\
\text { angolare }\end{array}$ & biti kamen zaglavni & $\begin{array}{c}\text { 'biti glavni dio čega, temelj } \\
\text { neke situacije ili zdanja' }\end{array}$ \\
\hline 61. pietra dello scandalo & kamen spoticanja & 'uzrok svađa, polemika i sl.' \\
\hline 62. Popolo eletto & Izabrani narod & $\begin{array}{c}\text { 'Izrael, Židovi; općenito: } \\
\text { ljudi koji imaju neke } \\
\text { povlastice' }\end{array}$ \\
\hline 63. sapienza di Salomone & Salomonova mudrost & 'velika mudrost i razboritost' \\
\hline $\begin{array}{l}\text { 64. giudizio di Salomone } \\
\text { (salomonico) }\end{array}$ & $\begin{array}{c}\text { salamonsko (salamunsko, } \\
\text { solomunsko) rješenje } \\
\text { (presuda) }\end{array}$ & $\begin{array}{l}\text { 'mudro, pravedno i } \\
\text { dovitljivo rješenje' }\end{array}$ \\
\hline 65. Sancta sanctorum ${ }^{99}$ & $\begin{array}{c}\text { Svetinja nad svetinjama } \\
\text { (Sancta sanctorum) }\end{array}$ & $\begin{array}{c}\text { 'privilegirano mjesto } \\
\text { kojemu imaju pristup samo } \\
\text { odabrani' }\end{array}$ \\
\hline $\begin{array}{l}\text { 66. essere un sepolcro } \\
\text { imbiancato }\end{array}$ & $\begin{array}{c}\text { biti okrečen (obijeljen) } \\
\text { grob }\end{array}$ & 'biti licemjer, farizej’ \\
\hline 67. l'antico serpente & stara zmija & ‘vrag, đavao' \\
\hline
\end{tabular}

\footnotetext{
${ }^{99}$ Sancta sanctorum ili Svetinja nad svetinjama predstavljala je u Starome zavjetu najvažniji dio Jeruzalemskoga hrama. Tim se pojmom označava dio oko oltara, odnosno oko Svetohraništa u katoličkim crkvama te papinska privatna kapelica koja je smještena na prvome katu negdašnjega drevnog patrijarhata u Svetome Ivanu Laternskom. Ovaj smo izraz uvrstili samo u njegovu značenju u općemu jeziku. usp. $<$ http://www.treccani.it/vocabolario/sancta-sanctorum/> (3.8.2020.).
} 


\begin{tabular}{|c|c|c|}
\hline $\begin{array}{l}\text { 68. }<\text { Niente di nuovo }> \\
\text { sotto il sole. }\end{array}$ & $<$ Ništa novo $>$ pod suncem. & $\begin{array}{c}\text { 'vječno ponavljanje događaja } \\
\text { u povijesti svijeta' }\end{array}$ \\
\hline $\begin{array}{l}\text { 69. aprire la porta del } \\
\text { paradiso }\end{array}$ & otvoriti rajska vrata & $\begin{array}{c}\text { 'omogućiti čije vječno } \\
\text { spasenje' }\end{array}$ \\
\hline 70. Terra promessa & Obećana zemlja & $\begin{array}{c}\text { 'zemlja bogatstva i izobilja; } \\
\text { mjesto beskrajne sreće' }\end{array}$ \\
\hline 71. Sodoma e Gomorra & Sodoma i Gomora & $\begin{array}{l}\text { 'mjesto izopačenosti, } \\
\text { poglavito spolne' }\end{array}$ \\
\hline $\begin{array}{l}\text { 72. chiudersi in una torre } \\
\text { d'avorio (var. vivere } \\
\text { in una torre d'avorio) }\end{array}$ & $\begin{array}{c}\text { zatvoriti se u kulu od } \\
\text { slonove kosti (slonovače) } \\
\text { (var. živjeti u kuli od } \\
\text { slonove kosti) }\end{array}$ & $\begin{array}{l}\text { 'izdvojiti se na samotno } \\
\text { mjesto radi razmatranja i } \\
\text { stvaranja' }\end{array}$ \\
\hline 73. il primo uomo & prvi čovjek & $\begin{array}{l}\text { 'za kršćane i židove Adam, } \\
\text { prvi čovjek kojega je Bog } \\
\text { stvorio skupa s njegovom } \\
\text { ženom Evom' }\end{array}$ \\
\hline 74. uomo nuovo & novi čovjek & $\begin{array}{l}\text { 'za kršćane Isus Krist i po } \\
\text { njemu svaki čovjek po } \\
\text { krštenju opran od istočnoga } \\
\text { grijeha' }\end{array}$ \\
\hline 75. Vade retro Satana! & Odlazi Sotono! & $\begin{array}{l}\text { 'uzvik koji se upućuje komu } \\
\text { koga se želi udaljiti ili kada } \\
\text { se odbacuje prijedlog koji } \\
\text { može biti primamljiv' }\end{array}$ \\
\hline 76. la vigna del Signore & vinograd Gospodnji & 'Crkva na zemlji' \\
\hline 77. la vita eterna & život vječni & $\begin{array}{c}\text { 'za kršćane beskrajna radost } \\
\text { i sreća za one koji zasluže } \\
\text { raj' }\end{array}$ \\
\hline 78. adorare il vitello d'oro & klanjati se zlatnomu teletu & $\begin{array}{c}\text { 'misliti samo na materijalna } \\
\text { bogatstva i novac' }\end{array}$ \\
\hline 79. volontà di Dio & Božja volja & $\begin{array}{c}\text { 'nešto što se mora dogoditi, } \\
\text { nešto nepredvidljivo' }\end{array}$ \\
\hline
\end{tabular}




\begin{tabular}{|l|c|c|}
\hline 80. Vox populi, vox dei. & Glas naroda, glas Božji. & $\begin{array}{c}\text { 'jednodušnost naroda } u \\
\text { prihvaćanju neke istine drži }\end{array}$ \\
& & se nebeskom potvrdom \\
& & istinitosti' \\
\hline
\end{tabular}

Pri određivanju jednakovrijednica nismo uzimali u obzir neke malene razlike u dvama jezicima, primjerice:

- u broju sastavnica, osobito nepunoznačnica:

a) Besprijedložni dativ u hrvatskome i neizravni objekt s prijedlogom $a$ u talijanskome jer talijanski jezik ne poznaje nominalnu fleksiju i time se dativ u hrvatskome ponajčešće izriče prijedlogom a+imenica (zamjenica itd.):

raccomandare l'anima a Dio - preporučiti dušu Bogu ili

rendere l'anima a Dio - predati dušu Bogu

b) Zbog uporabe određenoga ili neodređenoga člana u talijanskome koji ne postoji $\mathrm{u}$ hrvatskome:

essere un Giuda - biti Juda

- posvojni pridjev u hrvatskome:

Stirpe d'Adamo (razza, progenie, figli d'Adamo) - adamsko koljeno i u drugim primjerima

- različnu glagolsku rekciju u dvama jezicima:

Servire due padroni - služiti dvojici gospodara.

U obzir nismo uzeli postojanje inačica u jednome jeziku i nepostojanje u drugome. Bilo je primjera u obama jezicima. Problem je bio i pri određivanju kanonskoga oblika frazema i njegovih inačica jer su se u tome izvori razlikovali. Bez obzira na to je li u talijanskome ili u hrvatskome jedan oblik bio naveden kao kanonski, a drugi kao inačica, uzimali smo to kao ekvivalent s oblikom u talijanskome i obratno prema onome rječniku koji navodi ekvivalent 
kao kanonski oblik. Ako neke inačice uključuju istoznačnice ili bliskoznačnice u jednome jeziku, a u drugome ne postoje, a te inačice ne mijenjaju bitno značenje frazema, i te smo primjere uključili u potpunu ekvivalentnost. U slučaju da u inačici dolazi do promjena u broju sastavnica ili da se razlikuje glavna leksička sastavnica, uključili smo taj primjer u djelomičnu ekvivalentnost.

\subsubsection{Djelomična ekvivalentnost}

O djelomičnoj pak ekvivalentnosti govorimo kada je isto cjelokupno značenje i semantički model, međutim zamjetne su razlike, odnosno nepodudarnost u broju sastavnica. Chrissou $(2000,140)$ s time u svezi govori o istome denotativnom značenju kao minimalnoj pretpostavci međujezične usporedbe uz različnu distribuciju glede ostalih kriterija. U slučaju djelomične ekvivalentnosti obično se određuju podtipovi, pri čemu su posrijedi najčešće razlike u doslovnome značenju, strukturi ili stilskoj označenosti. Podtipove kadšto nije lako formulirati i ovise o onomu što se istražuje kao i o jezicima koji se uspoređuju.

Kako se u djelomičnu ekvivalentnost uključuju frazemi u kojima postoje gramatičke, leksičke pa čak i malene semantičke razlike, neki frazeolozi dijele ih u tri područja:

a) djelomičnu ekvivalentnost s gramatičkom specifičnošću (i uglavnom sa slikovnom ekvivalentnošću)

b) djelomičnu ekvivalentnost sa semantičkom specifičnošću (i uglavnom sa slikovnom ekvivalentnošću) i

c) djelomičnu ekvivalentnost s leksičko-gramatičkom specifičnošću (i funkcionalnom slikovnom ekvivalentnošću) (usp. Komenda-Earle 2009, 70).

Premda postoje i druge podjele djelomične ekvivalencije, ${ }^{100}$ ovu držimo najprikladnijom za našu raščlambu.

U usporedbi frazema dvaju ili više jezika djelomična ekvivalentnost uglavnom je najzastupljenija, posebice kad govorimo o usporedbi europskih jezika koji, onkraj genetske

\footnotetext{
${ }^{100}$ Postoje različne podjele djelomične ekvivalencije. Regina Hessky u usporedbi njemačkih i mađarskih frazema razlikuje 9 skupina djelomične ekvivalencije (usp. Hessky 1987).
} 
srodnosti bilo unutar iste jezične porodice, bilo indoeuropske nadporodice, uključujući i sve one jezike koji nisu indoeuropski, zbog svoje zajedničke povijesti, pripadanja istomu ili sličnomu kulturnom krugu te trajnih međusobnih dodira idu u smjeru sve veće jezične $i$ frazeološke konvergencije (usp. Ljubičić 2011, 176).

a) Sljedeći frazemi biblijskoga podrijetla imaju isto cjelokupno značenje, međutim postoje razlike u morfosintaksi:

\begin{tabular}{|c|c|c|c|}
\hline $\begin{array}{c}\text { FRAZEM/ } \\
\text { TALIJANSKI }\end{array}$ & $\begin{array}{c}\text { FRAZEM/ } \\
\text { HRVATSKI }\end{array}$ & ZNAČENJE & RAZLIKA \\
\hline $\begin{array}{l}\text { 81. (essere) in } \\
\text { costume } \\
\text { adamitico } \\
\text { (evitico) } \\
\text { (= biti u } \\
\text { adamovskome } \\
\text { (evinovskome) } \\
\text { kostimu) }\end{array}$ & $\begin{array}{l}\text { (biti) u Adamovu } \\
\text { (Evinu) kostimu }\end{array}$ & 'biti gol' & $\begin{array}{c}\text { morfološka } \\
\text { (različite vrste } \\
\text { posvojnih pridjeva } \\
\text { i time i različita } \\
\text { grafija) }\end{array}$ \\
\hline $\begin{array}{l}\text { 82. essere una } \\
\text { Babele } \\
\text { (Babilonia) } \\
\text { (= biti } \\
\text { Babilon) }\end{array}$ & $\begin{array}{l}\text { biti (naći se) u } \\
\text { Babilonu }\end{array}$ & $\begin{array}{l}\text { 'mjesto na } \\
\text { kojemu vlada } \\
\text { nered, pomutnja i } \\
\text { nerazumijevanje } \\
\text { svake vrste' }\end{array}$ & $\begin{array}{l}\text { sintaktička (glavna } \\
\text { leksička } \\
\text { sastavnica u } \\
\text { talijanskome je } \\
\text { dijelom } \\
\text { imenskoga } \\
\text { predikata, a u } \\
\text { hrvatskome } \\
\text { dijelom } \\
\text { prijedložnoga } \\
\text { izraza) }\end{array}$ \\
\hline $\begin{array}{l}\text { 83. (essere) la voce } \\
\text { di uno che } \\
\text { grida nel }\end{array}$ & $\begin{array}{l}\text { (biti) glas } \\
\text { vapijućega u } \\
\text { pustinji }\end{array}$ & $\begin{array}{l}\text { 'glas osobe, } \\
\text { proroka koji } \\
\text { opominje na }\end{array}$ & $\begin{array}{l}\text { morfosintaktička } \\
\text { (glagolski prilog } \\
\text { sadašnji u }\end{array}$ \\
\hline
\end{tabular}




\begin{tabular}{|c|c|c|c|}
\hline $\begin{array}{l}\text { deserto) (= glas } \\
\text { jednoga koji viče } \\
\text { (vapije) u } \\
\text { pustinji) }\end{array}$ & & $\begin{array}{l}\text { dolazak neke } \\
\text { nesreće, a kojega } \\
\text { nitko ne sluša’ }\end{array}$ & $\begin{array}{l}\text { hrvatskome; } \\
\text { odnosna rečenica } \\
\text { u talijanskome) }\end{array}$ \\
\hline $\begin{array}{l}\text { 84. essere atteso } \\
\text { come il Messia } \\
\text { (= biti } \\
\text { iščekivan kao } \\
\text { Mesija) }\end{array}$ & $\begin{array}{l}\text { čekati kao } \\
\text { Mesiju koga }\end{array}$ & $\begin{array}{l}\text { 'dugo čekati } \\
\text { koga, iščekivati } \\
\text { koga kao } \\
\text { spasitelja' }\end{array}$ & $\begin{array}{l}\text { sintaktička } \\
\text { (pasivna } \\
\text { konstrukcija u } \\
\text { talijanskome, } \\
\text { aktivna u } \\
\text { hrvatskome) }\end{array}$ \\
\hline $\begin{array}{r}\text { 85. paradiso } \\
\text { terrestre } \\
(=\text { raj } \\
\text { zemaljski })\end{array}$ & $\begin{array}{l}\text { raj zemaljski (na } \\
\text { zemlji) }\end{array}$ & $\begin{array}{l}\text { 'prekrasno } \\
\text { mjesto, mjesto } \\
\text { bogato prirodnim } \\
\text { ljepotama i gdje } \\
\text { se živi u izobilju' }\end{array}$ & $\begin{array}{l}\text { sintaktička } \\
\text { (pridjev u } \\
\text { talijanskome, } \\
\text { pridjev ili } \\
\text { prijedložni izraz u } \\
\text { hrvatskome) }\end{array}$ \\
\hline
\end{tabular}

b) Sljedeći frazemi imaju isto cjelokupno značenje, ali postoji razlika u leksičkim sastavnicama:

\begin{tabular}{|c|c|c|c|}
\hline $\begin{array}{l}\text { FRAZEM/ } \\
\text { TALIJANSKI }\end{array}$ & $\begin{array}{l}\text { FRAZEM/ } \\
\text { HRVATSKI }\end{array}$ & ZNAČENJE & RAZLIKA \\
\hline 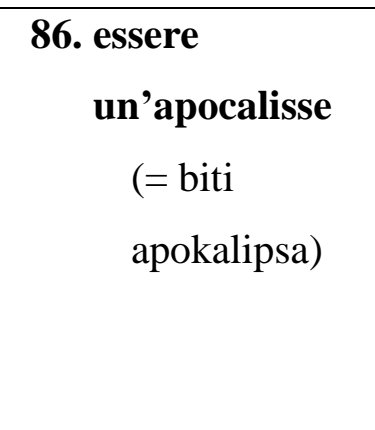 & (biti) apokalipsa & $\begin{array}{l}\text { 'vrijeme velikoga } \\
\text { nemira i pomutnje } \\
\text { koju prate često i } \\
\text { atmosferske } \\
\text { pojave, potresi, } \\
\text { ratovi itd.' }\end{array}$ & $\begin{array}{l}\text { leksička (u } \\
\text { hrvatskome je } \\
\text { uporaba glagola } \\
\text { biti uglavnom } \\
\text { fakultativna) }\end{array}$ \\
\hline $\begin{array}{l}\text { 87. cominciare da } \\
\text { Adamo ed Eva } \\
\text { (= početi od } \\
\text { Adama i Eve) }\end{array}$ & $\begin{array}{l}<\text { početi }>\text { od } \\
\text { Adama }<\text { i Eve }>\end{array}$ & $\begin{array}{l}\text { 'pričati naširoko, } \\
\text { iscrpno i potanko } \\
\text { o nekoj temi' }\end{array}$ & $\begin{array}{l}\text { leksička (u } \\
\text { hrvatskome se } \\
\text { dvije sastavnice } \\
\text { mogu izostaviti, }\end{array}$ \\
\hline
\end{tabular}




\begin{tabular}{|c|c|c|c|}
\hline & & & $\begin{array}{l}\text { u talijanskome su } \\
\text { obvezatne) }\end{array}$ \\
\hline $\begin{array}{l}\text { 88. essere il capro } \\
\text { espiatorio } \\
\text { (= biti žrtveni } \\
\text { jarac) }\end{array}$ & $\begin{array}{l}\text { biti žrtveni jarac } \\
\text { (̌̌rtveno janje) }\end{array}$ & $\begin{array}{l}\text { 'biti osoba na koju } \\
\text { se svaljuju krivnje } \\
\text { drugih ljudi' }\end{array}$ & $\begin{array}{l}\text { leksička } \\
\text { (frazemska } \\
\text { inačica u } \\
\text { hrvatskome } \\
\text { uključuje drugu } \\
\text { životinju kao } \\
\text { glavnu leksičku } \\
\text { sastavnicu) }\end{array}$ \\
\hline $\begin{array}{r}\text { 89. essere un corpo } \\
\text { e un'anima sola }\end{array}$ & $\begin{array}{l}\text { biti jedno tijelo i } \\
\text { jedna duša }\end{array}$ & $\begin{array}{l}\text { 'biti u prijateljstvu } \\
\text { s kime; živjeti u } \\
\text { slozi' }\end{array}$ & $\begin{array}{l}\text { leksička }(\mathrm{u} \\
\text { talijanskome se } \\
\text { rabi pridjev } \\
\text { solo/sola) }{ }^{101}\end{array}$ \\
\hline $\begin{array}{l}\text { 90. abbracciare la } \\
\text { <propria }>\text { croce } \\
(=\text { zagrliti } \\
\quad \text { < vlastiti }>\text { križ })\end{array}$ & $\begin{array}{l}\text { zagrliti vlastiti } \\
\text { (svoj) križ }\end{array}$ & $\begin{array}{l}\text { 'ponizno prihvatiti } \\
\text { sudbinu, muke i } \\
\text { patnje i strpljivo } \\
\text { ih podnositi' }\end{array}$ & $\begin{array}{l}\text { leksička } \\
\text { (u talijanskome } \\
\text { je pridjev } \\
\text { fakultativan, a u } \\
\text { hrvatskome } \\
\text { zamjenjiv } \\
\text { povratno- } \\
\text { posvojnom } \\
\text { zamjenicom) }\end{array}$ \\
\hline $\begin{array}{l}\text { 91. portare la } \\
\text { <propria }>\text { croce }\end{array}$ & $\begin{array}{l}\text { nositi (imati) } \\
\text { svoj križ }\end{array}$ & $\begin{array}{l}\text { 'mirno prihvaćati } \\
\text { životne nedaće i } \\
\text { trpljenja' }\end{array}$ & $\begin{array}{l}\text { leksička (u } \\
\text { talijanskome je } \\
\text { pridjev }\end{array}$ \\
\hline
\end{tabular}

${ }^{101} \mathrm{U}$ ovome slučaju moglo bi se porazmisliti je li se porabom pridjeva solo/sola nakon imenice s neodređenim članom un/una izreklo upravo ono što u hrvatskome izriče uporaba glavnoga broja jedan/jedna/jedno, međutim, u svakome slučaju riječ je o nepodudarnosti u broju sastavnica i to se ne može svrstati u temeljne strukturne razlike dvaju jezika. Ne isključujemo pak ni drukčije rješenje. 


\begin{tabular}{|c|c|c|c|}
\hline $\begin{array}{l}(=\text { nositi } \\
<\text { vlastiti }>\text { križ })\end{array}$ & & & $\begin{array}{l}\text { fakultativan, a u } \\
\text { hrvatskome } \\
\text { zamjenjiv } \\
\text { povratno- } \\
\text { posvojnom } \\
\text { zamjenicom) }\end{array}$ \\
\hline $\begin{array}{l}\text { 92. brutto come un } \\
\text { demonio (come } \\
\text { il diavolo) } \\
\text { (= ružan kao } \\
\text { demon (kao } \\
\text { vrag)) }\end{array}$ & ružan ko vrag & $\begin{array}{l}\text { 'iznimno ružna } \\
\text { osoba' }\end{array}$ & $\begin{array}{l}\text { leksička (u } \\
\text { hrvatskome se ne } \\
\text { rabi pojam } \\
\text { demon koji je } \\
\text { većma teološki i } \\
\text { stilski različan } \\
\text { od riječi vrag ili } \\
\text { u dijalektima } \\
\text { đavao) }\end{array}$ \\
\hline $\begin{array}{l}\text { 93. essere un Eden } \\
\text { (var. giardino } \\
\text { dell'Eden; } \\
\text { paradiso } \\
\text { terrestre) } \\
\text { (= biti Eden } \\
\text { (var. vrt Eden; } \\
\text { raj zemaljski)) }\end{array}$ & $\begin{array}{l}<\text { biti> raj } \\
\text { zemaljski }\end{array}$ & $\begin{array}{l}\text { 'mjesto iznimne } \\
\text { ljepote i } \\
\text { blagostanja' }\end{array}$ & $\begin{array}{l}\text { leksička (u } \\
\text { talijanskome se } \\
\text { rabi biblijski } \\
\text { naziv za raj } \\
\text { zemaljski te } \\
\text { inačica s } \\
\text { nazivom vrt, a u } \\
\text { hrvatskome } \\
\text { postoji inačica } \\
\text { bez glagola biti) }\end{array}$ \\
\hline $\begin{array}{l}\text { 94. vivere in un } \\
\text { Eden } \\
\text { (= živjeti u } \\
\text { Edenu })\end{array}$ & $\begin{array}{l}\text { živjeti u raju } \\
\text { zemaljskome } \\
\text { (kao u raju) }\end{array}$ & $\begin{array}{l}\text { 'živjeti u mjestu } \\
\text { beskrajne ljepote; } \\
\text { živjeti sretno i } \\
\text { radosno' }\end{array}$ & $\begin{array}{l}\text { leksička (u } \\
\text { talijanskome se } \\
\text { rabi biblijski } \\
\text { naziv za raj } \\
\text { zemaljski, a u }\end{array}$ \\
\hline
\end{tabular}




\begin{tabular}{|c|c|c|c|}
\hline & & & $\begin{array}{l}\text { hrvatskome } \\
\text { postoji inačica } \\
\text { koja je } \\
\text { komparativni } \\
\text { frazem) }\end{array}$ \\
\hline $\begin{array}{l}\text { 95. essere la fine del } \\
\text { mondo } \\
\quad(=\text { biti kraj } \\
\text { svijeta })\end{array}$ & $\begin{array}{l}\text { biti smak } \\
\text { svijeta }^{102}\end{array}$ & $\begin{array}{l}\text { 'strašan događaj } \\
\text { koji izaziva veliku } \\
\text { pomutnju i kaos' } \\
\text { (Ta pomutnja } \\
\text { podsjeća na kraj } \\
\text { svijeta } \\
\text { nagoviješten u } \\
\text { Svetome pismu.) }\end{array}$ & $\begin{array}{l}\text { leksička (u } \\
\text { hrvatskome se } \\
\text { rabi riječ smak } \\
\text { premda postoji i } \\
\text { izraz kraj svijeta) }\end{array}$ \\
\hline $\begin{array}{l}\text { 96. il fuoco } \\
\text { eterno }^{103} \\
\text { (= vječna } \\
\text { vatra })\end{array}$ & oganj neugasivi & $\begin{array}{l}\text { 'vatra u paklu i } \\
\text { vječna kazna za } \\
\text { nepokajane } \\
\text { grješnike' }\end{array}$ & $\begin{array}{l}\text { leksička (u } \\
\text { hrvatskome rabi } \\
\text { se drukčiji } \\
\text { pridjev) }\end{array}$ \\
\hline $\begin{array}{l}\text { 97. le tenebre eterne } \\
\quad(=\text { vječne } \\
\text { tmine })\end{array}$ & $\begin{array}{l}\text { vječno } \\
\text { prokletstvo } \\
\text { (vječne muke) }\end{array}$ & 'pakao' & $\begin{array}{l}\text { leksička (u } \\
\text { hrvatskome se } \\
\text { rabe dvije } \\
\text { imenice } \\
\text { drukčijega } \\
\text { značenja) }\end{array}$ \\
\hline $\begin{array}{l}\text { 98. lupo in veste } \\
\text { d'agnello } \\
\text { (= vuk u } \\
\text { janjećoj odori) }\end{array}$ & $\begin{array}{l}<\text { vuk }>\text { u } \\
\text { janjećoj }{ }^{104} \text { koži }\end{array}$ & $\begin{array}{l}\text { 'zla i prijetvorna } \\
\text { osoba koja krije } \\
\text { pakosne nakane } \\
\text { prikazujući se } \\
\text { blagom i } \\
\text { dobronamjernom' }\end{array}$ & $\begin{array}{l}\text { leksička (u } \\
\text { hrvatskome je } \\
\text { sastavnica } v u k \\
\text { fakultativna, a } \\
\text { rabi se imenica } \\
\text { drukčijega }\end{array}$ \\
\hline
\end{tabular}

\footnotetext{
${ }^{102} \mathrm{U}$ obama jezicima često se rabi i niječni oblik.

${ }^{103}$ Vječna vatra u hrvatskome ima posve drukčije značenje i ovaj je primjer dobar kandidat za raščlambu o frazeološkim lažnim parovima.

${ }^{104}$ Usp. $<$ http://ihjj.hr/kolokacije/search/?q=vuk\&search_type=basic\&page=2> (3.4.2021.).
} 


\begin{tabular}{|c|c|c|c|}
\hline & & & $\begin{array}{l}\text { značenja od tal. } \\
\text { veste) }\end{array}$ \\
\hline $\begin{array}{l}\text { 99. voce nel deserto } \\
\begin{array}{l}(=\text { glas } \mathrm{u} \\
\text { pustinji })\end{array}\end{array}$ & $\begin{array}{l}\text { propovijed u } \\
\text { pustinji }\end{array}$ & $\begin{array}{l}\text { 'riječi, savjeti ili } \\
\text { prijekori koje } \\
\text { nitko ne sluša. } \\
\text { Odnosi se i na } \\
\text { ideje koje nemaju } \\
\text { sljedbenike' }\end{array}$ & $\begin{array}{l}\text { leksička (u } \\
\text { hrvatskome se } \\
\text { rabi imenica } \\
\text { propovijed koja } \\
\text { nije prijevodni } \\
\text { ekvivalent tal. } \\
\text { imenici voce) }\end{array}$ \\
\hline
\end{tabular}

c) Sljedeći frazemi biblijskoga podrijetla imaju isto cjelokupno značenje, međutim postoje razlike i u morfologiji i sintaksi ili u leksičkim sastavnicama:

\begin{tabular}{|c|c|c|c|}
\hline $\begin{array}{l}\text { FRAZEM/ } \\
\text { TALIJANSKI }\end{array}$ & $\begin{array}{l}\text { FRAZEM/ } \\
\text { HRVATSKI }\end{array}$ & ZNAČENJE & RAZLIKA \\
\hline $\begin{array}{l}\text { 100. essere (mite } \\
\text { come) un } \\
\text { agnello (var. } \\
\text { fare l'agnello) } \\
\text { (= biti (krotak } \\
\text { kao) janje (var. } \\
\text { biti janje)) }\end{array}$ & $\begin{array}{l}\text { biti krotak kao } \\
\text { janje }\end{array}$ & $\begin{array}{l}\text { 'biti osoba } \\
\text { izrazito blagoga } \\
\text { karaktera' }\end{array}$ & $\begin{array}{l}\text { sintaktička i } \\
\text { leksička }\end{array}$ \\
\hline $\begin{array}{l}\text { 101. essere un } \\
\text { agnello fra i lupi } \\
\text { (= biti janje } \\
\text { među } \\
\text { vukovima) }\end{array}$ & $\begin{array}{l}\text { biti kao janje } \\
\text { (ovca) među } \\
\text { vukovima }\end{array}$ & $\begin{array}{l}\text { 'naći se u } \\
\text { nepovoljnu } \\
\text { okružju, biti } \\
\text { okružen } \\
\text { neprijateljima' }\end{array}$ & $\begin{array}{l}\text { sintaktička i } \\
\text { leksička }\end{array}$ \\
\hline $\begin{array}{l}\text { 102. l'angelo del } \\
\text { Paradiso } \\
\text { (= anđeo raja) }\end{array}$ & pravi anđeo & $\begin{array}{l}\text { 'izrazito blaga i } \\
\text { dobronamjerna } \\
\text { osoba' }\end{array}$ & $\begin{array}{l}\text { morfosintaktička i } \\
\text { leksička }\end{array}$ \\
\hline
\end{tabular}




\begin{tabular}{|c|c|c|c|}
\hline $\begin{array}{l}\text { 103. cospargersi il } \\
\text { capo di cenere } \\
\text { (= posuti sebi } \\
\text { glavu } \\
\text { pepelom) }\end{array}$ & $\begin{array}{l}\text { posuti se } \\
\text { pepelom }\end{array}$ & $\begin{array}{l}\text { 'kajati se, } \\
\text { pokajati se' }\end{array}$ & $\begin{array}{l}\text { leksička i } \\
\text { sintaktička }\end{array}$ \\
\hline $\begin{array}{l}\text { 104. essere una } \\
\text { canna al vento } \\
\text { (= biti trska na } \\
\text { vjetru) }\end{array}$ & $\begin{array}{l}\text { tresti se kao } \\
\text { trska }<\text { na } \\
\text { vjetru }>\end{array}$ & $\begin{array}{l}\text { 'biti nestabilan, } \\
\text { lako mijenjati } \\
\text { mišljenje' }\end{array}$ & $\begin{array}{l}\text { leksička i } \\
\text { sintaktička }\end{array}$ \\
\hline $\begin{array}{l}\text { 105. dar a Cesare } \\
\text { quel che è di } \\
\text { Cesare } \\
\text { (= dati Cezaru } \\
\text { ono što je } \\
\text { Cezarovo) }\end{array}$ & $\begin{array}{l}\text { dati caru } \\
\text { carevo, <a Bogu } \\
\text { Božje> }\end{array}$ & $\begin{array}{l}\text { 'priznati } \\
\text { svakomu prava i } \\
\text { zasluge koje mu } \\
\text { pripadaju' }\end{array}$ & $\begin{array}{l}\text { sintaktička i } \\
\text { leksička }\end{array}$ \\
\hline $\begin{array}{l}\text { 106. essere } \\
\text { (sentirsi) come } \\
\text { Davide contro } \\
\text { Golia } \\
\text { (= biti (osjećati } \\
\text { se) kao David } \\
\text { protiv } \\
\text { Golijata) }\end{array}$ & $\begin{array}{l}\text { borba Davida i } \\
\text { Golijata }\end{array}$ & $\begin{array}{l}\text { 'neravnopravna } \\
\text { borba' }\end{array}$ & $\begin{array}{l}\text { leksička i } \\
\text { sintaktička }\end{array}$ \\
\hline $\begin{array}{l}\text { 107. essere (come) } \\
\text { il diavolo e } \\
\text { l'acqua santa } \\
\text { (= biti (kao) } \\
\text { vrag i sveta voda) }\end{array}$ & $\begin{array}{l}\text { bježati kao vrag } \\
\text { od svete vode } \\
\text { (tamjana) }\end{array}$ & $\begin{array}{l}\text { 'ne podnositi } \\
\text { koga što; bježati } \\
\text { od čega' }\end{array}$ & $\begin{array}{l}\text { leksička i } \\
\text { sintaktička }\end{array}$ \\
\hline $\begin{array}{l}\text { 108. avere il } \\
\text { diavolo in corpo } \\
\text { (per capello) }\end{array}$ & u kome je đavao & $\begin{array}{l}\text { 'biti izrazito } \\
\text { nemirna i } \\
\text { nespokojna } \\
\text { osoba' (Rabi se i }\end{array}$ & $\begin{array}{l}\text { leksička i } \\
\text { sintaktička }\end{array}$ \\
\hline
\end{tabular}




\begin{tabular}{|c|c|c|c|}
\hline $\begin{array}{l}\text { (= imati vraga } \\
\text { u tijelu (na } \\
\text { kosi)) }\end{array}$ & & $\begin{array}{l}\text { za nestašnu } \\
\text { djecu.) }\end{array}$ & \\
\hline $\begin{array}{l}\text { 109. mettere la } \\
\text { fiaccola sotto il } \\
\text { moggio (var. } \\
\text { nascondere } \\
\text { sotto il moggio; } \\
\text { nascondersi } \\
\text { sotto il moggio) } \\
\text { (= staviti luč } \\
\text { (buktinju) pod } \\
\text { mjericu (lonac)) }\end{array}$ & $\begin{array}{l}\text { metnuti svijeću } \\
\text { pod lonac }\end{array}$ & $\begin{array}{l}\text { 'raditi beskorisnu } \\
\text { stvar, stvar od } \\
\text { koje nitko nema } \\
\text { koristi; skrivati } \\
\text { istinu' }\end{array}$ & $\begin{array}{l}\text { sintaktička i } \\
\text { leksička }\end{array}$ \\
\hline $\begin{array}{l}\text { 110. avere la } \\
\text { pazienza di } \\
\text { Giobbe } \\
\text { (= imati } \\
\text { Jobovo } \\
\text { strpljenje })\end{array}$ & $\begin{array}{l}\text { biti strpljiv kao } \\
\text { Job }\end{array}$ & $\begin{array}{l}\text { 'biti vrlo strpljiva } \\
\text { osoba' }\end{array}$ & $\begin{array}{l}\text { sintaktička i } \\
\text { leksička }\end{array}$ \\
\hline $\begin{array}{l}\text { 111. parere il } \\
\text { Giorno del } \\
\text { Giudizio } \\
<\text { Universale> } \\
\text { (= činiti se } \\
\text { danom } \\
<\text { Općega> } \\
\text { suda) }\end{array}$ & $\begin{array}{l}\text { Kao da je } \\
\text { Sudnji dan! }\end{array}$ & $\begin{array}{l}\text { 'veliko } \\
\text { nevrijeme; } \\
\text { trenutak velikoga } \\
\text { nemira i } \\
\text { pomutnje' }\end{array}$ & $\begin{array}{l}\text { leksička, } \\
\text { morfološka i } \\
\text { sintaktička }\end{array}$ \\
\hline $\begin{array}{l}\text { 112. essere un } \\
\text { Giuda (var. fare } \\
\text { la parte di } \\
\text { Giuda) } \\
\text { (= biti Juda ) }\end{array}$ & $\begin{array}{l}\text { biti Juda } \\
<\text { Iškariotski }>\end{array}$ & 'biti izdajnik' & $\begin{array}{l}\text { leksička i } \\
\text { sintaktička u } \\
\text { talijanskome; }\end{array}$ \\
\hline
\end{tabular}




\begin{tabular}{|c|c|c|c|}
\hline & & & $\begin{array}{l}\text { fakultativna } \\
\text { leksička sastavnica } \\
\text { u hrvatskome }\end{array}$ \\
\hline $\begin{array}{l}\text { 113. non } \\
\text { tralasciare il più } \\
\text { piccolo iota } \\
\text { (= ne izostaviti } \\
\text { ni najmanju jotu })\end{array}$ & ni (niti) za jotu & $\begin{array}{l}\text { 'nimalo, ni u } \\
\text { najmanjoj mjeri' }\end{array}$ & $\begin{array}{l}\text { leksička i } \\
\text { sintaktička }\end{array}$ \\
\hline $\begin{array}{l}\text { 114. non legare } \\
\text { neanche } \mathbf{i} \\
\text { calzari } \boldsymbol{a} \\
\text { qualcuno } \\
\text { (= čak niti } \\
\text { vezati obuću } \\
\text { komu })\end{array}$ & $\begin{array}{l}\text { ne biti vrijedan } \\
\text { odriješiti } k o m u \\
\text { obuću }\end{array}$ & $\begin{array}{l}\text { 'ne biti na čijoj } \\
\text { razini, ne moći se } \\
\text { usporediti s } \\
\text { nekom drugom } \\
\text { osobom' }\end{array}$ & $\begin{array}{l}\text { leksička i } \\
\text { sintaktička }\end{array}$ \\
\hline $\begin{array}{l}\text { 115. non far sapere } \\
\text { alla mano } \\
\text { destra quello } \\
\text { che fa la sinistra } \\
\text { (= ne dati da } \\
\text { zna desnica ono } \\
\text { što čini ljevica) }\end{array}$ & $\begin{array}{l}\text { (ne) zna ljevica } \\
\text { što (mi) čini } \\
\text { (radi) desnica }\end{array}$ & $\begin{array}{l}\text { 'biti diskretan i } \\
\text { ne hvastati se } \\
\text { čineći dobro } \\
\text { bližnjemu; ne } \\
\text { baviti se tuđim } \\
\text { poslom' }\end{array}$ & $\begin{array}{l}\text { leksička i } \\
\text { sintaktička }\end{array}$ \\
\hline $\begin{array}{l}\text { 116. vecchio come } \\
\text { Matusalemme } \\
\text { (= star kao } \\
\text { Metuzalem) }\end{array}$ & $\begin{array}{l}\text { star kao } \\
\text { Metuzalem } \\
\text { (metuzalemski } \\
\text { star) }\end{array}$ & 'vrlo stara osoba' & $\begin{array}{l}\text { morfološka i } \\
\text { sintaktička }\end{array}$ \\
\hline $\begin{array}{l}\text { 117. salire al terzo } \\
\text { cielo } \\
\text { (= uspeti se na } \\
\text { treće nebo) }\end{array}$ & treće nebo & $\begin{array}{c}\text { 'mjesto na } \\
\text { kojemu prebiva } \\
\text { Bog, raj' }\end{array}$ & $\begin{array}{l}\text { leksička i } \\
\text { sintaktička }\end{array}$ \\
\hline
\end{tabular}




\begin{tabular}{|c|c|c|c|}
\hline $\begin{array}{r}\text { 118. gettare (dare) } \\
\text { le perle ai porci } \\
(=\text { baciti (dati) } \\
\text { bisere svinjama) }\end{array}$ & $\begin{array}{l}\text { baciti / bacati } \\
\text { bisere (biserje) } \\
\text { pred svinje }\end{array}$ & $\begin{array}{c}\text { 'davati što } \\
\text { vrijedno i } \\
\text { dragocjeno komu } \\
\text { tko ne zna što je } \\
\text { to ili tko to ne } \\
\text { zavrjeđuje' }\end{array}$ & $\begin{array}{l}\text { leksička, } \\
\text { morfološka i } \\
\text { sintaktička }\end{array}$ \\
\hline $\begin{array}{l}\text { 119. scagliare la } \\
\text { prima pietra } \\
\text { contro qualcuno } \\
\text { (= baciti prvi } \\
\text { kamen na koga) }\end{array}$ & $\begin{array}{l}\text { baciti se } \\
\text { kamenom na } \\
\operatorname{koga}^{105}\end{array}$ & $\begin{array}{l}\text { 'ošto ukoriti čije } \\
\text { grijehe, a da se ne } \\
\text { uzme u obzir i } \\
\text { vlastita grješnost } \\
\text { ili umiješanost' }\end{array}$ & $\begin{array}{l}\text { leksička i } \\
\text { sintaktička }\end{array}$ \\
\hline $\begin{array}{l}\text { 120. } \\
\text { sudar sangue } \\
(=\text { znojiti se } \\
\text { krvlju })\end{array}$ & krvavi znoj & $\begin{array}{l}\text { 'podnositi velike } \\
\text { muke i žrtve da } \\
\text { bi se došlo do } \\
\text { nekoga cilja' }\end{array}$ & $\begin{array}{l}\text { leksička i } \\
\text { sintaktička }\end{array}$ \\
\hline $\begin{array}{l}\text { 121. essere una } \\
\text { serpente } \\
\text { (= biti zmija) }\end{array}$ & $\begin{array}{l}\text { biti lukav kao } \\
\text { zmija (poput } \\
\text { zmije) }\end{array}$ & $\begin{array}{c}\text { 'vrlo prijetvorna i } \\
\text { zla osoba' }\end{array}$ & $\begin{array}{l}\text { sintaktička i } \\
\text { leksička }\end{array}$ \\
\hline $\begin{array}{l}\text { 122. prendere per } \\
\text { vangelo } \\
\text { (= uzeti kao } \\
\text { evanđelje) }\end{array}$ & Sveto pismo & 'što nepovredivo' & $\begin{array}{l}\text { leksička i } \\
\text { sintaktička }\end{array}$ \\
\hline $\begin{array}{l}\text { 123. tempo } \\
\text { (periodo) di } \\
\text { vacche grasse } \\
\text { (magre) }\end{array}$ & $\begin{array}{l}\text { sedam debelih } \\
\text { (mršavih, } \\
\text { gladnih) krava } \\
\text { (godina) }\end{array}$ & $\begin{array}{c}\text { 'razdoblje } \\
\text { blagostanja, } \\
\text { odnosno } \\
\text { oskudice' }\end{array}$ & $\begin{array}{l}\text { leksička i } \\
\text { sintaktička }\end{array}$ \\
\hline
\end{tabular}

${ }^{105} \mathrm{U}$ hrvatskome se također gdjekad rabi oblik baciti prvi kamen. 


\begin{tabular}{|c|c|c|c|}
\hline $\begin{array}{l}\text { 124. } \text { gridar } \\
\text { vendetta }<\text { al } \\
\text { cospetto di Dio> } \\
\text { (= vapiti za } \\
\text { osvetom <pred } \\
\text { licem } \\
\text { Božjim }>\text { ) }\end{array}$ & $\begin{array}{l}\text { u nebo vapijući } \\
\text { grijeh }\end{array}$ & $\begin{array}{c}\text { 'biti nešto } \\
\text { gnjusno, što } \\
\text { zaslužuje Božju } \\
\text { kaznu' (Rabi se } \\
\text { za što veoma } \\
\text { ružno ili loše } \\
\text { napravljeno, čak i } \\
\text { šaljivo. Aludira } \\
\text { na biblijski opis } \\
\text { kako Kajin ubija } \\
\text { brata Abela i time } \\
\text { izaziva božji } \\
\text { gnjev i osvetu. } \\
\text { Premda izraz } \\
\text { postoji i u } \\
\text { biblijskom tekstu } \\
\text { na hrvatskome, } \\
\text { ne postoji sličan } \\
\text { frazem } \\
\text { biblijskoga } \\
\text { podrijetla.) }\end{array}$ & $\begin{array}{l}\text { morfološka, } \\
\text { sintaktička i } \\
\text { leksička }\end{array}$ \\
\hline $\begin{array}{l}\text { 125. dividere il } \\
\text { grano dalla } \\
\text { zizzania } \\
\text { (= odvojiti žito } \\
\text { od kukolja) }\end{array}$ & $\begin{array}{l}\text { razdvojiti } \\
\text { (odvojiti, } \\
\text { razdijeliti) žito } \\
\text { od kukolja (var. } \\
\text { odijeliti } \\
\text { (odvojiti) kukolj } \\
\text { od pšenice) }\end{array}$ & $\begin{array}{l}\text { 'odnosi se na } \\
\text { pravednika koji } \\
\text { pušta da raste } \\
\text { kukolj uz žito da } \\
\text { ne bi oštetio žito } \\
\text { čupajući kukolj' }\end{array}$ & $\begin{array}{l}\text { leksička i } \\
\text { sintaktička }\end{array}$ \\
\hline
\end{tabular}

Razlike u svim trima područjima djelomične ekvivalentnosti, a osobito u području c (frazemi biblijskoga podrijetla imaju isto cjelokupno značenje, ali postoje razlike i u morfologiji i sintaksi ili u leksičkim sastavnicama) iznimno je teško ukratko opisati i svaki bi primjer zahtijevao posebnu raščlambu i međujezičnu usporedbu. Stoga se ovo može držati samo 
okvirnim napomenama. Neki su se od tih ekvivalentnih, nekongruentnih frazema mogli uključiti i u čisto semantičku ekvivalentnost. Stoga ne isključujemo i drukčije stavove drugih istraživača. Zbog njihovih odgovarajućih semantičkih i pragmatičkih obilježja u obama jezicima uključili smo ih u skupinu djelomičnih ekvivalenata.

\subsection{3. Čisto semantička ekvivalentnost}

O čisto semantičkoj ekvivalentnosti govorimo kada ne postoje podudarnosti ni u broju sastavnica, ni u slici na kojoj se temelji značenje. Posrijedi je čisto funkcionalna ekvivalentnost i značenje je samo približno isto (usp. Zeman 2005, 309). Kadšto nije lako odrediti granicu između čisto semantičke i nulte ekvivalentnosti.

\begin{tabular}{|l|l|l|l|}
\hline FRAZEM/TALIJANSKI & ZNAČENJE & FRAZEM/HRVATSKI & ZNAČENJE \\
\hline 126. chiudere con & 'dobro i & knjiga sa sedam & 'nešto je \\
& brižno & pečata & posve \\
& zatvoriti & & zatvoreno, \\
& jamčeći & & neshvatljivo, \\
& potpunu & & neprozirno i \\
& sigurnost & & zaštićeno' \\
& sadržaja' & & \\
\hline
\end{tabular}

\subsubsection{Nulta ekvivalentnost}

Nulta ekvivalentnost predstavlja u biti posvemašnje nepostojanje bilo kakvih sličnosti između dvaju frazema.

Usprkos svemu, valja računati s nepostojanjem frazeoloških ekvivalenata „na temelju različne segmentacije jezične stvarnosti. U brojnim slučajevima nacionalna specifičnost u velikoj mjeri onemogućuje strukturno-semantičku ekvivalentnost“" (Hessky 1987, 51 prema Chrissou 2000, $155)$.

Tomu tipu ekvivalentnosti uglavnom pripadaju frazemi $\mathrm{s}$ frazeološki vezanim sastavnicama, nacionalni frazemi te neki idiomi. Oni predstavljaju problem osobito 
prevoditeljima koji moraju onda ,,izraziti denotativno značenje opisom ili tumačenjem u drugome jeziku; pragmatično djelovanje pri tome najčešće se gubi. Takvi proizvodi (tumačenja) mogu prema Földesu igrati ulogu pomoćnoga ekvivalenta“ (Zeman 2006, 310). Unatoč zemljopisnoj blizini i izraženom utjecaju latinske liturgije i latinskoga prijevoda Biblije talijanski i hrvatski jezik često su živjeli pod drukčijim geopolitičkim utjecajima. Nerijetko su i kulturni utjecali bili posve drukčiji. Stoga ne čudi postojanje frazema koji nemaju jednakovrijednice u drugome jeziku. Za neke od frazema moglo bi se nagađati imaju li / jesu li imali jednakovrijednice u nekim istarskim i dalmatinskim narječjima bilo da su posrijedi kalkovi ili istodobno stvaranje frazema u dvjema jezičnim zajednicama zahvaljujući jasnoj slici koju taj izraz iz Biblije pruža.

U ovoj raščlambi posebice smo se ograničili na ekvivalente među frazemima biblijskoga podrijetla u standardnome talijanskom i hrvatskom jeziku.

Talijanski frazemi biblijskoga podrijetla koji nemaju hrvatske jednakovrijednice:

\begin{tabular}{|c|c|c|}
\hline $\begin{array}{c}\text { FRAZEM/ } \\
\text { TALIJANSKI }\end{array}$ & $\begin{array}{c}\text { DOSLOVAN } \\
\text { PRIJEVOD }\end{array}$ & ZNAČENJE \\
\hline 127. il vecchio Adamo & $=$ stari Adam & $\begin{array}{l}\text { 'ljudi, ljudska narav, čovjek } \\
\text { koji nije očišćen, oslobođen } \\
\text { od krivnje' }\end{array}$ \\
\hline $\begin{array}{l}\text { 128. essere parente per } \\
\text { parte di Adamo }\end{array}$ & $\begin{array}{c}=\text { biti rođak po Adamovoj } \\
\text { strani }\end{array}$ & $\begin{array}{l}\text { 'daleki rođak, bez ikakvoga } \\
\text { bliskog srodstva; rođak } \\
\text { samo po Adamu, jedinomu } \\
\text { zajedničkom pretku' }\end{array}$ \\
\hline $\begin{array}{l}\text { 129. venire dalla costola } \\
\text { d'Adamo (var. } \\
\text { discendere dalla } \\
\text { costola d'Adamo) }\end{array}$ & $\begin{array}{c}=\text { doći / dolaziti iz Adamova } \\
\text { rebra (var. potjecati od } \\
\text { Adamova rebra) }\end{array}$ & $\begin{array}{l}\text { 'pripadati ljudskoj vrsti kao } \\
\text { potomak prvoga čovjeka; } \\
\text { ironično: imati iskonsku i } \\
\text { neiskvarenu plemenitost' }\end{array}$ \\
\hline 130. dall'alfa all'omega & $=$ od alfe do omege & 'od početka do kraja' \\
\hline $\begin{array}{l}\text { 131. esser vecchio } \\
\text { quanto l'alleluia }\end{array}$ & = biti star kao aleluja & 'biti iznimno stara osoba' \\
\hline
\end{tabular}




\begin{tabular}{|c|c|c|}
\hline $\begin{array}{l}\text { 132. sacrificare qualcuno } \\
\text { qualcosa sull'altare di } \\
\text { qualcuno qualcosa }\end{array}$ & $\begin{array}{c}=\text { žrtvovati } k \text { oga što na čijem } \\
\text { oltaru }\end{array}$ & $\begin{array}{c}\text { 'žrtvovati koga što u korist } \\
\text { drugoga' }\end{array}$ \\
\hline $\begin{array}{l}\text { 133. l'angelo delle } \\
\text { tenebre }\end{array}$ & $=$ andeo tame & 'đavao, vrag' \\
\hline $\begin{array}{l}\text { 134. bello/bella come un } \\
\text { angelo }\end{array}$ & $=$ lijep/a/o kao anđeo & 'izuzetno lijepa osoba' \\
\hline $\begin{array}{l}\text { 135. soffrire come } \\
\text { un'anima dannata }\end{array}$ & $=$ patiti kao prokleta duša & 'podnositi neizmjerne patnje' \\
\hline 136. arca di scienza & $=$ korablja znanja & 'izuzetno obrazovana osoba' \\
\hline $\begin{array}{l}\text { 137. essere un vecchio } \\
\text { bacucco }\end{array}$ & $=$ biti stari Habakuk & 'biti vrlo star' \\
\hline $\begin{array}{l}\text { 138. prendere san Pietro } \\
\text { per la barba }\end{array}$ & $\begin{array}{c}=\text { uzeti svetoga Petra za } \\
\text { bradu }\end{array}$ & $\begin{array}{c}\text { 'bezočno lagati' (Sveti je } \\
\text { Petar naime tri puta } \\
\text { zanijekao Isusa lažući da ga } \\
\text { ne poznaje.) }\end{array}$ \\
\hline 139. andare in Cafarnao & = ići u Kafarnaum & $\begin{array}{c}\text { 'izgubiti se, nestati u } \\
\text { mnoštvu' }\end{array}$ \\
\hline 140. essere una Cafarnao & = biti Kafarnaum & $\begin{array}{c}\text { 'biti vrlo napučeno mjesto } \\
\text { prepuno ljudi' }\end{array}$ \\
\hline $\begin{array}{l}\text { 141. mandare in } \\
\text { Cafarnao }\end{array}$ & $=$ poslati u Kafarnaum & 'proždrljivo jesti, žderati' \\
\hline $\begin{array}{l}\text { 142. essere ramingo } \\
\text { come Caino }\end{array}$ & $\begin{array}{c}=\text { biti besciljan, lutalica kao } \\
\text { Kajin }\end{array}$ & $\begin{array}{l}\text { 'biti osoba koju svi tjeraju od } \\
\text { sebe zbog njezinih krivica' }\end{array}$ \\
\hline 143. offerta di Caino & $\begin{array}{c}=\text { Kajinov prinos, Kajinova } \\
\text { žrtva }\end{array}$ & $\begin{array}{l}\text { 'neiskren prinos, neiskrena } \\
\text { ponuda, učinjena nerado' }\end{array}$ \\
\hline 144. colomba della pace & $=$ golubica mira & $\begin{array}{c}\text { 'osoba koja može pomiriti } \\
\text { zavađene, često u } \\
\text { ironičnome smislu' }\end{array}$ \\
\hline $\begin{array}{l}\text { 145. Molti sono i } \\
\text { chiamati. }\end{array}$ & $=$ Mnogo je pozvanih. & $\begin{array}{l}\text { 'rabi se ironično za nekoga } \\
\text { tko ne uspije u nekome } \\
\text { pothvatu od kojega se }\end{array}$ \\
\hline
\end{tabular}




\begin{tabular}{|c|c|c|}
\hline & & $\begin{array}{c}\text { očekivao uspjeh ili koga su } \\
\text { drugi nadmašili' }\end{array}$ \\
\hline $\begin{array}{l}\text { 146. consumare il bene } \\
\text { di sette chiese }\end{array}$ & $\begin{array}{c}=\text { potrošiti imanje sedam } \\
\text { crkava }\end{array}$ & $\begin{array}{c}\text { 'sve potrošiti, spiskati } \\
\text { imetak' }\end{array}$ \\
\hline $\begin{array}{l}\text { 147. aprire gli occhi ai } \\
\text { ciechi }\end{array}$ & $=$ otvoriti oči slijepcima & $\begin{array}{c}\text { 'objasniti, poučiti, objaviti } \\
\text { neku istinu' }\end{array}$ \\
\hline 148. andare dal Creatore & $=$ otići $\mathrm{k}$ Stvoritelju & 'umrijeti' \\
\hline $\begin{array}{l}\text { 149. mandare dal } \\
\text { Creatore qualcuno }\end{array}$ & $=($ po)slati koga $\mathrm{k}$ Stvoritelju & 'ubiti' \\
\hline $\begin{array}{l}\text { 150. con tutti i crismi }<\mathrm{e} \\
\text { sacrismi }>\end{array}$ & = sa svim pomastima & $\begin{array}{c}\text { 'besprijekorno, pridržavajući } \\
\text { se svih pravila' }\end{array}$ \\
\hline $\begin{array}{l}\text { 151. essere un povero } \\
\text { Cristo }\end{array}$ & $=$ biti siromašni Krist & $\begin{array}{c}\text { 'biti jadnik, osoba koja } \\
\text { izaziva sažaljenje' }\end{array}$ \\
\hline $\begin{array}{l}\text { 152. dare a intendere che } \\
\text { Cristo è morto di } \\
\text { sonno (var. dare a } \\
\text { intendere che Cristo è } \\
\text { morto di freddo) }\end{array}$ & $\begin{array}{c}\text { = dati razumjeti da je Krist } \\
\text { umro od pospanosti (var. } \\
\text { dati razumjeti da je Krist } \\
\text { umro od hladnoće) }\end{array}$ & $\begin{array}{l}\text { 'pričati neistine, navoditi } \\
\text { često i apsurdnosti kako bi } \\
\text { se ostvario neki cilj; također } \\
\text { i predstaviti jednu stvar } \\
\text { drugom' }\end{array}$ \\
\hline $\begin{array}{l}\text { 153. dare (gettare) la } \\
\text { croce addosso } a \\
\text { qualcuno }\end{array}$ & $=$ nabaciti križ na koga & 'teško okriviti koga' \\
\hline $\begin{array}{l}\text { 154. dire quattro parole } \\
\text { in croce }\end{array}$ & $=$ reći četiri riječi na križu & 'govoriti malo ili loše' \\
\hline $\begin{array}{l}\text { 155. essere (stare) in } \\
\text { croce }\end{array}$ & $=$ biti na križu & 'biti iznimno zabrinut' \\
\hline $\begin{array}{l}\text { 156. essere un cireneo } \\
\text { (var. fare il cireneo) }\end{array}$ & = biti Cirenac & $\begin{array}{c}\text { 'prihvatiti obveze koje bi tko } \\
\text { drugi trebao riješiti ili } \\
\text { podnositi patnje za koga } \\
\text { drugog; podijeliti muke s } \\
\text { kim kako bi mu se pomoglo' }\end{array}$ \\
\hline
\end{tabular}




\begin{tabular}{|c|c|c|}
\hline $\begin{array}{l}\text { 157. essere sulla via di } \\
\text { Damasco }\end{array}$ & $=$ biti na putu u Damask & $\begin{array}{c}\text { 'biti blizu obraćenju i } \\
\text { pokajanju' (Frazem se } \\
\text { odnosi na svetoga Pavla.) }\end{array}$ \\
\hline 158. essere il beniamino & $=$ biti Benjamin & 'biti izabran' \\
\hline $\begin{array}{l}\text { 159. mescolare ebrei e } \\
\text { samaritani }\end{array}$ & $\begin{array}{c}=\text { miješati Hebreje i } \\
\text { Samarijce }\end{array}$ & $\begin{array}{c}\text { 'izmiješati stvari ili osobe } \\
\text { koje su u protimbi' }\end{array}$ \\
\hline 160. essere un ecce homo & $=$ biti ecce homo & $\begin{array}{l}\text { 'biti u lošemu stanju, } \\
\text { izranjen i premlaćen' }\end{array}$ \\
\hline 161. andare in Emmaus & $=$ ići u Emaus & $\begin{array}{c}\text { 'biti vrlo rastresen; ne } \\
\text { prepoznati osobu koju svi } \\
\text { poznaju' (Frazem potječe iz } \\
\text { evanđeoskoga teksta koji } \\
\text { opisuje dvojicu apostola koji } \\
\text { idu u Emaus skupa s Isusom } \\
\text { i ne uspijevaju ga } \\
\text { prepoznati.) }\end{array}$ \\
\hline 162. Chiamate Erode! & $=$ Pozovite Heroda! & $\begin{array}{l}\text { 'ovaj usklik rabi se šaljivo } \\
\text { pred nestašnim djetetom i } \\
\text { podsjeća na Herodov progon } \\
\text { nevine dječice' }\end{array}$ \\
\hline $\begin{array}{l}\text { 163. essere come i soldati } \\
\text { del re Erode }\end{array}$ & $\begin{array}{c}\text { = biti kao vojnici kralja } \\
\text { Heroda }\end{array}$ & $\begin{array}{c}\text { 'biti loše organizirani i u } \\
\text { neredu kako se često u } \\
\text { ikonografiji prikazuju } \\
\text { vojnici židovskoga kralja } \\
\text { Heroda premda to } \\
\text { povjesničari nigdje ne } \\
\text { spominju' }\end{array}$ \\
\hline $\begin{array}{l}\text { 164. essere (trovarsi) } \\
\text { nella fossa dei leoni }\end{array}$ & $\begin{array}{c}=\text { biti (naći se) u lavljoj } \\
\text { jazbini (jami) }\end{array}$ & $\begin{array}{l}\text { 'biti u velikoj pogibelji, } \\
\text { suočiti se s mnoštvom } \\
\text { problema' }\end{array}$ \\
\hline $\begin{array}{l}\text { 165. essere come il gallo } \\
\text { che cantò a san Pietro }\end{array}$ & $\begin{array}{l}\text { = biti kao pijetao koji } \\
\text { zapjeva svetomu Petru }\end{array}$ & $\begin{array}{c}\text { 'kaže se o mesu staroga i } \\
\text { tvrdoga pijetla koje nije } \\
\text { ugodno za jelo' }\end{array}$ \\
\hline
\end{tabular}




\begin{tabular}{|c|c|c|}
\hline 166. fare una Geremiade & $=$ praviti jeremijadu & $\begin{array}{l}\text { 'tužiti se; kukati' (Izraz se } \\
\text { odnosi na proroka Jeremiju } \\
\text { koji je sastavio tužaljke u } \\
\text { kojima se oplakuje uništenje } \\
\text { i opustošenje Jeruzalema.) }\end{array}$ \\
\hline $\begin{array}{l}\text { 167. rimandare al } \\
\text { Giorno del Giudizio }\end{array}$ & $=$ odgoditi do Sudnjega dana & $\begin{array}{l}\text { 'odgoditi na neodređeno } \\
\text { vrijeme; najčešće se misli na } \\
\text { nešto što se nikada ne će } \\
\text { dogoditi' }\end{array}$ \\
\hline $\begin{array}{l}\text { 168. fare il casto } \\
\text { Giuseppe }\end{array}$ & $=$ biti čisti Josip & $\begin{array}{c}\text { 'držati se kao častan čovjek' } \\
\text { (Frazem se odnosi na Josipa, } \\
\text { sina Jakovljeva.) }\end{array}$ \\
\hline $\begin{array}{l}\text { 169. venire dal grembo } \\
\text { di Dio (var. essere nel } \\
\text { grembo di Dio) }\end{array}$ & $\begin{array}{c}\text { = doći iz Božjega krila } \\
\text { (var. biti u Božjemu krilu) }\end{array}$ & $\begin{array}{c}\text { 'imati nepoznato podrijetlo } \\
\text { ili uzrok' }\end{array}$ \\
\hline $\begin{array}{l}\text { 170. gridare il } \\
\text { cruciffigge }\end{array}$ & $=$ vikati raspni & $\begin{array}{c}\text { 'nasrnuti na } k o g a, \text { učiniti ga } \\
\text { žrtvenim jarcem' }\end{array}$ \\
\hline $\begin{array}{l}\text { 171. (essere) un'ira di } \\
\text { Dio (var. un'ira } \\
\text { d'Iddio) }\end{array}$ & $\begin{array}{c}=\text { biti srdžba Božja (var. } \\
\text { srdžba Božja) }\end{array}$ & $\begin{array}{l}\text { 'velika količina nečega ili } \\
\text { stvar koja potječe od } \\
\text { mnoštva osoba. Drugo } \\
\text { značenje: teška i pogubna } \\
\text { situacija nastala kao } \\
\text { posljedica uglavnom } \\
\text { meteoroloških pojava kao } \\
\text { što su snijeg, mraz itd.' }\end{array}$ \\
\hline $\begin{array}{l}\text { 172. sembrare Lazzaro } \\
\text { risucitato }\end{array}$ & $=$ činiti se uskrslim Lazarom & $\begin{array}{l}\text { 'biti iznimno mršav, izgledati } \\
\text { kao mrtvac koji je čudesno } \\
\text { uskrišen' }\end{array}$ \\
\hline 173. legarsela al dito & $=$ privezati sebi za prst & $\begin{array}{l}\text { 'pretrpljena nepravda za koju } \\
\text { se } t k o \text { želi osvetiti.' (Frazem }\end{array}$ \\
\hline
\end{tabular}




\begin{tabular}{|c|c|c|}
\hline & & $\begin{array}{c}\text { potječe iz knjige Brojeva } \\
6,8 .)\end{array}$ \\
\hline $\begin{array}{l}\text { 174. la maddalena } \\
\text { <pentita }>\end{array}$ & $=$ Magdalena $<$ pokajnica $>$ & $\begin{array}{l}\text { 'žena koja se pokazuje } \\
\text { poniznom i pokajnicom s } \\
\text { primjesom licemjerja, žena } \\
\text { koja hini poniznost i } \\
\text { dobrotu' }\end{array}$ \\
\hline 175. mandato da Dio & $=$ poslan od Boga & $\begin{array}{c}\text { 'providonosan, kao pomoć s } \\
\text { neba' (Rabi se za ljude ili } \\
\text { stvari, također i ironično.) }\end{array}$ \\
\hline 176. toccare con mano & $=$ dodirnuti rukom & 'osobno se uvjeriti u što' \\
\hline $\begin{array}{l}\text { 177. fare da Marta e da } \\
\text { Maddalena }\end{array}$ & $\begin{array}{c}=\text { činiti kao Marta i } \\
\text { Magdalena }\end{array}$ & 'činiti oprječne stvari' \\
\hline 178. aspettare il Messia & $=$ čekati Mesiju & $\begin{array}{c}\text { 'čekati dugo i s povjerenjem, } \\
\text { najčešće uzalud' }\end{array}$ \\
\hline $\begin{array}{l}\text { 179. restare come la } \\
\text { moglie di Lot }\end{array}$ & $=$ ostati kao Lotova supruga & $\begin{array}{l}\text { 'biti zgranut, ukočen od } \\
\text { čuđenja i iznenađenja' }\end{array}$ \\
\hline 180. farne quanto Nemo & $=$ činiti kao Nemo & $\begin{array}{c}\text { 'biti vrlo zaposlen i djelatan' } \\
\text { (Ime Nemo nastalo je u } \\
\text { mašti naroda koji je uzeo } \\
\text { latinsku zamjenicu nemo } \\
\text { 'nitko' iz Svetoga pisma i } \\
\text { doživljavao je kao vlastito } \\
\text { ime.) }\end{array}$ \\
\hline $\begin{array}{l}\text { 181. essere nero come } \\
\text { l'anima di Giuda }\end{array}$ & = biti crn kao Judina duša & $\begin{array}{c}\text { 'imati nečistu savjest; imati } \\
\text { velike krivnje' }\end{array}$ \\
\hline $\begin{array}{l}\text { 182. (essere) (vecchio) } \\
\text { come l'arca di Noè }\end{array}$ & $\begin{array}{c}=(\text { biti }) \text { (star) kao Noina } \\
\text { korablja }\end{array}$ & 'biti vrlo star' \\
\hline
\end{tabular}




\begin{tabular}{|c|c|c|}
\hline $\begin{array}{l}\text { 183. avere gli anni di } \\
\text { Noè (var. vecchio } \\
\text { come Noè) }\end{array}$ & $\begin{array}{c}\text { = imati Noine godine (var. } \\
\text { biti star kao Noa) }\end{array}$ & $\begin{array}{l}\text { 'biti vrlo star, biti u } \\
\text { poodmakloj dobi' }\end{array}$ \\
\hline 184. ai tempi di Noè & $=\mathrm{u}$ Noino vrijeme & $\begin{array}{l}\text { 'u davnini, vrlo davno' (Kao } \\
\text { primjerice u vrijeme kada je } \\
\text { Noa živio. Noa je bio } \\
\text { patrijarh kojemu je Bog } \\
\text { naložio da izgradi korablju } \\
\text { kako bi spasio živa bića od } \\
\text { općega potopa.) }\end{array}$ \\
\hline $\begin{array}{l}\text { 185. passare dall'osanna } \\
\text { al crucifigge }\end{array}$ & $=$ prijeći s hosana na raspni & $\begin{array}{l}\text { 'prijeći s uspjeha na propast i } \\
\text { sramotu' }\end{array}$ \\
\hline $\begin{array}{l}\text { 186. portare il ramo } \\
\text { d'olivo (var. porgere il } \\
\text { ramo d'olivo; offrire } \\
\text { il ramo d'olivo) }\end{array}$ & $\begin{array}{c}=\text { nositi maslinovu grančicu } \\
\text { (var. pružiti maslinovu } \\
\text { grančicu; ponuditi } \\
\text { maslinovu grančicu) }\end{array}$ & $\begin{array}{l}\text { 'nagovijestiti mir ili nositi } \\
\text { prijedlog mira ili pokazivati } \\
\text { volju za mirom. Također i } \\
\text { potruditi se oko okončanja } \\
\text { neke svađe itd.' }\end{array}$ \\
\hline $\begin{array}{l}\text { 187. essere l'operaio } \\
\text { dell'ultima ora }\end{array}$ & $\begin{array}{c}=\text { biti radnikom posljednjega } \\
\text { sata }\end{array}$ & $\begin{array}{c}\text { 'doći kao posljednji, a } \\
\text { zahtijevati ista prava, } \\
\text { naknade i priznanja kao i oni } \\
\text { koji su došli prvi' }\end{array}$ \\
\hline $\begin{array}{l}\text { 188. pagare nella valle di } \\
\text { Giosafat }\end{array}$ & $=$ platiti u dolini Jozafat & $\begin{array}{c}\text { 'odgoditi plaćanje neke } \\
\text { obveze ili duga do prigode } \\
\text { za koju se zna da se ne će } \\
\text { nikada dogoditi; u biti, } \\
\text { nikada ne platiti' (Dolina } \\
\text { Jozafat je prema Bibliji } \\
\text { dolina u kojoj će Bog } \\
\text { prikupiti sve narode na sud.) }\end{array}$ \\
\hline
\end{tabular}




\begin{tabular}{|c|c|c|}
\hline $\begin{array}{l}\text { 189. guardare la paglia e } \\
\text { non vedere la trave }\end{array}$ & $\begin{array}{c}=\text { gledati trun, a ne vidjeti } \\
\text { brvno }\end{array}$ & $\begin{array}{l}\text { 'koriti tuđe grijehe, a ne } \\
\text { vidjeti vlastite. U širemu } \\
\text { smislu, paziti na sitnice, a ne } \\
\text { vidjeti ozbiljnije nedostatke' }\end{array}$ \\
\hline 190. povero in canna & $=$ siromašan na trstici & $\begin{array}{c}\text { 'iznimno siromašna osoba, } \\
\text { bijednik' }\end{array}$ \\
\hline 191. andare a Patrasso & $=$ ići u Patrasso $^{106}$ & 'loše završiti, propasti' \\
\hline $\begin{array}{l}\text { 192. fare <come }>\text { san } \\
\text { Pietro }\end{array}$ & $\begin{array}{c}=\text { biti sveti Petar; učiniti kao } \\
\text { sveti Petar }\end{array}$ & 'zanijekati neku osobu' \\
\hline $\begin{array}{l}\text { 193. brutto come il } \\
\text { peccato }\end{array}$ & $=$ ružan kao grijeh & 'krajnje ružan' \\
\hline 194. povero di spirito & $=$ siromašan duhom & $\begin{array}{l}\text { 'osoba prosječne } \\
\text { inteligencije koja nije kadra } \\
\text { promatrati život kritično ili s } \\
\text { humorom' }\end{array}$ \\
\hline $\begin{array}{l}\text { 195. essere cattivo } \\
\text { profeta }\end{array}$ & $=$ biti loš prorok & $\begin{array}{l}\text { 'izreći jednostavnu prognozu } \\
\text { koju može bilo tko izreći. } \\
\text { Često se rabi ironično za } \\
\text { osobe koje se drže mudrima } \\
\text { i pronicljivima.' }\end{array}$ \\
\hline 196. fare repulisti & $=$ učiniti repulisti & $\begin{array}{c}\text { 'odnijeti sve, potrošiti sve, } \\
\text { pojesti sve' }\end{array}$ \\
\hline $\begin{array}{l}\text { 197. restare (lasciare) di } \\
\text { sale (var. essere } \\
\text { (sembrare) una statua } \\
\text { di sale) }\end{array}$ & $\begin{array}{l}\text { = pretvoriti se u sol (var. } \\
\text { činiti se kipom od soli; ostati } \\
\text { od soli) }\end{array}$ & $\begin{array}{c}\text { 'biti zgranut, zaprepašten' (U } \\
\text { knjizi Stvaranja (XIX, 24- } \\
\text { 26) priča se o Lotovoj ženi } \\
\text { koja se, pošto se okrenula } \\
\text { vidjeti uništenje Sodome i } \\
\text { Gomore, pretvorila u stup } \\
\text { soli.) }\end{array}$ \\
\hline
\end{tabular}

${ }^{106}$ Astionim Patrasso ne odnosi se na drevni grčki grad Patras, nego je nastao krivim razumijevanjem latinske rečenice iz Biblije ire ad patres koja znači 'ići k pretcima' tj. umrijeti. 


\begin{tabular}{|c|c|c|}
\hline 198. segnato da Dio & $=$ obilježen od Boga & $\begin{array}{c}\text { 'netko tko ima neku fizičku } \\
\text { manu' }\end{array}$ \\
\hline $\begin{array}{l}\text { 199. avere la scienza } \\
\text { infusa }\end{array}$ & $=$ imati uliveno znanje & $\begin{array}{l}\text { 'sve znati, uglavnom } \\
\text { ironično' }\end{array}$ \\
\hline 200. il casto sposo & $=$ čedni zaručnik & $\begin{array}{l}\text { 'prema biblijskome izvješću } \\
\text { sveti Josip, zaručnik Marijin, } \\
\text { bio je Isusov skrbnik, a ne } \\
\text { otac' }\end{array}$ \\
\hline 201. stella dei Magi & = zvijezda mudraca & $\begin{array}{c}\text { 'komet koji je prema } \\
\text { kršćanskoj tradiciji vodio } \\
\text { kraljeve mudrace do štalice } \\
\text { u kojoj je rođen Isus Krist' }\end{array}$ \\
\hline $\begin{array}{l}\text { 202. fare la casta } \\
\text { Susanna }\end{array}$ & $=$ biti čedna Suzana & $\begin{array}{c}\text { 'biti kreposna žena' } \\
\text { (Kreposna Suzana u Knjizi } \\
\text { Danijelovoj (XIII) } \\
\text { nepravedno je optužena } \\
\text { poradi preljuba i spasio ju je } \\
\text { prorok Danijel.) }\end{array}$ \\
\hline 203. Beati gli ultimi! & = Blago posljednjima! & $\begin{array}{c}\text { 'šaljivi usklik kako bi se } \\
\text { utješilo one koji su } \\
\text { posljednji u nečemu' }\end{array}$ \\
\hline 204. uomo di poca fede & $=$ malovjeran čovjek & $\begin{array}{c}\text { 'skeptična osoba ili malo } \\
\text { uvjerena u što' }\end{array}$ \\
\hline $\begin{array}{l}\text { 205. vendere qualcosa } \\
\text { per un piatto di } \\
\text { lenticchie }\end{array}$ & $=$ prodati što za tanjur leće & $\begin{array}{c}\text { 'prodati što po cijeni nižoj od } \\
\text { stvarne' (U Knjizi Postanka } \\
(\mathrm{XXV}, 29-34))\end{array}$ \\
\hline $\begin{array}{l}\text { 206. fare la visita di } \\
\text { santa Elisabetta }\end{array}$ & $\begin{array}{c}=\text { ići u posjet kao sveta } \\
\text { Elizabeta }\end{array}$ & $\begin{array}{l}\text { 'ići u dug posjet' (Kako je to } \\
\text { prema svetopisamskome } \\
\text { izvješću činila Gospa koja je }\end{array}$ \\
\hline
\end{tabular}




\begin{tabular}{|c|c|c|}
\hline & & $\begin{array}{l}\text { išla u tromjesečni posjet } \\
\text { svetoj Elizabeti. Rabi se } \\
\text { ironično i šaljivo.) }\end{array}$ \\
\hline $\begin{array}{l}\text { 207. uccidere il vitello } \\
\text { grasso }\end{array}$ & $=$ zaklati ugojeno tele & $\begin{array}{l}\text { 'raskošno proslavljati neki } \\
\text { događaj' (Misli se na } \\
\text { najbolje tele koje se kolje za } \\
\text { proslavu povratka sina } \\
\text { razmetnoga (Luka 15, 23).) }\end{array}$ \\
\hline $\begin{array}{l}\text { 208. voce (il richiamo) } \\
\text { del sangue }\end{array}$ & $=$ glas $(\mathrm{zov}) \mathrm{krvi}$ & $\begin{array}{c}\text { 'instinkt po kojemu se } \\
\text { prepoznaju i vole osobe u } \\
\text { krvnome srodstvu (Postanak } \\
\text { 4,10)' }\end{array}$ \\
\hline $\begin{array}{l}\text { 209. seminare (mettere) } \\
\text { zizzania }\end{array}$ & $=($ po)sijati (staviti) kukolj & 'izazvati podjele i svađe' \\
\hline
\end{tabular}

Hrvatski frazemi biblijskoga podrijetla koji nemaju jednakovrijednice u talijanskome:

\begin{tabular}{|c|c|}
\hline FRAZEM / HRVATSKI & ZNAČENJE \\
\hline $\begin{array}{l}\text { 1. biti primljen (otići) u krilo } \\
\text { Abrahamovo }\end{array}$ & 'umrijeti' \\
\hline 2. Abrahamove godine & 'duboka starost' \\
\hline 3. od Adama do Eve & $\begin{array}{c}\text { 'u cijelosti, potpuno; nadugo i } \\
\text { naširoko' }\end{array}$ \\
\hline 4. I amen (!) & 'I gotovo $(!) '$ \\
\hline 5. <To je> kao amen. & 'sigurna stvar' \\
\hline 6. sigurno kao amen & 'posvema sigurno' \\
\hline 7. pali anđeo & 'otpadnik' \\
\hline $\begin{array}{l}\text { 8. dok je Bog <još> po zemlji } \\
\text { hodao }\end{array}$ & $\begin{array}{c}\text { 'vrijeme izobilja, vrijeme vladavine } \\
\text { prava' }\end{array}$ \\
\hline
\end{tabular}




\begin{tabular}{|c|c|}
\hline 9. osobna (naša) Biblija & 'najvažnija stvar, zakon' \\
\hline 10. otići Bogu na istinu & 'umrijeti' \\
\hline $\begin{array}{l}\text { 11. devu prodjenuti kroz ušice } \\
\text { igle }\end{array}$ & 'učiniti nešto nemoguće' \\
\hline 12. dolina suza (plača) & $\begin{array}{c}\text { 'zemlja kao mjesto poharano } \\
\text { istočnim grijehom gdje pali čovjek } \\
\text { okajava svoju krivicu' }\end{array}$ \\
\hline 13. vječna Eva & 'žena' \\
\hline 14. Evin sin & 'čovjek, smrtnik' \\
\hline 15. Evina kći & 'Žena' \\
\hline 16. Evino koljeno & 'žena uopće' \\
\hline 17. ići apostolski & 'ići pješice' \\
\hline 18. mučiti se kao Isus na križu & 'podnositi velika trpljenja' \\
\hline 19. babilonski jezik & 'nerazumljiv jezik' \\
\hline $\begin{array}{l}\text { 20. pala je komu koprena } \\
\text { (mrena, veo) s očiju }\end{array}$ & $\begin{array}{c}\text { 'progledao je } t k o, \text { postao je } t k o \\
\text { svjestan kako stvari stoje' }\end{array}$ \\
\hline 21. čitati (očitati) komu levite & 'koriti, izgrditi koga' \\
\hline $\begin{array}{l}\text { 22. vratiti / vraćati (staviti / } \\
\text { stavljati) mač (sablju) u } \\
\text { korice }\end{array}$ & 'okončati sukob, spor, prepirku' \\
\hline 23. ići kao janje na klanje & $\begin{array}{c}\text { 'ne protiviti se čemu, prihvaćati što } \\
\text { neugodno bez otpora i prkosa' }\end{array}$ \\
\hline 24. ispaštati za tuđe grijehe & $\begin{array}{l}\text { 'snositi odgovornost za čiju } \\
\text { krivnju, okajavati čije prijestupe' }\end{array}$ \\
\hline 25. Judine škude (pare) & 'novac zarađen za prljave usluge' \\
\hline
\end{tabular}




\begin{tabular}{|c|c|}
\hline 26. ležati kao Lazar & 'biti ubog i napušten' \\
\hline 27. kao truba jerihonska & 'vrlo glasno, gromoglasno' \\
\hline $\begin{array}{l}\text { 28. (Ne) pada (padne) komu što } \\
<\text { kao mana > s neba }\end{array}$ & $\begin{array}{c}\text { '(ne) pada komu što bez muke i } \\
\text { truda' }\end{array}$ \\
\hline 29. Teče med i mlijeko $<$ gdje $>$. & 'blagostanje je, zemlja je izobilja' \\
\hline 30. prst Božji & $\begin{array}{c}\text { 'upozorenje s neba, Božja } \\
\text { opomena' }\end{array}$ \\
\hline 31. cjelivati komu rane & $\begin{array}{c}\text { 'tješiti koga, pomoći komu u } \\
\text { potrebi' }\end{array}$ \\
\hline $\begin{array}{l}\text { 32. mudar kao Salamun } \\
\text { (Solomun) }\end{array}$ & 'iznimno mudra i razborita osoba' \\
\hline $\begin{array}{l}\text { 33. biti čija slika i prilika (biti na } \\
\text { sliku i priliku } k o m u \text { ) }\end{array}$ & 'iznimno sličiti komu' \\
\hline 34. slovo i duh & $\begin{array}{l}\text { 'pravi smisao čega, najčešće } \\
\text { uredaba, deklaracija i zakona' }\end{array}$ \\
\hline 35. Sveto pismo & 'nešto nepovredivo' \\
\hline 36. zakopati talent u zemlju & $\begin{array}{l}\text { 'ne iskoristiti svoje prirođene } \\
\text { sposobnosti' }\end{array}$ \\
\hline 37. nevjerni Toma & 'skeptičan, sumnjičav čovjek' \\
\hline 38. vezati i driješiti & $\begin{array}{l}\text { 'odlučivati, imati posljednju riječ } \\
\text { kod odluka' }\end{array}$ \\
\hline $\begin{array}{l}\text { 39. Nije komu pala (spala) ni vlas } \\
\text { (dlaka) s glave. }\end{array}$ & 'ništa se nije (ne će) dogoditi komu' \\
\hline 40. prah i pepeo & 'ništavnost, prolaznost, uništenje' \\
\hline 41. biti zloguki prorok & $\begin{array}{c}\text { 'najavljivati nemile događaje i } \\
\text { katastrofe' }\end{array}$ \\
\hline
\end{tabular}




\begin{tabular}{|c|c|}
\hline $\begin{array}{c}\text { 42. znati koga što kao deset } \\
\text { zapovijedi }\end{array}$ & 'dobro poznavati koga što' \\
\hline 43. iščupati žito s kukoljem & 'uništiti s lošim nešto što je dobro i \\
& korisno' \\
\hline 44. živjeti životom pravednika & 'živjeti sveto i neporočno' \\
\hline
\end{tabular}


12.4. Rezultati međujezične supostavne raščlambe frazema biblijskoga podrijetla

Tablični prikaz rezultata

\begin{tabular}{|c|c|c|}
\hline $\begin{array}{c}\text { Tipovi } \\
\text { ekvivalentnosti }\end{array}$ & \multicolumn{2}{|c|}{$\begin{array}{c}\text { Udio u } \\
\text { mikrosustavu }\end{array}$} \\
\hline \multirow{2}{*}{$\begin{array}{l}\text { 1. Potpuna } \\
\text { ekvivalentnost }\end{array}$} & \multicolumn{2}{|c|}{80} \\
\hline & $\begin{array}{c}\text { tal. } \\
38,3 \%\end{array}$ & $\begin{array}{l}\text { hrv. } \\
47 \%\end{array}$ \\
\hline \multirow{2}{*}{$\begin{array}{l}\text { 2. Djelomična } \\
\text { ekvivalentnost }\end{array}$} & \multicolumn{2}{|c|}{45} \\
\hline & $\begin{array}{c}\text { tal. } \\
21,5 \%\end{array}$ & $\begin{array}{c}\text { hrv. } \\
26,5 \%\end{array}$ \\
\hline \multirow[t]{2}{*}{ 2.a. } & \multicolumn{2}{|c|}{5} \\
\hline & $2,4 \%$ & $3 \%$ \\
\hline \multirow[t]{2}{*}{ 2.b. } & \multicolumn{2}{|c|}{14} \\
\hline & $6,7 \%$ & $8,2 \%$ \\
\hline \multirow[t]{2}{*}{ 2.c. } & \multicolumn{2}{|c|}{26} \\
\hline & $12,4 \%$ & $15,3 \%$ \\
\hline \multirow{2}{*}{$\begin{array}{l}\text { 3. Semantička } \\
\text { ekvivalentnost }\end{array}$} & \multicolumn{2}{|c|}{1} \\
\hline & $\begin{array}{c}\text { tal. } \\
0,5 \%\end{array}$ & $\begin{array}{c}\text { hrv. } \\
0,6 \%\end{array}$ \\
\hline 4. Nulta & tal. 83 & hrv. 44 \\
\hline ekvivalentnost & $\begin{array}{c}\text { tal. } \\
39,7 \%\end{array}$ & $\begin{array}{c}\text { hrv. } \\
25,9 \%\end{array}$ \\
\hline
\end{tabular}




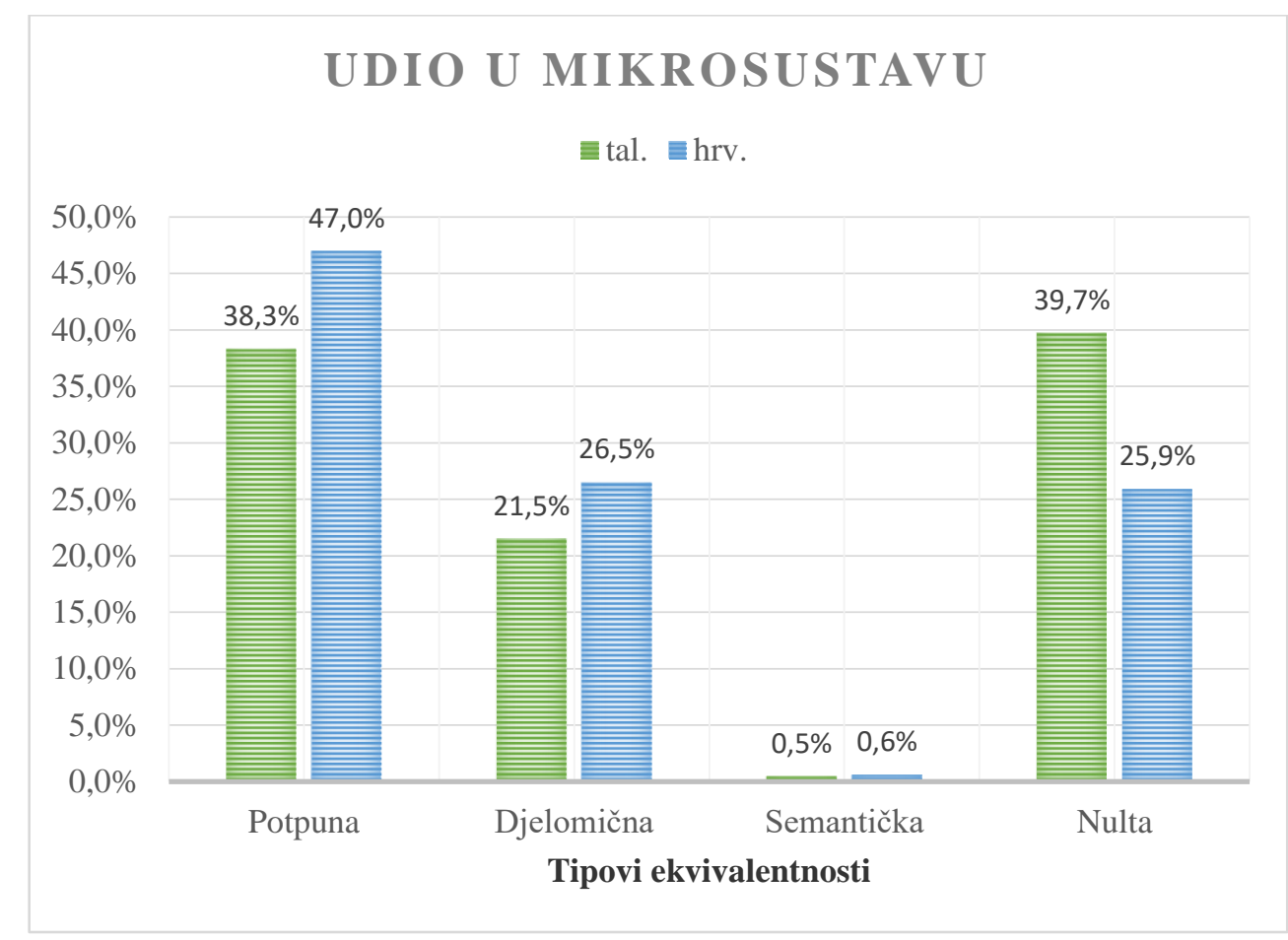

\section{Grafički prikaz rezultata}

Korpus biblijskih frazema sadrži 209 primjera u talijanskome, a 170 u hrvatskome jeziku. Premda smo napomenuli da je potpuna ekvivalentnost u međujezičnoj usporedbi najrjeđa, valja ipak zamijetiti da se pojavljuje znatan broj frazema biblijskoga podrijetla u talijanskome i u hrvatskome (80 frazema) koji imaju ne samo identičnu sliku kao temelj, nego i denotativno i konotativno značenje kao i potpunu kongruentnost u slijedu sastavnica, uz mogućnost gore spomenutih malenih razlika uvjetovanih različnošću dvaju jezika.

Budući da se i u Italiji i u krajevima nastanjenim Hrvatima, osobito od Tridentskoga sabora isključivo rabila Vulgata, latinski prijevod Biblije sv. Jeronima Dalmatinca i budući da se liturgija služila isključivo na latinskome (u hrvatskim krajevima služila se i liturgija na crkvenoslavenskome, međutim posrijedi je isti rimski obred u prijevodu na crkvenoslavenski hrvatske redakcije), određeni broj frazema biblijskoga podrijetla jednakovrijednice su u talijanskome i hrvatskome jeziku. 
Može se pretpostaviti s velikom vjerojatnošću da su i u jednome i u drugome jeziku posrijedi frazemi preuzeti izravno iz latinskoga jezika. Iako se mogućnost kalkiranja preko jezika ili narječja posrednika ne može isključiti, držimo da je to manje vjerojatno. Ti frazemi rabili su se primjerice i u krajevima koji nisu bili pod mletačkim utjecajem. No zbog zemljopisnoga položaja jednoga i drugoga naroda, kulturne povezanosti i zajedničke povijesti taj bi se utjecaj na nekim područjima frazeologije mogao očekivati. Kad su posrijedi biblijski tekstovi i liturgija, Zapadna, Latinska crkva stoljećima je inzistirala na porabi liturgijskoga jezika koji je imao veliki utjecaj na sve jezike, bilo romanske ili neromanske, u kojima su se služili obredi iz zapadne obredne skupine. Stoga postojanje znatnoga broja kongruentnih frazema u obama korpusima ne iznenađuje.

U mikrosustavu frazema biblijskoga podrijetla naišli smo na 45 primjera djelomičnih ekvivalenata koji, unatoč istomu denotativnom značenju i slici, pokazuju odstupanja u morfologiji i sintaksi ili pak u odabiru glavnih ili sporednih leksičkih sastavnica.

Premda se u međujezičnim raščlambama često polazi od pretpostavke da će najbrojniji biti tip djelomičnih ekvivalenata, to ne možemo reći za ovu raščlambu u kojoj je gotovo dvostruko više potpunih jednakovrijednica. Frazemi biblijskoga podrijetla ipak imaju određene specifičnosti u odnosu na primjerice somatske ili animalističke frazeme i takvi ishodi svakako su mogući.

Kako se dosad nije sustavno proučavala frazeologija hrvatskih narječja i nisu brojna istraživanja sa stajališta povijesne i arealne frazeologije, možemo samo nagađati jesu li postojali ranije isti ili slični frazemi u hrvatskome standardnom jeziku ili u pojedinim narječjima koji se danas smatraju zastarjelicama ili dijalektizmima. To se zacijelo ne može isključiti. Promatrajući sinkronijski presjek frazema biblijskoga podrijetla, vidljivo je da su posrijedi frazemi bez jednakovrijednica $\mathrm{u}$ drugome jeziku. Unatoč brojnim kontaktima i utjecajima oba jezika pokazuju izvornost u frazeologiji, čak i u onim područjima gdje se ponajvećma očekuju internacionalizmi i kalkovi: u frazemima biblijskoga podrijetla čiji je izvor jedan. Zbog vagabundske naravi frazema i njihova prelaženja iz jezika u jezik ne isključujemo isprepletenost s drugim nacionalnim frazeologijama u kojima bi mogle postojati jednakovrijednice nekih od ovih frazema.

Glede genetskoga i kronološkoga razvoja frazema biblijskoga podrijetla držali smo se podjele koju je napravio Földes (1990): 
1) Frazemi preuzeti izravno iz biblijskih tekstova.

2) Frazemi nastali prevođenjem biblijskih tekstova.

3) Frazemi nastali pod utjecajem biblijskih tekstova, ali nisu izravno preuzeti iz njih.

4) Frazemi nastali prema biblijskim predodžbama ili uzorcima, no bez neposrednoga odnosa prema Novome ili Starome zavjetu.

Međutim, ovdje ne možemo reći da postoje jasne granice među tim kategorijama i izravne veze s tipovima ekvivalentnosti. Mnogi frazemi izravno preuzeti iz biblijskih tekstova imaju jednakovrijednice $u$ drugome jeziku, ali također i frazemi nastali prevođenjem biblijskih tekstova ili pod njihovim utjecajem. Isto tako naići ćemo na frazeme izravno preuzete iz biblijskih tekstova u obama jezicima koji nemaju jednakovrijednice u drugome jeziku. Frazemi nastali prema biblijskim predodžbama ili uzorcima, ali bez neposrednoga odnosa prema Novome i Starome zavjetu uglavnom nemaju jednakovrijednice u drugome jeziku.

Takvomu odnosu među različitim kategorijama frazema biblijskoga podrijetla u obama jezicima pridonijela je uloga Svetoga pisma i odnos prema njemu koji je tipičan za rimokatolički svijet, gdje se prepoznaju značajne razlike od protestantskoga svijeta koji obilježava središnja uloge Biblije, čitanje i doslovno navođenje, uz manji utjecaj liturgije, sakramenata, pučkih pobožnosti itd. Valja upozoriti u ovome kontekstu i na određen odmak od biblijskih prijevoda u pravoslavnome svijetu unatoč gotovo istoj ulozi Svetoga pisma kao i u katoličanstvu. 


\section{ZAKLJUČNE NAPOMENE}

Ovim radom nastojala se popuniti praznina u supostavnoj raščlambi frazema biblijskoga podrijetla u talijanskome $\mathrm{i}$ hrvatskome jeziku te time pridonijeti razvoju kontrastivne frazeologije uopće kao i proučavanju frazema biblijskoga podrijetla koji u obama jezicima imaju snažan utjecaj, kako u prošlosti tako i danas, i u standardnome jeziku, i u regionalnim inačicama, ali i u regionalnim i lokalnim narječjima.

U okviru teorijskoga dijela rada pozabavili smo se i brojnim otvorenim pitanjima $u$ današnjoj frazeologiji, nastojeći našu polustoljetnu slavističku i kroatističku frazeološku tradiciju obogatiti promišljanjima frazeologa poglavito njemačkoga, ali i romanskoga govornog područja premda znademo da je razvoj frazeologije od samoga početka u slavistici, germanistici i romanistici posve isprepleten i mnoge ovdje razrađene koncepte obradili su naši frazeolozi i na drugi način.

Pozabavili smo se razvojem frazeologije kao (samostalne) jezikoslovne discipline te poglavito razvojem frazeologije na njemačkome govornom području, ali i u zemljama u kojima se govore romanski jezici (Romania conservata i Romania nova).

U skladu s dosadašnjim spoznajama o frazeologiji, usporedili smo različne pristupe i dali definiciju glavnih pojmova u frazeologiji: ponajprije same frazeologije, njezina mjesta unutar jezikoslovlja, odnosa prema leksikologiji te posebne povezanosti s paremiologijom. Osvrnuli smo se i na poimanje frazeologije u užemu i širemu smislu i na posljedice koje svaki pristup sa sobom nosi. U raščlambi smo se uglavnom priklonili poimanju frazeologije u širemu smislu. Opisali smo ukratko razvoj unutar frazeologije u posljednjim desetljećima i sve izraženiji interdisciplinarni pristup istraživanjima te se na poseban način osvrnuli na kontrastivnu frazeologiju koja je za ovaj rad od osobite važnosti. Definiciju i pojmovlje rasvijetlili smo na temelju modernih pristupa interlingvalnim i plurilingvalnim istraživanjima $i$ usporedbama, napose u svjetlu spoznaja interkulturalne frazeologije i holističko-integrativnoga pristupa.

Opisali smo i razvoj historijske ili povijesne frazeologije, navlastito u posljednjih desetak godina te rezultate i redefinicije koje, inače dosad zanemarivani, dijakronijski pristup proučavanju frazema sa sobom nosi te tako jasnije odredili mjesto ove raščlambe unutar današnjih frazeoloških istraživanja kako bi se njezini rezultati mogli iskoristiti i za daljnja istraživanja. 
Potom smo se pozabavili samim pojmom frazema kao temeljne jedinice u frazeologiji, različnim shvaćanjima što je frazem uopće kao i terminološkom disperzijom koja je vladala u istraživanjima i koja, osobito u nekim jezicima, ni danas nije posvema prevladana. Pojmu frazema dodali smo i pojam idioma u skladu s definicijom Haralda Burgera (2015, 14 - 15). Prema toj definiciji idiom bi bio podrazredom frazema, a svi frazemi ne moraju nužno biti idiomima te se i uporaba pojmovlja u ovome radu može shvatiti u tome svjetlu.

Nakon toga pozabavili smo se obligatnim i fakultativnim obilježjima frazema i u skladu sa spoznajama osobito njemačke frazeološke škole rasvijetlili smo četiri temeljna obilježja frazema: polileksikalnost ili višerječnost, stabilnost strukture, idiomatičnost i leksikaliziranost. Upozorili smo na važnost temeljnih obilježja frazema, osobito na kriterij višerječnosti koji je temeljem lučenja frazema od riječi, ali i na ostale kriterije u svjetlu novih spoznaja. Važno je ujedno naglasiti da u skladu s današnjim istraživanjima ostale kriterije ne treba shvaćati $u$ apsolutnome smislu i da su granice počesto fluidne i nisu čvrste kako se ranije vjerovalo. Idiomatičnost je, primjerice, prema shvaćanjima široko proširenima u okviru njemačkih frazeoloških istraživanja kriterij nužan za idiome, ali ne i za sve frazeme.

Govorili smo potom o važnosti Biblije ili Svetoga pisma za jezik i književnost europskih jezika, posebice talijanskoga i hrvatskoga te o biblijskome jeziku koji je bio osobito pogodan za razvoj frazema u mnogim europskim jezicima. Opisali smo frazeme biblijskoga podrijetla kao internacionalizme i upozorili na njihovu posebnost, osobito u zemljama sa snažnim rimokatoličkim utjecajem i tradicijom gdje se zamjećuju posve različni utjecaji u usporedbi sa zemljama u kojima su dominirali protestantski prijevodi, ali i na različitost od prijevoda $\mathrm{s}$ grčkoga i crkvenoslavenskoga. Razmotrili smo i možebitne podjele unutar slavenskoga svijeta i rasvijetlili pojam Slavia Romana kojoj hrvatski jezik jasno pripada. Pozabavili smo se također i kalkiranjem frazema.

Frazeme biblijskoga podrijetla podijelili smo na frazeme izravno preuzete iz biblijskih tekstova, frazeme nastale prevođenjem biblijskih tekstova, frazeme nastale pod utjecajem biblijskih tekstova, ali nisu izravno preuzeti iz njih i frazeme nastale prema biblijskim predodžbama ili uzorcima, no bez neposrednoga odnosa prema Novomu ili Staromu zavjetu. Upozorili smo da često nije lako odrediti granice i svrstati frazem u jednu skupinu. U korpus smo uvrstili frazeme koji pripadaju svim četirima kategorijama. Međutim, nismo uključili tzv. kristijanizme, frazeme koji su nastali pod utjecajem liturgijske prakse i običaja Crkve, kulta 
svetaca, monaškoga života, hodočašćenja i važnih događaja u Crkvi kao primjerice konklava (izbor novoga pape) koji su brojni i u talijanskome i u hrvatskome jeziku.

U drugome dijelu najprije smo pojasnili kriterije kojih smo se držali tijekom ekscerpiranja primjera.

Korpus biblijskih frazema u talijanskome jeziku sadrži 209 primjera, a u hrvatskome 170.

Supostavnoj raščlambi pristupili smo s različnih stajališta služeći se metodama Zagrebačke frazeološke škole, ali i metodama frazeologa koji pišu na njemačkome jeziku. ${ }^{107}$

Strukturna raščlamba rađena je prema trostupanjskoj podjeli. U obama korpusima prevladava frazem tipa sveze riječi, nezavisnoga i zavisnoga tipa. Naišli smo također i na primjere frazemskih rečenica. $U$ talijanskome nije pronađen nijedan primjer minimalnoga frazema, a u hrvatskome potvrđena su dva. Glede strukture frazemi biblijskoga podrijetla u talijanskome i hrvatskome pokazuju velike sličnosti bez nekih posebnih razlika.

Paradigmatičnost frazema podijelili smo na tri tipa: nultu, djelomičnu i potpunu. Frazemi nulte pragmatičnosti rijetki su jer su frazemi biblijskoga podrijetla vrlo pogodni za modifikacije. Djelomična paradigmatičnost najzastupljeniji je oblik paradigmatičnosti. Potpuna pragmatičnost puno je rjeđa u odnosu na djelomičnu.

Varijantnost je, barem u skladu s novijim istraživanjima, puno češća nego što se ranije mislilo. Da je riječ o dijakronijskome istraživanju frazema biblijskoga podrijetla ili pak o arealnome, zacijelo bi broj inačica bio mnogo veći. Svejedno, i u ovome istraživanju koje je obuhvaćalo leksikografski etablirane primjere frazema biblijskoga podrijetla standardnojezičnoga varijeteta obaju jezika potvrđeno je da 47 talijanskih frazema ili $22,5 \%$ i 55 hrvatskih frazema ili 32,4 \% ima jednu inačicu ili čak kombinaciju više inačica u jednome frazemu.

Semantička raščlamba frazema pokazala je njihovu složenost i slojevitost i potrebu različnih pristupa i opsežnih analiza da ih se opiše. U skladu s novijim spoznajama $u$ semantičkim istraživanjima $\mathrm{u}$ frazeologiji, frazeme smo podijelili po načinu čitanja prema četverostupanjskoj podjeli Haralda Burgera $(2015,64)$ i u skladu s time razmotrili motiviranost

107 Pri tome želimo naglasiti da uz brojne frazeologe njemačkoga govornog područja postoji i znatan broj frazeologa i germanista iz drugih europskih zemalja: slavenskih, germanskih i romanskih koji pišu na njemačkome jeziku i čiji su nam radovi bili od velike pomoći. 
frazema i mogućnost remotiviranja kao i semantičku autonomiju sastavnica, ali smo se dotakli i pojava kao što su polisemija, sinonimija, složenost, neodređenost i ekspresivnost i utvrdili da frazemi biblijskoga podrijetla u obama jezicima potvrđuju bogatu sinonimiju uz malen broj primjera polisemije. Frazemi toga tipa složeni su i iznimno ekspresivni, a neodređenost im omogućuje porabu u različnim stilovima i registrima. Postojanje brojnih frazema koji nemaju ekvivalente u drugome jeziku pokazuje bogatstvo nacionalne frazeologije unatoč istomu izvoru ovih frazema.

Cilj ove supostavne raščlambe bio je poglavito određivanje frazeoloških jednakovrijednica u obama jezicima. Ekvivalentnost smo podijelili na potpunu, djelomičnu, čisto semantičku i nultu, a u obzir smo uzeli i možebitne frazemske lažne parove u ovome subsustavu.

Razmjerno velik broj frazema s potpunom ekvivalentnošću ( 80 primjera) pokazuje da je najvjerojatnije riječ o jakome utjecaju istoga izvora, latinskoga prijevoda Biblije, Vulgate u obama jezicima te pripadnost istoj vjeroispovijesti ${ }^{108} \mathrm{i}$ obrednoj skupini i ne potvrđuje rezultate brojnih supostavnih analiza drugih mikrosustava u jezicima.

Broj primjera djelomične ekvivalentnosti, 45 u obama korpusima, odudara od mnogih supostavnih raščlambi frazeoloških mikrosustava dvaju ili više jezika. Ekvivalentni frazemi počesto nadmašuju broj kongruentnih, ali s obzirom na već spomenute razloge ta raspodjela ne predstavlja osobito iznenađenje.

Postoji samo jedan primjer čisto semantičke ekvivalentnosti u kojemu su zamjetne znatne leksičke i semantičke razlike, a i sama slika se razlikuje.

Oba jezika imaju također znatan broj frazema koji nemaju jednakovrijednice u drugome jeziku: 83 frazema u talijanskome i 44 u hrvatskome jeziku. To pokazuje kulturno-semantičku nepodudarnost u dvama jezicima, različne utjecaje $u$ frazeološkome blagu, ali i živost obaju jezika. Time se osobito rasvjetljuje snaga frazeologije malih naroda, čak i glede frazema koji se tradicionalno ubrajaju u internacionalizme.

\footnotetext{
108 Pripadanje istoj vjeroispovijesti ne mora nužno značiti i pripadanje istoj obrednoj skupini. Ukrajinski grkokatolici pripadaju istoj vjeroispovijesti kao i talijanski i hrvatski katolici, ali zbog bizantsko-slavenskoga obreda i Biblije na staroslavenskome mogu se očekivati drukčiji utjecaji u frazeologiji biblijskoga podrijetla. Talijanski i hrvatski katolici pripadaju istoj, zapadnoj obrednoj skupini u kojoj je dominirao rimski obred, uz postojanje i drugih obreda kao što su dominikanski, ambrozijanski, kartuzijanski itd.
} 
Snažan utjecaj i povlašteno mjesto latinskoga u liturgiji, ali i u kulturi i javnome životu obaju naroda ostavili su tragove u frazeološkome blagu kako talijanskoga tako i hrvatskoga - u svakome na poseban način - i obilježili su i druge frazeološke mikrosustave, a osobito frazeme biblijskoga podrijetla. A frazemi biblijskoga podrijetla, čija se stilska vrijednost bitno ne razlikuje, imaju i danas jak utjecaj u hrvatskome književnom i govornom jeziku, u standardnoj inačici, ali i u svim substandardnim varijetetima i bitno pridonose posebnosti hrvatskoga jezika, osobito sa stajališta kriterija identifikacije govornika, što u talijanskome nije slučaj, gdje postoji posve drukčija dinamika u odnosu na druge romanske jezike. Tek će možda dijakronijska i arealna frazeološka istraživanja rasvijetliti to bogatstvo i posebnost hrvatskoga i tisućljetnu tradiciju uporabe frazema i paremija biblijskoga podrijetla.

I ova supostavna raščlamba pokazuje svu kompleksnost frazema i glede izraza i glede sadržaja te njihovu slojevitost i nipošto ne zaziremo od promišljanja o potrebi strukturne raščlambe jezika na tri apstraktne razine, odnosno o potrebi trostruke artikulacije (usp. Burger 2005, 32) kako bi se ozbiljnije shvatila i temeljitije istražila frazeologija europskih jezika, ali i analitički strože pristupilo izraženijem zanimanju za sveze riječi koje se ćuti u jezikoslovlju u posljednjim desetljećima. 


\section{POPIS LITERATURE}

Archangel'skij, V. (1972). O zadačah, ob-ektach, razdelach russkoj frazeologii kak lingvističeskoj discipliny. U: Problemy ustojčivosti i variantnosti frazeologičeskich edinic. Tula.

Babić, Stjepan. (1989). Sinkronija i dijakronija u tvorbi riječi. Jezik 37, 1, str. 1 - 32.

Balaş, Oana-Dana; Gebăilă, Anamaria; Voicu, Roxana. (2019). Fraseologia e paremiologia: prospettive evolutive, pragmatica e concetualizzazione. Riga (Letonia): Edizioni Accademiche Italiane (Omniscriptum Group).

Bally, Charles. (1909). Traité de stylistique française. Heidelberg: C. Winter.

Barz, Irmhild. (1992). Phraseologische Varianten. Begriff und Bedeutung. U: Deutsche Phraseologie, str. 25-47.

Beccaria, Gian Luigi. (1999). Sicuterat. Il latino di chi non lo sa: Bibbia e liturgia nell'italiano e nei dialetti. Milano: Garzanti.

Benigni, Valentina. (2012). I binomi coordinativi in russo: un'analisi costruzionista. mediAzioni 13.

Benucci i dr. (2018). Fraseologia, paremiologia e lessicologia. Roma: Topoi.

Bezić, Maja; Kalebić, Lovorka. (2015). Gli italianismi nella fraseologia dialettale croata: il caso della parlata di Spalato. U: Quaestiones romanicae III.

Bibbia. (1997). Milano: Edizioni San Paolo.

Bibel. (1991). Augsburg: Pattloch.

Biblija. (1987). Zagreb: Kršćanska sadašnjost. 
Biblija. (2008). Zagreb; Sarajevo; Split: Hrvatsko biblijsko društvo; Vrhbosanska nadbiskupija; Verbum.

Bierich, Alexander. (2014). Phänomene der historischen Phraseologie der slawischen Sprachen. U: Gutschmidt, Karl i dr. (ur.). Die slawischen Sprachen. Ein internationales Handbuch zu ihrer Struktur, ihrer Geschichte und ihrer Erforschung. Band 2. Berlin Munich - Boston: de Gruyter, str. 1776 - 1793.

Böhmer, Heiner. (1997). Ist Phraseologie heute noch als einheitliches Gebiet haltbar? U: Sabban, Annette (ur.). Phraseme im Text: Beiträge aus romanistischer Sicht. Bochum, str. $1-28$.

Botica, Stipe. (1995). Biblija i hrvatska kulturna tradicija. Zagreb: Vlastita naklada.

Bralić, Snježana. (2011). Sulla motivazione e sulla grammatica dei modi di dire in italiano. U: Zbornik radova Filozofskoga fakulteta u Splitu 4, str. 171 - 183.

Budimir, Irina. (2020). Frazemi prve hercegovačke hrvatske periodike na prijelazu iz 19. u 20. stoljeće i njihova leksikografska obradba. Mostar: Fram Ziral.

Budimir, Irina; Mišetić, Damir. (2020). Utjecaj ograničenja prominentnosti slogova na slijed sastavnica binoma u talijanskome i hrvatskome jeziku. U: Identiteti - kulture - jezici. Novi obzori društvenih i humanističkih znanosti. Mostar: Filozofski fakultet Sveučilišta u Mostaru, str. 64 - 77.

Burger, Harald. (1973). Idiomatik des Deutschen. Germanistische Arbeitshefte 16. Tübingen: Niemeyer.

Burger, Harald. (2005). 30 Jahre germanistische Phraseologieforschung. Hermes, Journal of Linguistics, 35 .

Burger, Harald. (2012). Alte und neue Fragen, alte und neue Methoden der historischen Phraseologie. U: Burger, Harald i dr. (ur.). Aspekte der historischen Phraseologie und Phraseographie. Heidelberg: Universitätsverlag Winter, str. 1 - 20. 
Burger, Harald. (2015). Phraseologie - Eine Einführung am Beispiel des Deutschen. Berlin: Erich Schmidt Verlag.

Burger, Harald; Buhofer, Annelies; Sialm, Ambros. (1982). Handbuch der Phraseologie. Berlin - New York: De Gruyter.

Burger, Harald; Dobrovol'skij, Dmitrij; Kühn, Peter; Norrick, Neal R. (2007). Phraseologie. Berlin - New York: De Gruyter.

Burger, Harald i dr. (ur.). (2012). Aspekte der historischen Phraseologie und Phraseographie. Heidelberg: Universitätsverlag Winter.

Casadei, Federica. (1996). Metafore ed espressioni idiomatiche. Roma: Bulzoni Editore.

Casadei, Federica. (2017). Breve dizionario di linguistica. Roma: Carocci editore.

Chrissou, Marios. (2000). Kontrastive Untersuchungen $\mathrm{zu}$ deutschen und neugriechischen Phraseologismen mit animalistischer Lexik. Essen: Clemon-Verlag.

Corpas Pastor, Gloria. (2003). Acerca de la (in) traducibilidad de la fraseología. U: Corpas Pastor, Gloria (ur.). Diez años de investigación en fraseología: análisis sintáctico-semánticos, contrastivos y traductológicos. Madrid: Iberoamericana, str. 275 -310 .

Corpas Pastor, Gloria; Mena Martínez Florentina. (2003). Aproximación a la variabilidad fraseológica de las lenguas alemana, inglesa y española. ELUA, 17, str. 181 -201 .

Černyševa, Irina Ivanovna. (1970). Frazeologija sovremennogo nemeckogo jazyka. Moskva: Izd.Vysš. Škola.

Černyševa, Irina Ivanovna. (1980). Variabilität in Sprachsystem, und Text auf lexikalischphraseologischer Ebene. U: Phonetik, Sprachwissenschaft und Kommunikations-forschung 33, str. $307-310$. 
Černyševa, Irina Ivanovna. (1984). Aktuelle Probleme der deutschen Phraseologie. Deutsch als Fremdsprache. 21/1, str. $17-22$.

De Giovanni, Cosimo. (2017). Introduzione. U: De Giovanni, Cosimo (ur.). Fraseologia e Paremiologia. Passato, presente, futuro. Milano: FrancoAngeli, str. 13 - 14.

Di Natale, Francesco; Zacchei, Nadia. (1996). In bocca al lupo! Espressioni idiomatiche e modi di dire tipici della lingua italiana. Perugia: Guerra Edizioni.

Dobrovol'skij, Dmitrij. (1995). Kognitive Aspekte der Idiom-Semantik. Studien zum Thesaurus deutscher Idiome. Tübingen.

Dobrovol'skij, Dmitrij; Piirainen, Elisabeth. (1997). Symbole in Sprache und Kultur. Studien zur Phraseologie aus kultursemiotischer Perspektive. Bochum.

Donalies, Elke. (2009). Basiswissen, Deutsche Phraseologie. Tübingen.

Dräger, Marcel. (2012). Plädoyer für eine diachrone Perspektive in der Phraseographie. U: Burger, Harald i dr. (ur.). Aspekte der historischen Phraseologie und Phraseographie. Heidelberg: Universitätsverlag Winter, str. 193 - 226.

Duda, Bonaventura. (1987). Opći uvod u Bibliju, Uvodi i napomene uz knjige Staroga zavjeta i Uvodi i napomene uz knjige Novoga zavjeta. U: Biblija. Zagreb: Kršćanska sadašnjost, str.1169 - 1273.

Duhme, Michael. (1995). Lauschangriff und Rollkommando „Einwortphraseologismen" in der Pressesprache am Beispiel des Nachrichtenmagazins FOCUS. U: Baur, Ruprecht S.; Closta, Christoph (ur.). Von der Einwortmetapher zur Satzmetapher. Studien zur Phraseologie und Parömiologie. Bochum: Brockmayer, str. $83-93$.

Eckert, Rainer. (1976). Aktuelle Probleme der Phraseologieforschung. U: Aktuelle Probleme der Phraseologie. Materialien der wissenschaftlichen Konferenz des Wissenschaftsgebiets Ostslawische Sprachwissenschaft der Sektion Theoretische und 
angewandte Sprachwissenschaft. Leipzig, am 13. und 14. November 1975. Karl-MarxUniversität Leipzig, str. $7-27$.

Fanfani, Massimo. (2007). Phraseographie des Italienischen. U: Burger, Harald; Dobrovol'skij, Dmitrij; Kühn, Peter; Norrick, Neal R. Phraseologie. Berlin - New York: De Gruyter, str. 975 - 986.

Farø, Ken. (2004). Wann geht man über den Fluss, um Wasser zu holen? Idiomatische Äquivalenzprobleme in Lexikologie und Lexikographie. LexicoNordica 11, str. 85 108.

Farø, Ken. (2015). Feste Wortgruppen / Phraseologie II: Phraseme. U: Haß, Urlike. Storjohann, Petra (ur.). Handbuch Wort und Wortschatz. Berlin - Boston: De Gruyter. str. $226-247$.

Filatkina, Natalia. (2012). Historische Phraseologie in älteren deutschen Texten. U: Burger, Harald i dr. (ur.). Aspekte der historischen Phraseologie und Phraseographie. Heidelberg: Universitätsverlag Winter, str. $21-44$.

Filipović Petrović, Ivana. (2018). Kada se sretnu leksikografija i frazeologija. O statusu frazema u rječniku. Zagreb: Srednja Europa.

Fink-Arsovski, Željka. (2002). Poredbena frazeologija: pogled izvana i iznutra. Zagreb: FF press.

Fink-Arsovski, Željka. (2015). Hrvatsko-romansko-germanski rječnik poredbenih frazema. Zagreb: Knjigra.

Fink-Arsovski, Željka. (2016). Što čini razliku? Tri novija frazeološka kalka u hrvatskom jeziku. U: Slavenska filologija. Prilozi jubileju prof. em. Milenka Popovića. Zagreb: FF press.

Fleischer, Wolfgang. (1982). Phraseologie der deutschen Gegenwartssprache. Leipzig: VEB Bibliographisches Institut. 
Fleischer, Wolfgang. (1997). Phraseologie der deutschen Gegenwartssprache. Tübingen: Max Niemeyer Verlag.

Földes, Czaba. (1990). Die Bibel als Quelle phraseologischer Wendungen: dargestellt am Deutschen, Russischen und Ungarischen. U: Proverbium. Wearbook of International Proverb Scholarship. The University of Vermont 7, str. $57-75$.

Földes, Czaba. (1997). Konzepte der kontrastiven Phraseologie. U: Korhonen, Jarmo; Gimpl, Georg (ur.). Kontrastiv. Helsinki: Finn Lectura.

Földes, Csaba. (2006). Deutsche Phraseologie kontrastiv: Intra- und interlinguale Zugänge. Heidelberg: Julius Groos Verlag.

Franceschi, Temistocle. (2017). Il proverbio strumento di comunicazione. La paremiologia territoriale o geoparemiologia: 1'Atlante Paremiologico Italiano (API). U: De Giovanni, Cosimo (ur.). Fraseologia e Paremiologia. Passato, presente, futuro. Milano: FrancoAngeli, str. 17 - 30.

Giacoma, Luisa. (2017). Frasi fatte e...disfatte: il progetto Emergenza Italiano su espressioni idiomatiche e didattica. U: De Giovanni, Cosimo (ur.). Fraseologia e Paremiologia. Passato, presente, futuro. Milano: FrancoAngeli, str. 411 - 426.

Glovacki-Bernardi, Zrinjka (ur.). (2001). Uvod u lingvistiku. Zagreb: Školska knjiga.

Gréciano, Gertrud. (1983). Forschungen zur Phraseologie. Zeitschrift für germanistische Linguistik, 11/2, str. $232-243$.

Hallsteinsdóttir, Erla. (2006). Phraseographie. Hermes, Journal of Language and Communication Studies 36, str. 91 - 128.

Hallsteinsdóttir, Erla. (2011). Aktuelle Forschungsfragen der deutschsprachigen Phraseodidaktik. Linguistik online 47, 3/11. 
Hallsteinsdóttir, Erla. (2014). Interkulturelle Phraseologie. U: Jesenšek, Vida; Dobrovol'skij, Dimitrij (ur.). Phraseologie und Kultur (Phraseology and culture). Maribor: Mednarodna založba Oddelka za slovanske jezike in književnosti, Filozofska fakulteta.

Hallsteinsdóttir, Erla; Farø, Ken. (2006). Neue theoretische und methodische Ansätze in der Phraseologieforschung / New Theoretical and Methodological Approaches to Phraseology. Linguistik online, 27.

Hallsteinsdóttir, Erla; Farø, Ken. (2010). Interlinguale Phraseologie: Theorie, Praxis und Perspektiven. Yearbook of Phraseology, str. 125 - 159.

Häusermann, Jürg. (1977). Phraseologie. Hauptprobleme der deutschen Phraseologie auf der Basis sowjetischer Forschungsergebnisse. Tübingen: Niemeyer.

Hessky, Regina. (1987). Phraseologie. Linguistische Grundfragen und kontrastives Modell deutsch-ungarisch. Tübingen: Niemeyer.

Henschel, Helgunde. (1993). Die Phraseologie der tschechischen Sprache. Frankfurt am Main: Peter Lang.

Higi-Wydler, Melanie. (1989). Zur Übersetzung von Idiomen. Eine Beschreibung und Klassifizierung deutscher Idiome und ihrer französischen Übersetzungen. Frankfurt am Main: Verlag Lang.

Hudaček, L; Mihaljević, M; Pilić, J. (2001). Frazemi. U: Hrvatski jezik IV. Zagreb: Profil, str. $85-89$.

Jelaska, Zrinka. (2014). Animalistički frazemi biblijskoga podrijetla u hrvatskome i drugim slavenskim jezicima. U: Vidović Bolt, Ivana (ur.). Životinje u frazeološkom ruhu: zbornik radova s međunarodnoga znanstvenoga skupa Animalistički frazemi u slavenskim jezicima. Zagreb: FF press. 
Jernej, Josip. (1982a). Fraseologia in chiave contrastiva: con esemplificazione italiana, serbocroata e tedesca. Roma: Bulzoni.

Jernej, Josip. (1982b). Interferencije na području frazeologije. Strani jezici: časopis za unapređenje nastave stranih jezika, 11, 1-2, str. $13-16$.

Jernej, Josip. (1992 / 1993). O klasifikaciji frazema. Filologija 20 - 21, str. 191 - 197.

Jernej, Josip. (1996). Bilješke oko podrijetla naše frazeologije. Suvremena lingvistika $22,1-2$, str. $265-269$.

Jerolimov, Ivana. (2001). Frazemi sa somatskom sastavnicom na primjeru talijanskohrvatske frazeologije. Suvremena lingvistika $51-52,1-2$, str. $87-99$.

Kaštelan, Jure. (1987). Uvod. U: Biblija. Kršćanska sadašnjost. Zagreb, str. V - VI.

Katičić, Radoslav. (1992). Novi jezikoslovni ogledi. Zagreb: Školska knjiga.

Katičić, Radoslav. (1999). Na kroatističkim raskrižjima. Zagreb: Sveučilište u Zagrebu - Hrvatski studiji.

Katičić, Radoslav. (2013). Hrvatski jezik. Zagreb: Školska knjiga.

Keil, Martina. (1997). Wort für Wort - Repräsentation und Verarbeitung verbaler Phraseologismen (Phraseo-Lex). Tübingen.

Kolenić, Ljiljana. (1992 - 1993). Pogled u frazeologiju Kanižlićeve „Rožalije“. Filologija $20-21$, str. $215-219$.

Kolenić, Ljiljana. (1994). Izradba frazeoloških rječnika djela slavonskih pisaca 18. stoljeća. Filologija $22-23$, str. $51-58$.

Kolenić, Ljiljana. (1996). Frazemi u Habdelićevu dikcionaru. Filologija 27, str. 53 - 61. 
Kolenić, Ljiljana. (1997). Frazemi u Belostenčevu Gazofilaciju. SL 43/44, str. 117 130.

Kolenić, Ljiljana. (1998). Frazemi u rječnicima Jurja Habdelića i Ivana Belostenca. Filologija $30-31$, str. $47-54$.

Kolenić, Ljiljana. (1999). Kako prepoznati frazem. U: Badurina, Lada i dr. (ur.). Teorija i mogućnosti primjene pragmalingvistike. Zagreb; Rijeka: Hrvatsko društvo za primijenjenu lingvistiku, str. $377-382$.

Koller, Werner. (1979). Einführung in die Übersetzungswissenschaft. Heidelberg: Quelle \& Mayer.

Komenda-Earle, Barbara. (2009). Zur Frage der Äquivalenz, Konvergenz und Bildaffinität. Am Beispiel von deutschen Somatismen mit der lexikalischen Komponente ,Finger' und ihren polnischen Entsprechungen. U: Bartoszewicz, Iwona; Hałub, Marek; Tomiczek, Eugeniusz (ur.). Argumente - Profile - Synthesen. Germanica Wratislaviensia 129. Wrocław 2009., str. 61 - 82.

Konecny, Christine. (2014). Unikale Lexeme - ,Spuren“ der Diachronie in der Synchronie? Eine Analyse anhand ausgewählter italienischer Phraseologismen. U: Melchior, L.; Göschl, A.; Fischer, M.; Voigt, A. (ur.). Spuren.Suche (in) der Romania. Beiträge zum XXVIII. Forum Junge Romanistik in Graz (18. - 21. 4. 2012.). Frankfurt am Main: Peter Lang, str. 283 - 298.

Korhonen, Jarmo. (1991). Konvergenz und Divergenz in deutscher und finnischer Phraseologie. Zugleich ein Beitrag zur Erläuterung der Verbreitung und Entlehnung von Idiomen. U: Palm, Christine (ur.). EUROPHRAS 90. Akte der internationalen Tagung zur germanistischen Phraseologieforschung. Aske / Schweden 12. - 15.9.1990, Uppsala, str. 123 - 137.

Korhonen, Jarmo. (2002). Typologien der Phraseologismen: Ein Überblick. U: D., Alan Cruse i dr. (ur.). Lexikologie. Ein internationales Handbuch zur Natur und Struktur von 
Wörtern und Wortschätzen (Handbücher zur Sprach- und Kommunikationswissenschaft 21.1). Berlin - New York: De Gruyter, str. $402-407$.

Korhonen, Jarmo. (2007). Probleme der kontrastiven Phraseologie. U: Burger, Harald; Dobrovol'skij, Dmitrij; Kühn, Peter; Norrick, Neal R. Phraseologie. Berlin - New York: De Gruyter, str. $574-589$.

Kovačević, Barbara. (2012). Hrvatski frazemi „od glave do pete”. Zagreb: Institut za hrvatski jezik i jezikoslovlje.

Kovačević, Barbara; Ramadanović, Ermina. (2013). Frazemske polusloženice (od rječnika preko tvorbe do pravopisa i obratno). Rasprave: časopis Instituta za hrvatski jezik i jezikoslovlje 39/1, str. $271-291$.

Kühn, Peter. (2007). Phraseologie des Deutschen: Zur Forschungsgeschichte. U: Burger, Harald; Dobrovol'skij, Dmitrij; Kühn, Peter; Norrick, Neal R. Phraseologie. Berlin - New York: De Gruyter.

Lengert, Joachim. (2007). Phraseographie des Französischen. U: Burger, Harald; Dobrovol'skij, Dmitrij; Kühn, Peter; Norrick, Neal R. Phraseologie. Berlin - New York: De Gruyter, str. 958 - 974.

Lewicki, A. M.; Pajdzińska, A. (2001). Frazeologia. U: Bartmiński, J. (ur.). Współczesny język polski. Lublin, str. 315 - 333.

Lombardi Vallauri, Edoardo. (2013). La linguistica. Bologna: il Mulino.

Luque Nadal, Lucía. (2010). Las referencias bíblicas en inglés y en español. Estudio curturológico - contrastivo. Odisea 11, str. $269-283$.

Lurati, Ottavio. (1998). Modi di dire. Nuovi percorsi interpretativi. Varese: Macchione Editore / Fondazione Ticino Nostro.

Lurati, Ottavio. (2001). Dizionario dei modi di dire. Milano: Garzanti. 
Lurati, Ottavio. (2002). Per modo di dire... Storia della lingua e antropologia nelle locuzioni italiane ed europee. Bologna: Cooperativa Libraria Universitaria Editrice Bologna (CLUEB).

Lurati, Ottavio. (2007). Historische Phraseologie des Italienischen. U: Burger, Harald; Dobrovol'skij, Dmitrij; Kühn, Peter; Norrick, Neal R. Phraseologie. Berlin - New York: De Gruyter, str. $1126-1134$.

Ljubičić, Maslina. (1994). O hrvatskim zoonimima: konotativno značenje i frazeologija. Filologija $22-23$.

Ljubičić, Maslina. (2009). Sui metaplasmi delle parole croate nel dialetto veneto. Studia Romanica et Anglica Zagrabiensia, 54 (-), str. 83 - 110.

Ljubičić, Maslina. (2011). Posuđenice i lažni parovi. Zagreb: FF press.

Ljubičić, Maslina. (2014). Leksem riba u frazeologiji hrvatskoga i drugih europskih jezika. U: Vidović Bolt, Ivana (ur.). Životinje u frazeološkom ruhu. Zagreb: FF press, str. $1-18$.

Ljubičić, Maslina; Kovačić, Vinko. (2008). Alcuni ittionimi nella fraseologia croata. U: María Álvarez de la Granja (ur.). Lenguaje figurado y motivación. Una perspectiva desde la fraseología. Frankfurt am Main: Peter Lang, str. 191 - 207.

Maček, Dora. (1992 - 1993). Neka pitanja o definiciji idiomatskih fraza. Filologija 20 -21, str. $263-276$.

Masini, Francesca. (2006). Binomi coordinati in italiano. U: Cresti, E. (ur.). Prospettive nello studio del lessico italiano. Firenca: Atti SILFI, str. 563 - 571.

Matasović, Ranko. (2002). Uvod u poredbenu lingvistiku. Zagreb: Matica hrvatska. 
Matešić, Josip. (1978). O poredbenom frazemu u hrvatskom jeziku. Filologija 8, str. $221-218$.

Matešić, Josip. (1982). Frazeološki rječnik hrvatskoga ili srpskoga jezika. Zagreb: Školska knjiga.

Matešić Josip i dr. (1988). Hrvatsko-njemački frazeološki rječnik. Zagreb: Nakladni zavod Matice hrvatske. München: Verlag O. Sagner.

Matešić, Josip. (1995). Frazeologija i dijalektologija. U: Hrvatski dijalektološki zbornik 9. Zagreb, str. $83-88$.

Matešić, Josip. (1996). Frazeologija u djelu Frana Kurelca. Riječki filološki dani I, str. $173-179$.

Meisinger, Bogdan. (1997). Hrvatska frazeologija kao kulturno-antropološki fenomen. Riječ - časopis za filologiju.

Melvinger, Jasna. (1989). Frazeologija. U: Leksikologija. Osijek: Pedagoški fakultet, str. $129-135$.

Mellado Blanco, Carmen. (2000). Formas estereotipadas de realización no verbal en alemán y español: los cinegramas desde un enfoque contrastivo-histórico. U: Corpas Pastor, Gloria (ur.). Las lenguas de Europa: estudios de fraseología, fraseografía y traducción. Granada: Editorial Comares, str. 389 - 410.

Mellado Blanco, Carmen. (2017). Locuciones y proverbios de origen bíblico: creación y difusión em alemán y español. Revista de Letras 36, str. 52 - 69.

Menac, Antica. (1970 / 1971). O strukturi frazeologizma. Jezik, 1. Hrvatsko filološko društvo, $1-4$.

Menac, Antica. (1978). Neka pitanja u vezi s klasifikacijom frazeologije. Filologija 8, str. $219-226$. 
Menac, Antica. (1991). Frazeologija Hektorovićeva „Ribanja i ribarskog prigovaranja“. Senj zb. 18, str. $101-107$.

Menac, Antica. (1992). Frazeologija Mažuranićeve Smrti Smail-age Čengića. Forum 1 -2 , str. $261-269$.

Menac, Antica. (2007). Hrvatska frazeologija. Zagreb: Knjigra.

Menac, Antica; Fink-Arsovski, Željka; Venturin, Radomir. (2014). Hrvatski frazeološki rječnik. Zagreb: Naklada Ljevak.

Menac, Antica; Vučetić, Zorica. (1995). Hrvatsko-talijanski frazeološki rječnik, II. izd., Mali frazeološki rječnici, 10. Zagreb: Zavod za lingvistiku Filozofskog fakulteta, str. 1 $-123$.

Menac Antica; Menac-Mihalić, Mira. (1997). Elementi venecijanskog dijalekta u frazeologiji suvremenih bračkih čakavskih pjesnika. Riječ, časopis za filologiju 3, 2, str. $54-58$.

Menac-Mihalić, Mira. (2005). Frazeologija novoštokavskih ikavskih govora u Hrvatskoj s rječnikom frazema i značenjskim kazalom s popisom sinonimnih frazema. Zagreb: Institut za hrvatski jezik i jezikoslovlje / Školska knjiga.

Mišetić, Damir. (2018). Slijed sastavnica binoma u talijanskome i hrvatskome jeziku. Hum 13, 20, str. $308-325$.

Moguš, Milan. (1990). O Marulićevoj frazeologiji u „Juditi“. Wiener slawistisches Jahrbuch 8, str. $157-161$.

Moguš, Milan; Menac, Antica. (1989). Frazeologija Gundulićeva „Osmana“. Forum 7 -8 , str. $192-201$.

Mokienko, Valerij M. (2002). Prinzipien einer historisch-etymologischen Analyse der Phraseologie. U: Hartmann, Dietrich; Wirrer, Jan (ur.). Wer A sägt, muss auch B sägen. 
Beiträge zur Phraseologie und Sprichtwortforschung aus dem Westfälischen Arbeitskreis. Baltmannsweiler, str. $231-254$.

Mokienko, Valerij M. (2009a). Phraseologie. U: Kempgen, Sebastian i dr. (ur.). Die slawischen Sprachen. Teilband 1. Ein internationales Handbuch zu ihrer Struktur, ihrer Geschichte und ihrer Erforschung. Berlin: de Gruyter, str. 792 - 802.

Mokienko, Valerij M. (2009b). Phraseologische Einheiten. U: Kempgen, Sebastian i dr. (ur.). Die slawischen Sprachen. Teilband 1. Ein internationales Handbuch zu ihrer Struktur, ihrer Geschichte und ihrer Erforschung. Berlin: de Gruyter, str. 802 - 809.

Muhvić-Domanovski, Vesna. (1992 - 1993). Neki problemi prezentacije frazeologizama u frazeološkim i općim rječnicima. Filologija 20 - 21, str. 323 - 329.

Müller, Gereon. (1997). Beschränkungen für Binomialbildung im Deutschen. Zeitschrift für Sprachwissenschaft 16, str. $5-51$.

Nigoević, Magdalena. (2007). Romanizmi u Berekinu. Knjižnica Bašćina, knjiga 6. Split: Hrvatsko kulturno društvo Napredak.

Nuccorini, Stefania. (2007). Italian phraseology. U: Burger, Harald; Dobrovol'skij, Dmitrij; Kühn, Peter; Norrick, Neal R. Phraseologie. Berlin - New York: De Gruyter, str. $691-703$.

Opašić, Maja. (2010). Hrvatski i talijanski frazemi: podudarnosti i razlike. U: Badurina, L.; Bačić Karković, D. (ur.). Riječki filološki dani: zbornik radova sa 6 . međunarodnoga znanstvenog skupa. Rijeka: Filozofski fakultet.

Opašić Maja; Spicijarić Paškvan, Nina. (2010). Prilog kontrastivnoj analizi frazema sa sastavnicom boje u hrvatskoj, talijanskoj i njemačkoj frazeologiji. Fluminensia: časopis za filološka istraživanja 22, str. $121-136$.

Opašić Maja; Spicijarić Paškvan, Nina. (2011). Holonim ruka i njegovi meronimi kao sastavnice hrvatskih i talijanskih frazema. Suvremena lingvistika 37. 
Opašić, Maja. (2013). Biblizmi u hrvatskome jeziku. Doktorski rad. Zagreb: Filozofski fakultet Sveučilišta u Zagrebu.

Opašić, Maja. (2014). Mogućnosti deonimizacije i apelativizacije biblijskih onima u hrvatskome jeziku. U: Zbornik radova Riječki filološki dani 9 / Stolac, Diana (ur.). Rijeka: Filozofski fakultet Sveučilišta u Rijeci, str. 501 - 510.

Opašić, Maja; Čunović, Nika; Fumić, Mateja. (2014). Bogatstvo i siromaštvo u hrvatskoj frazeologiji. Fluminensia: časopis za filološka istraživanja 26, str. 91 - 103.

Palermo, Massimo. (2015). Linguistica italiana. Bologna: Il Mulino.

Palm, Christine. (1994). Habent sua fata idiomata. Beobachtungen zur Polysemie von Phraseologismen. U: SANDIG, B. (ur.). Tendenzen der Phraseologieforschung. Bochum: Europhras, str. $431-460$.

Palm, Christine. (1997). Phraseologie. Eine Einführung. Tübingen: Narr.

Pamies, Antonio. (2007). Spanish phraseography. U: Burger, Harald; Dobrovol'skij, Dmitrij; Kühn, Peter; Norrick, Neal R. Phraseologie. Berlin - New York: De Gruyter.

Petrač, Božidar. (1994). Biblija i hrvatska književnost. Književna smotra, XXVI/92 94. Zagreb, str. $185-196$.

Picchio, Riccardo. (1991). Letteratura della Slavia ortodossa. Bari: Edizioni Dedalo.

Piirainen, Elisabeth. (2006). Phraseologie in arealen Bezügen: ein Problemaufriss. Linguistik online 9, 27, str. $195-218$.

Piirainen, Elisabeth. (2008). Phraseologie und Areallinguistik: ein interdisziplinärer Forschungsansatz. Das Wort. Germanistisches Jahrbuch, XIX - XX. 
Piirainen, Elisabeth. (2012a). Widespread Idioms in Europe and Beyond. New York: Peter Lang Publishing.

Piirainen, Elisabeth. (2012b). Idioms from a historical etymological perspective: Benefit for cross-linguistic studies? U: Burger, Harald i dr. (ur.). Aspekte der historischen Phraseologie und Phraseographie. Heidelberg: Universitätsverlag Winter, str. $167-179$.

Piirainen, Elisabeth. (2016). Lexicon of Common Figurative Units: Widespread Idioms in Europe and Beyond. Volume II. New York: Peter Lang Publishing.

Pilz, Klaus Dieter. (1981). Phraseologie: Redensartenforschung. Stuttgart: Metzler.

Pittano, Giuseppe. (2014). Dizionario dei modi di dire. Bologna: Zanichelli editore.

Polivanov, Evgenij Dmitrievič. (1931). Za marksistskoe jazykoznanie. Moskva.

Pranjković, Ivo. (2006). Hrvatski jezik i biblijski stil. Raslojavanje jezika i književnosti. U: Bagić, Krešimir (ur.). Zbornik radova 34. seminara Zagrebačke slavističke škole. Zagreb: FF press, str. $23-32$.

Proost, Kristel. (2007). Paradigmatic relations of phrasemes. U: Burger, Harald; Dobrovol'skij, Dmitrij; Kühn, Peter; Norrick, Neal R. Phraseologie. Berlin - New York: De Gruyter, str. 110 - 119 .

Rajchštejn, Aleksandr D. (1980). Sopostavitel’nyj analiz nemeckoj-russkoj frazeologii [Kontrastive Analyse der Phraseologie im Deutschen und Russischen]. Moskva.

Renzi, Lorenzo; Andreose, Alvise. (2015). Manuale di linguistica e filologia romanza. Bologna: Il Mulino.

Ribarova, Slavomira; Vidović Bolt, Ivana. (2009). Biblijski zoonimski frazemi u hrvatskom, češkom i poljskom jeziku. U: Sesar, Dubravka (ur.). Slavenski jezici u usporedbi s hrvatskim I. Zagreb: FF press. 
Richter-Vapaatalo, Ulrike. (2007). Da hatte das Pferd die Nüstern voll. Gebrauch und Funktion von Phraseologie im Kinderbuch. Frankfurt. A. M.

Rothkegel, Annely. (1973). Feste Syntagmen. Grundlagen, Strukturbeschreibung und automatische Analyse (= Linguistische Arbeiten 6). Tübingen: Niemeyer.

Ruiz Gurillo, Leonor. (1997). Aspectos de fraseología teórica española. Valencia: Universidad.

Sabitova, M. (1976). Untersuchungen zur Struktur und Semantik phraseologischer Lexemverbindungen in der deutschen Gegenwartssprache. Diss. A. Leipzig.

Samardžija, Marko. (1995). Frazem. U: Leksikologija s poviješću hrvatskoga jezika u XX. stoljeću. Zagreb: Školska knjiga, str. 83 - 86.

Simone, Raffaele. (2011). Fondamenti di linguistica. Milano: McGraw-Hill.

Schindler, Christina. (2004). Untersuchungen zur Äquivalenz von Idiomen in Sprachsystem und Kontext. Münster: Verlag Münster.

Sciutto, Virginia. (2005). Unidades fraseológicas: un análisis contrastivo de los somatismos del español de Argentina y del italiano. AISPI. Actas XIII.

Schwarz-Friesel, Monika. (2007). Sprache und Emotion. Tübingen - Basel: A. Francke Verlag.

Sensini, Marcello. (1997). Gli strumenti linguistici. Per una didattica modulare della lingua italiana. Milano: Arnoldo Mondadori Scuola.

Sorge, Paola. (1997). Dizionario dei modi di dire della lingua italiana. Roma: Newton \& Compton editori. 
Stolac, Dijana. (1994). Boje u starijoj hrvatskoj frazeologiji i leksikografiji. Filologija $22-23$, str. $259-267$.

Tafra, Branka. (1996). Bliskoznačni odnosi u leksiku. Filologija 26, str. 73 - 83.

Tekavčić, Pavao. (1979). Uvod u lingvistiku. Zagreb: Liber.

Tekavčić, Pavao. (1988). O jednom tipu dvočlanih složenica u hrvatskom ili srpskom i talijanskom jeziku. Filologija 16, str. $145-150$.

Teubert, Wolfgang. (2004). Feste Wortverbindungen in ein- und mehrsprachiger Sicht. U: Czicza, Dániel; Hegedűs, Ildikó; Kappel, Péter; Németh, Attila (ur.). Wertigkeiten, Geschichten und Kontraste. Festschrift für Péter Bassola zum 60. Geburtstag. Szeged, str. $521-547$.

Thun, Harald. (1978). Probleme der Phraseologie. Untersuchungen zur wiederholten Rede mit Beispielen aus dem Französischen, Italienischen, Spanischen und Rumänischen. Tübingen: Niemeyer.

Trask, Robert Lawrence. (2005). Temeljni lingvistički pojmovi. Zagreb: Školska knjiga.

Turk, Marija. (1994). Naznake o podrijetlu frazema. Fluminensia 6, 1-2, str. 37 - 47.

Turk, Marija. (2013). Jezično kalkiranje u teoriji i praksi: prilog lingvistici jezičnih dodira. Zagreb - Rijeka: Hrvatska sveučilišna naklada - Filozofski fakultet.

Turk, Marija; Opašić, Maja. (2008). Supostavna raščlamba frazema. Fluminensia 20, 1, str. $19-31$.

Turk, Marija; Spicijarić Paškvan, Nina. (2014). Kontrastivna raščlamba kao postupak otkrivanja podrijetla frazema (na primjeru frazema sa zoonimskom sastavnicom) // Animalistički frazemi u slavenskim jezicima. U: Vidiović Bolt, Ivana (ur.). Zagreb: Filozofski fakultet Sveučilišta u Zagrebu: FF press, str. 1 - 14. 
Umurova, Gulnas. (2005). Was der Volksmund in einem Sprichwort verpackt...Moderne Aspekte des Sprichwortgebrauchs - anhand von Beispielen aus dem Internet. Bern: Peter Lang.

Varvaro, Alberto. (2001). Linguistica romanza. Corso introduttivo. Napoli: Liguori Editore.

Vidović Bolt, Ivana. (2011). Životinjski svijet u hrvatskoj i poljskoj frazeologiji I. Zagreb: Hrvatska sveučilišna naklada.

Vinogradov, Viktor V. (1947). Об основных типах фразеологических единиц в русском языке. U: Избранные труды. Лексикология и лексикография, Moskva: Nauka, str. $140-161$.

Walter, Harry; Mokienko, Valerij M. (2009). Nemecko-russkij slovar biblejskoj frazeologii (kriterii i principy sostavlenija) Deutsch-Russisches Wörterbuch biblischer Phraseologismen. Mit historisch-etymologischen Kommentaren. Greifswald: Universität Greifswald. Philos-Fak.

Wotjak, Barbara. (1992). Verbale Phraseolexeme im System und Text. Tübingen.

Wotjak, Barbara. (1999). Zu textuellen Vernetzungen von Phraseologismen am Beispiel von Sprachwitzen. U: Fernandez Bravo, Nicole; Behr, Irmtraud; Rozier, Claire (ur.). Phraseme und typisierte Rede. Tübingen, str. $51-62$.

Zeman, Dalibor. (2006). Zu einigen Aspekten der kontrastiven Phraseologie am Beispiel Deutsch-Tschechisch. Theoretische Prämissen und praktische Überlegungen. U: Brücken. Germanistisches Jahrbuch Tschechien - Slowakei. Neue Folge 14 (2006). Prag: Lidové noviny, str. 299 - 317.

Zuluaga, Alberto. (1980). Introducción al estudio de las expresiones fijas. Frankfurt a. M. 


\section{MREŽNI IZVORI:}

QRonline = Quartu Monica; Rossi, Elena. Dizionario dei modi di dire (Internet). URL: (https://dizionari.corriere.it/dizionario-modi-di-dire/a.shtml) (pristupljeno u kolovozu 2019.).

BFHJonline = Baza frazema hrvatskoga jezika (URL: http://frazemi.ihjj.hr) (pristupljeno u rujnu 2019.).

KBHJ = Kolokacijska baza hrvatskog jezika (URL: http://ihjj.hr/kolokacije/) (pristupljeno u travnju 2021.).

Struna - Hrvatsko strukovno nazivlje (URL: http://struna.ihjj.hr) (pristupljeno u siječnju 2021.). 


\section{ŽIVOTOPIS}

Damir Mišetić rođen je 3. travnja 1976. u Ljubuškome. Završio je osnovnu školu u Vitini. Gimnaziju je pohađao u Mostaru i u Unni (BRD) gdje je maturirao 1996. godine.

Iste godine upisuje studij talijanskoga jezika i književnosti i njemačkoga jezika $\mathrm{i}$ književnosti na Filozofskome fakultetu Sveučilišta u Zagrebu. U zimskome semestru 1999. I 2000. godine boravi na Sveučilištu Paris Lodron u Salzburgu (CEEPUS-Stipendium). Diplomirao je na Odsjeku za talijanistiku i germanistiku Filozofskog fakulteta Sveučilišta u Zagrebu 2002. godine s temom rada iz njemačke književnosti. Tijekom i nakon studija dobitnik je stipendija za stručno i znanstveno usavršavanje u Italiji (Pordenone kolovoz / rujan 2000.).

Radio je kao profesor njemačkoga i talijanskoga jezika u više osnovnih i srednjih škola te kao predavač u školama stranih jezika. Bavio se i prevođenjem. Od listopada 2013. god. uposlen je na Studiju talijanskog jezika i književnosti na Filozofskome fakultetu Sveučilišta u Mostaru.

Sudjelovao je na brojnim seminarima za profesore njemačkoga i talijanskoga jezika:

Seminar Goethe-Instituta Gesamtbosnisch-Herzegowinisches Seminar 2005. na Jahorini, 2006. na Vlašiću i 2007. na Bjelašnici.

U organizaciji Njemačkoga veleposlanstva boravio je tri tjedna u Baden-Würthembergu na Gimnaziji u Meersburgu (Program razmjene profesora) u studenome 2008. godine.

Sudjelovao je na seminaru „Progetto a sostegno dei diritti umani e del dialogo interculturale“ na Sveučilištu u Mostaru 2009. kao konsekutivni prevoditelj te na usavršavanju za profesore talijanskoga jezika u organizaciji sveučilištâ: Università degli studi di Udine e Università Cattolica di Milano, pod naslovom: "52. Laboratorio internazionale della comunicazione sociale, linguistica e letteraria" srpanj / kolovoz 2014. godine.

\section{Popis objavljenih radova}

Mišetić, Damir. (2014). Što možemo reći o budućnosti? Kriza futura I. samo (?) u talijanskome govornom jeziku. Hum 9, 11 - 12, str. $294-302$. 
Mišetić, Damir. (2015). Uporaba prijedloga in i a u suvremenome talijanskom jeziku s osvrtom na ekvivalente u hrvatskome jeziku. Mostariensia 19, 2, str. 59 - 71.

Mišetić, Damir. (2016). Fonološki prikaz hrvatskih nagovora pape Benedikta XVI. U: Kultura komuniciranja, broj 5, str. $27-41$.

Mišetić, Damir. (2018). Slijed sastavnica binoma u talijanskome i hrvatskome jeziku. Hum 13, 20, str. $308-325$.

Mišetić, Damir. (2018). Supostavna raščlamba položaja pridjevnoga atributa u suvremenome talijanskom u odnosu na suvremeni hrvatski jezik. Mostariensia 22, 2, str. $47-64$.

Budimir, Irina: Mišetić, Damir. (2020). Utjecaj ograničenja prominentnosti slogova na slijed sastavnica binoma u talijanskome i hrvatskome jeziku. U: Identiteti - kulture - jezici. Novi obzori društvenih i humanističkih znanosti. Mostar: Filozofski fakultet Sveučilišta u Mostaru, str. 64 - 77.

\section{Popis objavljenih prijevoda}

Laun, Andreas. (2000). Ljubav i partnerstvo. Split: Verbum (ISBN 953-235-035-7) (prijevod s njemačkoga na hrvatski jezik).

Tissot, Giuseppe. (2000). Umijeće kako se u duhovnome životu okoristiti vlastitim pogrješkama. Zagreb: Sav Tvoj. (ISBN 953-6471-22-1) (prijevod s talijanskoga na hrvatski jezik).

Svidercoschi, Gian Franco. (2002). Karol Wojtyla. Split: Verbum. (ISBN 978-953-235241-2) (prijevod s talijanskoga na hrvatski jezik). 


\section{Popis sudjelovanja na međunarodnim znanstveno-stručnim konferencijama}

Mišetić, Damir. (2015). Uporaba prijedloga in i a u suvremenome talijanskom jeziku (usmeno izlaganje). Konferencija Mladi znanstvenici - Znanost kao kultura neslaganja. Filozofski fakultet Sveučilišta u Mostaru, 27. 3. 2015. godine.

Mišetić, Damir. (2016). Fonološki prikaz hrvatskih nagovora pape Benedikta XVI. (usmeno izlaganje). Konferencija Mladi znanstvenici - Znanost kao kultura neslaganja. Filozofski fakultet Sveučilišta u Mostaru, 15. 4. 2016. godine.

Mišetić, Damir. (2018). Modi di dire d'origine biblica in italiano e croato (usmeno izlaganje). 4th Interdisciplinary Seminar in Romance studies: research methods in literature, textual criticism and linguistics. Masarykovo sveučilište u Brnu, 29. svibnja - 1. lipnja 2018. godine.

Mišetić, Damir. (2019). Analisi contrastiva dei binomi in italiano e croato: l'ordine degli elementi costitutivi (usmeno izlaganje). 5th Doctoral Conference in Romance Studies (RODOSZ/5). Katoličko Sveučilište Pázmány Péter u Budimpešti, 29. ožujka 2019. godine.

Budimir, Irina; Mišetić, Damir. (2019). Utjecaj ograničenja prominentnosti slogova na slijed sastavnica binoma u talijanskome i hrvatskome jeziku (usmeno izlaganje). IDENTITETI - KULTURE - JEZICI. Novi obzori društvenih i humanističkih znanosti. Filozofski fakultet Sveučilišta u Mostaru, 31. svibnja 2019. godine.

Ljubičić, Maslina; Mišetić, Damir. (2019). Struttura dei binomi lessicali in italiano e in croato (usmeno izlaganje). Convegno Internazionale "L'italianistica nel terzo milennio: le nuove sfide nelle ricerche linguistiche, letterarie e culturali - 60 anni di studi italiani all'Università 'SS Cirrilo e Metodio' di Skopje". Skoplje, 27. - 28. rujna 2019. godine.

Ljubičić, Maslina; Mišetić, Damir. (2019). Binomi lessicali con nomi propri in italiano, croato e in altre lingue europee (usmeno izlaganje). Convegno internazionale "100 anni 
di romanistica a Zagabria: tradizione, contatti, prospettive". Filozofski fakultet Sveučilišta u Zagrebu, 17. studenoga 2019. godine.

Ljubičić, Maslina; Mišetić, Damir. (2020). Kao nebo i zemlja: nekoliko biblijskih leksičkih binoma u hrvatskome i u drugim europskim jezicima (usmeno izlaganje). XXXIV. međunarodni znanstveni skup: Jezično i izvanjezično u međudjelovanju / Linguistic and extralinguistic in interaction. Filozofski fakultet Sveučilišta u Splitu i Hrvatsko društvo za primijenjenu lingvistiku. Split (online), 24. - 26. rujna 2020. godine.

Mišetić, Damir. (2021). Outside the frames: New challenges in terminology work. Dynamicity of Specialized Knowledge Categories (DIKA) and the Institute of Croatian Language and Linguistics. Zagreb (online), 5. ožujka 2021. godine.

Mišetić, Damir. (2021). Variazione dei fraseologismi nelle lingue europee alla luce delle ricerche attuali (usmeno izlaganje). Nuovi studi di fraseologia e/o paremiologia. Associazione Italiana di Fraseologia e Paremiologia in collaborazione con il Dottorato di ricerca in Scienze documentarie, linguistiche e letterarie. Sapienza Università di Roma. Rim (online), 26. - 29. svibnja 2021. godine. 